Cadernos do Programa de Pós-Graduação

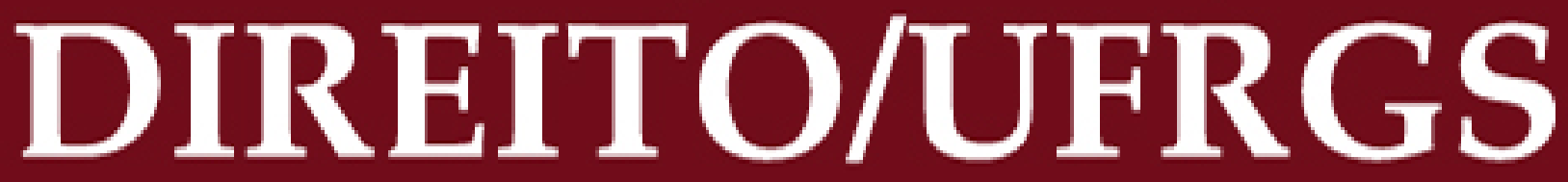

volume 8 | n.1| 2013 | seer.ufrgs.br/ppgdir

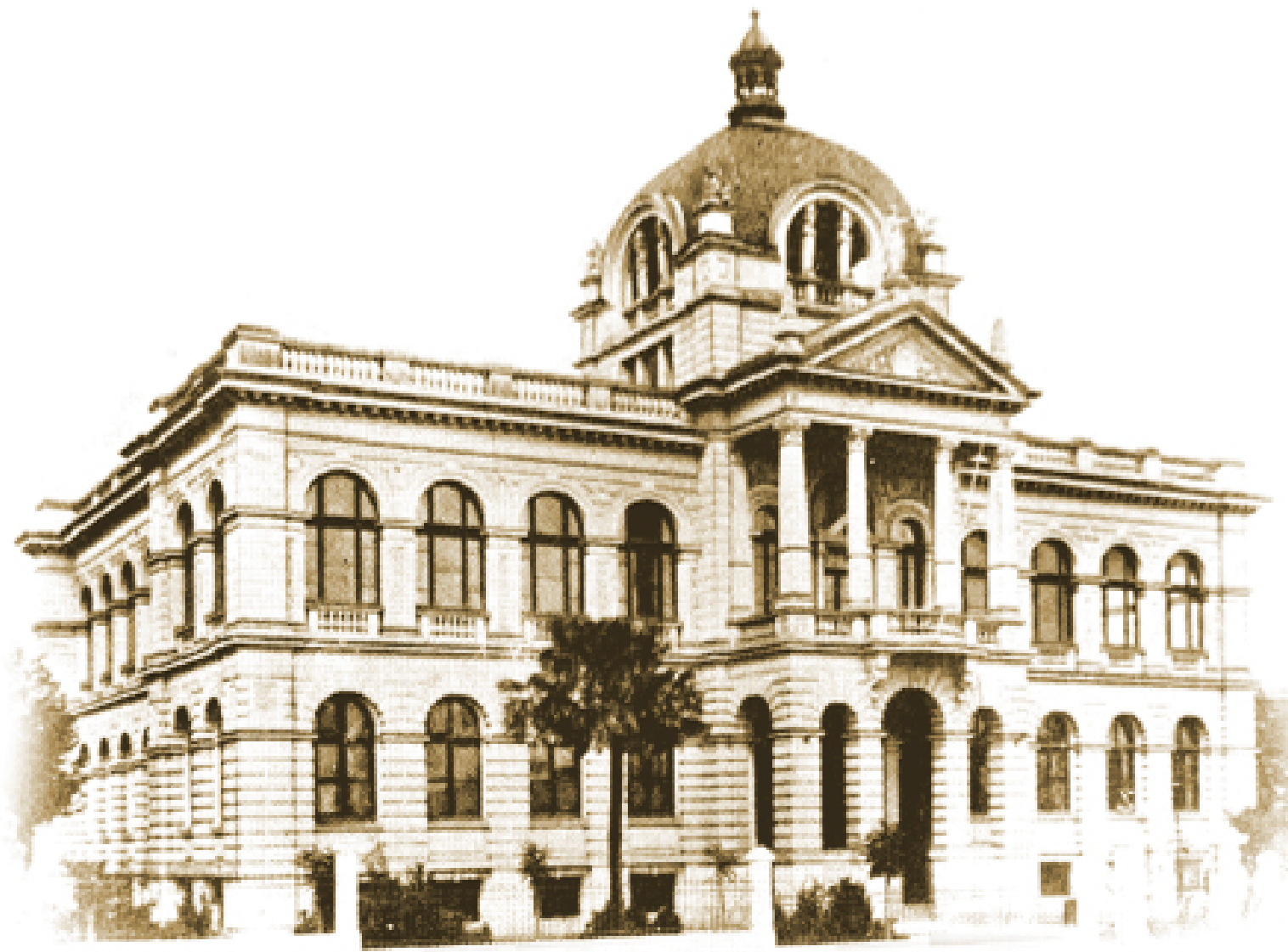


ISSN 1678-5029

E-ISSN 2317-8558

\section{Cadernos do Programa de Pós-Graduação em Direito/UFRGS}

\section{Volume VIII | Número 1 | Ano 2013}

seer.ufrgs.br/ppgdir 


\section{Universidade Federal do Rio Grande do Sul}

Reitor: Carlos Alexandre Netto

Vice-Reitor: Rui Vicente Oppermann

\section{Faculdade de Direito}

Diretor: Danilo Knijnik

Vice-Diretor: Carlos Klein Zanini

\section{Programa de Pós-Graduação eM Direito}

\section{Coordenador:}

José Alcebíades de Oliveira Júnior

\section{Coordenadora Substituta:}

Claudia Lima Marques

\section{Professores Permanentes:}

Alfredo de Jesus Dal Molin Flores

Augusto Jaeger Junior

Carlos Klein Zanini

Cesar Viterbo Matos Santolim

Cezar Saldanha Souza Junior

Claudia Lima Marques

Daniel Francisco Mitidiero

Danilo Knijnik

Fabio Costa Morosini

Humberto Bergmann Ávila

José Alcebíades de Oliveira Júnior

Leandro Amaral D. de Dorneles

Luciane Cardoso Barzotto

Luís Afonso Heck

Luis Fernando Barzotto

Luiz Felipe Silveira Difini

Martha Lucía Olivar Jimenez

Véra Maria Jacob de Fradera

Wladimir Barreto Lisboa

Professores Colaboradores:

Carlos Silveira Noronha

Rafael Da Cás Maffini

Tupinambá Pinto de Azevedo

\section{Cadernos do Programa de Pós-Graduação em Direito}

\section{Editor-Chefe:}

José Alcebíades de Oliveira Júnior

Responsável Acadêmico:

Wagner Silveira Feloniuk

\section{Secretária Executiva:}

Rosmari de Azevedo

Colaborador Executivo:

Anderson de Lima Kovalsky

\section{Conselho Editorial:}

Alvaro Sanchez Bravo (Facultad de Derecho de la Universidad de Sevilla, España)

Antonio Carlos Wolkmer (Universidade

Federal de Santa Catarina, Brasil)

Felipe Chiarello de Souza Pinto (Universidade Presbiteriana Mackenzie, Brasil)

Fredie Souza Didier Junior (Universidade

Federal da Bahia, Brasil)

Gisele Guimarães Cittadino (Pontifícia

Universidade Católica do Rio de Janeiro,

Brasil)

Luiz Guilherme Marinoni (Universidade

Federal do Paraná, Brasil)

Samyra Haydêe Dal Farra Naspolini Sanches

(Universidade Nove de Julho, Brasil)

Sérgio Cruz Arenhart (Universidade

Federal do Paraná, Brasil)

Vladmir Oliveira Silveira (Pontifícia Uni-

versidade Católica de São Paulo, Brasil)

\section{Editores-Executivos:}

Gustavo Castagna Machado

Lucas Gerhardt Gavronski

Marcos Pascotto Palermo

Wagner Silveira Feloniuk

\section{Avaliadores:}

Alfredo de Jesus Dal Molin Flores (UFRGS)

Andressa Fracaro Cavalheiro (UFRGS)

Antonio Carlos Nedel (UFRGS) 
Augusto Jaeger Junior (UFRGS)

Carlos Magno Spricigo Venerio (UFF)

Cecilia Caballero Lois (UFRJ)

Claudia Maria Barbosa (PUCPR)

Cleyson Mello (UNIPAC)

Cristiano Becker Isaia (UFSM)

Decisão Editorial (UFRGS)

Eduardo Kochenborger Scarparo (UFRGS)

Eugênia Cristina N. Ribeiro Barza (UFPE)

Eugênio Battesini (UFRGS)

Gisele Cittadino (PUC-SP)

Guilherme Boff (UFRGS)

Gustavo César Machado Cabral (FIC)

Heloísa Medeiros (CESSC)
Igor Danilevicz (UFRGS)

Joséli Fiorin Gomes (UFRGS)

Klaus Cohen Koplin (UFRGS)

Leandro do Amaral D. de Dorneles (UFRGS)

Leonardo Rocha Souza (UFRGS)

Lisiane Feiten Wingert Ody (UFRGS)

Luciane Cardoso Barzotto (UFRGS)

Lucio Antonio Machado Almeida (UFRGS)

Luiz Felipe Silveira Difini (UFRGS)

Marcelo Schenk Duque (UFRGS)

Marcos Roberto de Lima Aguirre (UFRGS)

Marta Marques Ávila (UFRGS)

Sérgio Luís Wetzel de Mattos (UFRGS)

\section{Cadernos do Programa de Pós-Graduação em Direito}

A revista Cadernos do Programa de Pós-Graduação em Direito é a publicação do Programa de Pós-Graduação em Direito da Faculdade de Direito da Universidade Federal do Rio Grande do Sul.

O Programa de Pós-Graduação em Direito da UFRGS, compreendendo o Doutorado e o Mestrado, apresenta como peculiaridade o transpasse, em suas quatro áreas de concentração (Direito Privado, Direito Público, Teoria do Direito e Direito Internacional), de uma mesma ideia nuclear, sintetizada na expressão "Fundamentos da Experiência Jurídica". Em torno dessa ideia se agrupam as três linhas de pesquisa agora propostas, a saber: Fundamentos Dogmáticos da Experiência Jurídica; Fundamentos Teórico-Filosóficos da Experiência Jurídica; e Fundamentos da Integração Jurídica.

A opção por essa linha transversal - expressa na ideia de "Fundamentos da Experiência Jurídica", a ligar as várias áreas do conhecimento jurídico e projetos institucionais e individuais de pesquisa - encontra justificativa nos planos histórico e metodológico.

Núcleo de Criação, Editoração, Revisão e Web da Gráfica da UFRGS

Acompanhamento Editorial:

Oberti do Amaral Ruschel

Capa: Débora Lima

Projeto Gráfico e Diagramação:

Glauber Winck Machado, Natasha Moreira

Revisão: Ana Santos, Felipe Raskin Cardon, Marcel Müller, Pamela Desirret Bielefeld

\section{Programa de Pós-Graduação em Direito}

Faculdade de Direito - UFRGS - Av. João

Pessoa, 80 - $2^{\circ}$ andar

Porto Alegre - RS - 90040-000

Fones: (51) 3308-3306 - 3308-3280 / Fax: (51)

3316-3987

E-mail:ppgd@ufrgs.br

Site: www.ufrgs.br/ppgd

Site da revista: www.seer.ufrgs.br/ppgdir

\section{C122 Cadernos do Programa de Pós-Graduação em Direito - PPGDir/ \\ UFRGS - vol. 8 n. 1 (2013). Porto Alegre: PPGDir/UFRGS, 2003- \\ Semestral \\ ISSN 1678-5029, E-ISSN 2317-8558 \\ 1. Direito - Periódicos I. Universidade Federal do Rio Grande do Sul





\section{Sumário}

Prefácio

A Resolução Senatorial no Controle Difuso de Constitucionalidade

Thomas Ribeiro Bergmann

A Presunção na Regra-Matriz de Incidência Tributária

Juliana Gilioli

A Constitucionalização do Direito e sua Evolução na Matéria Ambiental

Dionis Mauri Penning Blank

Princípio da Seletividade pelas Balizas da Tributação Ambiental: IPI e ICMS

Gabriel Antônio de Moraes Vieira

A (In)aplicabilidade do Instituto da Sucessão Trabalhista na Atividade Notarial e Registral Renata Hellwig Ferreira

A Materialização do Direito Internacional Privado Brasileiro: o Cancelamento da Súmula n 207 do TST Marília Zanchet Rosa

Inovações do Código Civil Brasileiro de 2002 na Disciplina do Negócio Jurídico Simulado Angela Cristina Viero 
A Expansão dos Direitos de Propriedade Industrial na União Europeia

Marcelo Schultes

Relativização da Coisa Julgada Inconstitucional em Face da Segurança Jurídica e da Justiça das Decisões Judiciais

Elis Regina Sousa Miranda

A Oralidade (e a Escrita) no Novo Código de Processo Civil Brasileiro

O Conceito do Político e a Possibilidade da Filosofia Política na Modernidade: uma Leitura Crítica de Carl Schmitt por Leo Strauss Bruno Irion Coletto

O Historicismo Jurídico do Pensamento Montesquiano em Friedrich Carl von Savigny e suas Consequentes Implicações no Materialismo Histórico Marxista Matheus Zmijevski Custódio

Hermenêutica Filosófica e Direito: Contribuições Teóricas

Regulação da Prestação de Serviços Bancários: no Limiar entre o Agravamento e a Contenção da Crise Atual no Âmbito do Mercosul 


\section{Prefácio}

O novo ciclo da revista Cadernos do Programa de PósGraduação em Direito da UFRGS - inaugurado pelo seu último número, o primeiro a ser lançado em plataforma inteiramente on-line -, continua com a presente edição a buscar patamares de excelência na pesquisa e na produção científica.

Os Cadernos do Programa de Pós-Graduação em Direito da UFRGS, portanto, procuram manter entre suas exigências que os artigos publicados possuam relevância acadêmica, interesse social, ineditismo e, de alguma forma, relação com as linhas de pesquisa do Programa de Pós-Graduação em Direito da UFRGS.

É de se ressaltar, e com isso gostaríamos já de fazer um agradecimento à comunidade acadêmica brasileira e internacional, que hoje contamos com um abalizado corpo de avaliadores, bem como com um excelente e qualificado Conselho Editorial.

Nesse quadro, destaque-se o fato de que os artigos ora publicados trazem contribuições às três linhas editoriais da revista e de pesquisa do Programa de Pós-Graduação: a dogmática, a teórico-filosófica e a da integração. São seis artigos dos ramos do Direito Público, quatro de Direito Privado, três de teoria e filosofia e um de integração.

Enfim, gostaríamos de agradecer o apoio integral de todos os nossos professores e alunos, tendo se destacado nesse número a contribuição do doutorando André Soares Oliveira. Gostaríamos de agradecer, ainda, pela continuidade e enriquecimento de nossa revista, o apoio da coordenação do Programa de Pós-Graduação em Direito da UFRGS, da Câmara de Pós- 
Graduação da UFRGS, da Pró-Reitoria de Pós-Graduação, bem como a todos os avaliadores e autores que submeteram sua produção científica à nossa revista, desejando a todos uma excelente leitura.

Prof. Dr. José Alcebíades de Oliveira Junior Coordenador PPGDir - UFRGS Editor-Chefe

Profa. Dra. Claudia Lima Marques

Coordenadora Substituta do PPGDir - UFRGS

Doutorando Gustavo Castagna Machado Doutorando Wagner Silveira Feloniuk Mestrando Lucas Gerhardt Gavronski Mestrando Marcos Pascotto Palermo Editores Colaboradores 


\section{A Resolução Senatorial no Controle Difuso de Constitucionalidade}

The Senatorial Resolution in the Diffuse Constitutional Review

Thomas Ribeiro Bergmann*

Resumo: $\mathrm{O}$ ordenamento jurídico brasileiro adota um sistema misto de controle de constitucionalidade, isto é, incorpora tanto o controle concentrado como o controle difuso de constitucionalidade. A Constituição Federal de 1988, na distribuição de competências entre os órgãos do Poder, de molde a ensejar controles recíprocos entre estes, atribui, em seu artigo 52, X, ao Senado Federal a prerrogativa de "suspender" dispositivos legais declarados contrários à Lei Maior pelo Supremo Tribunal Federal no exercício do controle de constitucionalidade difuso. Entre acordos e desacordos concernentes ao conteúdo semântico do preceito ora versado, e a despeito da posição da Corte Suprema brasileira, muita controvérsia ainda grassa na dogmática constitucional em torno da eficácia de tal dispositivo. Mostrar-se-á que a melhor solução à questão é dada quando da visualização sistemática da ordenação dos Poderes, ficando clara a relativa liberdade do Senado Federal para a suspensão com efeitos "ex nunc" do preceito legal violador da Carta Republicana.

Palavras-chave: Controle Difuso. Senado Federal. Discricionariedade Política. Inconstitucionalidade. Supremo Tribunal Federal.

Abstract: The Brazilian legal system adopts a mixed form of constitutional review, i.e., it incorporates both the concentrated and the diffuse review. The 1988 Federal Constitution, in its competence distribution among the power organs, in order to allow reciprocal

\footnotetext{
“Fundação Escola Superior do Ministério Público do Rio Grande do Sul.
} 
checks among them, ascribes, in the article 52, X, to the Federal Senate the attribution to "suspend" legal precepts declared contrary to the Constitution by the Supremo Tribunal Federal in its exercise of the diffuse constitutional review. Among agreements and disagreements concerning the semantic content of the precept now analyzed, and despite the position of the Brazilian Supreme Court, a lot of controversy still remains in the constitutional dogmatics about the legal effects of that prescription. It will be shown that the best solution to this issue is given when the systematic ordering of powers is visualized, this way becoming clear the relativity of the Senate's liberty to suspend with "ex nunc" effects the legal precept that violates the Federal Constitution.

Keywords: Diffuse Control. Federal Senate. Political Discretionality. Unconstitutionality. Supremo Tribunal Federal.

\section{Introdução}

Desde a entrada em vigor da Carta Republicana de 1988, poucos de seus dispositivos suscitaram tantas discussões na literatura constitucionalista pátria quanto o inscrito no décimo inciso do art. 52 daquela Lei Magna. Trata-se de texto normativo veiculador de uma norma-regra de relevância elevadíssima no âmbito do controle de constitucionalidade pela via da exceção e, portanto, no sistema de defesa e restauração de ordem constitucional estatuído pela Constituição Federal de 1988. Tais razões, sucintamente expostas, nos levam a crer ser de máxima importância a discussão e a clarificação de questões emergentes com a positivação da norma em comento. Isto é, na esteira das lições de Ferraz Junior, com a positivação de pontos de partida ao raciocínio dos juristas, os dogmas, com o intuito de clarificação de incertezas, novas incertezas surgem em face da necessidade de interpretação 
daqueles pontos de partida vinculantes, de tal sorte que a primitiva incerteza resta ampliada de uma forma controlada, ou seja, de modo compatível com a vinculação a normas e à pressão para decidir conflitos sociais ${ }^{1}$, daí emergindo novas questões a demandar novas soluções por parte dos juristas.

Muito se discute na doutrina constitucional pátria a respeito da interpretação mais adequada a ser dada ao inciso $X$ do artigo 52 da Lei Magna, o qual trata das diversas competências atribuídas em caráter de exclusividade ao Senado Federal, Casa representativa dos Estados-membros da federação brasileira e asseguradora da paridade entre os mencionados entes políticos.

Dentro da estrutura normativa da Constituição Federal de 1988, tal preceito se enquadra entre as normas de estabilização constitucional, porquanto consagra elemento importantíssimo para a solução de conflitos constitucionais e para a defesa da Lei Maior. ${ }^{2}$

\section{A Controvérsia e as Premissas de uma Solução}

\subsection{Considerações Iniciais}

O referido preceptivo estatui competir privativamente ao Senado Federal "suspender a execução, no todo ou em parte, de lei declarada inconstitucional por decisão definitiva do Supremo Tribunal Federal".

FERRAZ JR., Tercio Sampaio. Introdução ao Estudo do Direito. 6. ed. São Paulo: Atlas, 2008. p. 26-27.

2 SILVA, José Afonso da. Aplicabilidade das Normas Constitucionais. 8. ed. São Paulo: Malheiros, 2012. p. 180, nota 15. 
Trata-se, a rigor, de retirada da eficácia de lei - em sentido formal ou material, aí incluídos, e.g., os regimentos internos dos Tribunais, os quais, à luz do art. 96, I, “a”, da CF têm tal natureza (federal, estadual, distrital ou municipal) considerando vetusta lição de hermenêutica, consoante a qual não cabe ao intérprete diferençar onde o legislador não o faz, pelo menos não enquanto não se divisa razão suficiente para tanto, como no preceito em tela -, com efeitos erga omnes e, ao menos em uma primeira análise, ex nunc, com a parada desde então da "execução da lei declarada inconstitucional".

Celso Ribeiro Bastos ${ }^{3}$ noticia que a citada prerrogativa senatorial foi inserida no direito pátrio pela Carta de 1934, época em que o ordenamento jurídico brasileiro conhecia unicamente a arguição de inconstitucionalidade por via de defesa, com efeitos inter partes, de forma que a finalidade da faculdade de suspensão da execução da lei declarada inconstitucional era obviar os inconvenientes do controle difuso no que concerne à eficácia de suas decisões - conformadoras de normas jurídicas dotadas do atributo da generalidade, entendido este na esteira das lições de Norberto Bobbio ${ }^{4}$. Posteriormente, com a incorporação da ação direta à ordem jurídica brasileira, iniciaram-se fortes discussões a respeito da extensão de tal preceito às decisões declaratórias de inconstitucionalidade do Supremo em via principal. Entretanto, o Regimento Interno do Supremo Tribunal Federal, em seu art. 178, positiva regra restringindo a comunicação ao Senado para fins do art. 52, X, da CF, aos casos de declaração de inconstitucionalidade na via difusa. Daí restando clara

3 BASTOS, Celso Ribeiro; MARTINS, Ives Gandra da Silva. Comentários à Constituição do Brasil. 4. v. t. I. São Paulo: Saraiva, 1995. p. 178.

4 BOBBIO, Norberto. Teoria da Norma Jurídica. 5. ed. São Paulo: Edipro, 2012. p. 177. 
a função da resolução senatorial de outorga de efeitos erga omnes à decisão da Corte Maior.

Discute-se, na doutrina, quanto à obrigatoriedade discricionariedade política ou vinculação - de o Senado Federal declarar a suspensão da execução da lei nos casos de declaração de inconstitucionalidade, pelo STF, através da via de exceção. Quatro hipóteses - as quais podem se sobrepor exsurgem: (a) deveria, necessariamente, o Senado suspender, via resolução, a execução da lei declarada inconstitucional na mesma extensão em que o Supremo a considerou como tal (vinculação estrita); (b) poderia o Senado, simplesmente, não suspender a execução da lei declarada inconstitucional (discricionariedade política); (c) poderia ele suspender em parte a lei declarada inconstitucional em sua totalidade pelo STF (ainda discricionariedade política); (d) poderia o Senado declarar toda a lei inconstitucional quando o STF a declara apenas em parte.

Antes de qualquer outra consideração, importa ressaltar a possibilidade da convivência de mais de uma interpretação adequada, ou seja, o Direito, consoante ressalta Fábio Ulhoa Coelho ${ }^{5}$, pode ser objeto de dois níveis diversos do conhecimento, de tal arte que a depender do objetivo que o estudioso busca alcançar, o seu conhecimento pode ser científico - o qual demandará um juízo de veracidade, a excluir as proposições inconciliáveis - ou tecnológico - o qual busca o(s) sentido(s) possível(is) das normas, não sendo viável a busca por uma verdadeira interpretação, de forma que estas não se excluem, como ocorre no conhecimento científico, mas convivem numa harmonia própria, afigurando-se como mais

5 COELHO, Fábio Ulhoa. Curso de Direito Comercial. 16. ed. São Paulo: Saraiva, 2012. p. $45-46$. 
ou menos adequadas à aplicação do Direito, o que, por sua vez, depende do esforço argumentativo apresentado pelo intérprete. Entendimento, ademais, na mesma esteira da lição de Kelsen da relativa indeterminação do ato de aplicação do Direito, do caráter de moldura do Direito aplicável em relação ao ato de produção jurídica, e da inexistência de uma única resposta correta, tendo em vista a inexistência de um critério de Direito Positivo que enseje a escolha, ao menos em definitivo e para todos os casos, por um determinado sentido dentro da múltipla significação do texto legal. ${ }^{6}$

Destarte, importa verificar qual é a norma jurídica - produto da incidência da interpretação sobre os textos normativos, in casu, normativo-constitucionais, ou a significação extraída após a interpretação sistemática das diversas disposições constantes da ordem jurídica continente da norma ${ }^{7}$ - que exsurge como a mais consentânea com uma interpretação da Carta Republicana em sua inteireza, de modo a afigurar-se como a mais adequada para a aplicação da Constituição, ao lume do postulado - no sentido kantiano de condição de possibilidade do (adequado) conhecimento, no caso, da Lei Magna - da unidade da Constituição.

\subsection{Ilegitimidade e Usurpação de Competência}

A última das hipóteses retromencionadas deve ser descartada de plano, tendo em vista questões de absoluta incompetência e ilegitimidade, sob o prisma constitucional,

6 KELSEN, Hans. Teoria Pura do Direito. 7. ed. São Paulo: Martins Fontes, 2006. p. 388-394.

7 ÁVILA, Humberto. Teoria dos Princípios. 13. ed. São Paulo: Malheiros, 2012. p. 33. 
do Senado Federal para controlar repressivamente, da forma ora analisada, a constitucionalidade de ato normativo - da parte não apreciada e não declarada como contrária à Constituição pelo STF -, usurpando competência constitucionalmente atribuída ao Supremo. Importante, contudo, ressalvar que cabe ao Legislativo, em ordem jurídico-constitucional pátria, parcela da competência controladora repressiva da constitucionalidade, não no caso em questão, nem mesmo somente ao Senado Federal, posto que ao Congresso Nacional é atribuída a competência para sustar os atos normativos do Executivo que exorbitem do poder regulamentar - controle de constitucionalidade porque centrado em eventual gravame à legalidade (art. 5º II, CF) - ou dos limites de delegação legislativa - controle repressivo formal de constitucionalidade consoante estatuído pelo art. 49, V, da Lei Maior.

\subsection{Obrigatoriedade ou Discricionariedade?}

Quanto à obrigatoriedade de o Senado suspender a execução do ato normativo inconstitucional, é necessária a constatação de que a exegese do dispositivo supratranscrito pode levar à consideração de que ambas as conclusões são razoáveis, em uma primeira vista, e que somente uma interpretação sistemática da Carta Republicana pode levar a uma resposta constitucionalmente adequada, a qual se passa a realizar.

Manoel Gonçalves Ferreira Filho afirma tratar-se de obrigação do Senado, pois, caso contrário, este teria o "poder de convalidar ato inconstitucional, mantendo-o eficaz, o que 
repugna o nosso sistema jurídico ${ }^{8 \prime}$. Contra a asserção do autor caberia aduzir a eficácia de norma jurídica individual inter partes da decisão em controle incidental, muito embora, em reforço à sua posição e ataque à tese contrária aqui apenas exposta, seja possível pugnar favoravelmente à hodierna e crescente corrente da objetivação do controle difuso de constitucionalidade, conforme outrora fora já defendido na Corte Suprema pelo Ministro Gilmar Ferreira Mendes.

Por sua vez, Celso Bastos entende caber ao Senado, unicamente, verificar a ocorrência dos pressupostos constitucionais autorizadores da declaração de inconstitucionalidade, presentes os quais, a suspensão do ato normativo impõe-se. ${ }^{9}$

Por outro lado, Michel Temer aduz ser discrição do Senado a suspensão da execução da lei declarada inconstitucional pelo STF, podendo aquele suspendê-la ou não de acordo com o seu entendimento, pois "o simples fato de o art. $52, X$, possibilitar a suspensão total ou parcial da lei revela essa discricionariedade". ${ }^{10}$ Tal afirmação, da maneira como posta pelo autor, carece de maior fundamentação, entretanto é possível entendê-la com supedâneo nos ensinamentos de José Afonso da Silva, para quem a maioria das regras de competência da Constituição - entre as quais a regra em exame, cujo caput do dispositivo em que se encontra inserta assim está redigido: "Compete privativamente ao Senado Federal" - seriam regras permissivas, isto é, conteriam

8 FILHO, Manoel Gonçalves Ferreira. Curso de Direito Constitucional. 34. ed. São Paulo: Saraiva, 2011. p. 43.

9 BASTOS, Celso Ribeiro; MARTINS, Ives Gandra da Silva. Comentários à Constituição do Brasil. 4. v. t. I. São Paulo: Saraiva, 1995. p. 179.

10 TEMER, Michel. Elementos de Direito Constitucional. 24. ed. São Paulo: Malheiros, 2012. p. 48-49. 
simples faculdade ou autorização para o exercício do poder outorgado. ${ }^{11}$ Ademais, não é outra a lição de José Souto Maior Borges, o qual aduz que desde Forsthoff (Lehrbuch des Verwaltungsrechts, 3. ed., Beck, München, v. 1, p. 347) se sabe que toda atribuição de competência se expressa pelo modal deôntico da autorização. ${ }^{12}$

$\mathrm{O}$ autor afirma, igualmente, que as expressões "no todo" ou "em parte" são utilizadas em outros dispositivos constitucionais, como o art. 66, $\$ 1^{\circ}$, o qual possibilita ao Presidente vetar total ou parcialmente uma lei, ou seja, deixando à discrição deste a dimensão, a extensão do veto. ${ }^{13}$ Chega a afirmar Temer que tais argumentos levam à conclusão de que poderia o Senado suspender em parte ato normativo declarado inconstitucional em sua integralidade pelo Supremo, o que não coaduna com a jurisprudência deste Tribunal, já que o próprio STF, malgrado entenda ser a suspensão da execução do ato normativo faculdade discricionária do Senado Federal, sob pena de mácula à separação de Poderes, entende também que a expressão "no todo ou em parte" significa ser impossível ao Senado ampliar ou reduzir o âmbito da declaração de inconstitucionalidade exarada por ele, o órgão do Poder constitucionalmente competente para tal controle.

Efetivamente, com o exposto, a outorga do referido poder ao Senado Federal, órgão político, que, conseguintemente, decide com base em critérios políticos, leva à conclusão de que se trata de poder facultativamente utilizável - e não

\footnotetext{
${ }^{11}$ SILVA, José Afonso da. Aplicabilidade das Normas Constitucionais. 8. ed. São Paulo: Malheiros, 2012. p. 69-70.

12 Prefácio à obra de Humberto Ávila, Sistema Constitucional Tributário. 5. ed. São Paulo: Saraiva, 2012. p. 53.

13 TEMER, op. cit., p. 48-49.
} 
poder-dever - deste órgão suspender a execução do ato normativo, máxime quando se considera que o constituinte originário poderia simplesmente outorgar, à decisão exarada pelo STF em sede de controle incidental, efeitos "erga omnes", mesmo que "ex nunc", mas não o fez, preferindo conferir um poder ao Senado Federal, acrescentando pitadas a mais de controle político ao sistema de controle difuso de constitucionalidade - já enormemente político em sua feição de controle material (do conteúdo constante do descritor e do prescritor das normas jurídicas) - em nossa ordem jurídica, para decidir conforme seus critérios, que, como é cediço e demonstrado pela experiência do controle de constitucionalidade realizado por órgão político, são, como não poderiam deixar de ser, eminentemente políticos, envolvendo conveniência e oportunidade, critérios extrajurídicos, ou seja, não necessariamente correlatos aos critérios atinentes à conformidade com a Constituição.

Ademais, a abstrativização do controle difuso, como já pretendeu o Ministro Gilmar Mendes, lastreado na tese da mutação constitucional ocorrida com o art. 52, X, e na chamada transcendência da ratio decidendi, ao aproximar o controle pela via difusa do controle concentrado ${ }^{14}$, levaria à ineficácia daquele dispositivo constitucional, o que se afigura inconcebível face à constatação de que a Constituição não é composta de simples declarações sem valor ou sentido, mas de normas de eficácia jurídica plena, mesmo que mínima, conforme entendimento amplamente majoritário da doutrina constitucionalista brasileira - como se vê pelas obras de, v. g., Paulo Bonavides em seu Curso de Direito Constitucional,

${ }^{14}$ RE 197.917/SP, Rel. Min. Maurício Corrêa, 06.06.2002 (Inf. 398/STF) e HC 82959/ SP, Rel. Min. Marcos Aurélio. 23.02.2006 (Inf. 418/STF) 
Ingo Sarlet em sua Eficácia dos Direitos Fundamentais, Luís Roberto Barroso em seu O Direito Constitucional e a Efetividade de Suas Normas, entre muitos outros -, desde a obra de José Afonso da Silva aqui já citada, Aplicabilidade das Normas Constitucionais, quando se trata das comumente chamadas normas de princípio programático e de princípio institutivo ou organizativo, ou seja, daquelas classificadas como de eficácia limitada pelo referido mestre, malgrado não pareça, pelo menos no que concerne aos direitos fundamentais, ser uma classificação que se sustente hodiernamente, tendo em vista a construção jurídica de uma teoria dos princípios e de uma teoria dos direitos fundamentais que aquela pressupõe como seu alicerce, como demonstrado por Virgílio Afonso da Silva em recente obra. ${ }^{15}$ Vale dizer, não parece haver, atualmente, suporte normativo para tal tese no ordenamento jurídico-constitucional brasileiro no referente aos dispositivos consagradores de direitos fundamentais, em cuja maioria José Afonso da Silva vê normas de eficácia contida, restringível com base em reservas legais, parecendo não ser viável a subsistência de tal categoria de normas no que concerne aos direitos fundamentais, dada a restringibilidade conatural com a prescindência das chamadas reservas legais - a esses direitos na sua qualidade de princípios, inobstante se reconheça a existência de regras veiculadoras de direitos fundamentais, v. g. os incisos XXXVI, XL, XLIV, LII, entre outros do art. 5ํㅡㄹ Carta Política.

Portanto, ante a maneira como o constituinte organizou o controle no sistema difuso, por mais que possa parecer mais correta a atribuição de efeitos aptos a espraiarem-se por

${ }^{15}$ SILVA, Virgílio Afonso da. Direitos Fundamentais: conteúdo essencial, restrições e eficácia. 2. ed. São Paulo: Malheiros, 2010. 
todo o ordenamento jurídico à decisão em controle por via de exceção, ou a automatização da suspensão da execução do ato normativo pelo Supremo por razões de estabilidade das relações, segurança jurídica, politicidade das decisões do STF, guardião máximo da Lei Magna, força normativa e supremacia desta, ainda parece mais correta, por todo o exposto, a exegese referente à atuação política e discricionária do Senado Federal.

Quanto à possível melhor solução à hipótese, de lege ferenda, talvez nem mesmo a outorga de efeitos "erga omnes" à decisão em controle difuso ou a automatização da suspensão da execução do ato normativo pelo Supremo conformem a solução mais consentânea com a ordem constitucional brasileira, considerando que há casos em que o Supremo declara lei inconstitucional por diferença de um ou dois votos, o que demonstra que qualquer modificação de entendimento ou na composição dos membros do Tribunal pode levar a uma decisão oposta àquela proferida originariamente, o que leva à conclusão que tal matéria ainda precisa ser mais bem discutida e refletida dentro da ordem jurídica para que haja a segurança consentânea com uma decisão que valha para todos.

Afigura-se como uma solução possível a outorga de efeitos "erga omnes" à decisão do Supremo em controle difuso no caso do entendimento dominante quanto à constitucionalidade ou inconstitucionalidade do ato normativo ser comungado por quorum elevado dos membros do Tribunal, um quorum suficiente para carrear segurança jurídica junto de si, entendida como pacificação de entendimento naquela Corte, de forma que simples mudanças corriqueiras na sua composição, no mínimo como regra, não acarretem mudança no posicionamento dominante dentre seus Ministros. 
Já aquelas decisões que não atinjam o quorum requerido e razoável para que a decisão valha para todos terão de ser mais debatidas e pensadas pelos juristas até que se chegue a um consenso razoável, o qual levará, em processos posteriores, ao quorum necessário para que tal entendimento, agora difundido e aceito de forma mais ampla, valha para todos. Ou seja, o fato de a decisão não obter consenso suficiente entre os Ministros já mostra a necessidade de reflexão sobre a matéria. Tais decisões terão efeitos entre as partes do processo, e até que, em momento posterior, e em outra lide, confirme-se o entendimento agora amplamente predominante pelo quorum necessário à outorga de efeitos "erga omnes".

Quanto ao possível argumento de que tal problema relativo ao consenso se estenderia ao controle concentrado, apesar de não se poder negar completamente a ocorrência daquele, neste, cabe afirmar que o problema resta atenuado, tendo em vista que o próprio objeto da ação é a declaração de inconstitucionalidade do ato normativo com efeitos para todos; seus efeitos são "erga omnes" por natureza - a ação existe justamente para que o ato normativo contestado seja extirpado do sistema jurídico -, e não a resolução de questão diversa que depende da declaração de inconstitucionalidade, a qual é acessória; como as próprias designações demonstram, trata-se de ação direta, em oposição ao controle indireto que ocorre na via difusa. Igualmente, o problema da possível falta de consenso e consequente instabilidade do ordenamento sempre houve e sempre haverá em certa medida, afigurando-se até mesmo saudável em certos aspectos, já que permite a evolução e o desenvolvimento das ideias. 


\subsection{Liberdade Quanto à Extensão da Suspensão?}

Quanto à possibilidade do Senado de suspender, em parte, lei declarada inconstitucional em sua totalidade pelo STF, parece mais razoável o entendimento segundo o qual se afigura impossível ao Senado ampliar ou reduzir o âmbito da declaração de inconstitucionalidade, pois estaria ele se imiscuindo no mérito da questão, na competência constitucional do Poder Judiciário de interpretar e aplicar o Direito posto.

Quer se dizer com isso que o Senado Federal, no que concerne à extensão da abrangência de sua resolução, está totalmente vinculado à decisão de mérito proveniente da cúpula do Judiciário, não podendo fugir das raias da decisão do Supremo Tribunal.

$\mathrm{O}$ argumento de Michel Temer, acima exposto, segundo 22 o qual as expressões "no todo" ou "em parte" são utilizadas em outros dispositivos constitucionais como o art. 66, 1ํ, o qual possibilita ao Presidente vetar total ou parcialmente lei, isto é, deixando à discrição deste a extensão do veto ${ }^{16}$, levando à ilação de que haveria a mesma discrição quanto à extensão da suspensão da executoriedade, não prevalece ante a constatação de que, ao contrário do que ocorre no primeiro caso, onde não há lei perfeita, mas sim mero projeto de lei dentro de seu processo de criação e, portanto, nunca aplicado, nem aplicável a casos concretos, o segundo trata de lei já perfeita, válida - ao menos em um sentido fraco correspondente à mera existência no sistema jurídico - e potencialmente aplicável a casos concretos, dotada de eficácia jurídica e, ao menos pretensamente, social, o que acarretaria maior

16 TEMER, Michel. Elementos de Direito Constitucional. 24. ed. São Paulo: Malheiros, 2012. p. $48-49$. 
instabilidade no caso de possibilidade de suspensão apenas parcial lastreada em critérios políticos.

Entretanto, o motivo determinante para a distinção que se visa demonstrar entre as situações repousa no fato de que, no segundo dos casos, há controle de órgão competente para tal, hipótese em que, como sobredito, haveria ingerência indevida do Senado no mérito da questão, o qual cabe ao STF; já na hipótese de veto do Presidente da República, não ocorreria qualquer ingerência do tipo, de forma que se trataria apenas de controle preventivo por parte do chefe do Executivo, órgão competente para tal. Trata-se de situações distintas, as quais requerem tratamentos distintos.

\section{A Eficácia Prospectiva da Resolução Senatorial}

Ao final, cabe ainda uma rápida tomada de posição quanto a outra relevante polêmica envolvendo o preceito constitucional objeto deste estudo, qual seja, a atinente à eficácia da resolução senatorial no que diz respeito às relações jurídicas constituídas durante a vigência da norma tida por inconstitucional.

A doutrina controverte ao derredor da questão. ${ }^{17}$ Esta, por sua vez, se resume à díade possível de eficácias: ex tunc ou ex nunc.

17 Pedro Lenza, referindo-se a levantamento procedido por Clèmerson Merlin Clève, aponta como favoráveis à posição que entende haver aí mera eficácia $e x$ nunc Themístocles Cavalcanti, Oswaldo Aranha Bandeira de Mello, José Afonso da Silva, Nagib Slaibi Filho, Anna Cândida da Cunha Ferraz e Regina Macedo Nery Ferrari; de outra mão, aponta como filiados ao entendimento da eficácia $e x$ tunc Clèmerson Merlin Clève, Gilmar Ferreira Mendes, Paulo Napoleão Nogueira Silva e Marcelo Caetano. Cf. Direito Constitucional Esquematizado. 15. ed. São Paulo: Saraiva, 2011. p. 254-255. 
No entanto, não parece que o texto constitucional enseje outra interpretação senão a favorável à eficácia meramente prospectiva (ex nunc) da resolução senatorial. Isso é assim, porquanto a Carta Magna fala em suspensão da executoriedade. Ora, suspensão é um termo cujo conteúdo semântico, em Direito, é perfeitamente delimitado, contrapondo-se à significação dada pela ciência jurídica ao termo interrupção, este denotador de efeitos retroativos; aquele, de eficácia prospectiva. Ademais, é assente na doutrina que a manifestação do Senado não revoga nem anula a lei, unicamente lhe retirando a eficácia, já que a lei existiu, mesmo que nulamente; "se existiu, foi aplicada, revelou eficácia, produziu validamente seus efeitos". ${ }^{18}$ Comentando a Carta Outorgada de 1969 (Emenda Constitucional no 1, de 17 de outubro de 1969), Pontes de Miranda afirmara que a lei constitucional continua 24 eficaz "a despeito da decretação da nulidade, que é in casu, até que o Senado Federal suspenda a execução (= eficácia), no todo ou em parte, de tal regra jurídica" ${ }^{19}$

Autores que pugnam pela eficácia ex tunc normalmente baseiam-se no fato de a lei inconstitucional ser algo inexistente, natimorto, nada. ${ }^{20}$ No entanto, cabe observar que "não passa de um preconceito equivocado pretender-se que melhor se prestigia a $\mathrm{CF}$ quando se nega qualquer validade e

${ }_{18}$ SILVA, José Afonso da. Aplicabilidade das Normas Constitucionais. 8. ed. São Paulo: Malheiros, 2012. p. 158; Pontes de Miranda. Comentários à Constituição de $1967 \mathrm{com}$ a Emenda $n .1$ de 1969, t. III/621, apud SILVA, José Afonso da. Aplicabilidade das Normas Constitucionais. 8. ed. São Paulo: Malheiros, 2012. p. 158.

${ }^{19}$ Ibid., p. 158.

${ }^{20}$ Como, v.g., Alfredo Buzaid (Da Ação Direita de Declaração de Inconstitucionalidade no Direito Brasileiro) e Carmen Lúcia Antunes Rocha (Constituição e Constitucionalidade). 
eficácia à norma dita 'inconstitucional'". ${ }^{21} \mathrm{Na}$ lição irretocável de Maior Borges:

Tanto mais prestigiada estará a Carta Magna, e mais expansiva será a sua eficácia, quanto mais se considere que até a lei inconstitucional está nela prevista e regulada e lhe são constitucionalmente atribuídos efeitos, embora diversificados dos efeitos das normas conformes à $\mathrm{CF}$, sobretudo no campo da revogação. Estas normas são expulsas do sistema segundo a regra: Lex posterior derogat priori (a norma posterior revoga a anterior). A lei inconstitucional depende porém de proclamação jurisprudencial e supressão de sua eficácia pelo Senado Federal (CF, art. 52, X). Quorum especial para a decretação de inconstitucionalidade (maioria absoluta dos tribunais), alterações jurisprudenciais (inconstitucional/constitucional), circunscrição do julgado às partes da demanda, no controle difuso de constitucionalidade, são exigências do sistema para proclamar-se a inconstitucionalidade das leis. Tanto aparato não seria necessário para dizer que o nada é coisa nenhuma - é a invectiva irônica de PONTES DE MIRANDA. Tudo evidencia que a lei inconstitucional existe. (BORGES, 2012, p. 48-49).

Resta, destarte, evidente a regulamentação constitucional da lei antitética aos seus ditames e, pois, a sua existência jurídica. Logo, outra conclusão não se impõe senão aquela que confere eficácia prospectiva (ex nunc) às resoluções senatoriais previstas no art. 52, X, da Lei Maior.

\section{Considerações Finais}

Considerando a grande controvérsia ao derredor do tema, não se pretende, evidentemente, resolver a questão em um artigo científico - o que seria, ademais, deveras ingênuo -,

${ }^{21}$ BORGES, José Souto Maior. Prefácio à obra de Humberto Ávila, Sistema Constitucional Tributário. 5. ed. São Paulo: Saraiva, 2012. p. 48. 
nem estatuir uma solução definitiva - papel que não incumbe à doutrina, pois, como diria Reale, ela não se encontra em uma estrutura normativa de poder, muito embora sua contribuição à Ciência Jurídica e, conseguintemente, ao seu objeto, o Direito, seja fundamental para o aprimoramento deste último em seu papel de disciplinador das relações de intersubjetividade.

Considerando, entrementes, toda a argumentação expendida no corpo deste ensaio, não parece haver exegese para o art. 52, X, da Lei Maior, mais consentânea com o sistema constitucional pátrio senão aquela que apresenta tal norma como conformadora de uma atuação política de um órgão político - o Senado Federal -, ao qual é outorgada discricionariedade para apreciar segundo juízos de oportunidade e conveniência (extrajurídicos) se é caso, ou não, de suspender-se a eficácia de lei tanto em seu sentido formal (espécies normativas enumeradas no art. 59 do Texto Constitucional) quanto em seu sentido material, sejam de que esfera da federação, mas desde que declaradas em controle difuso de constitucionalidade, pelo Supremo Tribunal Federal. Ademais, conforme aduzido por Temer:

[...] em face do princípio federativo, que, se a matéria questionada diz respeito a confronto entre lei municipal e a Constituição Estadual, ou entre lei estadual e a Constituição Estadual, pode e deve o Tribunal de Justiça, após declarar a inconstitucionalidade, remeter essa declaração à Assembleia Legislativa, para que suspenda a execução da lei (evidentemente, nos Estados em que as Constituições confiram essa competência à Assembleia). (TEMER, 2012, p. 48).

Trata-se de lição importante ante a necessária simetria que uma federação deve manter entre suas diferentes órbitas - como incompatíveis com a Constituição Federal. 
Ademais, o equilíbrio entre os Poderes engendrado na Carta Constitucional de 1988 - considerando não haver uma separação ideal do Poder, mas, no máximo, uma separação e um equilíbrio do Poder adequados para a ordem jurídica de determinado povo, de forma que cada ordenamento constrói o seu equilíbrio entre os seus órgãos do Poder -, com a conferência de atribuições, em certa medida, seguindo a ideia clássica de Montesquieu, segundo a qual uma experiência eterna atesta que todo homem que detém o poder tende a abusar do mesmo, indo o abuso até onde encontre limites, de molde que para não ser possível abusar desse poder faz-se imperioso organizar a sociedade política de tal forma que o poder seja um freio ao poder, limitando o poder pelo próprio poder $^{22}$, de forma a incumbir ao Poder Judiciário interpretar e aplicar a lei, não parece ser possível ao Legislativo, mais especificamente ao Senado Federal, alterar para mais ou para menos a extensão da declaração de inconstitucionalidade pelo Supremo Tribunal Federal.

Pelas mesmas razões, de outra mão, parece que o mecanismo do inciso $X$ do artigo 52 da Constituição não passa de mais um instrumento de controle do poder pelo poder, do Poder Judiciário pelo Poder Legislativo, conformando o sistema de freios e contrapesos (checks and balances) próprio do sistema de equilíbrio entre os Poderes construído pelo constituinte de 1988, com o que se reforça a tese, à guisa de fechamento, da conotação política e discricionária da competência senatorial estabelecida no multicitado, e objeto deste trabalho, art. 52, X, da Carta Republicana.

${ }^{22}$ MONTESQUIEU. O Espírito das Leis. São Paulo: Martins Fontes, 2005. p. 166. 


\section{Referências}

ÁVILA, Humberto. Sistema Constitucional Tributário. 5. ed. São Paulo: Saraiva, 2012.

. Teoria dos Princípios. 13. ed. São Paulo: Malheiros, 2012.

BASTOS, Celso Ribeiro; MARTINS, Ives Gandra da Silva. Comentários à Constituição do Brasil. 4. vol. t. I. São Paulo: Saraiva, 1995.

BOBBIO, Norberto. Teoria da Norma Jurídica. 5. ed. São Paulo: Edipro, 2012.

BORGES, José Souto Maior. Prefácio à obra de Humberto Ávila. In: ÁVILA, Humberto. Sistema Constitucional Tributário. 5. ed. São Paulo: Saraiva, 2012.

COELHO, Fábio Ulhoa. Curso de Direito Comercial. 16. ed. São Paulo: Saraiva, 2012.

FERRAZ JR., Tercio Sampaio. Introdução ao Estudo do Direito. 6. ed. São Paulo: Atlas, 2008.

28 FILHO, Manoel Gonçalves Ferreira. Curso de Direito Constitucional. 34. ed. São Paulo: Saraiva, 2011.

KELSEN, Hans. Teoria Pura do Direito. 7. ed. São Paulo: Martins Fontes, 2006.

LENZA, Pedro. Direito Constitucional Esquematizado. 15. ed. São Paulo: Saraiva, 2011.

MONTESQUIEU. O Espírito das Leis. São Paulo: Martins Fontes, 2005.

SILVA, José Afonso da. Aplicabilidade das Normas Constitucionais. 8. ed. São Paulo: Malheiros, 2012.

SILVA, Virgílio Afonso da. Direitos Fundamentais: conteúdo essencial, restrições e eficácia. 2. ed. São Paulo: Malheiros, 2010.

TEMER, Michel. Elementos de Direito Constitucional. 24. ed. São Paulo: Malheiros, 2012. 


\section{A Presunção na Regra-Matriz de Incidência Tributária}

Tax Presumptions in the Matrix Rule of Tax Incidence

Juliana Gilioli*

Resumo: O presente trabalho tem por objeto o estudo da utilização das presunções nos critérios que compõem a regra-matriz de incidência tributária no sistema jurídico brasileiro, de modo a verificar sua possibilidade, bem como eventuais limites a serem observados. Para tanto, este trabalho enfrenta o tema teórico da linguagem, norma e estrutura da regra-matriz de incidência tributária e, após, analisa, ainda no plano teórico, o conceito de presunção. A partir dessas análises, verifica-se, por meio do estudo de casos, a utilização das presunções na composição da estrutura da regra-matriz de incidência tributária e com base em que critérios e dentro de que limites ela pode atuar.

Palavras-chave: Presunções. Ficções. Direito Tributário. Linguagem. Regra-matriz.

Abstract: The object of this paper is the study of the use of presumptions in the criteria that make up the matrix rule of tax incidence in the Brazilian legal system, in order to verify its possibility, as well as the limits to be observed. For this purpose, this paper faces the theoretical issue of language, norm and structure of the matrix rule of tax incidence, and then - still in a theoretical perspective examines the concept of presumption. From these analyses, this paper verifies, through case studies, the use of presumptions in the structural composition of the matrix rule of tax incidence, and based on which criteria and within which limits it can act.

Keywords: Presumptions. Fictions. Tax Law. Language. Matrix Rule.

\footnotetext{
* Pontifícia Universidade Católica do Rio Grande do Sul.
} 


\section{Introdução}

No intuito de alcançar a tributação das diferentes espécies econômicas de renda, capital e operações, o legislador desenvolve sua atividade criadora do mundo jurídico, construindo as regras jurídicas que formam o direito tributário através da linguagem em textos. Em nome da praticabilidade e eficiência da técnica arrecadatória, o legislador, muitas vezes, escolhe como elemento integrante da hipótese de incidência tributária signos econômicos ou jurídicos cuja existência ainda não é concreta no mundo fenomênico, porém há indícios de que assim será. Trata-se do uso de presunções no direito tributário.

Para fins do estudo do uso das presunções no direito tributário, mais especificamente nos critérios que informam

30 a regra-matriz de incidência tributária, em um primeiro momento situar-se-á o leitor sobre as premissas adotadas: a linguagem, a norma e a regra-matriz de incidência tributária. Premissas essas a partir das lições difundidas por Lourival Vilanova e Paulo de Barros Carvalho, base teórico-filosófica julgada apropriada para o desenvolvimento deste estudo.

Em um segundo momento, passa-se a estudar o que é a presunção, a partir de suas concepções clássicas e modernas, bem como a situando no Direito. Por fim, analisa-se a utilização das presunções nas normas tributárias, a partir das seguintes indagações: é possível a utilização de presunções em normas tributárias? Se sim, em quais critérios da regra-matriz de incidência tributária? Há limites para a utilização das presunções?

Este estudo busca responder a essas questões, através da análise de casos concretos, com base no ordenamento jurídico brasileiro, tendo em vista os princípios que o informam. 


\section{A Linguagem, a Norma e a Regra-Matriz de Incidência Tributária}

O direito é composto por um conjunto de normas, num determinado território e num preciso momento do tempo; parte-se, assim, da premissa de que se está diante de um fenômeno cultural vertido em linguagem. Dentre os diversos traços que lhe são próprios, o direito apresenta o dado da linguagem como seu integrante constitutivo. A linguagem não somente fala do objeto - que é a Ciência do Direito - como também participa de sua constituição - direito positivo.

A partir do contato com a linguagem transcrita para texto, ou seja, com o plano da expressão, verificam-se as estruturas morfológicas e gramaticais - formulações literais - pelas quais o intérprete poderá construir os conteúdos significativos - significações enquanto enunciados prescritivos - e ordená-los na forma estrutural de normas jurídicas, articulando essas entidades para formar um domínio ${ }^{1}$. Disso decorre a ilação de que conhecer o direito é, em verdade, compreendê-lo, interpretá- $\mathrm{lo}^{2}$, construindo o conteúdo, o sentido e o alcance da comunicação legislada.

1 CARVAlHO, Paulo de Barros. Direito Tributário: fundamentos jurídicos da incidência. 4. ed., rev. e atual. São Paulo: Saraiva, 2006. p. 63-64.

2 A interpretação, escreveu Eros Grau, "é um processo intelectivo através do qual, partindo de fórmulas linguísticas contidas nos textos, enunciados, preceitos, disposições, alcançamos a determinação de um conteúdo normativo. [...] Interpretar é atribuir um significado a um ou vários símbolos linguísticos escritos em um enunciado normativo. O produto do ato de interpretar é, portanto, o significado atribuído ao enunciado ou texto (preceito, disposição)" (GRAU, Eros Roberto. Ensaio e Discurso sobre a Interpretação/Aplicação do Direito. 2. ed. São Paulo: Malheiros, 2003. p. 78.). A interpretação, destarte, é meio de expressão dos conteúdos normativos das disposições, meio através do qual pesquisamos as normas contidas nas disposições. Do que diremos ser - a interpretação - uma atividade que se presta a transformar disposições (textos, enunciados) em normas. De resto, Kelsen já ensinara que a norma é uma moldura dentro da qual o aplicador pode livremente realizar seu ato de escolha para proferir a decisão que concretizará a norma aplicada (KELSEN, Hans. Teoria Pura do Direito. 4. ed. Martins Fontes: São Paulo, 1995. p. 391.) 
As leis, vistas sob o ângulo ora analisado, representam o texto na sua dimensão de veículo de prescrições jurídicas, vale dizer, são suportes materiais de linguagem e veículos introdutórios de normas jurídicas. Essas, por sua vez, são o juízo implicacional construído pelo intérprete em função da experiência no trato com esses suportes comunicacionais ${ }^{3}$. Conforme adverte Geraldo Ataliba, a lei não é norma; e embora o direito positivo se revele mediante palavras, traduzidas nas leis formais, ele consiste substancialmente em normas ${ }^{4}$.

Mantendo, assim, a lógica com a base teórico-filosófica apropriada para o desenvolvimento deste estudo, entende-se a norma jurídica como sendo uma estrutura de linguagem; mais especificamente, nas palavras de Lourival Vilanova, uma estrutura lógico-sintática de significação ${ }^{5}$. A norma jurídica, assim, enquanto comando normativo dotado de coatividade, é construída pelo intérprete como resultado do processo interpretativo que tem início na leitura dos textos de lei.

Analisando a estrutura da norma jurídica, verifica-se que ela se apresenta na forma de juízo hipotético-condicional, que, em simbolismo lógico, pode ser assim representada: $\mathrm{H} \rightarrow \mathrm{C}$ (onde $\mathrm{H}=$ hipótese; $\rightarrow=$ dever-ser interproposicional; e $\mathrm{C}=$ consequente). É por meio da hipótese normativa (antecedente) que se dá a subsunção do fato à norma. Daí a afirmação do jusfilósofo Lourival Vilanova de que o fato se torna

3 CARVAlHO, Paulo de Barros. Direito Tributário: fundamentos jurídicos da incidência. 4. ed., rev. e atual. São Paulo: Saraiva, 2006. p. 34.

4 ATALIBA, Geraldo. Hipótese de Incidência Tributária. 5. ed. São Paulo: Malheiros, 1992. p. 34.

5 VILANOVA, Lourival. Norma Jurídica - Proposição Jurídica. Revista de Direito Público, São Paulo, n. 61, p. 16, jan./mar. 1982. 
fato jurídico ${ }^{6}$ porque ingressa no universo do direito através da porta que é a hipótese ${ }^{7}$. No consequente da norma jurídica, encontra-se a proposição que estabelece uma relação entre dois ou mais sujeitos, modalizada em uma das três formas deônticas ${ }^{8}$ possíveis: obrigatório, permitido ou proibido.

A estrutura da norma jurídica tributária, ou melhor, da regra-matriz de incidência tributária - conforme denominada por Paulo de Barros Carvalho ${ }^{9}$-, segue a estrutura geral da norma jurídica com certos elementos próprios da norma tributária que se passará a analisar. Inicialmente, de forma mais ampla, pode-se dizer que sua estrutura implicacional associa a um ato ou fato lícito de possível ocorrência

6 A realidade jurídica é constituída a partir dos relatos realizados por meio de linguagem competente do direito. Ocorrido determinado evento no mundo fenomênico e havendo seu relato somente em linguagem natural, este relato constituirá somente um fato social, que integra a realidade social. Contudo, havendo o relato também em linguagem do direito, ele estará constituindo um fato jurídico que integrará, por sua vez, a realidade jurídica.

7 VILANOVA, Lourival. Estruturas Lógicas e o Sistema do Direito Positivo. São Paulo: Max Limonad, 1997. p. 89.

8 A relação de implicação deôntica é aquela na qual a verdade de uma determinada situação social, prevista por uma norma jurídica, implica, consequentemente, a verdade (nascimento) de uma relação jurídica entre sujeitos de direito. As relações de implicação deôntica são diferentes das relações de causalidade natural, visto que o direito opera no campo do dever-ser. Nesse sentido, Kelsen afirma que a conduta humana "é regulada positivamente por um ordenamento positivo, desde logo, quando a um indivíduo é prescrita a realização ou a omissão de um determinado ato. (Quando é prescrita a omissão de determinado ato, esse ato é proibido). Ser a conduta de um indivíduo prescrita por uma norma objetivamente válida é equivalente a ser indivíduo obrigado a essa conduta. [...] A mesma hipótese de regulamentação positiva se verifica também quando uma determinada conduta, que é em geral proibida, é permitida a um indivíduo por uma norma que limita o domínio de validade de outra norma que proíbe essa conduta" (KELSEN, Hans. Teoria Pura do Direito. 4. ed. Martins Fontes, São Paulo, 1995. p. 16-17.).

9 A respeito da classificação das normas tributárias ver as seguintes obras de Paulo de Barros Carvalho: CARVALHO, Paulo de Barros. Direito Tributário: fundamentos jurídicos da incidência. 4. ed., rev. e atual. São Paulo: Saraiva, 2006. p. 86-87, e CARVALHO, Paulo de Barros. Curso de Direito Tributário. 13. ed. São Paulo: Saraiva, 2005. p. 250-252. 
(hipótese tributária) uma relação jurídica que obriga um determinado sujeito passivo a recolher quantia certa aos cofres públicos (consequente) ${ }^{10}$.

Assim, para que o fato social se torne fato jurídico tributário, fazendo nascer a relação jurídica tributária, aquele fato deve conter os elementos capazes de preencher os critérios fixados minimamente pela hipótese da regra-matriz de incidência tributária: os critérios material, espacial e temporal $^{11}$.

No critério material, tem-se o núcleo do fato jurídico tributário sendo formado por um verbo pessoal e com predicação incompleta, o que significa requerer sempre um complemento, direto, indireto ou predicativo. $\mathrm{O}$ núcleo do fato jurídico consiste, em verdade, no comportamento de uma pessoa, o qual está delimitado por condições espaciais e temporais. Referidos critérios interligam o lugar e o tempo nos quais o fato jurídico tributário pode ocorrer.

Portanto, enquanto na hipótese da regra-matriz de incidência tributária encontram-se os critérios que definem os elementos que o fato social deve conter para que ocorra sua subsunção à norma, constituindo-se o fato jurídico

${ }_{10}$ Ao lado das normas tributárias da regra-matriz de incidência tributária, que disciplinam a incidência dos tributos e que chamamos de normas tributárias em sentido estrito, temos também as normas tributárias que estabelecem princípios e que não serão analisadas para fins do presente estudo.

${ }^{11}$ Não se faz necessário o critério pessoal na hipótese da regra-matriz de incidência tributária, em virtude de que a ação ou o estado previstos no critério material são necessariamente pessoais; além disso, a individualização dos sujeitos da relação é adequadamente realizada no consequente da regra-matriz. Isso porque não se dá a incidência se não houver um ser humano fazendo a subsunção e promovendo a implicação que o preceito normativo determina. As normas não incidem por força própria. Assim, requerem o ser humano como elemento intercalar, movimentando as estruturas do direito, extraindo de normas gerais e abstratas outras normas gerais e abstratas ou individuais e concretas. 
tributário, no consequente encontram-se os critérios necessários ao nascimento da relação jurídica tributária.

Os critérios que compõem o consequente da regra-matriz de incidência tributária são o pessoal e o quantitativo. $\mathrm{O}$ critério pessoal fixa o conjunto de elementos que nos aponta quem são os sujeitos ativo e passivo da relação jurídica tributária; e o critério quantitativo indica o objeto da prestação, vale dizer, faz referência às grandezas mediante as quais o legislador pretendeu dimensionar o fato jurídico tributário para a apuração do quantum pertinente ao tributo, sendo seus componentes a base de cálculo e a alíquota.

Os elementos da regra-matriz de incidência tributária, quando conjugados, permitem chegar à "unidade irredutível de manifestação do deôntico"12, capaz de indicar aos destinatários da norma jurídica dispositiva tributária o comportamento que devem adotar.

\section{A Presunção no Direito Tributário}

Em sua concepção clássica, a presunção é descrita como um processo lógico pelo qual, constatada a existência de um fato determinado, conclui-se a existência de outro fato que normalmente o acompanha. Assim, diz-se que, a partir de um fato conhecido, infere-se a ocorrência de outro fato cuja existência é desconhecida, porém provável.

No estudo da linguística no Direito, as presunções são descritas como o retrato da linguagem jurídica dirigida aos seus comunicadores como numa verdadeira atividade de

${ }^{12}$ CARVAlHO, Paulo de Barros. Direito Tributário: fundamentos jurídicos da incidência. 4. ed., rev. e atual. São Paulo: Saraiva, 2006. p. 45. 
certificação dos signos. As presunções, pois, prescrevem as diferentes formas de combinação dos vocábulos para construir unidade plena de sentido jurídico. Percebe-se a presença da linguagem como algo constitutivo da presunção e da realidade jurídica, assertiva essa que inicialmente pode causar estranheza, porém, em uma análise mais profunda, verifica-se que o sistema posto nada mais é do que um grande processo linguístico comunicacional ${ }^{13}$.

No sistema jurídico, as presunções podem ser entendidas como enunciados jurídico-prescritivos que têm sempre um quantum de indutivo; tendo em vista que são juízos dependentes da experiência, fixam suas bases no real, admitindo um fato por outro, como se fossem um só, ou os mesmos. Esses enunciados, para fins do direito tributário - e, em verdade, do direito público em geral - só serão permitidos quando expressamente autorizados em lei.

A presunção possui diversos sentidos possíveis para sua acepção ${ }^{14}$, sendo todos eles admissíveis a depender do caso concreto. Para o direito tributário, por exemplo, é possível verificar tantos significados para presunção quanto forem os pontos de vista assumidos. Fato é que a função da utilização de presunções no direito tributário é a de desempenhar papel auxiliar na busca de riqueza do contribuinte, eliminando a complexidade das proposições jurídicas, tornando-as mais precisas na tarefa de moldar a realidade ${ }^{15}$.

${ }^{13}$ HARET, Florence Cronemberger. Presunções no Direito Tributário: teoria e prática. 2010. Tese (Doutorado em Direito) - Universidade de São Paulo, São Paulo, 2010. Disponível em: <http://www.teses.usp.br/teses/disponiveis/2/2133/tde-28012011090558/es.php>. Acesso em: 7 jun. 2013.

14 Ibid.

${ }^{15}$ DE PAOLA, Leonardo Sperb. Presunções e Ficções no Direito Tributário. Belo Horizonte: Del Rey, 1997. p. 103. 
Auxiliam, também, na coibição de abusos que implicam fraude à lei, sendo utilizadas ainda para aumentar a eficácia da arrecadação.

Sobre o conceito de presunção, assim entende Gilberto Ulhôa Canto:

Na presunção toma-se como sendo a verdade de todos os casos aquilo que é a verdade da generalidade dos casos iguais, em virtude de uma lei de frequência ou de resultados conhecidos, ou em decorrência da previsão lógica do desfecho. ${ }^{16}$

As presunções podem ser relativas ou absolutas. Quando absolutas, são presunções iuris et de iure, ou seja, não admitem contestação, eliminando a apresentação de prova em contrário. Por serem absolutas, criam a certeza sobre os fatos que presumem, tendo-os como provados. Dadas como incontroversas, Iso Chaitz Scherkerkewitz considera as presunções absolutas verdadeiras ficções jurídicas ${ }^{17}$ 18. O entendimento do citado autor contraria o de Pontes de Miranda ${ }^{19}$, para quem as ficções abstraem toda consideração de probabilidade, são mais que presunções legais, ainda que absolutas, pois nada se presume, toma-se como real algo que é irreal, que não existe. Já quanto à presunção legal absoluta,

${ }^{16}$ CANTO, Gilberto de Ulhôa. Presunções no direito tributário. In: MARTINS, Ives Gandra da Silva (Coord.). Presunções no Direito Tributário. São Paulo: Resenha Tributária, 1984. p. 3.

17 SCHERKERKEWITZ, Iso Chaitz. Ficções no Direito Tributário e no Direito Penal Tributário. Rio de Janeiro: Renovar, 2002. p. 91.

${ }^{18}$ O presente trabalho tem como escopo o estudo das presunções no direito tributário, mais especificamente na regra-matriz de incidência tributária, portanto, por mais que não seja objetivo primário tratar do uso das ficções para fins do direito tributário, essa figura acaba surgindo devido a sua aparente semelhança com as presunções absolutas.

${ }^{19}$ MIRANDA, Pontes de. Tratado de Direito Privado. 4. ed. t. III. São Paulo: Revista dos Tribunais, 1983. p. 446. 
há de a lei dizê-la inatacável, pois se assim não for, há que se considerá-la relativa iuris tantum.

As presunções relativas ou iuris tantum são aquelas em relação às quais a lei presume a existência de um fato em razão da ocorrência de um outro fato. Elas prevalecem, entretanto, apenas até que aquele que não a quer ou que não se conforma com a sua determinação demonstre o contrário. São relativas porque admitem prova em contrário. Para Pontes de Miranda ${ }^{20}$, toda presunção legal é, em princípio, relativa. Para que assim não seja, a própria lei deve estabelecer a impossibilidade probatória, fazendo-a absoluta.

As ficções jurídicas são, pois, proposições jurídicas prescritivas que propositadamente criam uma verdade legal contrária à verdade fenomênica ${ }^{21}{ }^{22}$. O legislador faz, em verdade, uma valoração jurídica, dentro de uma norma legal, de um fato pré-jurídico, que acontece no mundo natural, desvinculando desse fato os seus efeitos normais ${ }^{23}$.

Quanto à semelhança de presunção absoluta e ficção, essa se dá em razão de, em ambas, ocorrer a imposição da certeza jurídica de um fato verdadeiro. A diferença é que

${ }^{20}$ Ibid., p. 448.

${ }^{21}$ FERRAGUT, Maria Rita. Presunções no Direito Tributário. São Paulo: Dialética, 2001. p. 15.

${ }^{22}$ Cristiano Carvalho, em estudo sobre as ficções no direito tributário, assevera que é raro o uso de ficções na aplicação da regra tributária, sendo mais comum a tentativa de utilização da analogia ou da interpretação extensiva, isso porque em vista do princípio da tipicidade cerrada não é possível utilizar a ficção para a aplicação da regra tributária. Salienta o autor, contudo, que isso não impede que a regra abstrata em si contenha elementos ficcionais, mas veda que o aplicador utilize a ficção para substituir algum aspecto do fato que não se subsuma a regra tributária (CARVALHO, Cristiano. Ficções Jurídicas no Direito Tributário. São Paulo: Noeses, 2008. p. 274.).

${ }^{23}$ SCHERKERKEWITZ, Iso Chaitz. Ficções no Direito Tributário e no Direito Penal Tributário. Rio de Janeiro: Renovar, 2002. p. 92. 
na presunção absoluta, através de um raciocínio lógico, se deduz a existência de um fato desconhecido a partir de um fato conhecido. Para Alfredo Augusto Becker, a lei estabelece como verdade um fato que provavelmente é verdadeiro $^{24}$, já que entre os dois fatos há uma correlação natural de existência. Na ficção, ao contrário, não há dedução de verdade porque não há raciocínio lógico. A lei, a partir de um fato certo e conhecido, estabelece como verdadeiro um fato que, também no entendimento de Alfredo Augusto Becker, com toda a certeza é falso (pois não existe, como na presunção absoluta, uma correlação natural de existência entre os dois fatos ${ }^{25}$ ).

A figura das presunções foi criada, conforme já mencionado, para, dentre outros propósitos, contornar dificuldades intransponíveis, disciplinar procedimentos construtivos relacionados com a norma e facilitar a sua aplicação, possibilitando, assim, uma maior realização da ordem jurídica, ao permitir que alguns fatos sejam conhecidos a partir da existência de outros fatos ${ }^{26}$. Assim, desde já ressalta-se que o uso de presunções - em que pese auxiliarem na busca da riqueza tributável, especialmente das pessoas jurídicas - deve ser excepcional; um instrumento jurídico que somente deve ser utilizado para combater a fraude fiscal e de acordo com o sistema constitucional ${ }^{27}$.

${ }^{24}$ BECKER, Alfredo Augusto. Teoria Geral do Direito Tributário. São Paulo: Noeses, 2007. p. 509.

25 Ibid.

${ }^{26}$ CARVAlHO, Cristiano. Ficções Jurídicas no Direito Tributário. São Paulo: Noeses, 2008. p. 187.

${ }^{27}$ FERRAGUT, Maria Rita. Presunções no Direito Tributário. São Paulo: Dialética, 2001. p. 91. 
A criação de uma realidade própria que não corresponde ao mundo dos fatos através de presunções, cujas consequências se projetam diretamente sobre os contribuintes, pode atender, nas lições de Mizabel Derzi ${ }^{28}$, ao estado de necessidade administrativa, visando ao aumento da eficiência arrecadatória, mas também pode levar a abusos, uma vez que a aparência de verdade que se estabelece coloca em xeque a certeza do Direito. A mesma autora assevera que os institutos tratados são meios a que recorre o legislador com vistas à praticabilidade, sendo, esta última, o nome que se dá a todos os meios e técnicas utilizáveis com o objetivo de tornar simples e viável a execução das leis ${ }^{29}$.

A admissão de presunções no direito tributário, entretanto, não pode ignorar os princípios constitucionais, principalmente aquele que, traduzindo a segurança jurídica do contribuinte, determina a obrigação de pagar tributo somente quando um fato do mundo real ajusta-se completamente ao fato descrito abstratamente na hipótese de incidência da regra-matriz. Ruy Barbosa Nogueira e Paulo Roberto Nogueira, em parecer dado em 1977 sobre a distribuição disfarçada de lucro, já referiam o caráter excepcional e punitivo das hipóteses previstas em lei de ficções jurídicas ou presunções legais de distribuição disfarçada de lucro em matéria tributária ${ }^{30}$.

${ }^{28}$ Entenda-se como estado de necessidade a disparidade entre a estrutura arrecadatória e o número de contribuintes, o qual é infinitamente maior. (DERZI, Misabel de Abreu Machado. Direito Tributário, Direito Penal e Tipo. São Paulo: RT, 1988. p. 267-268.)

${ }^{29}$ DERZI, Misabel de Abreu Machado. Direito Tributário, Direito Penal e Tipo. São Paulo: RT, 1988. p. 105.

${ }^{30}$ NOGUEIRA, Ruy Barbosa. Direito Tributário Aplicado e Comparado. 2. v. Rio de Janeiro: Forense, 1977. p. 115. 
Assim, uma vez que o objetivo das presunções no direito tributário é auxiliar o Estado na busca da riqueza tributável do contribuinte, é comum o legislador utilizá-las, mas nem sempre o resultado observa os ditames constitucionais. No entanto, há quem negue, com veemência, a utilização de presunções absolutas e ficções no direito tributário para a definição da hipótese de incidência. Nesse sentido, manifesta-se Ricardo Mariz de Oliveira:

As ficções jurídicas e as presunções iuris et de iure são inadmissíveis em direito tributário para definição do fato gerador, admitindo-se apenas presunções relativas iuris tantum como meios de prova da ocorrência real do fato gerador. ${ }^{31}$

As presunções legais absolutas em matéria tributária não se coadunam com o princípio da tipicidade cerrada. Alberto Xavier ${ }^{32}$ preleciona que “o fato tributário é necessariamente um fato típico; e para que revista esta natureza é indispensável que ele se ajuste, em todos os seus elementos, ao tipo abstrato descrito em lei". Conclui o autor que "a tipi cidade do fato tributário pressupõe uma descrição rigorosa de seus elementos constitutivos, cuja integral verificação é indispensável para a produção de efeitos" ${ }^{\prime 3}$.

${ }^{31}$ OLIVEIRA, Ricardo Mariz de. Presunções no direito tributário. In: MARTINS, Ives Gandra da Silva (Coord.). Presunções no Direito Tributário. São Paulo: Resenha Tributária, 1984. p. 288.

32 XAVIER, Alberto. Os Princípios da Legalidade e da Tipicidade da Tributação. São Paulo: Revista dos Tribunais, 1978. p. 87.

33 Ibid. 


\section{A Presunção na Regra-Matriz de Incidência Tributária}

Vários são os argumentos que defendem o uso das presunções em matéria tributária para fins de dificultar a evasão fiscal, com a criação de sistema que propicie maior eficiência na arrecadação de tributos ${ }^{34}$. O uso de presunções está cada vez mais comum como método normativo que facilita a positivação, arrecadação e fiscalização dos tributos. Difícil, portanto, negar a sua presença no campo tributário.

Ocorre que a utilização de presunções para compor a regra-matriz de incidência tributária pode resultar na inobservância da competência constitucionalmente fixada, dando ensejo à invasão de competência alheia ou ao alargamento não autorizado da própria competência; ou seja, pode comprometer a constitucionalidade da norma jurídica tributária. Portanto, desde já, frisa-se que o que se deve observar na utilização dessa técnica são os mandamentos fundamentais estabelecidos na Constituição Federal, como garantia ao contribuinte contra abusos fiscais por essas regras presuntivas.

Destarte, antes da aplicação das regras que contenham elementos de presunção, é necessário observar se na construção da regra-matriz de incidência o legislador observou os princípios constitucionais tributários, especialmente os da estrita legalidade, da tipicidade cerrada e da capacidade contributiva.

A hipótese de incidência tributária é a primeira parte da regra-matriz de incidência, que conota abstratamente a

34 DE PAOLA, Leonardo Sperb. Presunções e Ficções no Direito Tributário. Belo Horizonte: Del Rey, 1997. p. 98. 
ação ou estado humano relevante para o direito tributário, informando suas coordenadas espaciais e temporais. Importante frisar, por oportuno, que a técnica de isolar os critérios da regra-matriz de incidência tributária serve para fins unicamente didáticos, visto que não se quer dizer que os elementos são efetivamente desassociados uns dos outros. Em verdade, não há como se falar da hipótese de incidência da regra-matriz sem se falar do consequente. Portanto, a funcionalidade da regra matriz de incidência tributária é explicar e identificar os critérios das normas instituidoras de tributos e também verificar se estas normas estão ou não de acordo com o ordenamento jurídico.

Na hipótese de incidência da regra-matriz tributária - composta pelos critérios material, espacial e temporal verifica-se, na legislação brasileira tributária, a utilização de presunção em todos os seus critérios, ora respeitando a Constituição, ora não. No critério material, por exemplo, a presunção pode ocorrer no verbo ou no seu complemento. No caso do Imposto sobre a Renda da Pessoa Jurídica (IRPJ), o critério material é: auferir (verbo) renda e proventos de qualquer natureza (complemento). Qualquer presunção que descaracterize o conceito constitucional de auferir ou de renda maculará a regra-matriz de incidência e, por conseguinte, o tributo cobrado.

Clássico é o exemplo do lucro presumido na apuração do IRPJ. Este regime de apuração, instituído pelo Decreto-lei no 5.844/43, é facultativo aos contribuintes que se encontram dentro dos limites legais, mais especificamente àqueles que não são obrigados à apuração do IRPJ pela modalidade do 
lucro real ${ }^{35}$ ou que não estão sujeitos ao lucro arbitrado ${ }^{36}$. No lucro presumido o que ocorre é uma substituição da base de cálculo primária, que é o lucro real, para uma presumida, conforme o próprio nome sugere. Aplica-se uma alíquota (coeficiente) predeterminada sobre a receita bruta, de acordo com a atividade desempenhada pela pessoa jurídica, a fim de se obter a base de cálculo do IRPJ ${ }^{37}$.

Sendo, portanto, a materialidade do imposto auferir renda e proventos de qualquer natureza, o fato de se tributar um percentual presuntivo do lucro, cuja opção assim foi manifestada pelo contribuinte, demonstra o total descasamento da materialidade constitucional com a da regra-matriz de incidência ora estudada. Ademais, neste caso, tratase de presunção absoluta, visto que o contribuinte não pode alegar que o seu percentual de lucro foi de 5\% e não $32 \%$, por exemplo, conforme disposto na legislação. Feita a escolha pelo lucro presumido, nos termos do art. 26, caput, da Lei $\mathrm{n}^{\mathbf{o}}$ 9.430/96, constitui-se o fato jurídico presumido.

Ocorre que, em que pese a materialidade constitucional do imposto ter sido alterada pela norma infraconstitucional, trata-se, em verdade, de uma opção benéfica aos

35 As pessoas jurídicas obrigadas à apuração do IRPJ pelo lucro real estão elencadas no art. 14 da Lei no 9.718/98.

${ }^{36}$ O lucro arbitrado é circunstância excepcional, pois ocorre quando a pessoa jurídica tributada com base no lucro real não cumpre as respectivas obrigações acessórias, quando há fraude ou vícios comprometedores da idoneidade da apuração realizada, quando tiver ocorrido opção indevida pelo lucro presumido, enfim, quando não for possível apurar adequadamente o imposto com base no lucro real ou presumido. (PAULSEN, Leandro. Impostos: federais, estaduais e municipais. 4. ed. rev. e atual. Porto Alegre: Livraria do Advogado, 2008. p. 73.)

37 Reprisa-se que não há como se falar da materialidade do IRPJ e, portanto, do lucro presumido, sem se falar no critério quantitativo do consequente da regra-matriz de incidência; entretanto, fazemos referência, por ora, ao critério material e não quantitativo. 
contribuintes que possam nesse regime se enquadrar e, por tal razão, referido regime é compatível com a ordem jurídica. Caso fosse regime obrigatório e não facultativo, aí sim estaríamos diante de uma inconstitucionalidade, visto que a materialidade - lucro presumido - não se enquadra ao conceito constitucional da materialidade do imposto. Além disso, teríamos flagrante ofensa a outros princípios constitucionais, como o princípio da capacidade contributiva - no caso de o contribuinte possuir prejuízos nas suas operações, por exemplo.

A presunção no critério espacial da hipótese de incidência da regra-matriz ocorre quando a lei determina presumível o local de ocorrência do fato jurídico tributário. É o espaço físico em que a relação jurídica pode passar a existir. A presunção no critério espacial é utilizada, por exemplo, no caso das entradas simbólicas de mercadorias nos estabelecimentos, para fins de incidência do Imposto sobre Operações relativas à Circulação de Mercadorias e sobre Prestações de Serviços de Transporte Interestadual, Intermunicipal e de Comunicação (ICMS).

Primeiro insta referir que a materialidade do ICMS pressupõe a ocorrência de operações de circulação de mercadorias; tem-se, portanto, a figura mercantil e, por conseguinte, de transferência de titularidades das mercadorias. A entrada simbólica das mercadorias, por seu turno, tratada no art. 20 da Lei Complementar no 87/96 e nos regulamentos estaduais, significa que tanto a entrada quanto a saída da mercadoria será presumida pela simples transmissão contratual do bem, assumindo o lugar do estabelecimento do transmitente como elemento útil para demarcar o local da incidência do imposto. 
Desse modo, a transmissão de propriedade de mercadoria se equipara, presuntivamente, à saída, ainda quando não houver, efetivamente, a circulação de mercadoria.

Ocorre que, embora seja imaginável que a mercadoria saia do estabelecimento do transmitente, o fato é que ela não saiu. Não se trata, portanto, de uma ficção ${ }^{38}$, conforme lembra Florence. Sabe-se que para que uma mercadoria seja comercializada ela não precisa, necessariamente, circular fisicamente, bastando a circulação jurídica do bem. Nesta hipótese, vejo também como uma presunção, de acordo com os princípios do sistema jurídico tributário constitucional brasileiro.

Diferente é o caso do ICMS cobrado na modalidade de substituição tributária progressiva. Neste caso, a presunção ocorre por diversos momentos, vale dizer, tanto no antecedente como no consequente da regra-matriz de incidência tributária; nos critérios temporal (antecedente), pessoal e quantitativo (consequente).

Com efeito, o substituto tributário é a pessoa escolhida pelo legislador para figurar na relação jurídica tributária, sendo sua escolha justificada visto que está vinculado com o fato tributado, ainda que indiretamente. No caso do ICMS substituição tributária progressiva, presume-se que ocorrerão subsequentes etapas de circulação da mercadoria (critério temporal) e, por tal razão, cobra-se o imposto correspondente já do contribuinte situado no início da cadeia produtiva (critério pessoal), através de uma base de cálculo presumida (critério quantitativo).

${ }^{38}$ HARET, Florence Cronemberger. Presunções no Direito Tributário: teoria e prática. 2010. Tese (Doutorado em Direito) - Universidade de São Paulo, São Paulo, 2010. Disponível em: <http://www.teses.usp.br/teses/disponiveis/2/2133/tde-28012011090558/es.php>. Acesso em: 7 jun. 2013. 
Roque Antônio Carrazza afirma com veemência a inconstitucionalidade do ICMS cobrado pela modalidade substituição tributária progressiva ou, como prefere chamar, "para frente". Segundo o autor, há um limite lógico que foi transgredido pelo legislador, visto que somente poder-se-ia substituir pessoa certa e perfeitamente identificada, não valendo a presunção do aspecto subjetivo da regra-matriz. Segundo o autor, no caso do ICMS "para frente", como a obrigação tributária ainda não surgiu, o sujeito passivo também ainda não existe, de modo que afronta princípios constitucionais, como o da não confiscatoriedade, o da não cumulatividade e o da segurança jurídica ${ }^{39}$. Acrescenta ainda o autor que é certo que o Direito utiliza as presunções e ficções para disciplinar o comportamento das pessoas, contudo há limites para isso, dentre eles o fato de somente se tributar após a ocorrência do fato imponível. Nesse sentido, Carrazza alega a inconstitucionalidade da Emenda Constitucional no 3/1993 que acrescentou o $\S 7^{\circ}$ ao art. 150 da Constituição $\mathrm{H}^{40}$, permitindo, taxativamente, a tributação por "fato gerador ${ }^{41 "}$ presumido.

Sobre o tema, o STF proferiu decisão na ADIn no 1.851-4/AL reconhecendo a constitucionalidade da regra do $\$ 7^{\circ}$ do art. 150 da Constituição Federal. Embora parte da doutrina prevaleça sustentando a inconstitucionalidade

${ }^{39}$ CARRAZA, Roque Antônio. ICMS. 15. ed. rev. e ampl. São Paulo: Malheiros, 2011. p. 355.

40 "§ 7ำ A lei poderá atribuir a sujeito passivo de obrigação tributária a condição de responsável pelo pagamento de imposto ou contribuição, cujo fato gerador deva ocorrer posteriormente, assegurada a imediata e preferencial restituição da quantia paga, caso não se realize o fato gerador presumido."

${ }^{41}$ Fato gerador aqui entendido como fato imponível. 
completa do ICMS substituição tributária progressiva, para nós parece tema já superado. Trata-se de técnica utilizada por todos os Estados da Federação, prevista na Constituição Federal e com o assente de constitucionalidade do órgão supremo. Contudo, uma importante questão deve ser observada no que tange às presunções estabelecidas no ICMS substituição tributária "para frente": a restituição imediata dos valores recolhidos por substituição se o fato imponível não se realizar.

Sobre esse aspecto, frisa-se que a constitucionalidade do instituto está vinculada à restituição imediata dos valores recolhidos nas hipóteses em que o fato imponível não se realizar em virtude de: a) simples não realização do evento e, portanto, fato jurídico; e b) operação realizada com valor menor do que o presumido (base de cálculo do imposto). Com relação à primeira hipótese, verifica-se que os Estados mantêm, nas suas legislações internas, procedimento legal prevendo a possibilidade de restituição do ICMS substituição tributária. Contudo, no caso de a operação ser realizada com valor menor do que o presumido, ou seja, culminando em pagamento a mais do imposto, não há, hodiernamente, possibilidade de os contribuintes ressarcirem-se do valor pago a mais. Neste caso, há inconstitucionalidade em razão da ofensa constitucional ao critério quantitativo da regra-matriz de incidência tributária, em razão de não se coadunar o critério constitucional material de incidência do imposto. 


\section{Considerações Finais}

Muitas vezes, apenas com o emprego de presunções o Direito consegue disciplinar o comportamento das pessoas na vida social. As presunções servem para dar praticidade ao sistema, auxiliar na tradução para o jurídico dos fatos sociais. Ocorre que nessa "tradução" devem ser observados rigorosamente os ditames constitucionais.

Com os exemplos alhures dispostos, pode-se perceber que há presunções nos mais diversos critérios da regra-matriz de incidência tributária e que ora estão de acordo com o sistema tributário nacional e ora não. Portanto, não se está advogando contra a utilização da técnica presuntiva, pelo contrário, não se conhece um ordenamento jurídico que não utilize presunções na sua composição.

Ocorre que as presunções, independentemente de qual critério da regra-matriz estejam atingindo, devem respeitar a Constituição. Não é admissível que, em razão de presunções, um tributo atinja fora do campo da materialidade escolhida como signo de riqueza. A lei, nesse caso, não estaria instituindo uma presunção de direito, mas uma ficção jurídica, tributando aquilo que não é e que nunca poderia ser.

É imperioso, portanto, que o vínculo de causalidade entre a presunção e o fim esteja de acordo com os valores constitucionais. $\mathrm{O}$ mero argumento de facilitar a arrecadação do Fisco, em nome do princípio da praticidade, não é suficiente para aceitar que sejam empregados enunciados presuntivos inconstitucionais na formulação dos critérios da regra-matriz de incidência tributária. 


\section{Referências}

ATALIBA, Geraldo. Hipótese de Incidência Tributária. 5. ed. São Paulo: Malheiros, 1992.

BECKER, Alfredo Augusto. Teoria Geral do Direito Tributário. São Paulo: Noeses, 2007.

CANTO, Gilberto de Ulhôa. Presunções no direito tributário. In: MARTINS, Ives Gandra da Silva (Coord.). Presunções no Direito Tributário. São Paulo: Resenha Tributária, 1984. p. 1-34. (Caderno de pesquisas tributárias, 9)

CARRAZA, Roque Antônio. ICMS. 15. ed. rev. e ampl. São Paulo: Malheiros, 2011.

CARVALHO, Cristiano. Ficções Jurídicas no Direito Tributário. São Paulo: Noeses, 2008.

CARVALHO, Paulo de Barros. Curso de Direito Tributário. 13. ed. São Paulo: Saraiva, 2005.

- Direito Tributário: fundamentos jurídicos da incidência. 4. ed., rev. e atual. São Paulo: Saraiva, 2006.

DE PAOLA, Leonardo Sperb. Presunções e Ficções no Direito Tributário. Belo Horizonte: Del Rey, 1997.

DERZI, Misabel de Abreu Machado. Direito Tributário, Direito Penal e Tipo. São Paulo: RT, 1988.

FERRAGUT, Maria Rita. Presunções no Direito Tributário. São Paulo: Dialética, 2001.

GRAU, Eros Roberto. Ensaio e Discurso sobre a Interpretação/Aplicação do Direito. 2. ed. São Paulo: Malheiros, 2003.

HARET, Florence Cronemberger. Presunções no Direito Tributário: teoria e prática. 2010. Tese (Doutorado em Direito) - Universidade São Paulo, São Paulo, 2010. Disponível em: <http://www. teses.usp.br/teses/disponiveis/2/2133/tde-28012011-090558/ es.php>. Acesso em: 7 jun. 2013.

KELSEN, Hans. Teoria Pura do Direito. 4. ed. São Paulo: Martins Fontes, 1995. 
MIRANDA, Pontes de. Tratado de Direito Privado. 4. ed. t. III. São Paulo: Revista dos Tribunais, 1983.

NOGUEIRA, Ruy Barbosa. Direito tributário aplicado e comparado. 2. v. Rio de Janeiro: Forense, 1977.

OLIVEIRA, Ricardo Mariz de. Presunções no direito tributário. In: MARTINS, Ives Gandra da Silva (Coord.). Presunções no Direito Tributário. São Paulo: Resenha Tributária, 1984. p. 275-330. (Caderno de pesquisas tributárias, 9)

PAULSEN, Leandro. Impostos: federais, estaduais e municipais. 4. ed. rev. atual. Porto Alegre: Livraria do Advogado, 2008.

SCHERKERKEWITZ, Iso Chaitz. Ficções no Direito Tributário e no Direito Penal Tributário. Rio de Janeiro: Renovar, 2002.

VILANOVA, Lourival. Norma Jurídica - Proposição Jurídica. Revista de Direito Público, São Paulo, n. 61, p. 12-26, jan./mar. 1982. . Estruturas Lógicas e o Sistema do Direito Positivo. São Paulo: Max Limonad, 1997.

XAVIER, Alberto. Os princípios da legalidade e da tipicidade da tributação. São Paulo: Revista dos Tribunais, 1978.

Submissão: 10/06/2013 Aceito para Publicação: 14/08/2013 



\section{A Constitucionalização do Direito e sua Evolução na Matéria Ambiental}

The Constitutionalization of Law and its Evolution in the Environmental Theme

Dionis Mauri Penning Blank*

Resumo: A pesquisa foi desenvolvida por meio das técnicas de pesquisa bibliográfica e documental, tendo por objeto a investigação da constitucionalização do direito e sua evolução na matéria ambiental. Os objetivos deste trabalho foram apresentar como a constitucionalização do direito ocorreu, evidenciar o produto da sociedade de risco (Estado ambiental) e destacar a necessária proteção do direito ao meio ambiente. Para isso, utilizou-se o método de abordagem dedutivo e o método de procedimento monográfico. Nesse sentido, constatou-se que o direito busca novos horizontes, essencialmente fundamentados na sua constitucionalização, ou seja, na utilização de uma lei maior para garantia dos interesses gerais da sociedade por meio de uma ordem objetiva de valores.

Palavras-chave: Constitucionalização. Dignidade Humana. Estado Ambiental. Meio Ambiente. Sociedade de Risco.

Abstract: This research was developed by using the techniques of bibliographic and documentary research. Its object is the constitutionalization of law and its evolution in environmental matters. The aims of this paper were to present how the constitutionalization of law happened, to evidence the product of risk society (environmental state), and to stress the necessary protection of the environment by law. For this purpose, the deductive method of approach and the method of monographic procedure were used. In this

\footnotetext{
* Universidade Federal de Pelotas.
} 
sense, it was found that law seeks new horizons, essentially based on its constitutionalization. In other words, the use of a higher law to guarantee the general interests of society through an objective order of values.

Keywords: Constitutionalization. Human Dignity. Environmental State. Environment and Risk Society.

\section{Introdução}

O papel do direito constitucional é tornar o Estado dotado de regras que possibilitem a atuação de mecanismos políticos, administrativos e jurídicos, os quais acarretem a existência de uma verdadeira democracia. No panorama brasileiro, essa democracia ocorrerá quando forem atingidos

54 os fundamentos que sustentam a República Federativa do país e os objetivos fundamentais que ela visa a alcançar.

A globalização impôs a necessidade da determinação de um novo conceito de soberania, com perspectivas que envolvam, inclusive, a proteção ao meio ambiente. Por ora, o desafio imposto aos que lutam pela obrigação de o Estado atuar, unicamente, cumprindo a lei, é concebido como sendo o de democratizar a Constituição. Porém, democratizá-la de modo harmônico com todo o contexto, levando em consideração os efeitos e as consequências da globalização, bem como os desejos e as necessidades da cidadania.

A efetividade e a aplicabilidade da Constituição conquistaram a condição plena de normas jurídicas, dotadas de imperatividade, aptas a tutelar direta e imediatamente todas as situações que contemplam. Mais do que isso, a Constituição passa a ser o meio por intermédio do qual se leem 
e interpretam todas as normas infraconstitucionais. A Lei Fundamental e seus princípios deram novo sentido e alcance ao direito civil, ao direito processual, ao direito penal, enfim, a todos os demais ramos do direito. A efetividade e a aplicabilidade da Constituição são as bases sobre as quais se desenvolveu no Brasil uma nova interpretação constitucional.

Desse modo, o Estado é sujeito de constantes demandas sociais que exigem uma realidade orientada para o ambiente, buscando suprir as necessidades de uma sociedade repleta de carências. Passa a ser evidente o surgimento de uma sociedade produtora de riscos que afetam ou podem afetar toda a humanidade, inserindo-se a ideia da indispensável proteção do meio ambiente como um dos escopos fundamentais do Estado.

Assim, o objetivo geral deste trabalho é examinar os avanços trazidos pela Teoria da Constituição, na qual o Estado constitucional, como resultado da era moderna, superou o Estado de direito, alterando seu modelo de legalidade pelo princípio da constitucionalidade, e mostrar que, atualmente, o Estado assume novas tarefas, como a defesa do meio ambiente e a promoção da qualidade de vida, as quais têm por base fins qualitativos e substancialmente diferentes do Estado de direito e do Estado social.

Para a realização do trabalho, utilizou-se o método de abordagem dedutivo, o método de procedimento monográfico e as técnicas de pesquisa bibliográfica e documental. Foram consultados documentos, obras e artigos nacionais e internacionais com o intuito de apresentar as diversas interfaces e posições acerca da temática proposta. O trabalho está dividido em três partes, quais sejam: a constitucionalização do direito; o Estado ambiental; e a proteção constitucional do meio ambiente. 


\section{A Constitucionalização do Direito: uma Constituição de Circunstâncias}

A Teoria da Constituição vive um momento de ascensão científica e política, afastando-se da grande crise que viveu no final do século XIX e início do século $X X$, para ser efetiva e permanente na vida social, porquanto a moderna dogmática jurídica já não exterioriza na lei um sentido de perfeição, pois o protagonismo é da Constituição, com o definido papel de unificar o ordenamento jurídico no âmbito interceptativo de suas normas e de seus princípios.

$\mathrm{O}$ direito constitucional estabelece a forma dentro da qual o intérprete deverá seguir para buscar a essência do direito e da justiça, pois a Constituição instituiu um conjunto de normas que deverão orientar sua escolha entre as alternativas possíveis: princípios, fins públicos e programas de ação.

[...] o neoconstitucionalismo ou novo direito constitucional, [...], identifica um conjunto amplo de transformações ocorridas no Estado e no Direito Constitucional, em meio às quais podem ser assinalados, (i) como marco histórico, a formação do Estado Constitucional de Direito, cuja consolidação se deu ao longo das décadas finais do século XX; (ii) como marco filosófico, o pós-positivismo, com a centralidade dos direitos fundamentais e a reaproximação entre Direito e ética; e (iii) como marco teórico, o conjunto de mudanças que incluem a força normativa da Constituição, a expansão da jurisdição constitucional e o desenvolvimento de uma nova dogmática da interpretação constitucional. Desse conjunto de fenômenos resultou um processo extenso e profundo de Constitucionalização do Direito. (BARROSO, 2004, p. 38).

Assim, a Teoria da Constituição trouxe ao século XXI propostas alternativas, a fim de obstar fases de revoluções e guerras, sugerindo a construção de uma sociedade livre, justa e de um Estado democrático de direito. Foi a constitucionalização 
do direito brasileiro que, por meio dos direitos e das garantias fundamentais, estabeleceu regras e princípios explícitos ou implícitos, levando a uma reflexão dos paradigmas, em que o núcleo do Estado constitucional passou a ser a vinculação do legislador a essa nova dogmática.

Hodiernamente, o sistema jurídico parte da unidade da Constituição para aquilatar o direito e evitar contradições de valores, indicando que ele será bem-sucedido. A aplicação prática do direito, em um Estado constitucional, não se dissocia dos princípios objetivos e das regras da Lei Fundamental, que possuem incidência sobre o entendimento hermenêutico da lei.

A Constituição deixa de estabelecer somente normas de organização para disciplinar as relações jurídicas, instituindo princípios e regras que se projetam nos diversos ramos do direito. Essa redefinição da posição da Constituição na ordem jurídica brasileira está ligada ao movimento mundial que, ao fortalecer a Lei Fundamental, coloca-a como centro do sistema jurídico pela normatividade de seus princípios.

As transformações ocorridas no Estado de Direito são advindas das próprias transformações sociais rumo à democratização. Por conseguinte, o Direito Constitucional atual, em face das nuances da sociedade hodierna que apresenta por novéis estruturas políticas, culturais e sociais e do próprio refluxo do direito, agora voltado ao poder das instituições privadas e da desconstitucionalização do direito (sobretudo nos países subdesenvolvidos), não pode negar-se uma eficácia horizontal dos direitos fundamentais: são oponíveis a outros entes não estatais e não públicos, sejam indivíduos, organizações, empresas, etc. Isto acontece porque o Direito Constitucional Moderno, em verdade, desempenha uma dupla função. A primeira delas, na positivação das garantias da liberdade individual e defesa dos direitos sociais e coletivos e o seu lugar de destaque na Carta Constitucional. A segunda função, por 
seu turno, ligada ao plano objetivo, isto é: assumindo uma dimensão valorativa dos fins anunciados na Carta Constitucional assumiram uma dimensão institucional a partir da qual seu conteúdo deve funcionalizar-se para a consecução dos fins e valores constitucionalmente proclamados. (DREY, 2007, p. 69-70).

A ascensão científica e política do direito constitucional criou uma verdadeira filtragem, tendo em vista que a Constituição deixou de ser um sistema em si para dar lugar a uma nova tarefa, que é a de interpretar todos os demais ramos do direito. Esse fenômeno, a constitucionalização do direito infraconstitucional, não se perfaz apenas com a inclusão da Lei Fundamental nos diversos ramos do direito, mas, sobretudo, com a reinterpretação de seus institutos sob uma ótica constitucional.

Expandiu-se, assim, a Teoria da Constituição. Por essa nova e atual dogmática, a norma infraconstitucional é interpretada a partir da Constituição Federal, visto que ela é vinculada a uma realidade social totalmente voltada para os direitos fundamentais do cidadão. Logo, a Constituição deixa de ser um catálogo de princípios políticos para ter o encargo de definir o direito, por intermédio de sua normatividade.

A Carta de 1988, como já consignado, tem a virtude suprema de simbolizar a travessia democrática brasileira e de ter contribuído decisivamente para a consolidação do mais longo período de estabilidade política da história do país. Não é pouco. Mas não se trata, por suposto, da Constituição da nossa maturidade institucional. É a Constituição das nossas circunstâncias. Por vício e por virtude, seu texto final expressa uma heterogênea mistura de interesses legítimos de trabalhadores, classes econômicas e categorias funcionais, cumulados com paternalismos, reservas de mercado e privilégios corporativos. A euforia constituinte - saudável e inevitável após tantos anos de exclusão da sociedade civil - levou a uma Carta que, mais do que analítica, é prolixa e corporativa. 
$[\ldots]$.

Embora o fenômeno da constitucionalização do Direito, como aqui analisado, não se confunda com a presença de normas de direito infraconstitucional na Constituição, há um natural espaço de superposição entre os dois temas. Com efeito, na medida em que princípios e regras específicos de uma disciplina ascendem à Constituição, sua interação com as demais normas daquele subsistema muda de qualidade e passa a ter um caráter subordinante. Trata-se da constitucionalização das fontes do Direito naquela matéria. Tal circunstância, nem sempre desejável, interfere com os limites de atuação do legislador ordinário e com a leitura constitucional a ser empreendida pelo Judiciário em relação ao tema que foi constitucionalizado. (BARROSO, 2004, p. 45-46).

A passagem da Constituição para influenciar o direito público e o privado resulta em uma grande evolução, que foi a de considerar os direitos fundamentais como primazia do sistema jurídico, tornando, via de consequência, a Lei Fundamental mais efetiva, em todos os segmentos jurídicos. A mudança constitucional era necessária, visto que a coletividade clamava por um sistema jurídico mais atualizado, voltado às garantias dos direitos fundamentais, tendo em conta que os princípios gerais do direito não concretizavam isoladamente essa missão.

Os direitos fundamentais do homem, portanto, constituem-se bases da ordem jurídica pública e privada, como elementos objetivos. Nessa perspectiva, não há mais limites precisos que separam o direito constitucional e o direito privado, não sendo possível concebê-los como compartimentos estanques, como mundos separados, impermeáveis, governados por lógicas diferentes.

Segundo Tavares (1997, p. 98), é necessária a busca de novos critérios de racionalidade, adequados ao processo 
de inter-relação da sociedade e do Estado, dos quais podem surgir resultados normativos e que se vão projetar num exercício de responsabilidade coletiva, produzindo a evolução do próprio direito constitucional. Significa trilhar um novo rumo para o direito constitucional.

Assim, todos os dispositivos constantes da Constituição são dotados de normatividade, sendo que o papel da Teoria da Constituição passa a ser o de incrementar a força normativa da Constituição, como um todo, sem fragmentação, pois o problema fundamental em relação aos direitos do homem, hoje em dia, não é tanto o de justificá-los, mas o de protegê-los. No mesmo passo, funcionam os princípios como marco do desenvolvimento da concretização da Constituição, sendo substituída a ideia de Teoria do Estado pela de Teoria da Constituição, responsável pela constitucionalização do direito, porque as atuais Constituições estabelecem diretrizes impositivas e permanentes para o legislador.

Nessa linha de raciocínio, passa a ser inquietante a salvaguarda incorporada ao projeto jurídico e político do Estado Constitucional contemporâneo, reflexo da preocupação com o meio ambiente, instrumentalizado no Estado Socioambiental - uma espécie de novo modelo oriundo do avanço da ciência e da tecnologia -, que propiciou a generalização dos riscos aos quais está submetida a sociedade.

\section{Produto da Sociedade de Risco: o Estado Ambiental}

Conforme Molinaro (2006, p. 45), o Estado social de direito é um Estado democrático; nele o Estado não só é o responsável por dirigir o processo econômico, como tem por 
objetivo o seu desenvolvimento integral, em que se incluem o político, o social e o cultural, constitucionalmente assegurados. Ainda, ele tem por objetivo a satisfação das necessidades vitais e básicas dos cidadãos, especialmente os mais fracos, e a distribuição de bens e serviços que estimulem o alcance dos mais elevados níveis de qualidade de vida, assegurando, como conquista permanente, o direito econômico, social, cultural e ambiental, emprestando-lhes efetividade e aperfeiçoamento.

O autor citado vai além, indicando que, atualmente, já estaria superado o Estado social, quando se pensa num "Estado socioambiental e democrático de direito", centralizando-se no seu princípio nuclear: o direito fundamental à vida e a manutenção das bases que a sustentam; imperativo que só pode ocorrer num ambiente equilibrado e saudável, onde vai concretizar-se, em sua plenitude, a máxima inscrita na dignidade humana (p. 106): “[...] não estamos sós, neste 'lugar de encontro', onde somos o encontro; somos com o outro desde uma relação de reconhecimento, respeito, reciprocidade e responsabilidade".

Desse modo, Molinaro acrescenta que um tipo de Estado com estas características está comprometido com o privilegiar a existência de um "mínimo existencial ecológico", expressão material da dignidade humana que exige a vedação da degradação deste "lugar de encontro", assegurado no princípio de proibição do enfraquecimento da tutela ambiental, fundamento para a proteção da posteridade.

A construção de uma hermenêutica mais compromissada com o ser humano, como frisado anteriormente, não é apenas na proteção dos direitos fundamentais em 
face do Estado, mas no direito atual de toda a comunidade, repelindo-se qualquer ato de cunho degradante e desumano e que não lhe garanta as condições existenciais mínimas.

Temos por dignidade da pessoa humana a qualidade intrínseca e distintiva de cada ser humano que o faz merecedor do mesmo respeito e consideração por parte do Estado e da comunidade, implicando, neste sentido, um complexo de direitos e deveres fundamentais que assegurem a pessoa tanto contra todo e qualquer ato de cunho degradante e desumano, como venham a lhe garantir condições existenciais mínimas para uma vida saudável, além de propiciar e promover sua participação ativa e co-responsável nos destinos da própria existência e da vida em comunhão com os demais seres humanos. (SARLET, 1998, p. 62).

Nesse sentido, adveio a Constituição brasileira de 1988, a qual se mostra numa reação democrática a um regime autoritário e fechado. Agora dirigida ao cidadão e colocando 62 todo o aparato estatal, em todos os níveis e poderes, a serviço do homem, ela consubstancia-se na exigência de que o poder estatal seja exercido de maneira permeável às aspirações de todos. Na verdade, a Constituição da República possibilitou um rompimento com o pensamento jurídico liberal individualista aplicado no país há muito tempo. Esse raciocínio liberal equivocado teve como consequência o apego dos juristas aos códigos de direito ordinário em detrimento da validade da Constituição Federal. Isso ocorreu precipuamente com os códigos civis, valendo-se de uma pretensa liberdade da vontade absoluta, típica ainda de uma concepção liberal arcaica, que continuava a tutelar o patrimônio como elemento central do ordenamento jurídico brasileiro.

Assim sendo, a repercussão dessas alterações havidas no âmago da sociedade demonstra profundas consequências no papel do Estado e na sua relação com as transformações necessárias a uma nova teoria jurídica para os novos 
Direitos. A dinâmica desses processos políticos e, sobretudo, econômicos, em dimensão global, demonstrou-se diretamente vinculada a uma perda de poder do Estadonação Moderno e do próprio conceito clássico de soberania.

$[\ldots]$.

Uma fórmula inicial para o encaminhamento dessa nova organização é a tendência de inserção da proteção ambiental como objetivo fundamental do Estado. Isso permite o surgimento da "hipótese do Estado de Direito Ambiental", cuja finalidade consiste na defesa do ambiente e promoção da qualidade de vida. [...]. Há um estímulo à participação cidadã através de órgãos com ou sem capacidade organizativa e reivindicativa. [...] o Estado assume novas tarefas, tais como a defesa do meio ambiente e promoção da qualidade de vida que consistem em fins qualitativa e substancialmente diversos dos anteriores (Estado de Direito e Estado Social), muitas das vezes inclusive conflitantes com estes. (ROCHA; CARVALHO, 2006, p. 18-19).

A devastação do meio ambiente tem levado o Estado a repartir com a sociedade a responsabilidade pela proteção ambiental, que deixou de pertencer ao domínio exclusivamente público, passando também ao domínio privado. $\mathrm{O}$ dever de proteger o meio ambiente é cada vez mais compartilhado entre o poder público e os cidadãos. Isso implica o surgimento de um novo Estado e de uma nova cidadania, que têm plena consciência da devastação ambiental - planetária e indiscriminada - provocada pelo desenvolvimento, aspirando assim a novos valores, como a ética pela vida, o uso racional e solidário dos recursos naturais, o equilíbrio ecológico e a preservação do patrimônio genético.

Leite, Pilati e Jamundá (2005, p. 620) salientam que a teoria da sociedade de risco, traço da fase posterior ao período industrial clássico, demonstra a tomada de consciência da exaustão do modelo de produção, que estava submetido, de 
maneira permanente, ao risco de grandes prejuízos e acontecimentos desastrosos, somando-se o uso do bem ambiental de forma ilimitada, pela apropriação, expansão geográfica, mercantilização e capitalismo predatório, levando a sociedade contemporânea a situações de grande perigo.

Leite (2007, p. 136) indica que a "[...] complexidade da atual sociedade está diretamente vinculada à conformação do Estado à ficção do Estado de direito ambiental, que visa a [...] proteção do meio ambiente". O autor indica que o Estado de direito do ambiente é imaginário e marcado por abstratividade, mas destaca que seu debate exige que a reflexão, no que diz respeito à preservação do meio ambiente, não possa limitar-se apenas a Estados isolados. Aduz, ainda, que sua abstratividade não pode levar ao pensamento da inexistência de importância em sua discussão, visto que a definição de seus pressupostos levaria a uma série de patamares a serem atingidos, buscando-se uma aproximação do Estado simulado.

A discussão acerca do Estado de direito do ambiente é sintetizada em cinco funções fundamentais, nos moldes de Leite, Pilati e Jamundá (2005, p. 621), a saber: moldar formas mais adequadas para a gestão dos riscos e evitar a irresponsabilidade organizada; juridicizar instrumentos contemporâneos preventivos e precaucionais, típicos do Estado pós-social; trazer a noção, ao campo do direito ambiental, de direito integrado; buscar a formação da consciência ambiental e propiciar maior compreensão do objeto estudado.

O Estado de Direito Ambiental, dessa forma, é um conceito de cunho teórico-abstrato que abarca elementos jurídicos, sociais e políticos na busca de uma situação ambiental favorável à plena satisfação da dignidade humana e harmonia dos ecossistemas. Assim, é preciso que fique claro que as normas jurídicas são apenas uma faceta do complexo de 
realidades que se relacionam com a ideia de Estado de Direito do Ambiente.

$[\ldots]$.

A consecução do Estado de Direito Ambiental passa obrigatoriamente pela tomada de consciência global da crise ambiental e exige uma cidadania participativa, que compreende uma ação conjunta do Estado e da coletividade na proteção ambiental. Trata-se, efetivamente, de uma responsabilidade solidária e participativa, unindo de forma indissociável Estado e cidadãos na preservação do meio ambiente. Assim, para se edificar e estruturar um abstrato Estado Ambiental pressupõe-se uma democracia ambiental, amparada em uma legislação avançada que encoraje e estimule o exercício da responsabilidade solidária. (LEITE, 2007, p. 153-154).

Para a emergência do Estado e da cidadania ambientais importa ainda o reconhecimento de novos institutos e de novas garantias que propiciem respostas adequadas a esses anseios. Nesse contexto, o direito ambiental, por meio (da máxima efetividade) de seus princípios e regras, assume importância singular como viabilizador do bem-estar da sociedade que vive a crise ambiental - a sociedade contemporânea.

$\mathrm{Na}$ realidade, o Estado ambiental baseia-se numa resposta do sistema político às repercussões e modificações estruturais promovidas pela sociedade de risco. Dessa forma, deve apontar para novas formas de participação política, estabelecendo uma verdadeira democracia sustentada, a qual se mostra adequada ao desenvolvimento ambientalmente justo e duradouro. Deve-se fazer presente, mesmo num contexto de incertezas, seja por intermédio da promulgação de leis ou da emissão de atos normativos, acerca das quais não há avaliação da real eficácia.

A constitucionalização do direito ambiental representou um grande avanço e inovou em vários aspectos. 
Criou-se uma nova categoria de bens: os bens difusos, que não são particulares, nem públicos - são bens de uso comum do povo. Os sujeitos de direito são representados não só pelas presentes, mas também pelas futuras gerações. Por fim, a Constituição não somente atribui uma prerrogativa, mas também uma obrigação ao Poder Público e à coletividade de defender e preservar o meio ambiente.

De acordo com Nunes Junior (2004, p. 300), ao contrário dos direitos da primeira geração (direitos individuais), considerados como garantias do indivíduo diante do poder do Estado, e dos direitos da segunda geração (direitos sociais), caracterizados por prestações que o Estado deve ao indivíduo, o direito ao meio ambiente, como integrante dos direitos fundamentais da terceira geração (direitos difusos), consiste num direito-dever, no sentido de que a pessoa, ao mesmo tempo em que o titulariza, deve preservá-lo e defendê-lo como tal, em níveis procedimental e judicial, mediante a figura do interesse difuso. Assim, o direito ao meio ambiente diferencia-se de um direito individual ou de um direito social na medida em que a obrigação a que ele corresponde não é apenas dever jurídico do Estado, mas também do próprio particular, que é seu titular.

Por isso, a Constituição Federal de 1988 pode ser interpretada como a Constituição de um Estado Socioambiental, conforme esclarece Santilli (2005, p. 65). Há enorme preocupação do constituinte com o princípio da igualdade entre as gerações, com a utilização dos recursos naturais de forma intergeracional, com a implantação de políticas públicas para a sustentabilidade dos recursos e com um ambiente ecologicamente equilibrado, como bem de interesse público. 


\section{Proteção Constitucional do Direito Fundamental ao Meio Ambiente}

De acordo com Afonso da Silva (2007, p. 50), as Constituições anteriores a 1988 não traziam informações específicas acerca da proteção do meio ambiente, o que leva o autor a conceituar a atual Constituição de eminentemente ambientalista, visto que passou a assumir o tema em termos amplos e modernos e de maneira conjunta com fundamentos de ordem constitucional. Desse modo, diz que o direito ambiental encontra seu núcleo normativo no art. 225 dessa Constituição.

Afonso da Silva (2007, p. 53), embora trabalhe o art. 225 de forma pormenorizada, utiliza um modo didático de observá-lo, descrevê-lo e analisá-lo:

a) o direito ao meio ecologicamente equilibrado pertence a todos, incluindo aí as gerações presentes e as futuras, sejam brasileiros ou estrangeiros;

b) o dever de defender o meio ambiente e preservá-lo é imputado ao Poder Público e à coletividade;

c) o meio ambiente é um bem de uso comum do povo e essencial à sadia qualidade de vida, portanto é um bem que não está na disponibilidade particular de ninguém, nem de pessoa privada nem de pessoa pública;

d) processos ecológicos essenciais (§ 1.o, inciso I) são aqueles que asseguram as condições neces- 
sárias para uma adequada interação biológica. Prover o manejo ecológico das espécies significa lidar com as espécies de modo a conservá-las, recuperá-las, quando for o caso. Prover o manejo dos ecossistemas quer dizer cuidar do equilíbrio das relações entre a comunidade biótica e o seu habitat (mar, floresta, rio, pântanos etc.);

e) preservar a diversidade e a integridade do patrimônio genético vale dizer preservar todas as espécies, através do fator caracterizante e diferenciador da imensa quantidade de espécies vivas do país, incluindo aí todos os reinos biológicos;

f) definir espaços territoriais e seus componentes a serem especialmente protegidos significa estabelecer a delimitação de área ecologicamente relevante, onde o uso do patrimônio ali inserido ficará condicionado a disposições constantes de lei;

g) Estudo Prévio de Impacto Ambiental constitui um instrumento de prevenção de degradações irremediáveis;

h) controle da produção, comercialização e emprego de técnicas, métodos e substâncias que comportem risco para a vida, a qualidade de vida e o meio ambiente, permitindo-se, aí, a interferência do Poder Público no domínio 
privado, para impedir práticas danosas ao meio ambiente e à saúde da população;

i) promover a educação ambiental em todos os níveis de ensino e a conscientização pública para a preservação do meio ambiente constitui meio de conscientização ecológica que propiciará, no futuro, o exercício de práticas conscientemente preservacionistas;

j) proteger a fauna e a flora, do inciso VII, correlaciona-se com os incisos I e II.

É fato notório que os preceitos esculpidos no art. 225 da Constituição Federal traduzem, na concreção do seu alcance, a consagração constitucional, no sistema de direito positivo, de uma das mais expressivas prerrogativas garantidas às formações sociais contemporâneas. Tal prerrogativa, qualificada pelo caráter da metaindividualidade, consiste em reconhecer o direito de todos ao meio ambiente ecologicamente equilibrado.

Entretanto, a sociedade apresenta uma normalização da produção de riscos ecológicos, estimulada por interesses econômicos ou mesmo políticos a curto prazo. O paradigma dos sistemas sociais procede uma normalização dos riscos produzidos pela Sociedade Contemporânea [...].Essa crescente necessidade do Estado lidar com os riscos provenientes do desenvolvimento da Sociedade Industrial faz emergir, no Brasil em 1988, o denominado Estado Ecológico ou Estado Ambiental, com a constitucionalização e garantia do Direito de todos a um meio ambiente ecologicamente equilibrado (225, CF). Desse modo, pode-se apontar que o denominado Estado Ambiental consiste num processo de Ecologização das estruturas do Sistema Político em acoplamento com a dinâmica de sensibilização do Direito às irritações ecológicas (na Ecologização 
do Direito). Pode-se dizer, ainda, que os sistemas parciais procuram nas tecnologias clássicas do Estado de Direito constitucional uma última "resposta" ou "reflexão" para os conflitos de racionalidades. Portanto, a partir da constitucionalização no Brasil da matéria ambiental (art. 225, CF), o Estado (Ambiental) tem a função de integração dos vários discursos existentes na Sociedade, limitando os conflitos intersistêmicos e orientando a reflexão sistêmica sob a perspectiva moral dos Direitos fundamentais como "superdiscurso social". (ROCHA; CARVALHO, 2006, p. 19-20).

\section{O Supremo Tribunal Federal ${ }^{1}$ já firmou entendimento} no sentido de tratar-se de um direito de terceira geração ou de novíssima dimensão que acompanha, de forma subjetiva e indeterminada, todo gênero humano, o que justificaria a obrigatoriedade, do Estado e da própria coletividade, de defendê-lo e preservá-lo em proveito das presentes e futuras gerações, a fim de evitar os conflitos emanados do desres-

70 peito ao dever de solidariedade no resguardo da integridade desse bem essencial e de uso comum de todos.

Outro aspecto relevante analisado, de forma inédita, pelo STF, na mesma ocasião, consistiu no expresso reconhecimento de que o direito fundamental ao meio ambiente não encerra apenas uma perspectiva de pretensões, mas materializa, também, a proteção de valores indisponíveis e, sobretudo, de poderes de titularidade coletiva, atribuídos a toda a sociedade. Reconhece - a decisão - a consagração de um complexo conteúdo para o princípio da solidariedade, agora não mais sob uma ótica de destinatários e beneficiários, mas de titulares de poderes e prerrogativas. (AYALA, 2007, p. 372).

Cabe ressaltar que os direitos de terceira geração, ao contrário daqueles de primeira (direito civis e políticos), que compreendem o princípio da liberdade, e segunda

1 Recurso Extraordinário n. 134.297-8/SP, Primeira Turma, Rel. Min. Celso de Mello, Julgamento em 13/06/1995. 
(direitos econômicos, sociais e culturais), que compreendem o princípio da igualdade entre as gerações, materializam poderes de titularidade coletiva atribuídos, genericamente, e de modo difuso, a todos os integrantes dos agrupamentos sociais, consagrando o princípio da solidariedade e constituindo, ao lado dos chamados direitos de quarta geração (direito de desenvolvimento e direito à paz), um momento importante no processo de expansão e reconhecimento dos direitos humanos, qualificados como valores fundamentais indisponíveis.

Nesse contexto, eleva-se a ideia de que o meio ambiente constitui patrimônio público a ser necessariamente assegurado e protegido pelos organismos sociais e pelas instituições sociais, qualificando-se como encargo irrenunciável que se impõe, sempre em benefício das presentes e futuras gerações, tanto ao poder público quanto à coletividade. $\mathrm{O}$ direito à integridade do meio ambiente constitui prerrogativa jurídica de titularidade coletiva, refletindo, dentro do processo de afirmação dos direitos humanos, a expressão significativa de um poder concedido, não ao indivíduo enquanto ente singular, mas à coletividade social.

Desse modo, pode-se observar que, no contexto da ordem constitucional brasileira, e nos termos da orientação definida pelo STF, o meio ambiente é patrimônio público, não porque pertence ao Poder Público, mas porque a sua proteção (dever de todos) interessa à coletividade, e se faz em benefício das presentes e das futuras gerações, sendo essa a qualidade do bem ambiental protegida pela constituição. (AYALA, 2007, p. 373).

$\mathrm{O}$ reconhecimento de um direito de titularidade coletiva, tal como é identificado o direito ao meio ambiente ecologicamente equilibrado, constitui uma realidade em que 
se passa a reconhecer as características essenciais do bem ambiental, tal como exposta na Constituição, pesando sobre a repartição de responsabilidades no exercício de deveres, a relação estabelecida entre a sua concretização e os deveres atribuídos ao poder público e a coletividade e a titularidade compartilhada de interesses sobre o bem, alcançando inclusive as futuras gerações.

\section{Considerações Finais}

Pelo exposto, pode-se concluir que a Teoria da Constituição foi a responsável pela mudança de leitura, especialmente da legislação infraconstitucional, que passou a ser vista sob uma ótica de respeito e dignificação do ser humano, como o verdadeiro fundamento do Estado. No entanto, até se chegar ao ponto do verdadeiro equilíbrio deve-se ainda evoluir mais constitucionalmente, para se atingir uma posição de justiça social mais frequente, com a erradicação da pobreza dos povos e a estabilidade jurídica, com o respeito integral dos direitos fundamentais dos cidadãos.

Além disso, o direito ao meio ambiente (ecologicamente equilibrado) é um direito da pessoa humana, integrando a denominada terceira geração dos direitos fundamentais, e a proteção do meio ambiental é um dever do Estado e da coletividade, redundando em verdadeira solidariedade em torno de um bem comum. O Estado ambiental de direito a que tanto se aspira, assentado nos princípios da prevenção, da participação e da responsabilização e incumbido da proteção do meio ambiente e da promoção da qualidade de vida, sob os auspícios do desenvolvimento sustentável, 
pressupõe a realização de novos direitos e valores, como a educação ambiental, a democracia ambiental, a cidadania participativa e solidária e a tutela jurisdicional ambiental adequada.

Trata-se, em última análise, de garantir a dignidade da pessoa humana como valor ético-jurídico fundamental, que atrai o conteúdo de todos os direitos fundamentais do homem, desde o direito à vida. Significa dizer: aponta-se para um Estado ambiental a fim de integralizar os discursos existentes na sociedade moderna.

\section{Referências}

AYALA, Patryck de Araújo. O novo paradigma constitucional e a jurisprudência ambiental do Brasil. In: CANOTILHO, José Joaquim Gomes; LEITE, José Rubens Morato (Org.). Direito Constitucional Ambiental Brasileiro. São Paulo: Saraiva, 2007. p. 363-402

BARROSO, Luís Roberto. Neoconstitucionalismo e constitucionalização do direito. Revista da Procuradoria-Geral do Estado, Porto Alegre, v. 28, n. 60, p. 27-65, jul./dez. 2004.

DREY, Luís Carlos. A constitucionalização do direito entre o público e o privado. 2007. 164 f. Dissertação (Mestrado em Direito) - Universidade do Vale do Rio dos Sinos, São Leopoldo, 2007.

LEITE, José Rubens Morato; PILATI, Luciano Cardoso; JAMUNDÁ, Woldemar. Estado direito ambiental no Brasil. In: KISHI, Sandra Akemi Shimada; SILVA, Solange Teles da; SOARES, Inês Virgínia Prado (Org.). Desafios do direito ambiental no século XXI: estudos em homenagem a Paulo Affonso Leme Machado. São Paulo: Malheiros, 2005. p. 611-634.

LEITE, José Rubens Morato. Sociedade de risco e estado. In: CANOTILHO, José Joaquim Gomes; LEITE, José Rubens Morato (Org.). Direito constitucional ambiental brasileiro. São Paulo: Saraiva, 2007. p. 136-204. 
MOLINARO, Carlos Alberto. Racionalidade ecológica e estado socioambiental e democrático de direito. 2006. 200 f. Dissertação (Mestrado em Direito) - Pontifícia Universidade Católica do Rio Grande do Sul, Porto Alegre, 2006.

NUNES JUNIOR, Amandino Teixeira. O estado ambiental de direito. Revista de Informação Legislativa, Brasília, ano 41, n. 163, p. 295-307, jul./set. 2004.

ROCHA, Leonel Severo; CARVALHO, Delton Winter de. Policontexturalidade e direito ambiental reflexivo. Seqüência: Revista do Curso de Pós-Graduação em Direito da UFSC, Florianópolis, n. 53, p. 9-28, dez. 2006.

SANTILLI, Juliana. Socioambientalismo e novos direitos: proteção jurídica à diversidade biológica e cultural. São Paulo: Peirópolis, 2005.

SARLET, Ingo Wolfgang. Dignidade da Pessoa Humana e direitos fundamentais na Constituição Federal de 1988. Porto Alegre: Livraria do Advogado, 1998.

SILVA, José Afonso da. Direito ambiental constitucional. São Paulo:

74 Malheiros, 2007.

TAVARES, Iris Eliete Teixeira Neves Pinho. Teoria da constituição: elementos político-jurídicos, mudança constitucional, constitucionalismo e desenvolvimento jurídico. Revista de Informação Legislativa, Brasília, ano 34, n. 135, p. 91-98, jul./set. 1997.

Submissão: $15 / 11 / 2012$

Aceito para Publicação: 14/08/2013 


\section{Princípio da Seletividade pelas Balizas da Tributação Ambiental: IPI e ICMS}

\section{Principle of Selectivity for Environmental Goals of Taxation: IPI and ICMS}

Gabriel Antônio de Moraes Vieira*

Resumo: O presente artigo objetiva a análise da evolução da tutela ambiental no Direito Brasileiro e no Exterior, buscando, através do Direito Tributário, meios para auxiliar na concretização da garantia constitucional de um meio ambiente ecologicamente equilibrado. Abordar-se-ão aspectos da extrafiscalidade tributária, bem como da aplicação do princípio da seletividade. Ademais, o trabalho visa a encontrar, no IPI e no ICMS, meios para contribuir para a concretização de um meio ambiente sustentável. Finalizando o presente trabalho, propor-se-á uma nova visão acerca da aplicação do princípio da seletividade, em especial aos tributos referidos, buscando a essencialidade de um meio ambiente saudável como parâmetro para sua aplicação.

Palavras-chave: Direito Tributário Ambiental. Extrafiscalidade. Princípio da Seletividade. IPI. ICMS.

Abstract: This article aims to analyze the evolution of environmental protection in Brazilian Law and abroad, seeking, through Tax Law, means to assist in the implementation of the constitutional guarantee of an ecologically balanced environment. Non-fiscal aspects of tax shall be addressed, as well as the principle of selectivity. Moreover, this paper aims to find, in the IPI and ICMS,

* Pontifícia Universidade Católica do Rio Grande do Sul. 
means to contribute to the achievement of a sustainable environment. Concluding this paper, a new view on the implementation of the principle of selectivity will be proposed, especially on the mentioned taxes, seeking the essentiality of a healthy environment as a parameter for its application.

Keywords: Environmental Tax Law. Non-fiscal Aspects. Principle of Selectivity. IPI. ICMS.

\section{Introdução}

Notório é que, nos dias atuais, o mundo vive um momento de convergência em prol do meio ambiente e da saúde do planeta. Nessa seara, surgiu o presente trabalho, que objetiva a busca, no Direito Tributário, de meios para concretizar valores básicos, como a obtenção de um meio ambiente ecologicamente equilibrado.

O progresso é importante para a humanidade; no entanto, o processo de desenvolvimento econômico deve ter compromisso com a proteção ambiental. ${ }^{1}$

Assim, o presente trabalho fará uma busca histórica acerca da origem e da evolução da preocupação global com o meio ambiente, verificando como ela se situa no ordenamento jurídico interno e como o Direito Tributário pode ser utilizado para concretizar os fins ecológicos.

Ainda, far-se-á a verificação de como a matéria é abordada no Direito Comparado, principalmente acerca da finalidade dos tributos utilizados, se fiscais ou extrafiscais. Posto

1 TEIXEIRA, Dalvio Leite Dias; TEIXEIRA, Silvia Maria Benedetti. A constitucionalidade da tributação ambiental no Brasil. Revista da AJURIS, Associação dos Juízes do Rio Grande do Sul, Porto Alegre, v. 36, n. 115, p. 78, set. 2009. 
isto, conceituar-se-ão tais finalidades e se buscará fazer uma avaliação relativa às possibilidades de sua utilização como modo de garantir um meio ambiente sustentável.

Ademais, buscar-se-á realizar análise quanto ao princípio da seletividade e como ele se comporta no ordenamento jurídico interno, principalmente no que diz respeito aos impostos sobre produtos industrializados e sobre a circulação de mercadorias e serviços, que também serão observados e analisados.

Por fim, propor-se-á uma união entre os interesses ambientais e o Direito Tributário, verificando-se, assim, a possibilidade de, através do princípio da seletividade, contribuir para a busca por um "planeta saudável".

\section{Uma Nova Preocupação Global: o Meio Ambiente}

Inegavelmente, nas últimas décadas, houve relevante crescimento da população mundial. Inerente a tal crescimento, veio o desenvolvimento dos setores da indústria e do comércio, uma vez que, com o acréscimo populacional e uma distribuição de riquezas igualitária, a sociedade passou a ter maiores oportunidades para a aquisição de bens e serviços antes inimagináveis. ${ }^{2}$

Entretanto, a busca desenfreada por riquezas, consumo, facilidades e conforto fez com que as comunidades emergissem em séria crise de percepção que tem levado o planeta a situações ambientais insustentáveis. ${ }^{3}$

2 RODRIGUEIRO, Daniela A; SOUZA, Luiz Gustavo Alves de. Do caos à consciência ecológica: breves reflexões sobre degradação e preservação ambiental. Revista do Instituto de Pesquisas e Estudos, Bauru, Divisão Jurídica, n. 48, p. 337, jul. 2007.

3 RODRIGUEIRO, Daniela A; SOUZA, Luiz Gustavo Alves de. Op. cit., p. 337. 
Dessa forma, após período de intenso desenvolvimento, bem como a utilização incessante dos recursos naturais, a preocupação ambiental emergiu, mobilizando toda a humanidade. ${ }^{4}$ Em virtude de tamanha agressão à natureza, os ecologistas impulsionaram relevantes movimentos sociais de proteção ao meio ambiente, os quais, inevitavelmente, acabaram desembocando nas ciências jurídicas. ${ }^{5}$

O primeiro passo foi dado com a elaboração da Declaração sobre o Meio Ambiente Humano, realizada em 1992 na Conferência das Nações Unidas para o Meio Ambiente, na cidade de Estocolmo, na Suécia. Esta foi a primeira manifestação coletiva de Estados acerca da questão ambiental planetária, momento em que restou formado um órgão para democratizar o sistema internacional de decisões sobre o meio ambiente. ${ }^{6}$

Desde então, a preocupação com o meio ambiente somente se intensificou, e, após a conferência sueca, houve grande número de eventos sobre o tema, alguns deles de grande relevância, como a ECO-92, realizada na cidade do Rio de Janeiro, no Brasil, e a RIO + 10, ocorrida em Johannesburgo, na África do Sul.

Portanto, com escassos exemplos, percebe-se que o mundo está cada vez mais voltado para o meio ambiente, evoluindo a cada ano e a cada evento, mas ainda de maneira muito vagarosa.

4 ABREU, Rafaela Franco. A tributação ambiental no Brasil e nos Estados Unidos Uma análise comparativa. Publicações da Escola da AGU, Brasília, v. 4, n. 16, p. 235, mar. 2012.

5 RODRIGUEIRO, Daniela A; SOUZA, Luiz Gustavo Alves de. Op. cit., p. 342.

6 Ibidem, p. 342-343. 
Por fim, importa ressaltar que a Constituição Federal brasileira não se furtou a tal tema, deixando cristalina sua preocupação com a proteção ambiental, uma vez que passou a considerá-la como direito da pessoa humana. Para tanto, positivou tais garantias em seus artigos $170, \mathrm{VI}^{7}$, e $225^{8}$.

Destarte, tendo em vista a preocupação instigada pelo desgaste ambiental, bem como a função social do Direito Tributário, estudar-se-á como tal ramo do Direito poderá contribuir para o alcance de um meio ambiente ecologicamente equilibrado.

\section{Finalidade da Tributação Ambiental: Fiscal ou Extrafiscal}

Notório é que os tributos, de um modo geral, são entendidos como instrumentos de fiscalidade, sendo utilizados para carrear dinheiro aos cofres públicos. ${ }^{9}$ Entretanto, modernamente, vem se agregando uma nova finalidade à tributação: a extrafiscalidade..$^{10}$

7 O inciso IV assim leciona: "defesa do meio ambiente, inclusive mediante tratamento diferenciado conforme o impacto ambiental dos produtos e serviços e de seus processos de elaboração e prestação;" BRASIL. Constituição da República Federativa do Brasil de 1988. Disponível em: <http://www.planalto.gov.br/ccivil_03/ constituicao/constituicao.htm>. Acesso em: 1 jun. 2013

8 O referido dispositivo constitucional assim determina: "Art. 225. Todos têm direito ao meio ambiente ecologicamente equilibrado, bem de uso comum do povo e essencial à sadia qualidade de vida, impondo-se ao Poder Público e à coletividade o dever de defendê-lo e preservá-lo para as presentes e futuras gerações."

9 CARRAZZA, Roque Antonio; BOTTALLO, Eduardo Domingos. IPI, seletividade e alteração de alíquotas. Revista Dialética de Direito Tributário, São Paulo, n. 159, p. 107, dez. 2008.

${ }^{10}$ DIFINI, Luiz Felipe Silveira. Manual de Direito Tributário. 4. ed. atual. São Paulo: Saraiva, 2008. p. 17. 
Segundo a primeira finalidade, a tributação possui como escopo a arrecadação de verbas para os cofres públicos, objetivando regular o funcionamento do Estado. Já na segunda função - extrafiscal - o tributo não visa à arrecadação, mas sim ao exercício de atividade regulatória, utilizando o estímulo (ou o desestímulo) de determinadas atividades como forma de intervenção do Poder Público no domínio econômico. ${ }^{11}$

Quanto à tributação ambiental, observar-se-á que ambas as finalidades estão presentes; no entanto, tal ocorrência não se manifesta em proporções de igualdade, mas com a prevalência da função extrafiscal sobre a fiscal.

Tal fato ocorre porque, mais do que uma atitude isolada, a extrafiscalidade tributária é meio de tributação em prol da coletividade. Aumentam-se ou reduzem-se alíquotas com o intuito de induzir os contribuintes a fazer ou deixar de fazer alguma coisa. ${ }^{12}$

Paulo Henrique do Amaral muito bem aponta que o caráter extrafiscal prevalece na tributação ambiental, pois seu escopo é estimular as condutas não poluidoras e coibir as agressoras ao meio ambiente, ficando a natureza arrecadatória em plano secundário. ${ }^{13}$

Pode-se considerar que a defesa de um meio ambiente sadio é exemplo cristalino de defesa dos interesses difusos. Na busca por sua proteção, o Direito Tributário conta com a extrafiscalidade, podendo transformar as diversas atividades do

\footnotetext{
${ }^{11}$ Ibidem, p. 17.

${ }^{12}$ CARRAZZA, Roque Antonio. Curso de Direito Constitucional Tributário. 22. ed. São Paulo: Malheiros, 2006. p. 107-108.

13 AMARAL, Paulo Henrique. Direito Tributário Ambiental. São Paulo: Revista dos Tribunais, 2007. p. 64.
} 
Direito em instrumentos que promovam atividades econômicas ambientalmente sustentáveis. ${ }^{14}$

Nessa seara, observa-se que o Direito Tributário deve ser entendido não somente como área para arrecadação e custeio dos gastos do Estado, mas, principalmente, como meio de defesa dos interesses da sociedade, entre eles um meio ambiente sustentável. ${ }^{15}$

Em análise da extrafiscalidade nos tributos ambientais, adere-se à tese apresentada por Caliendo, que aponta para a existência de três diretrizes: $1^{\underline{a}}$ ) tratamento diferenciado às atividades poluidoras, considerando-se substantiva diferença entre estas e as demais atividades econômicas, uma vez que se trata de justiça distributiva; $2^{a}$ ) tratamento adequado visando ao bem comum, correlacionando o interesse privado e a sua contribuição para a manutenção de uma sociedade ambientalmente saudável; e $3^{2}$ ) sanção em caso de desequilíbrio gerado pela conduta poluidora. ${ }^{16}$

Em suma, o doutrinador demonstra que a extrafiscalidade poderá se relacionar com o Direito Tributário de maneira direta, indireta ou repressiva. No primeiro caso, há uma preocupação de onerar aquelas atividades prejudiciais ao meio ambiente. Já na tributação indireta, o Estado utiliza-se da tributação como meio de defesa àquelas atividades cuidadosas com a sustentabilidade, seja através da redução de alíquotas, seja por concessão de benefícios e isenções. Por

${ }^{14}$ VIEIRA, Andréia Costa. O direito humano ao meio ambiente e a tributação ambiental: água e ar: mecanismos nacionais e internacionais. Fórum de Direito Urbano e Ambiental, Belo Horizonte, v. 9, n. 53, p. 18-19, set./out. 2010.

${ }^{15}$ VIEIRA, Andréia Costa. Op. cit., p. 18-26.

${ }^{16}$ CALIENDO, Paulo. Tributação e mercado de carbono. In: TORRES, Heleno Taveira (Org.). Direito Tributário Ambiental. São Paulo: Malheiros, 2005. p. 876. 
fim, surge a modalidade repressiva, a qual visa a reparar os danos já causados ao meio ambiente.

Entende-se como mais adequado que o presente artigo fique adstrito tão somente às duas primeiras modalidades, uma vez que as atividades repressivas, por serem exemplos claros de sanção por ato ilícito, não são consideradas tributo pelo ordenamento jurídico pátrio, conforme ensina o artigo

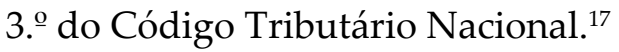

\subsection{Princípio da Seletividade}

Conforme entendimento de Luiz Felipe Silveira Difini, o princípio da seletividade é modo de adequação do princípio da capacidade contributiva. Para o doutrinador, a seletividade "significa taxar com alíquotas mais altas os produtos de consumo supérfluo ou não essencial e de forma reduzida aqueles produtos tidos como essenciais ao consumo da população, especialmente aquela de menor capacidade econômica" ${ }^{18}$

Observa-se que o intuito da aplicação do princípio da seletividade é adequar os produtos à vida do maior número de habitantes do país. Com isso, as mercadorias essenciais serão tratadas com favorecimento tributário e ofertadas ao maior número de pessoas. Já as mercadorias consideradas supérfluas devem ser taxadas com maior

\footnotetext{
${ }^{17}$ O referido dispositivo assim leciona: "Art. 3. - Tributo é toda prestação pecuniária compulsória, em moeda ou cujo valor nela se possa exprimir, que não constitua sanção de ato ilícito, instituída em lei e cobrada mediante atividade administrativa plenamente vinculada". BRASIL. Código Tributário Nacional. Disponível em: <http://www.planalto.gov.br/ccivil_03/leis/15172.htm>. Acesso em: 2 jun. 2013.

${ }^{18}$ DIFINI, Luiz Felipe Silveira. Op. cit., p. 90.
} 
rigor, uma vez que não se trata de bens inerentes à sobrevivência e ao bem-estar humano. ${ }^{19}$

Cumpre referir que a Constituição Federal não aponta quais produtos, mercadorias ou serviços são essenciais à sociedade, no entanto podem-se considerar essenciais aqueles produtos consumidos por toda a população. ${ }^{20}$ Já os supérfluos são consumidos somente por aquelas pessoas que, já tendo satisfeito suas necessidades básicas, possuem recursos para suprir outros custos. ${ }^{21}$

Importa ressaltar que, muitas vezes, são considerados produtos de primeira necessidade somente aqueles como alimentação, vestuário, medicamentos e outros. No entanto, conforme muito bem exposto por Bottallo, o alcance do princípio da seletividade não se esgota nisto. ${ }^{22}$

Para o autor, todos aqueles produtos afinados com a proteção ambiental devem ser tributados minimamente, ou não tributados. Assim, colocar-se-iam sob a salvaguarda da seletividade os produtos por ele denominados "ecologicamente corretos", expressão adotada com euforia no presente trabalho.

Insta ressaltar que a aplicação da seletividade se dá em virtude da necessidade, fator de regulação do mínimo existencial. Visa, portanto, a garantir à humanidade os meios

${ }^{19}$ BALEEIRO, Aliomar. Direito Tributário Brasileiro. 7. ed. Rio de Janeiro: Forense, 1975. p. 188.

${ }^{20}$ DANILEVICZ, Rosane Beatriz Jachimovski. O princípio da essencialidade na tributação. Direito tributário em questão. Revista da FESDT, Porto Alegre, v. 2, n. 3, p. 242, jan./jun. 2009.

${ }^{21}$ PAULSEN, Leandro; MELO, José Eduardo Soares de. Impostos federais, estaduais e municipais. 4. ed. rev. e atual. Porto Alegre: Livraria do Advogado, 2008. p. 264.

${ }^{22}$ BOTTALLO, Eduardo Domingos. IPI: princípios e estrutura. São Paulo: Dialética, 2009. p. 54-55. 
mínimos para uma existência saudável, contribuindo, assim, para a efetividade do princípio da dignidade humana.

Na tributação ambiental, busca-se claramente a defesa de um meio ambiente saudável à sociedade, ou seja, de uma vida com qualidade. Dessa forma, a seletividade realizaria a concretização dos referidos objetivos de maneira inigualável, porque oneraria aqueles contribuintes poluidores e, de maneira proporcional, beneficiaria os preocupados com a saúde ambiental.

\section{A Tributação Ambiental no Direito Comparado}

Anteriormente à análise da tributação ambiental no ordenamento jurídico-tributário brasileiro, buscar-se-á realizar breves considerações acerca de como a matéria é tratada no Direito Comparado.

Considerado um dos países mais preocupados com a defesa do meio ambiente, a Suécia apresenta diversos exemplos de tributação ambiental.

Sinteticamente, cumpre apontar os itens de maior relevo na legislação daquele país. Desde 1991, a Suécia conta com impostos sobre óxidos de carbono, onerando as empresas pelo conteúdo dos gases emitidos pela queima de combustíveis conforme o tipo: petróleo, carvão, gás natural, gás liquefeito e gasolina; e com um imposto sobre o dióxido de enxofre incidente sobre a emissão desse gás, aferido diretamente nas grandes instalações industriais. ${ }^{23}$

${ }^{23}$ GUSMÃO, Omara Oliveira de. Proteção ambiental e tributação: O tributo como coadjuvante na concretização do valor constitucional "meio ambiente". Revista Tributária e de Finanças Públicas, São Paulo, Revista dos Tribunais, n. 66, p. 118, jan./fev. 2006. 
Ainda, de maneira exemplar, a legislação sueca prevê a devolução, total ou parcial, dos valores pagos se as empresas efetuarem a instalação de filtros ou outros mecanismos para a redução ou a eliminação dos gases prejudiciais lançados no ambiente. Por fim, insta mencionar que, naquele ordenamento jurídico, também há a imposição de tributos sobre o consumo de energia e sobre a poluição do meio ambiente causada pelos veículos, bem como alguns produtos passaram a ser tributados conforme as respectivas características poluentes. ${ }^{24}$

Destarte, observa-se a completude do Direito Tributário sueco, que, além de demonstrar a preocupação em taxar ferozmente os poluidores, busca favorecer os contribuintes preocupados com o meio ambiente, seja utilizando produtos ecologicamente corretos, seja utilizando-se de meios para a redução ou a eliminação da emissão de poluentes na natureza.

Em Portugal, conforme aponta Nabais, há três áreas de pesquisas jurídicas acerca do meio ambiente: 1) responsabilidade civil por danos ambientais; 2) subsídios e subvenções do Direito Financeiro; e 3) os impostos ambientais e os benefícios fiscais ambientais do Direito Fiscal. ${ }^{25}$

No presente estudo, analisar-se-á tão somente o terceiro ponto, ou seja, a defesa do meio ambiente pela tributação.

Para o autor, os impostos contribuem muito pouco para a evolução ecológica de Portugal. Nabais considera que os benefícios ofertados aos bons contribuintes são os que realizam de forma mais efetiva a preservação ambiental.

\footnotetext{
${ }^{24}$ Ibidem, p. 118.

${ }^{25}$ NABAIS, José Casalta. Direito Fiscal e Tutela do Ambiente em Portugal. In: TORRES, Heleno Taveira (Org.). Direito Tributário Ambiental. São Paulo: Malheiros, 2005. p. 412-422.
} 
No Direito espanhol, a tributação ambiental possui finalidade fundamentalmente extrafiscal, sendo regida pelo princípio "quien contamina, paga", modalidade específica do princípio da equivalência, que determina que tanto aquele que contaminou quanto aqueles que utilizarem o meio ambiente para lucrar deverão custear a sua utilização. Isto se dá pelo fato de que ninguém poderá lucrar à custa da sociedade. ${ }^{26}$

Ainda, quanto ao tema, cumpre ressaltar as considerações de Domingo Vasco e Pedro Herrera Molina, para quem os tributos somente têm autêntica natureza ambiental quando os desenhos de seus elementos quantitativos constituam um incentivo para a proteção do meio ambiente. ${ }^{27}$

No Direito norte-americano, diversas são as disposições legais tributárias voltadas para a proteção ambiental. Pode-se apontar a existência do adicional "ambiental" do imposto de renda; a dedutibilidade de doações de terrenos e matas com finalidade preservacionista; o imposto pago pelos refinadores sobre petróleo e derivados e, ainda, o imposto devido pelas empresas químicas sobre produtos químicos perigosos e derivados. ${ }^{28}$

Outra medida adotada é a imposição de sobretaxa no preço dos produtos potencialmente poluentes, tais como vasilhames de bebidas, pneus e baterias de automóveis. ${ }^{29}$

26 TABOADA, Carlos Paolo. El principio "quien contamina paga" y el principio de capacidad econômica. In: TORRES, Heleno Taveira (Org.). Direito Tributário Ambiental. São Paulo: Malheiros, 2005. p. 79-82.

${ }^{27}$ CARBAJO VASCO, Domingo; HERRERA MOLINA, Pedro M. Marco conceptual, constitucional y comunitario de la fiscalidad ecologica. Revista de Direito Tributário, São Paulo: Malheiros, v. 89, p. 121-123, 2003.

${ }^{28}$ COSTA, Regina Helena. Tributação ambiental. In: FREITAS, Vladimir Passos de (Coord.). Direito ambiental em evolução. Curitiba: Juruá, 1998. v. 1. p. 298-301.

${ }^{29}$ ABREU, Rafaela Franco. Op. cit., p. 246-247. 
Na Alemanha, há a adoção, por meio de impostos, de incentivos à produção de veículos com menor cilindrada, catalisadores e gasolina sem plomo (chumbo). ${ }^{30}$ Ainda, há imposto municipal sobre embalagens, pratos e talheres descartáveis e tributação maior sobre veículos não guarnecidos de catalisadores. ${ }^{31}$

Destarte, nota-se que o mundo busca, incessantemente, meios para que o progresso venha acompanhado de preocupações básicas para a manutenção de uma vida saudável à humanidade. Um desses meios foi onerar aquelas entidades que contribuem para o desgaste do meio ambiente, favorecendo, por outro lado, as que assiduamente desenvolvem formas ecologicamente corretas de realizar suas atividades.

Por conseguinte, percebe-se flagrante a finalidade extrafiscal da tributação no Direito Comparado, a qual é aplicada por meio da seletividade "ecológica" de produtos, mercadorias e serviços prestados. ${ }^{32}$

\section{A Tributação Ambiental no Brasil}

Em virtude da intensa degradação ambiental, não foi outra a consequência senão a criação de novo ramo do Direito Tributário, denominado Direito Tributário Ambiental.

\footnotetext{
${ }^{30}$ GUSMÃO, Omara Oliveira de. Op. cit., p. 119.

${ }^{31}$ COSTA, Regina Helena. Op. cit., p. 300.

${ }^{32}$ Cumpre apontar que a palavra "ecológica", no presente trabalho, será utilizada tanto em relação à sustentabilidade ambiental quanto referente à baliza necessária à aplicação do princípio da seletividade.
} 
O professor Heleno Torres, em obra acerca do tema, muito bem definiu esta nova área de pesquisa, considerando-a como:

Ramo da ciência do direito tributário que tem por objetivo o estudo das normas jurídicas tributárias elaboradas em concurso com o exercício de competências ambientais, para determinar o uso de tributo na função instrumental de garantia ou preservação de bens ambientais. ${ }^{33}$

Pode-se concluir que a nova linha de pensamento e preocupações do Direito Tributário se coaduna perfeitamente com a tese defendida por Alfredo Augusto Becker, que prega a necessidade de um Direito Tributário dinâmico e inovador que se comprometa, cada vez mais, com os anseios da humanidade. ${ }^{34}$

A tributação ambiental pode ser singelamente conceituada como o emprego de instrumentos tributários para orientar o comportamento dos contribuintes, bem como para gerar os recursos necessários à prestação de serviços públicos de natureza ambiental. ${ }^{35}$

Isto posto, levando em conta que a proteção do meio ambiente e a promoção da qualidade de vida da sociedade são elementos fundamentais do princípio da dignidade da pessoa humana, reconhecidos constitucionalmente no ordenamento jurídico brasileiro, surgiu a possibilidade de utilizar o sistema tributário nacional como mecanismo para sua concretização. ${ }^{36}$

33 TORRES, Heleno Taveira (Org.). Direito Tributário Ambiental. São Paulo: Malheiros, 2005. p. 101-102.

${ }^{34}$ BECKER, Alfredo Augusto. Teoria Geral do Direito Tributário. 2. ed. São Paulo: Saraiva, 1972. p. 553.

35 COSTA, Regina Helena. Op. cit., p. 297.

${ }^{36}$ ARAÚJO, Luiz Ernani Bonesso de; BARICHELLO, Stefania Eugenia; TEIXEIRA, Michele Oliveira. Tributação ambiental: considerações sobre o ICMS ecológico e alguns tributos verdes de países desenvolvidos. Revista da Procuradoria-Geral do Estado, Porto Alegre, v. 31, n. 66, p. 136, jul./dez. 2007. 
Desta forma, passou-se a pensar e estudar de que maneira os tributos poderiam contribuir para a realização dos direitos das pessoas a um meio ambiente ecologicamente equilibrado.

Observa-se que, até a presente data, não há no Direito brasileiro legislação específica acerca da matéria; no entanto, alguns movimentos vêm surgindo com esta finalidade.

Nesta seara, busca-se, por meio do presente trabalho, contribuir para o desenvolvimento da matéria. Para tanto, serão abordados aqueles impostos em que, teoricamente, há repasse do ônus financeiro ao consumidor final, haja vista a não cumulatividade que lhes é inerente (IPI e ICMS). ${ }^{37}$

Portanto, passar-se-á à análise ecológica dos referidos tributos.

\subsection{IPI}

Conforme muito bem exposto por Roque Carrazza e Eduardo Bottallo, o Imposto sobre Produtos Industrializados (IPI) é tributo que deve ser utilizado como instrumento de ordenação político-econômica. ${ }^{38} \mathrm{O}$ referido tributo possui como escopo estimular as práticas tidas como necessárias e convenientes à sociedade e, em contrapartida, onerar as que não atendam ao interesse social..$^{39}$

\footnotetext{
${ }^{37}$ Difini alerta para a precariedade da distinção dos tributos em diretos e indiretos, considerando que a repercussão econômica pode ocorrer independente do tributo. Para o autor, até mesmo o IRPJ poderia ser repassado ao consumidor, bastando uma elevação do preço do produto até o ponto de cobrir os valores devidos pela tributação. DIFINI, Luiz Felipe Silveira. Op. cit., p. 29-30.

${ }^{38}$ CARRAZZA, Roque Antonio; BOTTALLO, Eduardo Domingos. Op. cit., p. 107.

${ }^{39}$ CARRAZZA, Roque Antonio. Curso de Direito Constitucional Tributário. 24. ed. São Paulo: Malheiros, 2006. p. 97.
} 
Esta característica do IPI, eminentemente extrafiscal, restou materializada com a positivação, na Constituição Federal, do princípio da seletividade, presente no artigo 153, $\S 3$, I, que determina que a alíquota do IPI será seletiva em razão da essencialidade do produto. ${ }^{40}$

Observa-se, assim, que o legislador constituinte determinou que o tributo - que ora se estuda - deverá, obrigatoriamente, observar a essencialidade do bem para fins de tributação. Ainda, conforme já exposto, a essencialidade é aquela que atende aos interesses sociais, regulando o princípio do mínimo existencial.

Esta imposição constitucional significa que o legislador, ao estabelecer as alíquotas e a forma de tributação do IPI, não poderá incluir em seu rol os produtos industrializados que sejam artigos de primeira necessidade à população. Portanto, aqueles produtos considerados populares e convenientes ao povo não deverão ser tributados pelo referido imposto. ${ }^{41}$

Assim, observando-se a necessidade popular de um meio ambiente ecologicamente equilibrado, bem como a obrigatoriedade de observação, por parte do IPI, à essencialidade dos bens tributados, conclui-se que aqueles produtos que contribuírem para a manutenção de um meio ambiente saudável devem ser observados e valorizados pelo legislador.

Que há a aplicação do princípio da seletividade ao IPI, isto é notório, basta verificar que, para produtos básicos,

${ }^{40}$ O referido dispositivo assim leciona: "I - será seletivo, em função da essencialidade do produto;"

${ }^{41}$ NOGUEIRA, Ruy Barbosa. Princípio da seletividade do tributo em função da essencialidade do produto. São Paulo: Revista dos Tribunais, 1990. v. 651. p. 10. 
tais como alimentos, a alíquota é relevantemente baixa, ou até zerada, enquanto nos casos de produtos considerados supérfluos, como bebidas e cigarros, as alíquotas são fortemente elevadas (sobre a vodca incide uma alíquota de $60 \%$, enquanto sobre os cigarros ela é de $300 \%){ }^{42}$

No entanto, o que se busca não é o emprego da necessidade como parâmetro único da tributação do IPI, mas também utilizar a sustentabilidade como baliza para a definição de alíquotas e bases de cálculo.

Bom exemplo quanto ao tema é o Decreto Federal

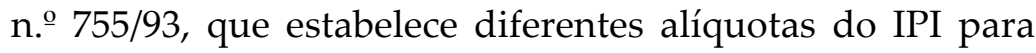
veículos movidos a gasolina (25 ou 30\%) e para veículos movidos a álcool (20 ou 25\%). ${ }^{43}$ No entanto, imprescindível é apontar que a finalidade do referido diploma legal, à época, não era a preservação ambiental, mas sim o incentivo à produção de veículos movidos a álcool, diminuindo, assim, a importação de petróleo. ${ }^{44}$

Entretanto, muito embora não tenha havido o pensamento em prol do ambiente, a criação do decreto pode ser considerada um grande passo para a preservação da natureza.

Exemplo prático acerca dos problemas existentes na tributação do IPI pode ser dado quando se fala do transporte de pessoas. Conforme disposto no item 8703.21.00 da Tabela de Incidência do IPI (TIPI), os veículos automotores de transporte de até seis passageiros, de cilindrada não superior a

\footnotetext{
42 Vide Tabela de Incidência do IPI. Anexo Único do Decreto n. ${ }^{\circ}$ 7.660, de 23 de dezembro de 2011.

${ }^{43}$ BRASIL. Decreto Federal n. 55/93, de 19 de fevereiro de 1993. Reduz as alíquotas do Imposto sobre Produtos Industrializados incidente sobre os veículos automotores que enumera. Diário Oficial da União, Brasília, p. 2272, 20 fev. 1993.

${ }^{44}$ COSTA, Regina Helena. Op. cit., p. 301-302.
} 
$1.000 \mathrm{~cm}^{3}$, são tributados com alíquota de 7\%. Já sobre os veículos em iguais condições, mas com cilindrada entre 1.000 e $1.500 \mathrm{~cm}^{3}$, a alíquota do IPI chega a 13\%. Aparentemente, pode-se pensar que o tributo está cumprindo sua função ambiental, uma vez que onera o veículo mais poluente. No entanto, o mesmo pensamento não prevalece quando analisado o item 8712.00 .10 da referida tabela, que tributa as bicicletas com alíquota de $10 \%$.

Consequentemente, observa-se, no caso em tela, que há clara preferência do legislador por tributar brandamente os veículos, desfavorecendo as bicicletas. No entanto, cumpre lembrar que estas são meios de transporte totalmente limpos, ou seja, não agridem, de maneira alguma, o meio ambiente. Já os primeiros são constantes emissores de gases tóxicos e poluentes no ar.

Destarte, tem-se como necessária a adoção de critérios ambientais para valoração da seletividade, tributando com maior voracidade aqueles produtos poluidores e brandamente aqueles ecologicamente corretos. Nestes termos, em observância aos princípios do mínimo existencial e da seletividade, pode-se afirmar que estes últimos possuem amplo respaldo para ser contemplados com alíquotas diferencialmente reduzidas, ou, se possível, zeradas.

\subsection{ICMS}

Ao estudar as normas do Imposto sobre Circulação de Mercadorias e Serviços (ICMS), que também incide sobre as prestações de serviços de transporte interestadual, intermunicipal e de comunicação, observa-se a existência do 
princípio da seletividade, entretanto de maneira diversa daquela estudada no imposto sobre produtos industrializados.

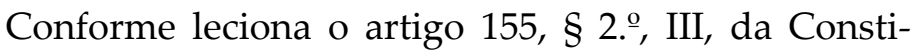
tuição Federal, o ICMS poderá ser seletivo, em função da essencialidade das mercadorias e dos serviços. ${ }^{45}$ Dessa forma, ao disciplinar a utilização do tributo supracitado, o legislador apontou que ele poderá ser seletivo, e não deverá ser, como ocorre no caso do IPI.

Desse modo, pela literalidade do dispositivo legal, chega-se à conclusão de que, no caso do ICMS, não há a obrigatoriedade de o ente tributante observar a essencialidade do bem para fixar suas alíquotas, mas deverá fazê-lo.

Nesses termos, cumpre apresentar o ensinamento de Leandro Paulsen e José Eduardo Soares de Melo, que alertam para a utilização arbitrária da facultatividade da observância da seletividade nos casos do ICMS. ${ }^{46}$ Para os autores, muito embora seja opcional a aplicação do princípio a esses casos, não se justificariam consideráveis elevações de alíquota nos casos de produtos de primeira necessidade, com a simplória justificativa de necessidade de arrecadação.

Observa-se que a facultatividade apresentada oportunizou uma maior flexibilidade ao legislador, mas não lhe transferiu o poder absoluto de fixar as alíquotas do ICMS sem observar princípios e necessidades constitucionalmente defendidos.

Tamanha é a discussão acerca do tema e a preocupação com a garantia das necessidades básicas da sociedade que

\footnotetext{
${ }^{45}$ O referido dispositivo assim leciona: "III - poderá ser seletivo, em função da essencialidade das mercadorias e dos serviços; [...]".

${ }^{46}$ PAULSEN, Leandro; MELO, José Eduardo Soares de. Op. cit., p. 264.
} 
Carrazza considerou que tanto o IPI quanto o ICMS devem ser utilizados como instrumentos de extrafiscalidade e estimular os contribuintes à utilização de meios mais benéficos à sociedade, quando do exercício de suas atividades. ${ }^{47}$

Destarte, cumpre apontar que, muito embora o dispositivo legal apresente como facultativa a aplicação do princípio da seletividade nos casos de tributação pelo ICMS, considera-se que ela deverá ocorrer em prol das garantias do mínimo existencial e da dignidade da pessoa humana.

Avançando no tema em questão, pode-se apontar que as alíquotas para a tributação pelo ICMS se dividem em dois grandes grupos: $1 .^{\circ}$ ) operações interestaduais; e $2 . .^{\circ}$ ) operações internas.

No primeiro caso, conforme a Resolução do Senado n. ${ }^{-}$ 9422 , de 1989, as alíquotas são de 12\% nas operações destinadas a contribuintes localizados nos Estados de Minas Gerais, Rio de Janeiro, São Paulo, Santa Catarina e Rio Grande do Sul, e de $7 \%$ quando destinadas a contribuintes situados nos demais Estados da Federação. ${ }^{48}$

No segundo caso - operações internas -, as alíquotas são assim determinadas: a) 17\% é a alíquota básica, a qual se aplica às operações que não possuem alíquota específica; b) $12 \%$ é a alíquota reduzida, a qual se aplica às mercadorias consideradas mais essenciais, como os produtos integrantes da cesta básica de alimentos, tijolos, fornecimento de refeições

${ }^{47}$ CARRAZZA, Roque Antonio. Op. cit., 2006b, p. 95-97.

${ }^{48}$ BRASIL. Resolução do Senado Federal noำ22, de 19 de maio de 1989. Estabelece alíquota do imposto sobre operações relativas a circulação de mercadorias e sobre prestação de serviços de transporte interestadual e intermunicipal e de comunicação, nas operações e prestações interestaduais. Diário Oficial da União, Brasília, p. 7221, 22, maio 1989. 
etc.; e c) $25 \%$ é a alíquota majorada, aplicada a produtos supérfluos, tais como cigarros, bebidas, armas, perfumaria e cosméticos, bem como aos serviços de telecomunicações e energia elétrica. ${ }^{49}$

Dessa forma, salvo variações específicas, as alíquotas do ICMS sobre operações interestaduais são de sete ou $12 \%$ e, nas operações internas, de 12 , 17 ou $25 \%$.

Entretanto, da mesma forma como ocorre no IPI, porém de maneira mais precária, as alíquotas do ICMS somente obedecem ao princípio da seletividade nos casos de necessidade vital da sociedade. Em nenhum momento há a variação de alíquotas em conformidade com os danos ambientais que a mercadoria ou o serviço transportado podem causar ao meio ambiente.

Ainda, ressalta-se que, nas operações interestaduais, nem a seletividade é atendida, uma vez que são fixadas duas alíquotas, variando tão somente em função do ente federado destinatário.

Portanto, observa-se que o ICMS não possui nenhum método de variação de alíquota em função dos critérios de sustentabilidade. A pouca utilização da seletividade nesse tributo somente se manifesta quando se fala em alíquotas internas, e, mesmo assim, as mercadorias e os serviços somente são classificados em face dos critérios de alimentação, vestuário, transportes etc., ou seja, fundamentos básicos e frágeis para determinar as reais necessidades humanas.

Cristalino é que os referidos critérios são essenciais à sobrevivência, entretanto outros tantos critérios devem ser

${ }^{49}$ PAULSEN, Leandro; MELO, José Eduardo Soares de. Op. cit., p. 254-255. 
observados, como é o caso da sustentabilidade das mercadorias e dos serviços utilizados, o que, atualmente, não ocorre no ordenamento jurídico brasileiro.

\subsection{ICMS Ecológico}

Muito embora não se trate de espécie tributária, o ICMS ecológico é uma prática amplamente adotada entre os Estados e deve ser, ao menos, referida no presente trabalho, com o escopo de ressaltar a preocupação ambiental presente entre os entes federados.

Conforme determina o artigo 158, IV, da Constituição Federal, 25\% do produto da arrecadação do ICMS deverá ser creditado aos municípios. ${ }^{50}$ Desse percentual, conforme determinam os incisos do parágrafo único do mesmo dispositivo legal, três quartos deverão ser creditados segundo o critério de valor adicionado e um quarto, segundo dispuser lei estadual..$^{51}$

Valendo-se deste menor percentual que a legislação conferiu, os Estados vêm criando uma nova política perante os municípios, balizando o repasse financeiro do referido montante através de parâmetros notadamente ambientais.

${ }^{50}$ O referido dispositivo assim determina: "IV - vinte e cinco por cento do produto da arrecadação do imposto do Estado sobre operações relativas à circulação de mercadorias e sobre prestações de serviços de transporte interestadual e intermunicipal e de comunicação".

${ }^{51}$ Os referidos dispositivos assim lecionam: "Parágrafo único. As parcelas de receita pertencentes aos Municípios, mencionadas no inciso IV, serão creditadas conforme os seguintes critérios: I - três quartos, no mínimo, na proporção do valor adicionado nas operações relativas à circulação de mercadorias e nas prestações de serviços, realizadas em seus territórios; II - até um quarto, de acordo com o que dispuser lei estadual ou, no caso dos Territórios, lei federal". 
Os valores e os critérios, legalmente estabelecidos, passaram então a ser quantificados diante de dados fáticos, gerando, com isso, um ranking ecológico dos municípios. Através do referido instrumento, o Estado arrecadador pode verificar o comprometimento dos entes municipais com o meio ambiente, e, quanto maior for seu compromisso ambiental, maior será a verba por esses percebida. Portanto, trata-se da adoção de critérios ambientalmente relevantes para a repartição das receitas normalmente obtidas.

Assim, observa-se que o referido instituto visa a estimular os municípios a preservar o meio ambiente, seja confrontando os poluidores, seja reservando espaços para a preservação ambiental. Nota-se que os critérios de avaliação para a distribuição da renda devem ser estabelecidos em lei estadual, em face do disposto no artigo 158, parágrafo único, II, da Constituição Federal.

Por conseguinte, o referido instituto corrobora plenamente o objetivo do estudo em tela, uma vez que visa a um tratamento diferenciado àqueles municípios preocupados com a saúde ambiental.

Observa-se que esta iniciativa já é aplicada em grande parte do país, incluindo os Estados do Paraná (pioneiro a adotar o ICMS ecológico), Acre, Amapá, Ceará, Mato Grosso, Mato Grosso do Sul, Minas Gerais, Pernambuco, Piauí, Rio de Janeiro, Rio Grande do Sul, Rondônia, São Paulo e Tocantins. ${ }^{52}$

${ }^{52}$ ABREU, Rafaela Franco. Op. cit., p. 243. 


\section{Proposta Valorativa da Tributação Ambiental}

Conforme amplamente abordado no transcorrer do presente trabalho, necessário é que os produtos ecologicamente corretos recebam tratamento diferenciado, em face da função relevantemente social que possuem.

Insta apontar que, além do direito fundamental de o ser humano não ser privado de sua vida e dispor de todos os meios apropriados de subsistência e de padrão de vida decente, o direito à vida engloba, também, a garantia de um meio ambiente equilibrado, que, inclusive, é observada e assegurada pela Constituição Federal em seus artigos 170, VI, e $225 .{ }^{53}$ Logo, não se trata de uma busca inerente aos interesses sociais, mas de uma total afinidade com eles.

Nesta seara, busca-se uma maneira de, através do Direito Tributário, realizar o direito a um meio ambiente ecologicamente equilibrado, o que se faz através de uma tributação "ecológica".

Ricardo Carneiro muito bem aponta que os tributos ambientais podem realizar os objetivos da tutela protetiva do meio ambiente de três maneiras distintas: $1 .^{\circ}$ ) podem ser utilizados como incentivos aos produtores e aos consumidores finais, resultando na readequação de seus processos, comportamentos e hábitos com vistas a uma utilização mais eficiente e equilibrada dos insumos naturais e dos produtos oriundos; 2. $\left.{ }^{\circ}\right)$ os tributos ambientais também podem originar as receitas necessárias aos cofres públicos, as quais poderiam fomentar os projetos de melhoria da qualidade ambiental, permitindo, ainda, a desoneração progressiva dos encargos incidentes

${ }_{53}$ VIEIRA, Andréia Costa. Op. cit., p. 18-19. 
sobre o trabalho e sobre o capital; e $3 .^{\circ}$ ) os tributos podem construir mecanismos eficientes para o controle de proliferação de fontes não estacionárias ou difusas de poluição. ${ }^{54}$

Assim, consoante análise realizada por Carneiro, pode-se concluir que a tributação ambiental, mais do que mera forma de arrecadação do Estado, é eficiente meio para a realização de diversos fins sociais, entre eles, a busca por um meio ambiente sustentável.

Neste sentido, considera-se que a utilização do critério ambiental, como baliza do princípio da seletividade, traria ao Direito brasileiro enorme ganho, pois, de um lado, aumentaria a arrecadação de tributos, diante da tributação agressiva aos produtos, mercadorias e serviços poluentes, e, de outro lado, auxiliaria de forma imprescindível a busca por um meio ambiente saudável.

Desta forma, pretende-se que a valoração do princípio da seletividade observe critérios ecológicos a serem desenvolvidos pela união das forças ambientais e jurídicas, adequando, assim, a tributação aos valores buscados pela sociedade.

Cumpre reiterar que, seja na criação de novas incidências tributárias, seja na diferença de graduação imposta à carga tributária, privilegiando atividades "limpas" ou onerando aquelas poluentes, o que está em causa não é apenas - ou propriamente - a arrecadação fiscal, mas a "finalidade" de promover a "defesa do meio ambiente". ${ }^{55}$

${ }^{54}$ CARNEIRO, Ricardo. Direito Ambiental: uma abordagem econômica. Rio de Janeiro: Forense, 2003. p. 80.

55 OLIVEIRA, José Marcos Domingues. Direito Tributário e Meio Ambiente: proporcionalidade, tipicidade aberta, afetação da receita. Rio de Janeiro: Forense, 1995. p. 39. 
Portanto, plenamente plausível é a observação do princípio da seletividade pelos valores ambientais, fortalecendo, com isso, a defesa ao meio ambiente e proporcionando à humanidade uma vida relevantemente mais salutar.

Destarte, analisa-se que, mesclando as funções fiscais e extrafiscais da tributação ambiental, a lei tributária possuiria plenas condições para fazer a distinção entre poluidores e não poluidores. Assim, premiaria os contribuintes que colaborassem para a preservação ambiental, orientando-os quanto à promoção do equilíbrio ecológico. ${ }^{56}$

\section{Considerações Finais}

Embora tenha-se chegado ao final da presente exposição, muito ainda há de se falar acerca da matéria proposta. Aponta-se que o presente trabalho não objetivou o esgotamento do tema posto em debate, mas sim uma reflexão sobre o assunto, buscando apresentar as possíveis soluções para a concretização, pelas vias do Direito Tributário, da prerrogativa constitucional a um meio ambiente ecologicamente equilibrado.

Para tanto, no primeiro capítulo, buscou-se realizar uma breve análise histórica dos movimentos globais em prol da defesa do meio ambiente, bem como de sua evolução. Ainda, demonstrou-se a presença da referida preocupação no ordenamento jurídico brasileiro, disposta nos artigos 170, VI, e 225 da Constituição Federal.

Posteriormente, passou-se à análise do Direito Comparado, buscando apresentar como a matéria se comporta no

${ }^{56}$ Ibidem, p. 28. 
exterior. Além disso, fez-se análise conceitual da extrafiscalidade tributária e do princípio da seletividade, demonstrando a possibilidade de eles contribuírem para a concretização dos direitos supramencionados.

Depois, examinou-se a tributação ambiental no Direito brasileiro, buscando conceituá-la e verificar os meios possíveis para sua concretização. Constatou-se que, até o presente momento, inexiste legislação específica prevendo a sua utilização; no entanto, algumas práticas tributárias já são amplamente empregadas para a sua efetivação. Assim sendo, passou-se à investigação da presença da tributação ambiental no IPI e no ICMS.

Quanto ao IPI, observou-se que a seletividade se impõe plenamente, uma vez que a Constituição Federal, em seu artigo 153, § 3. , I, assim determina. No entanto, nesses casos, a seletividade tem sido aplicada com observância exclusiva dos direitos à liberdade e de o ser humano possuir meios apropriados de subsistência e de padrão de vida decente. Nesta seara, não é tratado o direito ambiental como limitador da tributação seletiva do IPI, passando, portanto, distante deste tributo, o que não se demonstra cabível.

No que diz respeito ao ICMS, a situação é ainda mais grave, porque nesse tributo nem ao menos o princípio da seletividade é respeitado, sob a justificativa da "facultatividade" de sua aplicação, disposta no artigo 155, § 2. . , III, da Constituição Federal. Poucas são as variações de alíquotas no ICMS, principalmente nos casos de operações internas, mas em nenhum dos casos é observado o meio ambiente como valor necessário à obtenção de uma vida digna.

Dessa forma, buscou-se relacionar o princípio da seletividade e a tutela por um meio ambiente saudável, objetivando 
sua aplicação efetiva através do IPI e do ICMS, o que conclui-se - é plenamente possível. Aponta-se que o direito buscado é item necessário a uma boa qualidade de vida e também valor almejado por toda a sociedade.

Ressalta-se, ademais, que o direito a um meio ambiente sadio e ecologicamente equilibrado é verdadeiro prolongamento do direito de viver. E preservar o meio ambiente, em últimas palavras, quer dizer preservar a vida em todas as suas formas. ${ }^{57}$

Portanto, propõe-se uma valoração ecológica da seletividade tributária, utilizando como baliza a contribuição do produto, da mercadoria e do serviço para a obtenção de um meio ambiente ecologicamente correto. Assim, concretizar-se-iam os princípios da dignidade humana e do mínimo existencial, ofertando aos cidadãos melhor qualidade de vida, fator necessário a uma existência honrada.

\section{Referências}

ABREU, Rafaela Franco. A tributação ambiental no Brasil e nos Estados Unidos - Uma análise comparativa. Publicações da Escola da AGU, Brasília, v. 4, n. 16, p. 233-252, mar. 2012.

AMARAL, Paulo Henrique. Direito Tributário Ambiental. São Paulo: Revista dos Tribunais, 2007. 240 p.

ARAÚJO, Luiz Ernani Bonesso de; BARICHELLO, Stefania Eugenia; TEIXEIRA, Michele Oliveira. Tributação ambiental: considerações sobre o ICMS ecológico e alguns tributos verdes de países desenvolvidos. Revista da Procuradoria-Geral do Estado, Porto Alegre, v. 31, n. 66, p. 135-151, jul./dez. 2007.

BALEEIRO, Aliomar. Direito Tributário brasileiro. 7 ed. Rio de Janeiro: Forense, 1975. 607 p.

${ }^{57}$ RODRIGUEIRO, Daniela A; SOUZA, Luiz Gustavo Alves de. Op. cit., p. 345. 
BECKER, Alfredo Augusto. Teoria Geral do Direito Tributário. 2 ed. São Paulo: Saraiva, 1972. 621 p.

BOTTALLO, Eduardo Domingos. IPI: princípios e estrutura. São Paulo: Dialética, 2009. 208 p.

BRASIL. Código Tributário Nacional. Disponível em: <http://www. planalto.gov.br/ ccivil_03/leis/15172.htm>. Acesso em: 2 jun. 2013.

. Constituição da República Federativa do Brasil de 1988. Disponível em: <http://www.planalto.gov.br/ccivil_03/constituicao/constituicao.htm>. Acesso em: 1 jun. 2013.

. Decreto Federal n. $.755 / 93$, de 19 de fevereiro de 1993. Reduz as alíquotas do Imposto sobre Produtos Industrializados incidente sobre os veículos automotores que enumera. Diário Oficial da União, Brasília, p. 2272, 20 fev. 1993.

. Resolução do Senado Federal nº 22, de 19 de maio de 1989. Estabelece alíquota do imposto sobre operações relativas a circulação de mercadorias e sobre prestação de serviços de transporte interestadual e intermunicipal e de comunicação, nas operações e prestações interestaduais. Diário Oficial da União, Brasília, p. 7221, 22 maio 1989.

CALIENDO, Paulo. Tributação e mercado de carbono. In: TORRES, Heleno Taveira (Org.). Direito Tributário Ambiental. São Paulo: Malheiros, 2005. p. 872-894.

CARBAJO VASCO, Domingo; HERRERA MOLINA, Pedro M. Marco conceptual, constitucional y comunitario de la fiscalidad ecologica. Revista de Direito Tributário, São Paulo: Malheiros, v.89, p. 117-166, 2003.

CARNEIRO, Ricardo. Direito Ambiental: uma abordagem econômica. Rio de Janeiro: Forense, 2003. 176 p.

CARRAZZA, Roque Antonio. Curso de Direito Constitucional Tributário. 22. ed. São Paulo: Malheiros, 2006a. 1041 p.

. Curso de Direito Constitucional Tributário. 24. ed. São Paulo: Malheiros, 2006b. 1080 p.

; BOTTALLO, Eduardo Domingos. IPI, seletividade e alteração de alíquotas. Revista Dialética de Direito Tributário, São Paulo, n. 159, p. 107-114, dez. 2008. 
COSTA, Regina Helena. Tributação ambiental. In: FREITAS, Vladimir Passos de (Coord.). Direito ambiental em evolução. Curitiba: Juruá, 1998. v. 1. p. 297-309.

DANILEVICZ, Rosane Beatriz Jachimovski. O princípio da essencialidade na tributação. Direito tributário em questão. Revista da FESDT, Porto Alegre, v. 2, n. 3, p. 229-245, jan./jun. 2009.

DIFINI, Luiz Felipe Silveira. Manual de Direito Tributário. 4. ed. atual. São Paulo: Saraiva, 2008. 378 p.

GUSMÃO, Omara Oliveira de. Proteção ambiental e tributação: O tributo como coadjuvante na concretização do valor constitucional "meio ambiente". Revista Tributária e de Finanças Públicas, São Paulo, Revista dos Tribunais, n. 66, p. 113-148, jan./fev. 2006.

NABAIS, José Casalta. Direito Fiscal e Tutela do Ambiente em Portugal. In: TORRES, Heleno Taveira (Org.). Direito Tributário Ambiental. São Paulo: Malheiros, 2005. p. 412-444.

NOGUEIRA, Ruy Barbosa. Princípio da seletividade do tributo em função da essencialidade do produto. São Paulo: Revista dos Tribunais, 1990. v. 651.

OLIVEIRA, José Marcos Domingues. Direito Tributário e Meio Ambiente: proporcionalidade, tipicidade aberta, afetação da receita. Rio de Janeiro: Forense, 1995. 280 p.

PAULSEN, Leandro; MELO, José Eduardo Soares de. Impostos federais, estaduais e municipais. 4 . ed. rev. e atual. Porto Alegre: Livraria do Advogado, 2008. 420 p.

RODRIGUEIRO, Daniela A; SOUZA, Luiz Gustavo Alves de. Do caos à consciência ecológica: breves reflexões sobre degradação e preservação ambiental. Revista do Instituto de Pesquisas e Estudos, Bauru, Divisão Jurídica, n. 48, p. 337-350, jul. 2007.

TABOADA, Carlos Paolo. El principio "quien contamina paga" y el principio de capacidad económica. In: TORRES, Heleno Taveira (Org.). Direito Tributário Ambiental. São Paulo: Malheiros, 2005. p. 79-95.

TEIXEIRA, Dalvio Leite Dias; TEIXEIRA, Silvia Maria Benedetti. A constitucionalidade da tributação ambiental no Brasil. Revista da AJURIS, Associação dos Juízes do Rio Grande do Sul, Porto Alegre, v. 36, n. 115, p. 73-84, set. 2009. 
TORRES, Heleno Taveira (Org.). Direito Tributário Ambiental. São Paulo: Malheiros, 2005. 894 p.

VIEIRA, Andréia Costa. O direito humano ao meio ambiente e a tributação ambiental: água e ar: mecanismos nacionais e internacionais. Fórum de Direito Urbano e Ambiental, Belo Horizonte, v. 9, n. 53, p. 18-26, set./out. 2010.

Submissão: 09/06/2013 Aceito para Publicação: 14/08/2013 



\title{
A (In)aplicabilidade do Instituto da Sucessão Trabalhista na Atividade Notarial e Registral
}

\author{
The Non-applicability of the Labor Succession \\ Institute in the Notary and Registry Service
}

Renata Hellwig Ferreira*

Resumo: $\mathrm{O}$ presente trabalho visa a analisar a aplicabilidade do instituto da sucessão trabalhista brasileiro na atividade notarial e registral. Tal questão mostra-se pertinente, uma vez que o mencionado instituto do direito laboral opera-se, em suma, quando há substituição do empregador, com mudança na propriedade da empresa ou alteração na sua estrutura jurídica, ainda que haja ruptura na continuidade da atividade empresarial. Os serviços notariais e registrais, no entanto, possuem regime jurídico próprio, diverso daquele aplicado à empresa, sendo a responsabilidade trabalhista do titular da serventia (tabelião ou registrador), tendo em mente que a serventia não tem personalidade jurídica. Ocorre que, atualmente, o instituto justrabalhista é interpretado extensivamente, abarcando novas situações. Desse modo, ante as peculiaridades desse serviço público delegado, prestado em caráter privado, sendo o delegatário nomeado pelo Poder Público, após aprovação em concurso público, cabe trazer à baila questões como se há ruptura da cadeia sucessória entre a extinção da delegação a um e a nomeação de outro, nesse sentido não se caracterizando a sucessão, ou se há elementos suficientes para caracterizá-la, bem como se o sucessor responde pelos débitos quando não há continuidade da prestação de serviços e, ainda, se a extinção da delegação desincumbe totalmente o sucedido.

\footnotetext{
Universidade Federal de Pelotas.
} 
Palavras-chave: Sucessão Trabalhista. Atividade Notarial e Registral. Substituição. Delegação. Solidariedade.

Abstract: This paper aims to analyze the applicability of the Brazilian labor succession institute in the notary and registry services. Such question is relevant, once that the mentioned institute of Labor Law occurs, in short, when there is a substitution of the employer, with a change in the property of the corporation or a modification in its legal structure, even if there is a rupture in the continuity of the corporative activity. The notary and registry services, however, have a distinct juridical regime, different from the one applied to the corporation, being the labor liability of the one entitled of the public service (the notary or the register), having in mind that the public service has no legal personality. It occurs that, nowadays, the labor institute is interpreted extensively, covering new situations. This way, the peculiarities of this delegated public service - provided in a private nature, being the delegate named by the Public Authorities, after a competitive tendering - can moot questions like if there is a rupture of the succession chain between the extinction of the delegation to one and the naming of another, in this sense not characterizing the succession, or if there are enough elements to characterize it, as well as if the successor is liable for unpaid debts when there is no continuity in the providing of the public service, and, still, if the extinction of the delegation brings no liability for the successor.

Keywords: Labor Succession. Notary and Registry Services. Substitution. Delegation. Solidarity.

\section{Introdução}

A atividade notarial e registral apresenta muitas peculiaridades dentro do ordenamento jurídico brasileiro e vem sendo homogeneizada em todos os Estados-membros, com regulamentação e fiscalização da atividade, o que se verificou 
a partir da promulgação da Constituição Federal de 1988, que disciplinou os serviços, indicando os parâmetros a serem seguidos, tais como a necessidade de concurso público para ingresso na atividade, o que retirou o caráter hereditário outrora existente nos cartórios.

Diante disso, veio a lume a controvérsia no tocante à responsabilidade pelos débitos trabalhistas quando há mudança na titularidade da serventia extrajudicial, tema pouco abordado doutrinariamente, mas divergente na jurisprudência pátria, cuja problemática se procura enfrentar no presente trabalho.

Com o fito de alcançar conclusões acerca do tema, procurou-se trabalhar, primeiramente, a atividade no ordenamento jurídico pátrio, abordando-se seu aspecto de serviço público delegado ao Notário ou Registrador.

Ademais, procurou-se definir o instituto da sucessão trabalhista, ante sua nova caracterização, sendo concebida de maneira mais abrangente e culminando com a análise da aplicabilidade de tal instituto quando há mudança do titular da atividade notarial e registral, abordando-se a necessidade de continuidade da prestação de serviço pelo obreiro, bem como a possibilidade de responsabilidade solidária ou subsidiária entre sucessor e sucedido, não se buscando esgotar o tema, e sim encontrar possibilidades de atrelar o instituto justrabalhista à atividade, dadas as suas especificidades, mantendo-se em consonância com o sistema jurídico. 


\section{A Atividade Notarial e Registral}

A atividade notarial e de registros é concebida no ordenamento jurídico brasileiro como os serviços de organização técnica e administrativa destinados a garantir publicidade, autenticidade, segurança e eficácia aos atos jurídicos, consoante dispõe o art. $1^{\mathrm{o}}$ da Lei $\mathrm{n}^{\mathrm{o}}$ 8.935/1994, norma que regulamentou o art. 236 da Constituição Federal ${ }^{1}$.

O referido dispositivo constitucional enfrentou com abordagem inédita a matéria relativa a esses serviços que, conforme ensina Silva (2010, p. 895), a tradição e o ordenamento jurídico nacional sempre chamaram de serventias do foro extrajudicial (denominação corroborada, inclusive, pelo parágrafo $3^{\mathrm{o}}$ do artigo em comento ${ }^{2}$ ), definindo contornos à atividade.

Esses serviços, comumente designados pelo termo "cartório", compreendem os Tabelionatos de notas, de protestos de títulos e de contratos marítimos, bem como os Ofícios de Registros de Imóveis, de títulos e de documentos e civis das pessoas jurídicas, civis das pessoas naturais e de interdições e tutelas, e ainda, de distribuição ${ }^{3}$, este, quando houver mais de um tabelionato de protestos na comarca.

1 Art. 236. Os serviços notariais e de registro são exercidos em caráter privado, por delegação do Poder Público.

$\S 1^{\circ}$. Lei regulará as atividades, disciplinará a responsabilidade civil e criminal dos notários, dos oficiais de registro e de seus prepostos, e definirá a fiscalização de seus atos pelo Poder Judiciário.

$\S 2$ ‥ Lei federal estabelecerá normas gerais para a fixação de emolumentos relativos aos atos praticados pelos serviços notariais e de registros.

$\S 3^{\circ}$. O ingresso na atividade notarial e de registro depende de concurso público de provas e títulos, não se permitindo que qualquer serventia fique vaga, sem abertura de concurso de provimento ou de remoção, por mais de seis meses.

2 Vide 1.

3 Art. $5^{\circ}$ da Lei 8.935/1994. 


\subsection{Natureza Jurídica: Serviço Público Delegado}

Conforme o art. 236, caput, da Constituição Federal, os serviços notariais e de registro são exercidos em caráter privado, por delegação obrigatória do Poder Público a particular. Desse dispositivo, é possível extrair-se a natureza dos serviços que têm caráter público.

No que tange a serviço público, Celso Antônio Bandeira de Mello (apud SILVA, 2010, p. 896) distingue aqueles prestados pelas serventias extrajudiciais, que afirma serem de ordem jurídica ou formal, tendo característica de ofício ou de função pública, daqueles dispostos no art. 21, XI e XII da $\mathrm{CF}^{4}$, que assevera serem de ordem material, fruíveis diretamente pelos administrados.

O exercício dessa atividade, no entanto, dá-se em caráter privado, realizado por um particular, aprovado em concurso público (pode ser notário ou tabelião ${ }^{5}$, caso assuma espécie de tabelionato, e oficial de registro ou registrador, caso assuma a titularidade de espécie de ofício de registros,

4 Art. 21. Compete à União:

$[\ldots]$

XI - explorar, diretamente ou mediante autorização, concessão ou permissão, os serviços de telecomunicações, nos termos da lei, que disporá sobre a organização dos serviços, a criação de um órgão regulador e outros aspectos institucionais; XII - explorar, diretamente ou mediante autorização, concessão ou permissão:

a) os serviços de radiodifusão sonora, e de sons e imagens;

b) os serviços e instalações de energia elétrica e o aproveitamento energético dos cursos de água, em articulação com os Estados onde se situam os potenciais hidroenergéticos;

c) a navegação aérea, aeroespacial e a infra-estrutura aeroportuária;

d) os serviços de transporte ferroviário e aquaviário entre portos brasileiros e fronteiras nacionais, ou que transponham os limites de Estado ou Território;

e) os serviços de transporte rodoviário interestadual e internacional de passageiros;

f) os portos marítimos, fluviais e lacustres;

5 Kollet (2008, p. 4) afirma que notário é gênero das espécies tabelião de notas, tabelião de protestos e tabelião de contratos marítimos. 
os quais já foram especificados $)^{6}$, e, em razão disso, o titular da serventia organiza-a como se estivesse exercendo uma atividade empresária no que tange aos bens materiais e à contratação de empregados, estando, no entanto, sujeito à fiscalização, punição e coordenação técnica dos serviços pelo Poder Judiciário ${ }^{7}$, o qual realiza função atípica - uma vez que não se trata de atividade inerente à sua natureza jurisdicional (LENZA, 2009, p. 338) - mediante correições, isto é, a verificação da observância dos preceitos legais na consecução dos serviços, que podem ser ordinárias ou extraordinárias. Estas poderão ocorrer a qualquer tempo, inclusive motivadas pela reclamação dos usuários dos serviços; aquelas devem ocorrer anualmente (ARRUDA, 2008, p. 6).

Assim dispõe o art. 20 da lei 8.935/94 ${ }^{8}$. Saliente-se que o contrato de trabalho é celebrado entre o trabalhador e o notário ou registrador, pois a serventia não possui personalidade jurídica, sendo somente organismo montado para o desempenho das atribuições dos notários e registradores.

A delegação do serviço notarial e registral possui regime especial, uma vez que se exige concurso público para o preenchimento das vagas, mas, diversamente do que ocorre com outros serviços públicos, não há contrato administrativo entre Poder delegante e o delegatário da atividade. Regra geral, a delegação é realizada por contrato administrativo, o qual tem como antecedente a licitação - sendo esta o procedimento administrativo mediante o qual a Administração

6 Art. $3^{\circ}$ da Lei 8.935/1994.

7 Art. 236, §1º da CF.

8 Art. 20. Os notários e oficiais de registro poderão, para o desempenho de suas funções, contratar escreventes, dentre eles escolhendo os substitutos e auxiliares como empregados, com remuneração livremente ajustada e sob o regime da legislação do trabalho. 
Pública seleciona a proposta mais vantajosa para o contrato de seu interesse -, salvo nos casos de dispensa, inexigibilidade ou vedação expressamente previstas em lei (MEIRELLES, 2010, p. 281).

Além disso, o ingresso na atividade dá-se mediante provimento originário, não havendo vínculo anterior com o Poder Público, e a investidura na delegação ocorre com a posse perante o Poder Judiciário que, mediante ato administrativo, delega o serviço, sendo que os livros existentes na serventia pertencem ao Estado e ficam sob a responsabilidade do novo titular, que deve organizar a serventia para prestar o serviço de forma eficiente.

Com a extinção da delegação, o antigo titular deixa de organizar e administrar a serventia, extinguindo-se seu vínculo de prestador de serviço público com o Estado, não podendo transferir a titularidade para outrem, conforme sua vontade, ficando o cartório vago, devendo o Poder Judiciário designar substituto para responder interinamente pelos serviços, pois não há assunção imediata de novo titular que, após realização de concurso público e ato administrativo de posse, assumirá o cartório, sem qualquer vínculo com o seu antecessor.

\section{Sucessão Trabalhista}

Ao vocábulo "sucessão" (do latim successio; subcedere, do verbo suceder) são inerentes as ideias de substituição e de continuidade. Substituição, pois necessariamente há uma mudança de titularidade; continuidade, haja vista que essa mudança põe fim a uma relação jurídica, mas inicia outra similar de forma encadeada. No sentido jurídico não é diferente, consoante afirmou De Plácido e Silva (apud SENA, 2000, p. 19): 
[...] na etimologia jurídica, mesmo genericamente, sucessão conduz sentido de substituição, compreendendo-se a vinda de coisa ou de pessoa para colocar-se no lugar ou na posição ocupada por outra, investindo-se na mesma situação jurídica que mantinha a outra coisa ou a outra pessoa.

No direito do trabalho, o instituto sucessório está regulado nos arts. $10^{9}$ e $448^{10}$ da Consolidação das Leis do Trabalho (CLT), dispositivos que possuem o escopo de proteger o empregado de qualquer alteração que ocorra com o empregador e venha a afetar o contrato de trabalho, prejudicando o trabalhador. Essa proteção à parte hipossuficiente da relação empregatícia, qual seja o obreiro, é um dos princípios norteadores do direito trabalhista, quiçá o cardeal desse ramo jurídico especializado, por influir em toda a sua estrutura jurídica, independendo de quem seja o empregador, o que denota sua despersonalização.

O instituto da sucessão trabalhista resta caracterizado em inúmeras situações que Delgado (2012, p. 416) denominou situações-tipo tradicionais e situações-tipo novas, sendo aquele o modelo tradicional no qual se enquadra a maioria das situações fático-jurídicas percebidas no mercado empresarial e este um extensivo que advém de uma nova análise do instituto sucessório a partir de uma nova interpretação dos arts. 10 e 448 da CLT, uma vez que tais normas são genéricas e imprecisas, pelo que a jurisprudência alarga seu sentido, estendendo-o a novas situações. Na teoria tradicional, havia necessidade de continuidade na prestação do serviço pelo empregado (SENA, 2000, p. 15). No modelo novo, por sua

\footnotetext{
9 Art. 10. Qualquer alteração na estrutura jurídica da empresa não afetará os direitos adquiridos por seus empregados.

${ }^{10}$ Art. 448. A mudança na propriedade ou na estrutura jurídica da empresa não afetará os contratos de trabalho dos respectivos empregados.
} 
vez, a sucessão trabalhista pode se verificar sem que haja, necessariamente, a continuidade da prestação de serviços (DELGADO, 2012, p. 417).

As situações tradicionais que caracterizam a sucessão trabalhista são extraídas da interpretação comumente procedida dos próprios dispositivos celetistas, tomando por base certa literalidade da norma. Ambos os dispositivos mencionam alteração na estrutura jurídica da empresa, ou seja, alteração formal na pessoa física ou jurídica que contrata a força de trabalho com vínculo empregatício.

O contexto atual reclama leitura mais abrangente, com uma fundamental releitura dos preceitos sucessórios, pelo que a doutrina entende, em suma, que resta caracterizada a sucessão com a ocorrência de qualquer alteração intra ou interempresarial apta a afetar os contratos de trabalho, assumindo o sucessor as obrigações decorrentes dos contratos empregatícios, ainda que contraídas pelo sucedido.

\subsection{Responsabilidade do Empregador Sucedido}

Com a ocorrência da sucessão trabalhista, o empregador sucessor substitui o anterior, dando continuidade à empresa e mantendo hígidos os contratos de trabalho. No entanto, é mister analisar se o sucedido fica isento de responsabilidade em relação às obrigações trabalhistas que contraiu ou se é cabível a sua responsabilização solidária ou subsidiária.

Primeiramente, impende ressaltar-se que eventual contrato realizado estipulando a responsabilidade do sucedido pelos débitos trabalhistas não produz efeitos em relação aos empregados. Nesse sentido, Arruda (2008, p. 100) diz 
que "pode haver cláusula que preveja a responsabilidade do alienante, mas será ineficaz perante o empregado". Segundo Garcia (2012, p. 307), as normas dos arts. 10 e 448 são de ordem pública, não sendo, portanto, afastadas por estipulação contratual. $\mathrm{O}$ que pode ocorrer, entretanto, é ação regressiva do sucessor em face do sucedido, pleiteando indenização pelos débitos trabalhistas que adimpliu em dissonância com o contratado pelas partes. Ocorre que tal lide dá-se na órbita civil, jamais trabalhista: uma vez caracterizada a sucessão, a responsabilidade pelos débitos resultantes dos contratos de trabalho é do sucessor e, caso reste responsabilização ao sucedido, será a priori solidária ou subsidiária.

Sena (2000, p. 289) afirma que "hoje a preocupação dos aplicadores do Direito não reside apenas em fraudes tendentes à irresponsabilidade (art. 9o da CLT), mas, especialmente, em situações normativas excludentes de responsabilidades". Na sucessão, o sucessor responde pelos débitos trabalhistas não adimplidos pelo sucedido, ainda que o empregado não tenha prestado serviços à sucessora, consoante a nova visão do instituto, havendo responsabilidade solidária em caso de sucessão fraudulenta (GARCIA, 2012, p. 307), em que ambos contribuem para a fraude e, portanto, respondem pelos débitos advindos dos contratos de trabalho.

No entanto, a jurisprudência tem ampliado as possibilidades de responsabilização do sucedido para além dos casos fraudulentos, entendendo que, mesmo não havendo fraude, sendo comprometidas as garantias empresariais deferidas aos contratos de trabalho, incidiria a responsabilidade da empresa sucedida, sendo, entretanto, subsidiária (DELGADO, 2012, p. 428). Extrai-se desse ensinamento que modificações ou transferências empresariais que afetem os contratos de 
trabalho provocam a responsabilização subsidiária da sucedida, em caso de insuficiência de recursos da sucessora.

Entretanto, defendendo a responsabilização subsidiária do sucessor, Fonseca leciona:

A solução já dissemos, a lei nos fornece: não podendo conferir a responsabilidade solidária, que exigiria previsão legal, que a incumbência, na generalidade dos casos, seja da empresa sucedida, a qual beneficiou-se diretamente dos serviços do empregado. Contudo, em proteção a este, na hipótese de não ter a sucedida idoneidade financeira responde o sucessor, subsidiariamente. (FONSECA, Rodrigo Dias apud SENA, 2000, p. 280).

No que tange à responsabilidade solidária do sucessor e do sucedido, Martins (2011, p. 213), em consonância com entendimento majoritário da doutrina, afirma que ela não existe no instituto justrabalhista, por falta de previsão legal, conforme art. 265 do Código Civil ${ }^{11}$, previsão, por sua vez, existente no caso de cisão de empresas, consoante disposto no art. 233 da lei no 6.404/1976 ${ }^{12}$.

Em sentido contrário, leciona Garcia (2012, p. 308) que a solidariedade embasa-se, ainda, com o advento do Código Civil de 2002 que, em seu art. 1.146, dispõe que “o adquirente do estabelecimento responde pelo pagamento dos débitos anteriores à transferência, desde que regularmente

\footnotetext{
11 Art. 265. A solidariedade não se presume; resulta da lei ou da vontade das partes.

12 Art. 233. Na cisão com extinção da companhia cindida, as sociedades que absorverem parcelas do seu patrimônio responderão solidariamente pelas obrigações da companhia extinta. A companhia cindida que subsistir e as que absorverem parcelas do seu patrimônio responderão solidariamente pelas obrigações da primeira anteriores à cisão.

Parágrafo único. O ato de cisão parcial poderá estipular que as sociedades que absorverem parcelas do patrimônio da companhia cindida serão responsáveis apenas pelas obrigações que lhes forem transferidas, sem solidariedade entre si ou com a companhia cindida, mas, nesse caso, qualquer credor anterior poderá se opor à estipulação, em relação ao seu crédito, desde que notifique a sociedade no prazo de noventa dias a contar da data de publicação dos atos da cisão.
} 
contabilizados, continuando o devedor primitivo solidariamente obrigado pelo prazo de um ano, a partir, quanto aos créditos vencidos, da publicação, e, quanto aos outros, da data do vencimento".

No mesmo sentido, Meireles (MEIRELES, Edilton apud SENA, 2000, p. 282) afirma que há previsão legal de responsabilidade solidária, pois, “ao se estabelecer que a mudança da propriedade ou na estrutura jurídica da empresa não afeta os contratos de trabalho dos respectivos empregados (art. 448 da CLT), quer a lei consignar, data venia, apenas que o sucessor deve assumir todas as obrigações decorrentes dos vínculos empregatícios mantidos até então, em proteção aos direitos dos empregados, não significando isso a isenção do sucedido pelos débitos constituídos até então. $\mathrm{O}$ sucedido continuaria responsável pela satisfação de seus débitos, constituídos até a data da sucessão".

Assim, entende-se cabível a responsabilidade solidária na sucessão trabalhista pelos débitos contraídos antes de sua ocorrência, mormente ante a generalidade e imprecisão dos dispositivos celetistas que tratam da matéria, pois não deve um instituto jurídico ser utilizado de forma fraudulenta, o que ocorreria comumente em caso de irresponsabilidade do sucedido.

\section{A (In)aplicabilidade do Instituto da Sucessão Trabalhista na Atividade Notarial e Registral}

Consoante analisado, os artigos 10 e 448 da CLT são interpretados atualmente de maneira extensiva e abrangente, alcançando o instituto justrabalhista as mais variadas situações de alteração na estrutura jurídica da empresa, desde que possam afetar os contratos de trabalho. 
No entanto, os princípios, normas e institutos do direito do trabalho não podem ser isoladamente interpretados e precisam estar em consonância com todo o ordenamento jurídico pátrio, conforme leciona Delgado:

É óbvio que não se pode valer do princípio especial justrabalhista para comprometer o caráter lógico-sistemático da ordem jurídica, elidindo-se o patamar de cientificidade a que se deve submeter todo processo de interpretação de qualquer norma jurídica. (DELGADO, 2012, p. 201).

Isso porque, em que pese a divisão do direito em disciplinas jurídicas, seu estudo deve ser efetivado sob uma visão panorâmica, sendo necessário apreciar essas disciplinas no seu conjunto unitário, pois elas representam e refletem um fenômeno jurídico unitário que precisa ser examinado (REALE, 2002, p. 6).

Ocorre que, partindo-se de uma ideia unificadora de sistema, tentava-se englobar todos os institutos de certa parte do direito numa única descrição, mesmo à custa de distorcer algum aspecto ou instituto jurídico que não se encaixasse nesse sistema (LOSANO, 2007, p. 10). No entanto, as disciplinas e seus institutos possuem características próprias que devem ser observadas quando da sua aplicação a fatos concretos, sob pena de serem criadas verdadeiras aberrações jurídicas que se adequam a novas situações, inobservando suas peculiaridades.

Desse modo, ao verificar a possibilidade de aplicar-se o instituto da sucessão trabalhista quando há mudança na titularidade das serventias notariais e de registro, deve-se fazer uma abordagem singular para uma realidade jurídica igualmente singular, qual seja a dos cartórios extrajudiciais (ARRUDA, 2008, p. 4). 
Assim, Martins (2011, p. 213) leciona que "há sucessão do atual titular do cartório notarial ou registral em relação ao anterior se passa a exercer suas atividades no mesmo imóvel, com os mesmos móveis, arquivos, utilizando as anteriores firmas dos clientes". De fato, tal entendimento coaduna-se sobremaneira com o instituto sucessório e com essa atividade, uma vez que tem o novo notário ou oficial de registro a possibilidade de optar pela transferência do estabelecimento pelo anterior responsável pela serventia, após a assunção da função, estando presente a autonomia da vontade existente nos contratos empresariais em que há sucessão de empresas, o que não ocorre tão somente com a aprovação no concurso e posterior posse, mediante ato administrativo.

Conforme já verificado, segundo a nova interpretação da sucessão trabalhista, não é necessário haver a continuidade do contrato de trabalho para a caracterização do instituto, sendo que o sucessor, ao entabular o negócio jurídico empresarial, deverá estar ciente das responsabilidades trabalhistas. No entanto, em se tratando das serventias extrajudiciais, não parece ser razoável que o novo delegado, recém-aprovado em concurso público, empossado por ato administrativo, em relação direta com o Poder Público, seja responsável pelos débitos trabalhistas do titular anterior do cartório, o qual não adimpliu tais verbas antes da extinção da delegação.

Aplicando-se, analogicamente, entendimento afeto às concessões de serviço público à delegação da atividade notarial e de registro, verifica-se que a Orientação Jurisprudencial no 225 da Seção de Dissídios Individuais 1 (SDI-1) do TST firma disciplina que, havendo contrato de concessão em que uma empresa outorga a outra bens de sua propriedade, a segunda concessionária, na condição de sucessora, responde 
pelos direitos decorrentes do contrato de trabalho, caso este tenha sido rescindido após a concessão, sem prejuízo da responsabilidade subsidiária da concessionária sucedida pelos débitos contraídos até a concessão; além disso, caso não haja continuidade da relação de trabalho após a concessão, a responsabilidade é inteiramente da primeira concessionária.

Nesse caso, somente ficará caracterizada a sucessão trabalhista havendo a continuidade da relação empregatícia com a efetiva prestação de serviços do empregado à nova concessionária, sendo que há também transferência de bens entre as empresas. No caso dos cartórios não há relação direta entre os titulares. Por outro lado, quanto à responsabilidade da sucedida, é possível pensar na solidariedade em caso de inadimplência de verbas trabalhistas quando do término da delegação, o que, inclusive, visa a desestimular o inadimplemento.

Desse modo, não havendo continuidade da relação de trabalho na serventia após a delegação, cumpre a cada titular de cartório responsabilizar-se pelas respectivas contratações. Tal situação possibilita-se, contrariamente ao que ocorre nas relações jurídico-empresariais, na medida em que o empresário que adquire a unidade econômico-jurídica e substitui o antigo proprietário, quando o faz - por contrato privado, presente a autonomia da vontade das partes existente no contrato empresarial -, está ciente de todos os débitos da empregadora. Consabido que no direito do trabalho o elemento volitivo é mitigado, a fim de alcançar-se igualdade jurídica, não se podendo, entretanto, fugir das peculiaridades de cada caso, assim como nos cartórios extrajudiciais, cuja assunção dá-se por ato administrativo, devendo a sucessão ser concebida atentando-se às suas especificidades. 
Assim, sabe-se que essa contratação não ocorre na alteração da titularidade dos cartórios extrajudiciais, pois não há transferência de um direito entre o antigo e o novo titular, e sim aquisição originária de um direito, pois há investidura em concurso público.

Nesse sentido, o Conselho da Magistratura do Tribunal de Justiça do Rio Grande do Sul editou a Resolução número 110/94, determinando que os contratos de trabalho mantidos pelo titular da serventia são considerados extintos com a extinção da delegação, devendo ser quitadas as obrigações trabalhistas e previdenciárias decorrentes dos contratos de trabalho. Tal norma administrativa interna do TJ/RS foi editada visando a evitar que a permanência dos trabalhadores prestando serviços para o cartório fosse entendida como sucessão trabalhista, figurando o Estado como empregador.

Diante desse entendimento, percebe-se que, com a vacância, o Estado retoma a delegação e, somente após a aprovação no concurso público, outro é nomeado para assumir a titularidade da serventia, havendo ruptura no contrato entre vacância e assunção de novo titular. Isso não se coaduna com a ideia do instituto sucessório em que há imediata transferência de direitos e obrigações entre o antigo empregador e seu sucessor.

Assim, sendo a delegação dos serviços notariais e registrais realizada mediante ato administrativo, sem haver transferência imediata de direitos e obrigações entre o antigo e o novo titular da serventia, entende-se cristalino que não havendo continuidade na prestação dos serviços pelo empregado ao novo titular, isto é, efetivo labor, não há que se falar em sucessão trabalhista. 
Esse entendimento consubstancia-se em uma análise sistemática do instituto sucessório, uma vez que, embora haja afetação dos contratos de trabalho, a delegação desses serviços é especial, pois são prestados privativamente, mas entre a extinção da delegação, a nomeação do substituto no período de vacância e a delegação ao novo titular, há intervenção do Poder Público e, com isso, clara ruptura da relação trabalhista, sendo evidente que a despersonalização do empregador, importante base a caracterizar a sucessão do direito do trabalho, inobserva-se no caso.

Garcia (2012, p. 334) advoga que na mudança de titularidade do cartório não se verifica propriamente aquisição, cessão, transação comercial ou civil ou mesmo transferência de titularidade da empresa ou de atividade econômica organizada; há necessariamente a nomeação do aprovado no concurso público pelo Estado, desconhecendo a situação da serventia cuja titularidade assumirá, podendo escolher livremente seus empregados.

Considera-se temerário o entendimento jurisprudencial no sentido de caracterizar o instituto sucessório, em qualquer caso, pois se presume a transferência do complexo de bens quando da mudança da titularidade dos serviços notariais e registrais, equiparando-os com os negócios jurídico-empresariais, a saber, o contrato de trespasse, no qual há transferência do estabelecimento empresarial. Isso porque o novo delegado pode utilizar-se de outra mobília e outro imóvel para o funcionamento da serventia, além de alterar o nome empresarial, recebendo somente o acervo necessário à prestação do serviço público, que são os livros de escrituração. Dessa forma, visto que não é sempre que ocorre a transferência da unidade econômico-jurídica, deve tal situação ser 
observada casuisticamente, sendo argumento determinante para a aplicação da sucessão trabalhista in casu.

Em que pese o novo delegado aprovado no concurso público tenha ciência de que a atividade é exercida em caráter privado e o regime de contratação dos prepostos é o celetista, não há apuração dos débitos anteriormente à posse e à assunção da delegação como ocorre com as relações empresariais, uma vez que, ocorrendo a sucessão empresarial, os débitos anteriores à transferência são contabilizados, o que gera a responsabilidade pelas dívidas decorrentes do exercício da empresa.

Na caracterização e conceituação do instituto sucessório, o vínculo causal entre as partes se forma num momento inicial por vontade dos envolvidos (DELGADO, 2012, p. 293), mas os efeitos muitas vezes decorrem da vontade da lei e não das partes, o que se denota da cláusula de não responsabilização que não produz efeitos em relação aos obreiros, havendo responsabilidade do sucessor, ainda que estipulado o contrário em contrato privado entre esse e o sucedido. Em regra, há aquisição derivada de direitos, através de uma sub-rogação de faculdades, o que não ocorre, todavia, na mudança de titularidade das serventias extrajudiciais, pois com a aprovação no concurso público realizado pelo Poder Judiciário, há aquisição originária de direitos, não existindo em um primeiro momento transferência de direitos, pois o Estado, com a extinção da delegação, retoma a titularidade dos serviços, nomeando substituto e, após, delegando os serviços a novo titular.

Entende-se, assim, que em havendo extinção do contrato de trabalho e havendo uma quebra da cadeia sucessória 
em decorrência do concurso público, não há que se falar em sucessão trabalhista e responsabilidade pelos débitos contraídos anteriormente a sua assunção da função, o que se estende aos empregados que não prestarem efetivo serviço ao novo titular.

Contrariamente, caso haja continuidade da prestação de serviços pelo trabalhador ao atual notário ou registrador, uma vez que continuam o objeto e as finalidades dos serviços, e ao optar pela continuidade da prestação laboral pelos prepostos, o sucessor assume os ônus dos contratos empregatícios, aceitando-se a aplicação do instituto da sucessão trabalhista, sem que haja ofensa ao ordenamento jurídico, protegendo-se os interesses dos obreiros, qual seja o objetivo principal do direito trabalhista.

Igualmente, caso a dispensa do empregado pelo novo titular da serventia assim que assumir o respectivo serviço seja apta a caracterizar a sucessão trabalhista, com a consequente responsabilização do novo delegatário, tal situação propiciaria à inadimplência do antigo titular, ante a possibilidade de afastar-se da atividade sem proceder ao pagamento de eventuais débitos trabalhistas, não restando qualquer ônus a si e tão somente ao seu sucessor na serventia. Com isso, depreende-se que, caso não cumpra as obrigações trabalhistas que contraiu relativas aos prepostos que contratou, não deve o antigo titular exonerar-se de tais débitos, ficando estes a cargo do novo titular que, oportunamente, após aprovação em concurso público, assumirá a serventia.

A sucessão trabalhista produz efeitos em relação ao antigo titular, bem como ao novo empregador. No ramo jurídico-empresarial, opera-se a imediata transferência dos 
contratos trabalhistas ao novo titular. Podem, no entanto, sucessor e sucedido estabelecerem cláusula de não responsabilização do sucedido pelas verbas trabalhistas, o que - embora não tenha relevância em relação aos empregados, dadas as normas jurídicas imperativas que criam e regulam o instituto sucessório (DELGADO, 2012, p. 427) - possibilita a ação de regresso em face do sucedido, a fim de ressarcir os gastos com os contratos empregatícios anteriores à transferência.

No que tange aos serviços notariais e de registro, não sendo realizado contrato de trespasse ou qualquer operação societária, inexiste a previsibilidade dessa cláusula de não responsabilização e, com a aplicação do instituto sucessório ao caso sem que haja responsabilidade solidária ou subsidiária, ficará o novo titular da serventia com a responsabilidade plena pelos débitos trabalhistas.

No caso dos cartórios, o fundamento para a responsabilidade solidária vai para além da garantia do contrato de trabalho, impedindo a irresponsabilidade do antecessor pelos empregados que contratou, desvinculando-se quando da extinção da delegação, deixando os débitos a cargo do novo titular, aprovado em concurso público, o qual não teria qualquer opção, haja vista não haver contrato entre ambos, o que estimularia o inadimplemento das verbas trabalhistas.

\section{Considerações Finais}

Diante do estudo realizado, tendo-se analisado a problemática acerca da possibilidade ou não de aplicação do instituto da sucessão trabalhista quando há extinção da delegação na atividade notarial e registral e a assunção de novo 
responsável pela serventia extrajudicial, é possível chegar às seguintes considerações:

A atividade notarial e registral possui regramento especial no ordenamento jurídico brasileiro. Trata-se de serviço público, obrigatoriamente delegado pelo Estado a particular aprovado em concurso público, que poderá contratar empregados para desempenhar suas funções.

Diante desse vínculo de emprego, regulado pelo direito do trabalho, impende trazer-se à baila o instituto sucessório que se entende caracterizado com a ocorrência de qualquer alteração intra ou interempresarial apta a afetar os contratos de trabalho, ainda que não haja continuidade da prestação de serviço pelo obreiro.

Ocorrendo a sucessão, há substituição de empregadores, assumindo o sucessor as obrigações decorrentes dos contratos empregatícios, divergindo a doutrina quanto à responsabilidade do sucedido, se solidária ou subsidiária e, ainda, se subsidiária a do sucessor.

Ao analisar a aplicabilidade do instituto da sucessão trabalhista à atividade notarial e registral, deve-se interpretar o instituto consoante o caráter lógico-sistemático da ordem jurídica, respeitando o princípio de proteção ao obreiro, basilar do direito trabalhista, atentando-se, no entanto, às peculiaridades da atividade das serventias extrajudiciais.

Primeiramente, o tabelião ou registrador recebe a delegação do Estado e assume a titularidade do cartório, recebendo somente os livros de escrituração, o que, por si só, não caracteriza a sucessão trabalhista, pois houve aquisição originária de um direito com a investidura em concurso público, sem qualquer relação jurídica entre o antigo e o 
atual titular do cartório, havendo ruptura no contrato, pois, com a vacância, o Estado retoma a delegação e nomeia novo delegado. Assim sendo, verifica-se que não há a continuidade inerente à sucessão, tampouco a imediata transferência de direitos e obrigações entre os delegados, tão somente da função pública para a qual o sucessor prestou concurso público.

Entretanto, situação diversa verifica-se caso haja transferência do complexo de bens do antigo ao novo serventuário, pois, caso este se utilize dos mesmos bens (móveis e imóveis), dará continuidade à atividade anterior, pois o delegado, após a assunção no cartório, ciente da situação econômica da serventia, instalar-se-á no mesmo local, com os mesmos bens. Assim, é indispensável para a caracterização da sucessão trabalhista que haja assunção do patrimônio e dos bens materiais e imateriais da antecessora.

Ademais, em que pese a nova caracterização do instituto justrabalhista que entende ser desnecessária a continuidade de prestação de serviços pelo obreiro, no caso dos cartórios, não havendo continuidade da relação de trabalho na serventia após a delegação, cumpre a cada titular de cartório responsabilizar-se pelas respectivas contratações, aplicando-se por analogia entendimento afeto às concessões de serviço público. Resta, no entanto, para a caracterização do instituto sucessório in casu, mister que haja a continuidade da prestação do serviço pelo obreiro.

Outrossim, sendo caracterizada a sucessão, entende-se que o sucessor assume todas as obrigações decorrentes dos contratos empregatícios. Ocorre que o sucedido deve responder solidariamente por tais débitos, o que condiz com as normas e os princípios justrabalhistas, bem como serve de desestímulo 
à inadimplência, sendo que os dispositivos legais não isentam o sucedido de adimplir as dívidas que contraiu - mormente tratando-se dos cartórios, em que não há qualquer relação jurídica entre antigo e atual delegado. Assim, depreende-se que sucessor e sucedido respondem solidariamente pelos débitos contraídos anteriormente à sucessão, o que vai ao encontro da maior proteção ao trabalhador.

\section{Referências}

ALEXANDRE, Ricardo. Direito tributário esquematizado. 5. ed. São Paulo: Método, 2011.

ALEXANDRINO, Marcelo; PAULO, Vicente. Direito administrativo descomplicado. 16. ed. São Paulo: Método, 2008.

ARRUDA, Ana Luísa de Oliveira Nazar de. Cartórios extrajudiciais: aspectos civis e trabalhistas: sucessão trabalhista, estabilidade e regime especial, concurso público, responsabilidade civil. São Paulo: Atlas, 2008.

CURSO DE QUALIFICAÇÃO E APERFEIÇOAMENTO PARA PREPOSTOS E DEMAIS INTERESSADOS NAS ÁREAS NOTARIAIS E REGISTRAIS. Escola Superior da Magistratura/AJURIS e Escola Notarial e Registral/ENORE. Porto Alegre, 2011.

DELGADO, Maurício Godinho. Curso de Direito do Trabalho. 11. ed. São Paulo: Livraria dos Tribunais, 2012.

GARCIA, Gustavo Filipe Barbosa. Curso de Direito do Trabalho. 6. ed. Rio de Janeiro: Forense, 2012.

GONÇALVES, Vania Mara Nascimento. Direito Notarial e Registral. 1. ed. Rio de Janeiro: Forense, 2006.

KOLLET, Ricardo Guimarães. Manual do Tabelião de Notas para Concursos e Profissionais. 1. ed. Rio de Janeiro: Forense, 2008.

LENZA, Pedro. Direito Constitucional Esquematizado. 13. ed. rev. atual. e ampl. São Paulo: Saraiva, 2009. 
A (In)aplicabilidade do Instituto da Sucessão Trabalhista...

LOSANO, Mario G. Os Grandes Sistemas Jurídicos: introdução aos sistemas jurídicos europeus e extra-europeus. Tradução de Marcela Varejão; revisão da tradução de Silvana Cobucci Leite. São Paulo: Martins Fontes, 2007 (Justiça e Direito).

MARTINS, Sergio Pinto. Direito do Trabalho. 27. ed. São Paulo: Atlas, 2011.

MEIRELLES, Hely Lopes. Direito Administrativo Brasileiro. 37. ed. São Paulo: Malheiros, 2010.

NASCIMENTO, Amauri Mascaro. Iniciação ao Direito do Trabalho. 35. ed. São Paulo: Ltr, 2009.

NÁUFEL, José; THIELE, Karin. Novo Dicionário Jurídico Brasileiro. 11. ed. Rio de Janeiro: Forense, 2008.

PINTO, José Augusto Rodrigues; PAMPLONA FILHO, Rodolfo. Repertório de Conceitos Trabalhistas. v. I. São Paulo: Ltr, 2000.

RAMOS, André Luiz Santa Cruz. Direito Empresarial Esquematizado. São Paulo: Método, 2010.

130 REALE, Miguel. Lições Preliminares de Direito. 27. ed. São Paulo: Saraiva, 2002.

SENA, Adriana Goularte de. A Nova Caracterização da Sucessão Trabalhista. 1. ed. São Paulo: Ltr, 2000.

SILVA, José Afonso da. Comentário Contextual à Constituição. 7. ed. São Paulo: Malheiros, 2010.

2010.

. Curso de Direito Constitucional. 34. ed. São Paulo: Malheiros,

Submissão: 10/06/2013

Aceito para Publicação: 14/08/2013 


\title{
A Materialização do Direito Internacional Privado Brasileiro: o cancelamento da Súmula n 207 do TST
}

\author{
Materialization of Brazilian Private International \\ Law: The Cancelling of Precedent no 207 \\ of the Supreme Labor Court
}

Marília Zanchet Rosa*

Resumo: As relações de trabalho, da mesma forma como relações privadas em geral, têm assumido caráter internacional. $\mathrm{O}$ crescente fenômeno acarreta, contudo, o incremento de vulnerabilidade do trabalhador. Em nível internacional, esse desafio aumenta, especialmente porque as normas conflituais clássicas foram construídas a partir da sociedade liberal moderna, que buscava basicamente a manutenção da igualdade formal entre os indivíduos, sem preocupações de cunho material. Embora as soluções tradicionais ainda estejam presentes no Direito Internacional Privado Brasileiro, um precedente recente do Tribunal Superior do Trabalho alterou essa realidade. Assim, este trabalho tenciona analisar os efeitos dessa decisão do TST na evolução do Direito Internacional Privado Brasileiro. Na primeira parte do trabalho, será analisada a insuficiência do método clássico na proteção do empregado. A principal manifestação desse método está no elemento de conexão da lei do local da execução do contrato de trabalho, ou lex loci laboris. A segunda parte avalia a solução adotada pela jurisprudência do TST, ao cancelar a Súmula no 207 e consagrar o elemento de conexão da lei mais favorável ao empregado ou favor empregado como o principal

\footnotetext{
${ }^{*}$ Universidade Federal do Rio Grande do Sul.
} 
para as relações de trabalho internacionais. Em conclusão, aborda-se o significado desse entendimento do TST para evolução do Direito Internacional Privado Brasileiro.

Palavras-chave: Direito Internacional Privado. Direito Internacional do Trabalho. Conflitos de Lei no Espaço. Elementos de Conexão. Lei Mais Favorável ao Empregado.

Abstract: Labor relations, in the same way as private relations in general, have assumed an international character. The growing phenomenon entails, however, the increased vulnerability of the worker. On an international level, this challenge increases, especially because the Classic Conflict of Law Rules were built based on modern liberal society, whose basic aim was to maintain the formal equality between individuals, without any material concerns. Although traditional solutions are still present in Brazilian private international law, recent Supreme Labor Court precedent has changed this reality. Therefore, this paper intends to analyze the effects of this Supreme Labor Court decision in the Brazilian Private International Law. In the first part of this paper will be analyzed the insufficiency of the classical method in the employee protection. The main expression of this method lies in the connecting element of the law of the place of the labor contract, or lex loci laboris. The second part evaluates the solution adopted by the case law of the TST to cancel precedent $\mathrm{n}^{\mathrm{o}}$. 207 and consecrate the connecting element of the law most favorable to the employee, or employee favor, as the main connecting element for international labor relations. Concluding, the meaning of this understanding of the Supreme Labor Court decision for the evolution of Brazilian Private International Law is discussed.

Keywords: Private International Law. International Labor Law. Conflict of Law Rules. Connecting Elements. Law Most Favorable to the Employee. 


\section{Introdução}

O fenômeno da globalização vem produzindo significativas alterações na sociedade nos dois últimos séculos ${ }^{1}$, gerando uma crescente internacionalização das relações privadas $^{2}$. Consequentemente, houve um aumento do intercâmbio de trabalhadores entre os países ${ }^{3}$, ganhando relevo o Direito Internacional Privado do Trabalho.

A particularidade dos conflitos de leis envolvendo trabalhadores está nas leis em conflito possuírem um papel social diferente, devendo atribuir assistência jurídica e proteção econômica ao trabalhador ${ }^{5}$. Assim, embora as normas de conflito, em si, não apresentem nenhuma particularidade, a solução delas decorrente requer cuidadosa atenção ${ }^{6}$.

1 A respeito do impacto do fenômeno da globalização no Direito, FARIA, José Eduardo. O direito na economia globalizada. São Paulo: Malheiros, 1999.

2 FERNÁNDEZ ARROYO, Diego P. El derecho internacional privado en el inicio del siglo XXI. In: MARQUES, Cláudia Lima; ARAÚJO, Nádia de (Org.) O novo direito internacional: estudos em homenagem a Erik Jayme. Rio de Janeiro: Renovar, 2005. p. 89-110. Também, a respeito do tema: FRADERA, Véra Maria Jacob de. O direito dos contratos no século XXI: a construção de uma noção metanacional de contrato decorrente da globalização, da integração regional e sob influência da doutrina comparatista. In: DINIZ, Maria Helena; LISBOA, Roberto Senise. O direito civil no século XXI. São Paulo: Saraiva, 2003. p. 500-503.

3 CHAPARRO, Verônica Zárate. O Estrangeiro à Luz do Direito Internacional e do Direito Brasileiro: Breves Considerações. In: DEL'OLMO, Florisbal de Souza (Coord.). Curso de Direito Internacional Contemporâneo: estudos em homenagem ao professor doutor Luís Ivani Amorim de Araújo pelo seu 80ㅜaniversário. Rio de Janeiro: Forense, 2003.

4 Acerca da construção do conceito dessa disciplina, RUSSOMANO. Gilda Maciel Corrêa Meyer. Direito Internacional Privado do Trabalho. Rio de Janeiro: Forense, 1979.

5 RUSSOMANO, Gilda Maciel Corrêa Meyer. Os Conflitos Espaciais de Leis no Plano das Relações Trabalhistas. José Konfino: Rio de Janeiro, 1964. p. 85.

6 RUSSOMANO, Os Conflitos, op. cit., p. 85. 
Nesse sentido, vale um breve apanhado sobre o desenvolvimento do $\mathrm{DIPr}^{7}$ Brasileiro na atualidade ${ }^{8}$. A disciplina foi codificada em 1917, com a edição da Introdução ao Código Civil. Essa lei, promulgada juntamente com o Código Civil de 1916, adotou, como regra de conexão relativa à capacidade, a lei da nacionalidade da pessoa envolvida, na linha dos países europeus, mas na contramão dos demais países latino-americanos que, em sua maioria, optaram pela regra do domicílio.

Em 1942, com a edição da Lei de Introdução ao Código Civil, Decreto-Lei n. ${ }^{\circ}$ 4.687/42, o DIPr Brasileiro sofre uma profunda alteração, objetivando adequar-se às decorrências da imigração, à semelhança do que ocorria com os demais países latino-americanos, que adotavam a regra domiciliar. Observou-se, naquele momento, uma clara tentativa de modernização, não somente do DIPr Brasileiro, como também de todo o sistema de aplicação de normas jurídicas ${ }^{9}$.

Ao final do século $\mathrm{XX}$, é editada a Constituição Federal de 1988. Nesse momento, o país demonstrou uma abertura para a questão internacional e de proteção dos direitos humanos nunca antes observado, conforme observa-se do seu art. $4^{\mathrm{o} 10}$. A doutrina realça essa opção como uma

7 DIPr será utilizado para abreviar Direito Internacional Privado.

8 DOLINGER, Jacob et al. O DIP no Brasil no século XXI. Revista Mexicana de Derecho Internacional Privado, número especial, 2000. p. 81.

9 DOLINGER et al. O DIP, op. cit., p. 82. Citam-se dois dos principais projetos de lei de introdução ao Código Civil desenvolvidos no Brasil, um deles de autoria de Haroldo Valladão, de 1963, e outro de autoria Jacob Dolinger, de 1995. Nenhum deles, contudo, conseguiu aprovação no Congresso Nacional.

10 “Art. 4⿳. A República Federativa do Brasil rege-se nas suas relações internacionais pelos seguintes princípios: I - independência nacional; II - prevalência dos direitos humanos; III - autodeterminação dos povos; IV - não-intervenção; V igualdade entre os Estados; VI - defesa da paz; VII - solução pacífica dos conflitos; VIII - repúdio ao terrorismo e ao racismo; IX - cooperação entre os povos para o progresso da humanidade; $X$ - concessão de asilo político. Parágrafo único. A 
orientação internacionalista jamais vista na história constitucional brasileira ${ }^{11}$.

Entretanto, as mudanças promovidas pelas novas diretrizes constitucionais não foram observadas na legislação de DIPr. A última reforma legislativa por que passou a disciplina foi na edição da Lei n⿳o 12.376/10, cuja função foi alterar a denominação da antiga LICC $^{12}$, agora chamada de Lei de Introdução às Normas do Direito Brasileiro ${ }^{13}$. Dessa forma, como não houve alterações substanciais, permanece a crítica à disciplina legislativa da matéria que vinha se fazendo anteriormente ${ }^{14}$.

Nesse contexto, ganha importância o cancelamento da Súmula no 207 do Tribunal Superior do Trabalho, em abril de 2012. Editada na década de 1980, determinava que "[...] $a$ relação jurídica trabalhista é regida pelas leis vigentes no país da prestação do serviço e não por aquelas do local da contratação" ${ }^{\prime 15}$.

A mudança na jurisprudência do $\mathrm{TST}^{16}$ demonstra a evolução Corte na área dos conflitos de lei trabalhistas no

República Federativa do Brasil buscará a integração econômica, política, social e cultural dos povos da América Latina, visando à formação de uma comunidade latino-americana de nações."

${ }^{11}$ PIOVESAN, Flávia. Direitos Humanos e Direito Constitucional Internacional. 5. ed., São Paulo: Max Limonad, 2002. p. 62.

${ }^{12}$ LICC serve para abreviar Lei de Introdução ao Código Civil.

${ }^{13}$ FRANCO FILHO, Georgenor de Souza Franco. Contratos Internacionais do Trabalho. Revista Síntese Trabalhista e Previdenciária, v. 23, n. 265, p. 30-43, jul. 2011. p. 31.

14 JUNIOR, Augusto Jaeger. Europeização do Direito Internacional Privado - Caráter Universal da Lei Aplicável e outros Contrastes com o Ordenamento Jurídico Brasileiro. Curitiba: Juruá, 2012. p. 24.

15 Acerca das condições do nascimento da Súmula no 207 do TST, ROCHA. Osíris. Contrato Internacional de Trabalho: conseqüências brasileiras. Revista LTr: Legislação do Trabalho, São Paulo, v. 58, n. 5, maio 1994. p. 531.

${ }^{16}$ TST será usado para abreviar Tribunal Superior do Trabalho. 
espaço. $\mathrm{O}$ fenômeno da chamada materialização do $\operatorname{DIPr}^{17}$, ocorrido principalmente na Europa, também demonstra seus efeitos na jurisprudência trabalhista brasileira.

O cancelamento da Súmula nº 207 originou-se do julgamento de caso envolvendo um trabalhador contratado em 1982 pela Braspetro Oil Service Company (Brasoil), subsidiária da Braspetro Petrobras Internacional S.A., para trabalhar como Guindasteiro em plataforma petrolífera nas águas na costa de Angola. O contrato foi rescindido em 1998, nos termos da legislação local, e em seguida o empregado ajuizou, com êxito, ação trabalhista em que pedia a aplicação da legislação brasileira, que lhe era mais favorável - a exemplo da prescrição trabalhista brasileira, que é de dois anos, enquanto a angolana é de apenas um ano. Inconformadas com a manutenção da sentença, as empresas recorreram à instância superior, buscando a aplicação da legislação territorial, que define o local da prestação de serviço para a resolução do litígio. Nesse julgamento, o Tribunal, após avaliar a evolução do DIPr europeu e se valendo dos elementos de conexão mais atuais do que os presentes na legislação brasileira, decidiu por afastar o princípio da territorialidade ${ }^{18}$, adotado pela jurisprudência até então vigente no TST.

${ }^{17}$ Vale destacar o termo fundamentalização, utilizada por Diego Fernández Arroyo quando refere-se às mudanças por que tem passado o DIPr, a fim de se tornar um instrumento para a realização dos direitos fundamentais. Nesse sentido, FERNÁNDEZ ARROYO, Diego Fernández. Prefácio. In: JUNIOR, Augusto Jaeger. Europeização do Direito Internacional Privado - Caráter Universal da Lei Aplicável e outros Contrastes com o Ordenamento Jurídico Brasileiro. Curitiba: Juruá, 2012. p. 10.

${ }^{18}$ O julgamento do RR-219000-93.2000.5.01.0019, Rel. Ministra Maria Cristina Irigoyen Peduzzi, pela Subseção I Especializada em Dissídios Individuais, em 22 de setembro de 2011, deu origem ao cancelamento da Súmula nº 207, por meio da Res. 181 de 23 de abril de 2012 do TST. 
Dessa forma, o presente artigo busca aferir uma possível evolução do DIPr brasileiro, por meio da proteção do empregado, a demonstrar a insuficiência da disciplina clássica. Para isso, num primeiro momento, será analisada a solução dada pelo clássico elemento de conexão da lex laboris ou lex loci executionis, adotado pela Súmula no ${ }^{2}$ 207. E, posteriormente, será verificada a solução de que se valeu o TST para resolver o caso citado, por meio do elemento de conexão do favor empregado.

\section{A Insuficiência do Método Clássico na Proteção Internacional do Empregado}

O liberalismo jurídico, calcado na lógica racional-formal, originou o sistema do DIPr clássico, como um conjunto de normas geralmente conflituais, indiretas. Essas normas não solucionam a questão jurídica em si, apenas indicam o direito interno aplicável, sendo assim, classificadas como normas instrumentais ${ }^{19}$ ou normas de colisão ${ }^{20}$, ou, ainda, normas de superdireito ${ }^{21}$. Dessa forma, diante de uma situação que apresente um ou mais elementos de estraneidade ${ }^{22}$, a regra conflitual é autorizada a atuar, conduzindo

${ }^{19}$ DOLINGER, Jacob. Direito internacional privado: parte geral. 7 ed. Rio de Janeiro: Renovar, 2003. p. 51-52.

${ }^{20}$ GOLDSCHMIDT, Werner. Sistema y filosofía del derecho internacional privado. Barcelona: Bosch, 1948. p. 120.

${ }^{21}$ BATALHA, Wilson de Souza Campos. Tratado elementar de direito internacional privado: parte geral. São Paulo: Revista dos Tribunais, 1961. v. 1. p. 85.

${ }^{22}$ Na lição de Elhoueiss (ELHOUEISS, Jean-Luc. L'élément d'extranéité préalable en droit international privé, Journal du Droit International, n. 1, p. 39-85, jan./mar. 2003. p. 40), a estraneidade é a qualidade daquilo que é estrangeiro. Contudo, o DIPr não apresenta uma definição precisa de estraneidade. Apenas destaca-se que, na presença de uma relação de direito privado com ou mais elementos alienígenas, afasta-se a aplicação de regras substanciais de direito interno em benefício das regras de DIPr. 
à descoberta, por meio de um elemento de conexão, da lei aplicável à relação jurídica de caráter internacional.

O sistema clássico foi construído a partir de uma lógica que buscava o que se denomina de "respeito ao conjunto legislativo" ${ }^{23}$. A ideia subjacente às regras aplicáveis a uma situação jurídica está em criar um conjunto coerente, de sorte que uma lei, e apenas uma, deve ser aplicada à situação, sob pena de introduzir um desequilíbrio não desejado entre as partes interessadas na causa. Ao contrário, porém, as regras de conflito, mesmo as mais afinadas, podem traduzir um despedaçamento das situações jurídicas conectadas a mais de sistema jurídico, isto é, as próprias regras de DIPr, eventualmente, criam inúmeras incoerências ${ }^{24}$.

De qualquer forma, no âmbito dessas regras conflituais, podem ser encontrados diversos métodos de indicação da lei aplicável, os quais podem ser classificados a partir de um caráter mais ou menos radical de aceitação do direito advindo dos sistemas jurídicos estrangeiros. Num primeiro estágio, o juiz, destinatário da regra de DIPr, aplica apenas a sua própria lei ou a chamada lex fori ${ }^{25}$. A seguir, enuncia-se o método unilateral. A partir de uma análise da lei do foro, determinam-se as situações internacionais às quais essa lei será aplicada. Dessa forma, por exemplo, ao divórcio de dois estrangeiros, mas domiciliados no país, será aplicada a lei do foro.

${ }^{23}$ AUDIT, Bernard. Le droit international privé a fin du XXe siècle: progrès ou recul. Revue International de Droit Comparé, n. 2, p. 421-448, avril/juin 1998. p. 421.

${ }^{24}$ AUDIT, Le droit, op. cit., p. 421-422.

${ }^{25}$ DROZ, G.A. L. Regards sur le droit international privé comparé. Recueil des Cours de l'Académie de Droit International de La Haye, Hague, v. 4, n. 229, p. 13-423, 1991. p. 29. 
Essas regras de conflito prevaleceram até a Primeira Guerra Mundial ${ }^{26}$. Assim, em que pese as soluções do DIPr venham se alterando, a maioria das normas brasileiras é, ainda, pautada por esse método. Nesse sentido, analisam-se a estrutura dessas normas no âmbito da contratação internacional e as soluções para a questão do empregado. Verifica-se, dessa forma, a insuficiência dessa lógica formal para proteger o trabalhador que vem a se sujeitar a um ordenamento jurídico diverso daquele de origem.

\subsection{Normas Clássicas}

Primeiramente, deve-se fazer uma breve análise acerca do resultado da aplicação dos critérios objetivos do lugar de conclusão do contrato ou do lugar de execução do contrato. Ambos os critérios são considerados elementos de valor geral ${ }^{27}$, na lição de Henri Batiffol ${ }^{28}$.

${ }^{26}$ OVERBECK, Alfred E. von. Les questions générales du droit international privé à la lumière des codifications récents. Recueil des Cours de l'Academie de Droit International de la Haye, Hague, v. 3, n. 176, 1983. p. 73.

${ }^{27}$ Conforme referem Elsa Dias de Oliveira (OLIVEIRA, Elsa Dias. A protecção dos consumidores nos contratos celebrados através da internet: contributo para uma análise numa perspectiva material e internacional privatista. Coimbra: Almedina, 2002. p. 187) e Fausto Pocar (POCAR, Fausto. La protection de la partie faible em droit international privé. Recueil des Cours de l'Academie de Droit International de la Haye, 1984, Dordrecht/Boston/London, t. 188. p. 339-417, 1986. p. 386), são vários os critérios objetivos que podem determinar a legislação aplicável aos contratos, tais como a língua na qual o contrato está redigido, a escolha do foro ou tribunal arbitral, a aplicação de conceitos jurídicos de uma ordem jurídica determinada, as negociações das partes no período de formação do contrato, a lei escolhida para reger contratos anteriormente celebrados, a nacionalidade ou a residência comum dos contratantes. Já Amílcar de Castro (CASTRO, Amílcar. Direito internacional privado. 5. ed. Rio de Janeiro: Forense, 1997. p. 433-434) elenca outros possíveis critérios, tais como o ius patriae; ou domicilii, do credor, ou do devedor, ou, ainda, o direito conveniente a cada espécie de contrato ou o eleito pelas partes.

${ }^{28}$ BATIFFOL, Henri. Traité élémentaire de droit international privé. 2. ed., Paris: LGDJ, 1955. p. 635. 
São dois os argumentos apontados em favor da utilização da lex loci contractus ${ }^{29}$, um de fundo teórico e outro de caráter prático. Por um lado, apresenta-se bastante coerente indicar a lei do local onde as partes dão origem ao contrato como a competente para regê-lo. Por outro, ao favorecer a segurança jurídica, a lex loci contractus também se mostra bastante eficiente: o lugar de nascimento do contrato é apenas um e de fácil determinação. Dessa forma, a lei que está em vigor ou que se aplica ao caso será mais facilmente consultada pelas partes ${ }^{30}$.

Contudo, essas supostas vantagens são fortemente refutadas $^{31}$. Mostra-se difícil qualificar o lugar da conclusão

${ }^{29}$ O critério do local da conclusão dos contratos é adotado na legislação brasileira de DIPr através do art. $9^{\circ}$ da Lei de Introdução: "Para qualificar e reger as obrigações, aplicar-ser-á a lei do país em que se constituírem. $\S 1^{\circ}$ Destinando-se a obrigação a ser executada no Brasil e dependendo de forma essencial, será esta observada, admitidas as peculiaridades da lei estrangeira quanto aos requisitos extrínsecos do ato. $\S 2^{\circ}$ A obrigação resultante do contrato reputa-se constituída no lugar em que residir o proponente." (grifo nosso) Contudo, apesar da regra geral brasileira ser a lex loci contractus, a regra relativa à execução tem tido preponderância na jurisprudência pátria (ARAUJO, Nádia de. Contratos internacionais: autonomia da vontade, Mercosul e convenções internacionais. 3. ed. Rio de Janeiro: Renovar, 2004. p. 123-127), a partir da interpretação de que à lei do local da constituição se somam as exigências da lei do local de sua execução. E como efetivamente é mais comum ocorrerem litígios em razão do contrato no local de sua execução, por ser este quase sempre o lugar onde o devedor tem seu domicílio, bens e estabelecimentos comerciais, podendo mais facilmente honrar seus compromissos, a lei brasileira, por ser o local da execução, é invariavelmente a lei aplicável.Vale destacar, ainda, o entendimento de Dolinger e Tibúrcio (DOLINGER et al., O DIP, op. cit., p. 79) sobre a escassez jurisprudencial sobre casos de conflito de leis, a qual é creditada principalmente à mudança do elemento de conexão relativo ao estatuto pessoal, introduzido pela LICC de 1942, que passou da regra da nacionalidade para a regra do domicílio. Assim, o Brasil, país de imigrantes, visando a uma integração plena entre os seus habitantes e a uma maior praticidade, viu diminuir sensivelmente as hipóteses de aplicação de lei estrangeira pelo Judiciário.

${ }^{30}$ BATIFFOL, Traité, op. cit., p. 636. Vale referir a doutrina de Amílcar de Castro (CASTRO, Direito, op. cit., p. 444) relacionando a origem do sistema da lex loci contractus ao trabalho dos pós-glosadores.

${ }^{31}$ Em regra, os autores (ARAÚJO, Contratos, op. cit., p. 121-122; BOGGIANO, Antonio. The contribution of the Hague conference to the development of private 
do contrato, quando os contratos são concluídos à distância, dependendo-se de se tratar da lex fori ou da lex causae ${ }^{32}$. Também se refere o papel do acaso na contratação internacional como argumento contrário à lex loci contractus. Muitas vezes o lugar de nascimento do contrato apresenta-se fortuito ou acidental para constituir um critério que obedeça aos interesses das partes envolvidas ${ }^{33}$. Nesse sentido, cita-se a experiência jurisprudencial, a qual demonstra que, na grande maioria dos contratos internacionais, o local onde são concluídos os negócios corresponde a grandes centros, nos quais os contratantes não apresentam interesse permanente ${ }^{34}$. Trata-se apenas de locais de encontro, cujos objetivos que levam os contratantes a eles são diferentes daqueles decorrentes dos pactos que lá realizam. Quanto à facilidade de se obter informações acerca da lei aplicável ao contrato, o autor francês não a considera relevante ${ }^{35}$. De fato, na maioria dos casos, os contratantes não costumam questionar a legalidade dos pactos, nem sequer consultam qualquer legislação a respeito. Dessa forma, caso algum conflito venha a se verificar, será muito mais adequado aplicar a legislação que corresponda aos reais interesses das

\footnotetext{
international law in Latin America: universality and genus loci. Recueil des Cours de l'Academie de Droit International de la Haye, Hague, n. 233, p. 103-266, 1993. p. 134; OLIVEIRA, A protecção, op. cit., p. 185) costumam criticar os critérios objetivos de determinação da lei aplicável, ao compará-los à segurança e à previsibilidade proporcionada pelo critério subjetivo, ou seja, pela vontade das partes.

${ }^{32}$ LOUIS-LUCAS, Pierre. La distinction du fond et de la forme dans le règlement des conflits de lois. In: MAURY, Jacques (Org.). Mélanges offerts Jacques Maury. t. 1: Droit international privé et public. Paris: Dalloz, 1960. p. 175-205.

${ }_{33}$ Amílcar de Castro (CASTRO, Direito, op. cit., p. 445) traz o exemplo de um brasileiro de passagem pelos Estados Unidos, onde se depara com um amigo argentino, também a passeio, e nesse encontro fortuito fazem um contrato, que ficará então sendo regulado pelo direito norte-americano.

34 As referências à jurisprudência são trazidas por Henri Batiffol (BATIFFOL, Traité, op. cit., p. 637-638).

${ }^{35}$ BATIFFOL, Traité, op. cit., p. 638.
} 
partes. Ademais, caso estiverem realmente interessadas em verificar a legalidade de sua convenção, não se importarão em verificar qualquer lei. Assim, esse argumento acaba se tornando válido apenas para hipóteses muito raras ${ }^{36}$.

Segundo Fausto Pocar, a conexão do lugar da celebração do contrato não favorece a segurança jurídica. Ocorre que são grandes as dificuldades de qualificação ${ }^{37}$ do lugar de conclusão do contrato nos contratos entre ausentes ${ }^{38}$, maioria nos contratos internacionais. Não há homogeneidade entre os sistemas jurídicos de direito material quanto ao local de conclusão entre ausentes: se a qualificação decorrer da lex fori, será o juiz do conflito que a determinará, já se decorrer da lex causae, há dificuldade de se determinar a lei que rege o contrato, já que depende justamente da determinação do lugar de conclusão.

Relativamente ao lugar da execução do contrato $^{39}$, observam-se inicialmente suas apontadas virtudes, tais como

${ }^{36}$ BATIFFOL, Traité, op. cit., p. 638.

37 Na lição de Elhoueiss (ELHOUEISS, Jean-Luc. Retour sur la qualification lege causae en droit international privé. Journal de Droit International, n. 2, p. 281-313, avril/juin 2005. p. 285), a qualificação constitui o ponto de partida de todo o raciocínio do DIPr clássico. Para o autor, porém, o conceito de categoria jurídica e de qualificação está longe de ser mecânico no âmbito do direito privado. Assim, embora deva se reconhecer o papel fundamental da qualificação, certamente não constitui um problema devidamente adaptado aos fundamentos formais do DIPr Clássico.

38 Autores brasileiros tradicionais, tais como Clóvis Beviláqua (BEVILÁQUA, Clóvis. Princípios elementares de direito internacional privado. Campinas: RED, 2002. p. 206), já se deparavam com tais problemas, conforme trecho a seguir: "Adotando-se o sistema da expedição, [...] o contrato se supõe firmado no momento em que a aceitação é expedida, o lugar do contrato é justamente aquele de onde a aceitação é expedida. Videtur consumari contractus in loco ubi acceptatio facta est, quia illie utriusque consensus coivit. Se o sistema adotado for o da cognição, como a convenção somente se forma depois que o ofertante politicamente toma conhecimento da aceitação, é no domicílio dele que se encontra o lugar do contrato".

${ }^{39} \mathrm{Na}$ América Latina, em especial nos países do Mercosul, Lauro Souza Júnior (SOUZA JÚNIOR, Lauro da Gama e. Os princípios do Unidroit relativos aos 
estar a lex loci executionis materialmente conectada com os interesses das partes. Com efeito, há uma tendência secular no DIPr em localizar as relações jurídicas pelo elemento que manifestam exteriormente ou, também dito, materialmente $e^{40}$ : daí a preponderância, por exemplo, do estatuto real, ou forum rei sitae, em relação aos bens, ou do lex loci delicti em relação aos atos ilícitos.

Por outro lado, a caracterização do lugar da execução do contrato como critério geral resta afastada quando se verificam situações nas quais o contrato é executado em vários lugares, ou quando tal lugar se apresenta indeterminado ${ }^{41}$. Disso decorre a construção do conceito do lugar da execução principal (lieu d'exécution principal ${ }^{42}$ ), que, no caso da venda de bens móveis, pode ser o lugar do pagamento do preço, por exemplo. Dessa forma, a previsibilidade e a segurança dessa solução acabam igualmente mitigadas. Assim, excetuando-se as hipóteses nas quais a jurisprudência acaba desenvolvendo

contratos comerciais internacionais e sua aplicação nos países do Mercosul. In: RODAS, João Grandino (Org.). Contratos internacionais. São Paulo: Revista dos Tribunais, 2002. p. 436-439.) destaca que o critério da lei do lugar da execução é adotado na Argentina, nos artigos 1.205 a 1.216 do Código Civil; no Uruguai, cuja previsão encontra-se no art. 2.399 do Código Civil e na Lei 10.084/41; por fim, no art. 297 do Código Civil paraguaio. No mesmo sentido, A insuficiente proteção do consumidor nas Normas de Direito Internacional Privado - Da necessidade de uma Convenção Interamericana (CIDIP) sobre Lei Aplicável a Alguns Contratos Relações de Consumo. In: MARQUES, Cláudia Lima. ARAÚJO, Nádia de (Org.). O Novo Direito Internacional - estudos em homenagem a Erik Jayme. Rio de Janeiro, São Paulo e Recife: Renovar, 2005. p. 171-172. Segundo Pocar (POCAR, La protection, op. cit., p. 386-387), a lei do lugar de execução do contrato é bastante frequente na prática legislativa e jurisprudencial, constituindo-se o critério decisivo para a determinação da lei aplicável.

${ }^{40}$ BATIFFOL, Traité, op. cit., p. 638.

${ }^{41}$ BATIFFOL, Traité, op. cit., p. 638.

${ }^{42}$ BATIFFOL, Traité, op. cit., p. 639. 
corretivos para os critérios rígidos ${ }^{43}$, o contrato será submetido a legislações diversas, cuja harmonização pode apresentar problemas delicados ${ }^{44}$.

\subsection{Lex Loci Laboris}

A legislação comparada, a doutrina e a jurisprudência, de forma tradicional, têm consagrado, com pequenas exceções, a lex loci laboris ou lex loci executionis como princípio dominante para a solução dos conflitos de leis trabalhistas no espaço nas fases da execução e da cessação do contrato de trabalho ${ }^{45}$. A autora Gilda Russomano afirma que a solução dos conflitos entre leis aplicáveis ao contrato de trabalho é observada pela aplicação Lex loci executionis, pois o lugar da execução surge como elemento relevante ${ }^{46}$.

No Brasil, o critério da lei do local da execução do contrato, considerando-se a relação de trabalho, encontra-se como a solução dos tribunais trabalhistas brasileiros, a ponto de ter sido editada a Súmula no 207 do TST. Atingiu-se esse critério pela conjugação daqueles constantes nos arts. $9^{\circ}$, $\$ 1^{\circ}$, da Lei de

${ }^{43}$ Batiffol cita (BATIFFOL, Traité, op. cit., p. 638-639) uma decisão da Corte Federal Suíça, datada de 10 de junho de 1952, R. 1953.390, na qual foi estabelecida como lei aplicável ao contrato aquela do local de execução da prestação característica da obrigação, a fim de solucionar a diversidade de leis passíveis de aplicação, em virtude do lex loci executionis. Nesse sentido, destaca-se que o desenvolvimento do princípio da autonomia da vontade na definição da lei aplicável às relações privadas internacionais encontra relação com o desenvolvimento do princípio da proximidade (atualmente muito utilizado para determinar a legislação aplicável quando da ausência de definição expressa - art. 9 da CIDIP V, por exemplo).

${ }_{44}$ No mesmo sentido, OLIVEIRA, Protecção, op. cit., p. 195.

45 SÜSSEKIND. Arnaldo. Conflitos de Leis do Trabalho. Rio de Janeiro: Freitas Bastos, 1979. p. 26.

${ }^{46}$ RUSSOMANO, Direito, op. cit., p. 100. 
Introdução e 651 da CLT. O primeiro manda aplicar a lei brasileira aos contratos executados no país, e o segundo estabelece a competência da Justiça do Trabalho brasileira a partir do lugar onde a prestação de serviços ocorre, ainda que o empregado tenha sido contratado noutro local ou no estrangeiro ${ }^{47}$.

Ainda, o Código de Bustamante, ratificado pelo Brasil e promulgado pelo Decreto $\mathrm{n}^{\mathrm{o}} \mathbf{1 8 . 8 7 1 / 2 9}$, apresenta uma regra específica acerca dos contratos de trabalho. Em seu art. 198 estabelece ser territorial a legislação sobre acidentes de trabalho e proteção social do trabalhador ${ }^{48}$. Dessa forma, o referido dispositivo foi sendo igualmente usado no âmbito da Justiça do Trabalho para solucionar os conflitos internacionais envolvendo a proteção do empregado.

Importante lembrar que o Código de Bustamante ${ }^{49}$ somente se aplica aos casos em que haja interesses de nacionais dos Estados Americanos que o ratificaram, não sendo observado se houver interesse de nacionais de um mesmo país. A lógica é que, nessas situações, aplica-se a lex loci laboris, entre vários elementos de conexão, porque o Estado de origem não iria permitir que seus nacionais se submetessem a condições de trabalho inferiores ao padrão mínimo por ele determinado ${ }^{50}$. Essa situação, contudo, pode nem sempre ser observada.

Assim, o art. 9 da atual Lei de Introdução às Normas de Direito não teria revogado o art. 198 do Código de Busta-

\footnotetext{
${ }^{47}$ ROCHA, Contrato, op. cit., p. 531.

${ }^{48}$ MARTINS, Sérgio Pinto. Origens e Fundamentos do Direito Internacional Privado e Relações com o Direito do Trabalho. Revista do Tribunal Regional do Trabalho da $8^{a}$ Região. Belém, v. 30, n. 58, p. 107-127, jan./jun. 1997. p. 114.

${ }^{49}$ Relatos sobre a obra desenvolvida pelo jurista cubano Antonio Sánchez y Bustamante em DOLINGER, Direito, p. 80-81.

${ }^{50}$ MARTINS, Origens, op. cit., p. 114-115.
} 
mante, pois a lei geral não revoga a especial ${ }^{51}$. Logo, o atrito entre os arts. 9º da Lei de Introdução e 198 do Código de Bustamante é apenas aparente, pois o primeiro está vinculado, ostensivamente, no caso, ao art. 17 da mesma norma, que consagra o princípio da ordem pública e, em nome dele, imobiliza a lei estrangeira que seja invocada pela parte interessada ${ }^{52}$.

A lei do lugar da execução do contrato também constitui elemento de conexão na disciplina dos contratos internacionais de trabalho na Europa. Inicialmente previsto no Convênio ou Convenção de Roma, de 1980, atualmente substituído pelo Regulamento Roma ${ }^{53}$, a lex loci laboris continua vigente, juntamente com outros critérios de conexão.

Entretanto, a solução da Súmula no 207 do TST não resolvia todos os problemas jurídicos existentes por meio da aplicação da lex loci laboris ${ }^{54}$. O TST alterou sua posição por meio da percepção de que a lei do lugar da execução do contrato nem sempre garantia a proteção que a condição de vulnerável do empregado exige.

No caso que gerou a mudança na postura da Corte em análise, a aplicação da lei angolana, que obedece ao elemento de conexão próprio do local da execução do contrato, impediria o empregado de ingressar com a demanda. O prazo prescricional para interposição da demanda trabalhista é de apenas um ano naquele país africano, enquanto no Brasil é de

${ }^{51}$ MARTINS, Origens, op. cit., p. 115.

${ }^{52}$ Nesse sentido, SPIES, André Luis. Reflexões Trabalhistas acerca do Direito Internacional Privado. Um Pressuposto Científico para Futura Harmonização Legislativa no MERCOSUL. Revista de Jurisprudência Trabalhista do Rio Grande do Sul, ano XV, n. 172, Porto Alegre: HS Editora, p. 111-121, abr. 1998. p. 118.

${ }^{53}$ Regulamento (CE) n. ${ }^{\circ}$ 593/2008, de 24 de julho de 2008. Acerca do tema, JAEGER, Europeização, p. 68-70.

${ }^{54}$ MARTINS, Origens, op. cit., p. 116. 
dois, nos termos da Constituição Federal ${ }^{55}$. Ainda, na legislação daquele país, restou comprovado não haver previsão de pagamento de qualquer verba ao término do contrato de emprego por mútuo consentimento, sendo permitido o pagamento de compensação monetária pelo não gozo de férias ${ }^{56}$. Em comparação com o padrão de proteção dado pela legislação nacional sobre verbas rescisórias e férias, esse empregado não estaria protegido ${ }^{57}$.

Dessa forma, embora o papel localizador da norma de conexão decorrente da Súmula no 207 do TST estaria desempenhado satisfatoriamente, a proteção da parte mais fraca restaria esquecida. Assim, o TST passou a procurar novas soluções.

\section{A Solução por Meio da Materialização do Direito Internacional Privado}

Dentro do contexto de mudança do DIPr, a transposição de uma política de defesa do contratante mais fraco para uma dimensão jusprivatista internacional nem sempre encontrou apoio unânime da doutrina, por se acreditar que a função do DIPr deveria manter distinta daquela desempenhada pelo direito material ${ }^{58}$. Referem os doutrinadores do Mercosul que, após a década de 1960, caminhou-se no sentido de repensar o método e a ideia de justiça no DIPr ${ }^{59}$.

\footnotetext{
${ }_{55}$ Art. $7^{\circ}$, XXIX, da Constituição Federal.

56 TST, RR-219000-93.2000.5.01.0019, Rel. Ministra Maria Cristina Irigoyen Peduzzi, I Especializada em Dissídios Individuais, julgado em 22 de setembro de 2011.

${ }^{57}$ A proteção à despedida sem justa causa e às férias são direitos fundamentais dos empregados nos termos do art. $7^{\circ}$, I e XVII, da Constituição Federal.

${ }^{58}$ OLIVEIRA, A protecção..., p. 179.

${ }^{59}$ FRESNEDO DE AGUIRRE, Cecilia. Aspectos generales del sector del derecho aplicable. In: FERNÁNDEZ ARROYO, Diego P. (Org.). Derecho internacional privado de
} 
$\mathrm{O}$ autor Bernard Audit ${ }^{60}$ refere que uma tendência "de fundo" passou a ser observada no âmbito do DIPr. Concernente ao método clássico, houve um recuo da abstração que caracterizava a regra de conflito. Iniciou-se um movimento de busca por um meio termo ou uma alternativa entre a justiça dos conflitos e a justiça do direito material, entre a certeza e a flexibilidade, numa coexistência entre as regras e a abordagem material ${ }^{61}$. Assim, as normas conflituais passaram a perseguir determinados objetivos materiais. E a proteção do trabalhador parte dessa mesma lógica.

A regra de conflito apresenta-se na atualidade como um instrumento de garantia a certos padrões de proteção nas relações privadas internacionais. A busca é pela satisfação de interesses materiais ou governamentais, além de prover as necessidades do comércio e da própria justiça nas relações internacionais. Frisa Audit' ${ }^{62}$, porém, que essa preocupação com a justiça aparece mais claramente na doutrina do que na análise das decisões da Corte de Cassação francesa, por exemplo. Atribui essa atitude ao apego do juiz à lei, mas acredita na mudança dessa realidade nos próximos anos.

No direito brasileiro, há exemplos de manifestação desse fenômeno, tanto na legislação quanto na jurisprudência. Em que pese seja possível identificar exemplo até mesmo na Constituição Federal, no âmbito das relações de trabalho, houve uma evolução sensível no tema. Como a proteção do trabalhador exige um constante esforço interpretativo

los estados del MERCOSUR: Argentina, Brasil, Paraguay, Uruguay. Buenos Aires: Zavalia, 2003. p. 300.

${ }^{60}$ AUDIT, Le droit, op. cit., p. 422.

${ }^{61}$ AUDIT, Le droit, op. cit., p. 423.

${ }^{62}$ AUDIT, Le droit, op. cit., p. 438. 
para a garantia desses direitos ${ }^{63}$, facilita-se essa evolução na jurisprudência.

\subsection{Normas de Conexões Abertas}

As chamadas cláusulas de exceção, ou também chamadas normas de conexões abertas têm sido usadas como corretivo das normas clássicas. Igualmente indiretas, exigem um caráter material e tópico para sua concretização. Representam a tendência a uma ligação entre o critério rígido e a solução flexível: levam em consideração as particularidades do caso, caracterizando uma novidade nos sistemas continentais ${ }^{64}$.

São duas as espécies de relações que privilegiam esse tipo de norma de caráter corretivo: os contratos com consumidores ${ }^{65}$ e os contratos de trabalho. Ambos são baseados em relações especiais, que exigem a proteção a uma parte contratante considerada. A utilização de conexões abertas permite contornar a dificuldade de se criar norma específica de proteção da parte mais fraca. Da mesma forma como a exceção de ordem pública, as cláusulas corretivas requerem uma concretização. Ao contrário da ordem pública, contudo, elas buscam corrigir a conexão, não o resultado material ${ }^{66}$.

\footnotetext{
${ }^{63}$ A respeito do tema, CAMINO, Carmen. Direito Individual do Trabalho. 4. ed. Porto Alegre: Síntese, 2004.

${ }^{64}$ POCAR, La protection, op. cit., p. 365-366.

${ }^{65}$ Por todos os autores, MARQUES, Cláudia Lima. La propuesta "Buenos Aires". El más reciente avance en el marco de la CIDIP VII de protección de los consumidores. In: JAFFÉ, Angelina et al. (Coord.). Derecho y democracia III. Caracas: UNIMET, 2011. p. 123-160.

${ }^{66}$ JAYME, Erik, Métodos para la concretización del orden público en el derecho internacional privado. Trad. Eugenio Hernández Bretón. Revista de la Facultad de Ciencias Jurídicas y Políticas, n. 82, Universidad Central de Venezuela, Caracas, p. 217-270, 1991. p. 263.
} 
O direito europeu apresenta muitas normas dessa espécie. A título de exemplo, a chamada conexão mais estreita, norma presente no Regulamento Roma I, é, por si só, muito amplo e passível de diversas concretizações. Essas características podem dificultar a adaptação às necessidades de certeza e previsibilidade das relações privadas internacionais. Outra regra de conexão de caráter aberto é a da prestação característica. Essa solução impôs-se em razão da sua simplicidade e de motivos socioeconômicos. Na economia monetária, uma das prestações contratuais consiste no pagamento de uma determinada quantia em dinheiro, que em nada se distingue de outras prestações monetárias similares cumpridas em outros contratos, ainda que sejam de tipo diferente ${ }^{67}$.

Destaca-se que tais conexões abertas são também denominadas de cláusulas escapatórias ou de exceção ${ }^{68}$. Funcionam para corrigir eventuais falhas dos resultados práticos. Assim, deve ser salientado o caráter excepcional de tal solução, revelando a existência de conexões muito fracas com o ordenamento jurídico designado pela norma de conflito clássica. Dessa forma, a atuação da cláusula de exceção somente ocorre ao verificar-se, em concreto, as circunstâncias da causa, o que implica ao intérprete considerar todas as particularidades de cada caso ${ }^{69}$.

${ }_{67}$ Novamente destaca-se uma decisão da Corte Federal Suíça, datada de 10 de junho de 1952, R. 1953.390, na qual foi estabelecida como lei aplicável ao contrato aquela do local de execução da prestação característica da obrigação, a fim de solucionar a diversidade de leis passíveis de aplicação, em virtude do lex loci executionis (BATIFFOL, Traité, op. cit., p. 638-639).

${ }^{68}$ JAYME, Erik, Identité culturalle et intégration : le droit international privé postmoderne. Cours général de droit international privé. Recueil des Cours de l'Académie de Droit International de la Haye, 1995, t. 251. The Hague/Boston/London: Martinus Nijhoff Publishers, 1996. p. 44-47.

${ }^{69}$ Nesse sentido, a discussão da doutrina europeia acerca da prevalência das cláusulas abertas sobre as normas imperativas e vice-versa, trazida por Cláudia Lima Marques (MARQUES, A insuficiente, op. cit., p. 184-185). 
Com relação ao desenvolvimento das cláusulas de conexão abertas nos países de tradição Common Law, deve-se referir que os tribunais ingleses, a partir do século XIX, e em decorrência do desenvolvimento do comércio internacional, passaram a permitir a utilização do princípio da autonomia da vontade na escolha da lei aplicável. Então, passaram a desenvolver um princípio que ficou conhecido como Proper Law, no sentido de que, na ausência de definição da vontade das partes para indicar a lei aplicável, deveria o juiz presumi-la. Para a doutrina inglesa, as partes contratavam sempre com uma lei em mente, cabendo aos tribunais, diante do caso concreto, descobri-la ${ }^{70}$. Nesse sentido, valem os questionamentos trazidos por Vischer ${ }^{71}$, os quais denotam exatamente o conflito que passou a se colocar no âmbito do DIPr dos contratos. Deve o contrato ser localizado como um todo e, assim, questionar-se qual lei (ou qual Estado) governa esse contrato? Ou deve-se questionar apenas qual a lei mais relevante, ou mais apropriada para reger o contrato?

Nesse contexto, ganha importância o elemento de conexão favor empregado. Vale apresentar a contribuição de Haroldo Valladão $^{72}$ quanto à aplicação da lei mais favorável. Refere o

\footnotetext{
${ }^{70}$ ARAÚJO, Contratos, op. cit., p. 64-65.

71 VISCHER, Frank Benedict. The antagonism between legal security and the search for justice in the field of contracts. Recueil des Cours de l'Academie de Droit International de la Haye, Hague, v. 142, p. 339-396, 1975. p. 16.

72 VALLADÃO, Haroldo. O princípio da lei mais favorável no direito internacional privado. In: ORGANIZAÇÃO DOS ESTADOS AMERICANOS. Curso de derecho internacional. Washington, 1981. p. 523. Destaca-se que o autor incluiu tal princípio em sua proposta de lei sobre a matéria, na década de 1960, incluindo-o no "Capítulo III, Disposições de DIPr". Interessante também destacar que o autor, na página 524, defende ter o princípio origem muito remota, já sendo referido na obra de Hugo Grotius. Nas Américas, refere que Teixeira de Freitas já o mencionava, o que deu origem ao art. 14 Código Civil Argentino: "Las leyes extranjeras no serán aplicables: 1) Cuando su aplicación se oponga al derecho público o criminal de la República, a la religión
} 
autor brasileiro que o princípio da lei mais favorável apresenta-se muito antigo e restrito no âmbito do DIPr, mas tem tomado vulto e amplitude na atualidade. Constitui um elemento de conexão bastante original, pois parte de uma comparação substancial entre a lei do país onde se levantar a questão, habitualmente a lei do foro; a lei nacional e a lei, ou leis estrangeiras que a impregnaram. E conclui-se pela aplicação da lei que for mais favorável, seja à validade do ato, ou ao interesse do menor ou incapaz, ao interesse do filho, ao do pupilo, ao do alimentado, ao do devedor, ao do herdeiro legítimo etc. Dessa forma, constitui uma solução amplamente aceita, por exemplo, no Direito Internacional Privado de Família ${ }^{73}$.

$\mathrm{O}$ autor italiano Fausto Pocar $^{74}$ chama a atenção para o seguinte fato: para que haja uma efetiva proteção do sujeito mais fraco da relação contratual, deve-se ter presente que muitas vezes uma regra de conexão apenas não se apresenta como única solução. Deve haver uma aplicação conjunta. Deve-se realizar, ao lado da análise do conjunto do método conflitual disponível, um exame material do conteúdo do direito designado pela norma de conflito. Daí a importância do favor empregado.

Nesse sentido, Alfred Overbeck ${ }^{75}$ refere que as soluções inspiradas em preocupações materiais são de três ordens: as regras de conflito podem ser formuladas de maneira a aplicar a: 1. lei mais familiar à pessoa que querem proteger; 2. a lei

del Estado, a la tolerancia de cultos, o a la moral y buenas costumbres; 2) Cuando su aplicación fuere incompatible con el espíritu de la legislación de este Código; 3) Cuando fueren de mero privilegio; 4) Cuando las leyes de este Código, en colisión con las leyes extranjeras, fuesen más favorables a la validez de los actos." (grifo nosso).

${ }^{73}$ VALLADÃO, O princípio, op. cit., p. 522-526.

${ }^{74}$ POCAR, La protection, op. cit., p. 360.

${ }^{75}$ OVERBECK, Les questions, op. cit., p. 75. 
que determine o resultado almejado, como a manutenção de um contrato, o estabelecimento de uma filiação ou a validade de um testamento, ou, enfim; 3. pode deixar uma maior amplitude para as próprias partes envolvidas determinarem elas mesmas a lei aplicável $^{76}$.

No direito brasileiro, podemos identificar na própria Constituição Federal um exemplo de norma prevendo a utilização dessa técnica. $\mathrm{O}$ art. 5o, XXXI, da Constituição Federal estabelece que "A sucessão de bens de estrangeiros situados no País será regulada pela lei brasileira em benefício do cônjuge ou dos filhos brasileiros, sempre que não thes seja mais favorável a lei pessoal do de cujus." Esse dispositivo, além de estabelecer o direito fundamental dos brasileiros, a fim de regular a sucessão com elementos de estraneidade, traz cláusulas abertas e subsidiárias.

Nesse dispositivo constitucional, aparece o princípio da norma mais favorável que, embora bastante antigo, não teve aplicação marcante na legislação jusprivatista. Os elementos de conexão da Lei de Introdução às Normas de Direito Privado ainda se mostram excessivamente rígidos. Assim, embora a regra seja a aplicação da lei brasileira para

\footnotetext{
${ }^{76}$ Ancel e Lequette (ANCEL, Bertrand; LEQUETTE, Yves. Les grands arrêts de la jurisprudence française de droit international prvié. 4 ed. Paris: Dalloz, 2001. p. 195) apresentam uma outra classificação tripartite sobre normas conflituais de caráter material: 1. a partir da opção do legislador, a exemplo do art. 311-16, al. 2 do Código Civil Francês ("la légitimation par autorité de justice est régie, au choix du requérant, soit par la loi personnelle de celui-ci, soit par la loi personnelle de l'enfant"); 2. a partir da atuação do magistrado perante uma pluralidade de leis, a exemplo do art. 5ำ do Regulamento Roma I já referido; 3. a partir de uma regra que leva em consideração outras regras, a exemplo do art. 311-17 do Código Civil Francês ("la reconnaissance volontaire de paternité ou de maternité est valable si elle a été faite em conformité, soit de la loi personnelle de son auteur, soit de la loi personnelle de l'enfant"). Assim, os resultados materiais buscados pela regra - a validade e o reconhecimento da paternidade ou maternidade - são obtidas se uma das duas leis os consagrar.
} 
regular a sucessão dos bens situados no Brasil, considerando o elemento clássico da Lei de Introdução, o dispositivo abre a possibilidade de aplicação da lei estrangeira, caso seja aquela que mais beneficie os herdeiros.

Conforme, então, já ressaltado, enquanto a regra de conflito tradicional apresenta-se indiferentemente ao conteúdo das leis em análise, há numerosas regras de DIPr que têm se afastado desse princípio. E esse distanciamento resulta da estrutura desse novo tipo de regras, nas quais prevalecem as conexões alternativas, subsidiárias ou cumulativas ${ }^{77}$. Nos dois primeiros casos, a regra tende a favorecer um resultado. Constata-se que elas são de natureza mista, compostas por um elemento de conexão e por um elemento substancial. Por isso, também são denominadas regras de "conflito com coloração material" ${ }^{78}$.

77 Vale referir uma classificação das normas de DIPr, elaborada por Werner Gosdschmidt (GOLDSCHMIDT, Sistema, op. cit., p. 189-192), a partir do ponto de conexão que apresentam. Podem ter conexão não-cumulativa simples, tais como aquelas que aplicam uma lei a um determinado aspecto, tais como a conexão sobre propriedade ou posse, que determina a lei do lugar onde está situado o imóvel, por exemplo (art. 8o da Lei de Introdução.). A conexão pode ser não-cumulativa condicional, subdividida em subsidiária ou condicional. A não-cumulativa condicional subsidiária, ocorre quando a norma indireta apresenta apenas um ponto de contato, mas refere-se também a um segundo (ou subsequente) caso a conexão não se perfectibilize. Já na conexão não-cumulativa condicional alternativa a norma indireta oferece vários pontos de contato, dentre os quais a eleição vai decorrer da livre vontade das partes (autonomia da vontade) ou em virtude de um fato determinado pela regra geral a favor do direito mais favorável em determinado aspecto (favor legis). Podem, por outro lado, as normas terem conexões cumulativas, quando a uma só questão, aplicam-se vários lei. Subdividem-se em iguais e desiguais. As cumulativas iguais ocorrem quando uma mesma questão é submetida a diferentes leis, de forma independente uma da outra; assim, apenas uma coincidência entre as leis aplicáveis permite chegar a uma solução positiva. (art. 2 da Convenção de Haia sobre Separação e Divórcio). Já as cumulativas desiguais consistem em aplicar a uma questão apenas um direito que, inobstante, está submetido à comparação de um outro direito, que serve de guia. Por exemplo, o autor cita o artigo $2^{\circ}$ da lei de 14 de julho de 1891, na qual um co-herdeiro francês deve herdar no estrangeiro, pelo menos, o que herdaria se o direito francês fosse aplicável.

78 AUDIT, Le droit, op. cit., p. 427. 
Enfim, as pedras angulares do direito interno passaram a ter uma influência sobre a concepção das regras de DIPr, ampliando ao interior desse ramo uma ideia de proteção que se encontrava no seio do direito material.

Portanto, a regra é diretamente substancial quando visa à proteção de uma categoria de pessoas reputadas em situação de vulnerabilidade. Assim, por exemplo, é o artigo 311-1879 do Código Civil Francês sobre alimentos, sendo que a lei que rege a obrigação de prestá-los pode ser tanto a da residência do alimentando, como a da residência do devedor, à escolha do primeiro.

\subsection{Favor Empregado}

No final da década de 1970, Gilda Russomano já recomendava o uso, sempre que possível e quando necessário, do princípio da lei mais favorável ao trabalhador, por corresponder ao espírito do direito do Trabalho ${ }^{80}$. Em termos legislativos, no âmbito da proteção internacional do empregado, mesmo antes da Constituição de 1988, a norma mais favorável ao empregado fez-se presente no art. $3^{\circ}$, II, da Lei $\mathrm{n}^{\circ}$ 7.064/82 ${ }^{81}$. Essa lei, juntamente com o Decreto no 89.339/84, regula a situação dos trabalhadores contratados no Brasil,

\footnotetext{
79 "Article 311-18 L'action à fins de subsides est régie, au choix de l'enfant, soit par la loi de sa résidence habituelle, soi par la loi de la résidence habituelle du débiteur."

${ }^{80}$ RUSSOMANO, Direito, op. cit., p. 109.

81 "Art. 3․ A empresa responsável pelo contrato de trabalho do empregado transferido assegurar-lhe-á, independentemente da observância da legislação do local da execução dos serviços: [...] II - a aplicação da legislação brasileira de proteção ao trabalho, naquilo que não for incompatível com o disposto nesta Lei, quando mais favorável do que a legislação territorial, no conjunto de normas e em relação a cada matéria."
} 
ou transferidos por empresas prestadoras de serviços de engenharia. Aos demais empregados, prevalecia a regra da Súmula no 207 do TST ${ }^{82}$, ou seja, a lex loci executionis, ou a lei do lugar da execução do contrato de trabalho.

Como a regra estava restrita aos trabalhadores do ramo de engenharia, em 2009, foi editada a Lei no ${ }^{1} 11.962 / 09$, estendendo a todos os empregados contratados no país, ou transferidos para o exterior, a regulamentação da Lei $\mathrm{n}^{\mathrm{o}}$ 7.064/82. Em realidade, positivou-se o que a jurisprudência do TST já vinha estabelecendo até então ${ }^{83}$.

Nesse contexto, possuindo o TST uma base legislativa mais ampla, pôde, enfim, proceder ao cancelamento da Súmula no 207 do TST, por meio da Res. no 181 de 16 de abril de 2012. Na mesma decisão que originou o cancelamento, decidiu alargar as hipóteses de aplicação das regras da Lei n⿳⺈ 7.064/1982.

Portanto, prevalece no TST o seguinte regramento quanto ao trabalhador transferido para o exterior: 1. aplica-se a regra da lex loci executionis para os casos ocorridos antes do advento da Lei $\mathrm{n}^{\mathrm{o}}$ 11.962/09, quando o trabalhador foi contratado no Brasil para trabalhar diretamente no exterior, sem pertencer ao segmento empresarial referido no texto primitivo da Lei $n^{\text {o } 7.064 / 82, ~ n e m ~ e x e c u t a r ~ q u a l q u e r ~ p a r t e ~}$ do seu contrato no país; 2 . aplica-se a Lei no 7.064/82 para os trabalhadores contratados no Brasil e transferidos, ou

82 FRANCO FILHO, Contratos, op. cit., p. 40-41.

${ }^{83}$ RR - 129933/2004-900-01-00.2, Rel. Min. Alberto Luiz Bresciani de Fontan Pereira, julgado em 20 de maio de 2009, 3. ․ Turma; ROAR - 55560/1999-000-01-00.0, Rel. Min. Kátia Magalhães Arruda, julgado em 02 de outubro de 2007, Subseção II Especializada em Dissídios Individuais; RR - 376707/1997.1, Rel. Min. Maria Cristina Irigoyen Peduzzi, julgado em 12 de dezembro de 2001, 3. ํㅜ Turma. 
contratados para trabalhar diretamente no exterior no ramo da engenharia; 3. aplica-se a proteção normativa mínima da ordem jurídica trabalhista brasileira ao trabalhador contratado no país, que aqui tenha laborado para seu empregador, sofrendo subsequente remoção para país estrangeiro. Essa última classe de trabalhadores terá seu contrato de trabalho igualmente regido pelo critério da norma jurídica mais favorável brasileira ou do país estrangeiro, respeitado o conjunto de normas em relação a cada matéria ${ }^{84} ; 4$. após o advento da Lei $n^{\circ}$ 11.962/09, aplica-se a Lei $n^{-0} 7.064 / 82$, para o trabalhador contratado para laborar diretamente no exterior, independentemente do segmento empresarial a que pertença seu empregador.

Verifica-se, assim, que, tendo o trabalhador contato com a lex fori, esse deve ser o seu patamar mínimo de proteção, independentemente do momento em que contratado e do segmento empresarial a que pertença. Ao mesmo tempo em que se reduziram as hipóteses de aplicação da lex loci executionis, regra conflitual clássica, abrangeu-se a possibilidade de utilização da favor empregado, tendo como critério inicial de comparação a lex fori.

A solução do TST não propõe um simples retorno à legislação nacional, possibilitando a aplicação de outras normas estrangeiras, desde que mais favoráveis ao empregado.

${ }^{84}$ RR - 134700-43.2003.5.02.0060, Rel. Min. Mauricio Godinho Delgado, julgado em 03 de outubro de 2012, 3ª Turma. 


\section{Considerações Finais}

A crescente internacionalização das relações privadas tem trazido mudanças significativas nas relações de trabalho. Diante das particularidades do contrato de trabalho, com a figura de uma parte intrinsecamente mais vulnerável, as mudanças almejadas pela doutrina do DIPr no âmbito das relações contratuais como um todo têm sido experimentadas no âmbito da jurisprudência trabalhista. Nesse ramo trabalhista, a presença de elementos de conexão abertos e alternativos já vem ocorrendo desde a década de 1980, quando nem mesmo a Constituição de 1988, com sua tendência de proteção dos direitos fundamentais e de abertura para as relações internacionais, havia sido editada.

A evolução da jurisprudência do TST no sentido de uma materialização do DIPr deu-se por ser mais familiar ao âmbito desta Justiça Especializada no princípio da norma mais favorável. Independentemente disso, o cancelamento da Súmula no 207 do TST indica a percepção da insuficiência do método conflitual clássico na proteção da parte mais fraca.

Entretanto, a regra de conexão da lei do lugar da execução do contrato de trabalho ou lex loci laboris não deve desaparecer. Conforme preconiza a Lei $\mathrm{n}^{\mathrm{o}}$ 7.064/82, pode servir de instrumento alternativo para fixar a lei mais favorável ao empregado. Da mesma forma, o método conflitual clássico não deve ser abandonado. Suas soluções foram construídas ao longo dos séculos, permitindo uma apurada localização do ordenamento jurídico aplicável quando as situações encontram-se conectadas a mais de um Estado. Além disso, permite a harmonização entre os diferentes ordenamentos. 
Por outro lado, o resultado da lei indicada aplicável pela norma clássica não pode suprimir os direitos humanos fundamentais. Nesse contexto, a jurisprudência do TST demonstrou que o DIPr brasileiro já não é apenas de índole lógico-formal, mas capaz de assumir uma coloração material.

\section{Referências}

ANCEL, Bertrand; LEQUETTE, Yves. Les grands arrêts de la jurisprudence française de droit international privé. 4. ed. Paris: Dalloz, 2001.

ARAÚJO, Nádia de. Contratos internacionais: autonomia da vontade, Mercosul e convenções internacionais. 3. ed. Rio de Janeiro: Renovar, 2004.

AUDIT, Bernard. Le droit international privé a fin du XXe siècle: progrès ou recul. Revue International de Droit Comparé, n. 2, p. 421-448, avril/juin 1998.

BATALHA, Wilson de Souza Campos. Tratado elementar de direito internacional privado: parte geral. São Paulo: Revista dos Tribunais, 1961.

BATIFFOL, Henri. Traité élémentaire de droit international privé. 2. ed. Paris: LGDJ, 1955.

BEVILÁQUA, Clóvis. Princípios elementares de direito internacional privado. Campinas: RED, 2002.

BOGGIANO, Antonio. The contribution of the Hague conference to the development of private international law in Latin America: universality and genus loci. Recueil des Cours de l'Academie de Droit International de la Haye, Hague, n. 233, p. 103-266, 1993.

CAMINO, Carmen. Direito individual do trabalho. 4. ed. Porto Alegre: Síntese, 2004.

CASTRO, Amílcar. Direito internacional privado. 5. ed. Rio de Janeiro: Forense, 1997.

CHAPARRO, Verônica Zárate. O Estrangeiro à Luz do Direito Internacional e do Direito Brasileiro: Breves Considerações. In: DEL'OLMO, Florisbal de Souza (Coord.). Curso de Direito Internacional 
A Materialização do Direito Internacional Privado Brasileiro...

Contemporâneo: estudos em homenagem ao professor doutor Luís Ivani Amorim de Araújo pelo seu 80ㅜ aniversário. Rio de Janeiro: Forense, 2003.

DOLINGER, Jacob et al. O DIP no Brasil no século XXI. Revista Mexicana de Derecho Internacional Privado, número especial, p. 79-95, 2000.

. Direito internacional privado: parte geral. 7. ed. Rio de Janeiro: Renovar, 2003.

DROZ, Georges A. L. Regards sur le droit international privé comparé. Recueil des Cours de l'Académie de Droit International de La Haye, Hague, v. 4, n. 229, p. 13-423, 1991.

ELHOUEISS, Jean-Luc. L'élément d'extranéité préalable en droit international privé. Journal du Droit International, n. 1, p. 39-85, janv./mars 2003.

. Retour sur la qualification lege causae en droit international privé. Journal de Droit International, n. 2, p. 281-313, avril/juin 2005.

FERNÁNDEZ ARROYO, Diego P. El derecho internacional privado en el inicio del siglo XXI. In: MARQUES, Cláudia Lima; ARAÚJO, Nádia de (Org.). O novo direito internacional: estudos em homenagem a Erik Jayme. Rio de Janeiro: Renovar, 2005.

. Prefácio. In: JAEGER JUNIOR, Augusto. Europeização do Direito Internacional Privado - Caráter Universal da Lei Aplicável e outros Contrastes com o Ordenamento Jurídico Brasileiro. Curitiba: Juruá, 2012.

FRADERA, Véra Maria Jacob de. O direito dos contratos no século XXI: a construção de uma noção metanacional de contrato decorrente da globalização, da integração regional e sob influência da doutrina comparatista. In: DINIZ, Maria Helena; LISBOA, Roberto Senise. O direito civil no século XXI. São Paulo: Saraiva, 2003.

FRANCO FILHO, Georgenor de Sousa. Contratos Internacionais do Trabalho. Revista Síntese Trabalhista e Previdenciária, v. 23, n. 265, p. 30-43, jul. 2011.

GOLDSCHMIDT, Werner. Sistema y filosofía del derecho internacional privado. Barcelona: Bosch, 1948.

JAEGER JUNIOR, Augusto. Europeização do Direito Internacional Privado - Caráter Universal da Lei Aplicável e outros Contrastes com o Ordenamento Jurídico Brasileiro. Curitiba: Juruá, 2012. 
JAYME, Erik. Identité culturalle et intégration: le droit international privé postmoderne. Cours général de droit international privé. Recueil des Cours de l'Académie de Droit International de la Haye, 1995, t. 251. Hague/Boston/London: Martinus Nijhoff Publishers, p. 9-268, 1996.

Métodos para la concretización del orden público en el derecho internacional privado. Tradução de Eugenio Hernández Bretón. Revista de la Facultad de Ciencias Jurídicas y Políticas, n. 82, Universidad Central de Venezuela, Caracas, p. 217-270, 1991.

LOUIS-LUCAS, Pierre. La distinction du fond et de la forme dans le règlement des conflits de lois. In: MAURY, Jacques (Org.). Mélanges offerts Jacques Maury. t. 1: Droit international privé et public. Paris: Dalloz, 1960. p. 175-205.

MARQUES, Cláudia Lima. A insuficiente proteção do consumidor nas Normas de Direito Internacional Privado - Da necessidade de uma Convenção Interamericana (CIDIP) sobre Lei Aplicável a Alguns Contratos Relações de Consumo. In: MARQUES, Cláudia Lima; ARAÚJO, Nádia de (Org.). O Novo Direito Internacional estudos em homenagem a Erik Jayme. Rio de Janeiro, São Paulo e Recife: Renovar, 2005.

. La propuesta "Buenos Aires". El más reciente avance en el marco de la CIDIP VII de protección de los consumidores. In: JAFFÉ, Angelina et al. (Coord.). Derecho y democracia III. Caracas: UNIMET, 2011. p. 123-160.

MARTINS, Sérgio Pinto. Origens e Fundamentos do Direito Internacional Privado e Relações com o Direito do Trabalho. Revista do Tribunal Regional do Trabalho da $8^{\underline{a}}$ Região. Belém, v. 30, n. 58, p. 107-127, jan./jun. 1997.

OLIVEIRA, Elsa Dias. A protecção dos consumidores nos contratos celebrados através da internet: contributo para uma análise numa perspectiva material e internacional privatista. Coimbra: Almedina, 2002.

OVERBECK, Alfred E. von. Les questions générales du droit international privé à la lumière des codifications récents. Recueil des Cours de l'Academie de Droit International de la Haye, Hague, v. 3, n. 176, p. 13-258, 1983.

PIOVESAN, Flávia. Direitos Humanos e Direito Constitucional Internacional. 5 ed. São Paulo: Max Limonad, 2002. 
A Materialização do Direito Internacional Privado Brasileiro...

ROCHA, Osíris. Contrato Internacional de Trabalho: conseqüências brasileiras. Revista LTr: Legislação do Trabalho, São Paulo, v. 58, n. 5, p. 530-533, maio 1994.

RUSSOMANO, Gilda Maciel Corrêa Meyer. Direito Internacional Privado do Trabalho. Rio de Janeiro: Forense, 1979.

. Os Conflitos Espaciais de Leis no Plano das Relações Trabalhistas. José Konfino: Rio de Janeiro, 1964.

SOUZA JÚNIOR, Lauro da Gama e. Os princípios do Unidroit relativos aos contratos comerciais internacionais e sua aplicação nos países do Mercosul. In: RODAS, João Grandino (Org.). Contratos internacionais. São Paulo: Revista dos Tribunais, 2002. p. 427-464.

SPIES, André Luis. Reflexões Trabalhistas acerca do Direito Internacional Privado. Um Pressuposto Científico para Futura Harmonização Legislativa no MERCOSUL. Revista de Jurisprudência Trabalhista do Rio Grande do Sul, ano XV, n. 172, Porto Alegre: HS Editora, p. 111-121, abr. 1998.

SÜSSEKIND, Arnaldo. Conflitos de Leis do Trabalho. Rio de Janeiro: 162 Freitas Bastos, 1979.

VALLADÃO, Haroldo. O princípio da lei mais favorável no direito internacional privado. In: ORGANIZAÇÃO DOS ESTADOS AMERICANOS. Curso de derecho internacional. Washington, 1981. p. 522-560.

VISCHER, Frank Benedict. The antagonism between legal security and the search for justice in the field of contracts. Recueil des Cours de l'Academie de Droit International de la Haye, Hague, v. 142, p. 339-396, 1975.

Submissão: $16 / 11 / 2012$ Aceito para Publicação: 27/08/2013 


\title{
Inovações do Código Civil Brasileiro de 2002 na Disciplina do Negócio Jurídico Simulado
}

\author{
Innovations on the Brazilian Civil Code of 2002 \\ Concerning the Normative Discipline of Simulated \\ Transactions
}

Angela Cristina Viero*

Resumo: $\mathrm{O}$ presente artigo tem por objetivo analisar a disciplina do Código Civil de 2002 no que se refere à simulação nos negócios jurídicos. O Código Civil atualmente em vigor inovou na regulamentação dos negócios jurídicos simulados em relação ao Código Civil revogado, fundamentalmente, quanto à causa da simulação, para que o fenômeno seja relevante para o Direito, bem como no que concerne à dimensão no mundo dos fatos jurídicos em que se situa o negócio jurídico simulado, com implicações nos efeitos da simulação entre aqueles que dele participam (partes) e aqueles que lhe são alheios (terceiros). Da sanção de nulidade prevista no art. 167, caput, decorre a possibilidade de arguição da simulação entre as partes entre si, circunstância que deve ser analisada com cautela em cada caso concreto, a fim de evitar que o escopo da simulação, quando fraudulenta, seja concretizado. Por outro lado, prevê o Código Civil de 2002 a inoponibilidade da simulação pelas partes em face dos terceiros de boa-fé, em homenagem à tutela da confiança, com a finalidade de preservação da segurança jurídica. Não obstante, quanto a este último aspecto, não há previsão de critérios que auxiliem na solução de eventuais conflitos entre diferentes categorias de terceiros de boa-fé.

${ }^{*}$ Universidade Federal do Rio Grande do Sul. 
Palavras-chave: Negócio Jurídico Simulado. Código Civil Brasileiro de 2002. Causa da Simulação. Nulidade. Efeitos.

Abstract: This article aims to analyze the normative discipline of the simulated transactions on the Brazilian Civil Code of 2002. The Civil Code currently in force has innovated on the rules about simulated transactions in comparison to the revoked Civil Code, fundamentally in relation at the motive of the simulation to become relevant for the legal system, as well as concerning the dimension on the world of facts in which are situated the simulated transactions, involving the effects of the simulation among the participants on it (parties) and those who are out of it (third parties). From the nullity sanction settled by the art. 167, caput, arises the possibility to argue for the simulation of the parties among themselves, circumstance that must be analyzed prudently in each case, to avoid that the objective pursued with the simulation, when it is fraudulent, to be rendered concrete. By the other hand, the Civil Code of 2002 settles to the parties the impossibility of opposing the simulation against thirds parties in good faith, in honor to protect trust intending to preserve legal certainty. Nevertheless, as far as this last aspect is concerned, there are not forecasted criteria to support solutions for eventual conflicts between different categories of thirds parties in good faith.

Keywords: Simulated Transactions. Brazilian Civil Code of 2002. Motive of Simulation. Nullity. Effects.

\section{Introdução}

A simulação constitui instigante e complexo fenômeno jurídico, que, de há muito, suscita controvérsias doutrinárias referentes à sua elaboração dogmática e à sua regulamentação.

No Brasil, com o advento do Código Civil de 2002, a disciplina aplicável aos negócios jurídicos simulados sofreu relevantes alterações em relação ao Código Civil de 1916: no que concerne à licitude ou ilicitude da simulação, para que 
seja considerada fato relevante para o Direito; no atinente à dimensão no mundo dos fatos jurídicos em que se situa o negócio jurídico simulado e, consequentemente, aos efeitos da simulação entre aqueles que dele participam e aqueles que lhe são alheios (terceiros).

Em outros termos, as regras pertinentes à simulação, introduzidas pelo Código Civil de 2002, apresentam, basicamente, duas inovações: no tocante à irrelevância dos fins pretendidos pelas partes como fator determinante de aplicação das normas relativas ao tema; no que diz respeito aos efeitos do negócio jurídico simulado, inter partes, e em relação a terceiros.

Estes aspectos, bem como a análise crítica das consequências deles decorrentes, constituem, respectivamente, a primeira e a segunda parte do presente artigo.

\section{A (Ir)relevância dos Fins Pretendidos pelas Partes no Negócio Jurídico Simulado}

\subsection{Simulação Lícita e Simulação Ilícita: Noções Gerais}

Entende-se por causa simulandi o interesse que leva as partes a celebrar um negócio jurídico simulado. Trata-se do motivo que induz a dar aparência a um negócio que não existe, o porquê do engano, e, segundo a doutrina de Jorge Mosset Iturraspe ${ }^{1}$ :

Como en el orden del accionar humano y, más aún, en el mundo de los negocios jurídicos no es verosímil un actuar

1 ITURRASPE, Jorge Mosset. Contratos Simulados y Fraudulentos. Tomo I: Contratos Simulados. Buenos Aires: Rubinzal-Culzoni, 2001. p. 59-60. 
sin causa, sin motivo determinante, es decir la comisión de un acto que no responda a una finalidad predeterminada, puede concluirse afirmando que el engaño, que es de la esencia de toda simulación, obedece siempre a una causa.

Segundo o critério das causas ou dos motivos que movem as partes na realização de um negócio jurídico simulado, a simulação pode ser classificada como lícita ou ilícita.

A simulação lícita ou inocente é aquela que não tem por objetivo prejudicar terceiros ou fraudar a lei, ou que, objetivamente, não lese terceiros nem viole disposição legal. O motivo determinante vincula-se a um interesse justificado; há engano, mas não prejuízo.

A doutrina cita como exemplos de simulação lícita: alguém que pretende enganar um parente que muito pede dinheiro emprestado simula uma diminuição de patrimônio ${ }^{2}$; 166 alguém que quer enganar terceiros, por mera ostentação, dando a impressão de riqueza, simula a compra de um imóvel valioso; um pai que possui um vultoso patrimônio, com a finalidade de estimular seu filho ao trabalho ou ao estudo, finge a perda de grande parte dos seus bens, transferindo-os, simuladamente, a terceiros ${ }^{3}$.

A mais frequente, no entanto, é a simulação ilícita, nocente ou fraudulenta, aquela que tem por objetivo lesar direitos de terceiros ou burlar a lei.

São exemplos de simulação ilícita: os negócios jurídicos de alienação de bens realizados pelo devedor quando visem a aparentar, em face dos credores, diminuição do

2 ALBALADEJO, Manuel. Derecho Civil I: Introducción y Parte General. Barcelona: Libreria Bosch, 1970. p. 508.

3 JONES, César Coronel. La Simulación de los Actos Jurídicos. Bogotá: Editorial Nomos, 1989. p. 98. 
ativo; a compra e venda de bem imóvel por valor inferior ao real, para que o imposto incidente seja reduzido; o tutor que adquire bens do tutelado por interposta pessoa.

A propósito da causa simulandi, preleciona Nicola Distaso $^{4}$ que, se por um lado a simulação nem sempre é destinada à obtenção de um resultado fraudulento, não se podendo excluir que interesses dignos de uma certa consideração - tais como a necessidade de subtrair-se a solicitações importunas, um escopo de vaidade ou de rèclame, ou o interesse em conservar o crédito para manter certas aparências sociais - possam aconselhar a criação de uma aparência, sem que aqueles que a realizam queiram lesar terceiros, por outro lado, é inegável que o procedimento simulado importa sempre uma mise en scène destinada a enganar alguém, uma fraude nas relações privadas. Ocorre que o engano que emana do procedimento de criação da aparência não é tal, necessariamente, em relação à intenção a que os simulantes se propõem a obter através da sua realização. Sob este aspecto, é sempre exato o ensinamento da doutrina tradicional segundo a qual a intenção dos simulantes pode ser lícita ou fraudulenta, não se podendo excluir que as partes, não perseguindo uma finalidade ilícita, apenas produzam no mundo externo uma falsa aparência, a qual é uma constante própria do procedimento. Em suma, uma coisa é o engano que emana da ilusão, da mise en scène, da não realidade contida na forma imitada, da alteração da realidade; outra é o engano agravado pela intenção de fraudar terceiros ou de violar a lei, não essencial à descrição do fenômeno, mas quase sempre presente, ou melhor, apenas excepcionalmente ausente dos dados do próprio fenômeno.

4 DISTASO, Nicola. La simulazione dei Negozi Giuridici. Torino: UTET, 1960. p. 79-81. 


\subsection{A Disciplina do Código Civil Brasileiro de 2002: Causa da Simulação e Sanção de Nulidade}

Na disciplina do Código Civil de 1916, para que a simulação fosse considerada defeito do ato jurídico, exigia-se a intenção dos simulantes de prejudicar terceiros ou de violar disposição de lei (art. 1035). O ordenamento, portanto, reprovava tão somente os atos simulados com fins ilícitos.

A disciplina do instituto no Código Civil de 2002, entretanto, suprimiu o dispositivo contendo tal exigência, de modo que surge a indagação: para que a simulação seja considerada defeito, é necessário que tenha sido praticada com intuito de prejudicar terceiros ou de violar disposição legal? Qualquer simulação deve ser reprovada pelo Direito? A discussão acerca de tal questão não é nova.

Clóvis Beviláqua, ao comentar o art. 103 do Código Civil de 1916, afirmou "considerar perigosa, apesar de tradicional, a doutrina de que a simulação, que não prejudica terceiros nem frauda a lei, é innocente, e como tal permitida". Na opinião do citado jurista, "melhor seria condemnar a simulação em todos os casos".

Na mesma esteira de pensamento, Jean Carbonnier, renomado jurista francês, também no séc. XX, após estabelecer a diferença de tratamento no Código Civil francês,

5 O disposto no art. 103 do Código Civil de 1916 foi legado de Augusto Teixeira de Freitas, o qual havia previsto regra similar (Esboço, art. 523). Não constava no Projeto primitivo apresentado por Clóvis Beviláqua. Deveu-se à Comissão Revisora do Governo a inserção do dispositivo na seção dedicada à simulação.

6 BEVILÁQUA, Clóvis. Código Civil dos Estados Unidos do Brasil Comentado. Quaderni del Master in Sistema Giuridico Romanistico e Unificazione del Diritto: con particolare attenzione all'unificazione del diritto dei contratti in Europa e in America Latina, collana diretta da Sandro Schipani, vol. III/3, Roma, p. 168, 2005. 
entre o regime geral (e liberal) ${ }^{7}$ e o regime excepcional ${ }^{8}$, mais severo, da simulação, asseverou:

L'idée que le droit doit être indifférent à la simulation sous pretexte qu'il y a des simulations licites est contestable à la lumière des faits. Dans l'immense majorité des cas, la simulation sert à une fraude (au préjudice des créanciers, des héritiers, du fisc). Il ne serait peut-être pas d'un moralisme excessif d'ériger en principe l'interdiction de la simulation et, par une généralisation du système de l'a. 1099, al. 2, la nulitté aussi bien de la contre-lettre que de l'acte apparent. Sans se faire trop d'illusions, on peut penser que l'insécurité juridique qui en résulterait aurait un effet préventif. Au demeurant, le probléme n'est pas de savoir si l'on pourra jamais empêcher, en fait, la simulation, mais si le droit doit la reconnaître.

\section{$[\ldots]$}

On pourrait se demander, cependant, si la simulation, historiquement très proche de la fraude à la loi, ne serait pas mieux à sa place à côté des atteintes à l'ordre public (cf. le plan d'AUBRY et RAU, I, § 34-35). Ce renversement de présentation, il est vrai, supposerait un renversement de conception, et que l'on cessât de faire de la simulation licite le principe, de l'illicite l'exception.

Na Parte Geral, Livro III (Dos Fatos Jurídicos), Título I (Do Negócio Jurídico), Capítulo V (Da Invalidade do Negócio Jurídico), do Código Civil de 2002 vem disciplinada a simulação, apresentando relevantes alterações em relação ao Código anterior:

7 O regime geral funda-se em duas proposições: quando a simulação é indiferente ou quando a contradeclaração coexiste com o ato aparente. É indiferente a simulação se não produz consequências próprias; é neutra, não prejudica terceiros nem gera proveito às partes contratantes. A coexistência da contre-lettre e do ato aparente, opera-se, segundo o art. 1.321, em duas diferentes esferas de aplicação: uma no que concerne aos efeitos da contradeclaração entre as partes (eficácia), a outra no que diz respeito aos efeitos da contre-lettre em relação a terceiros (ineficácia).

8 O regime excepcional da simulação é mais rígido, estabelecendo a nulidade, seja somente da contradeclaração, seja da contra declaração e do ato aparente. 
Art. 167. É nulo o negócio jurídico simulado, mas subsistirá o que se dissimulou, se válido for na substância e na forma.

$\S 1^{\circ}$ Haverá simulação nos negócios jurídicos quando:

I-aparentarem conferir ou transmitir direitos a pessoas diversas daquelas às quais realmente se conferem, ou transmitem;

II - contiverem declaração, confissão, condição ou cláusula não verdadeira;

III - os instrumentos particulares forem antedatados, ou pós-datados.

$\S 2{ }^{\circ}$ Ressalvam-se os direitos de terceiros de boa-fé em face dos contraentes do negócio jurídico simulado.

Art. 168. As nulidades dos artigos antecedentes podem ser alegadas por qualquer interessado, ou pelo Ministério Público, quando lhe couber intervir.

Parágrafo único. As nulidades devem ser pronunciadas pelo juiz, quando conhecer do negócio jurídico ou dos seus efeitos e as encontrar provadas, não lhe sendo permitido supri-las, ainda que a requerimento das partes.

Art. 169. O negócio jurídico nulo não é suscetível de confirmação, nem convalesce pelo decurso do tempo.

Atualmente, no Direito Brasileiro, a simulação é causa de nulidade do negócio, consoante disposição expressa contida no caput do art. 167 que, aliás, conservou no parágrafo primeiro e seus incisos, o art. 102 e incisos do antigo Código.

Aplicada, então, a disciplina das nulidades, não mais subsiste vedação à alegação da simulação pelas partes entre si, como determinava o art. 104 do Código de 1916. Esta é a leitura autorizada pela combinação dos artigos 167, caput, e 168, os quais - em perfeita sintonia com o regime das nulidades do respectivo ordenamento - aludem a "qualquer interessado", sem excluir os contratantes ${ }^{9}$.

9 Nesta mesma senda, MATTIETTO, Leonardo. Negócio Jurídico Simulado (Notas ao art. 167 do Código Civil). Revista Jurídica, v. 349, ano 54, nov. 2006. p. 104. PINHEIRO, Maria de Lourdes I. A Simulação no Código Civil de 2002. Direito \& Justiça Revista da Faculdade de Direito da PUCRS, v. 26, ano 24, ago./dez. 2002. p. 133. 
Este é, dentro do tema da simulação, um dos pontos que mais poderia gerar polêmicas, não fosse a clareza da disposição legal.

A doutrina sustenta a aplicação indistinta dos dispositivos anteriormente citados, abrindo as portas para que a simulação, lícita ou ilícita, possa ser alegada entre as partes simulantes em litígio de um contra o outro.

O enunciado $294^{10}$, aprovado na IV Jornada de Direito Civil do Conselho da Justiça Federal, comprova a assertiva: "Sendo a simulação uma causa de nulidade do negócio jurídico, pode ser alegada por uma das partes contra a outra."

Embora ninguém negue o alcance das disposições legais sob comento, não estão elas isentas de críticas, como a que tece Marcos Bernardes de Mello ${ }^{11}$ :

Revogado o art. 104 do Código Civil de 1916, desapareceu, em face da regra do art. 168 do Código Civil de 2002, a proibição de os que praticaram a simulação nocente não na poderem alegar em litígio entre si ou com terceiros porque foi desconsiderada a prudente e anciã regra, que nos vem do direito romano de que nemo de improbitate sua consequitur actionem. Por isso qualquer um dos figurantes do negócio simulado pode argüir a simulação, inclusive entre si, salvo contra terceiro de boa-fé, porque este é imune aos efeitos da simulação (Código Civil, art. 167, § $2^{\circ}$ ).

Nesse sentido, advertimos para o risco de uma das partes em simulação fraudulenta, após ter obtido o escopo ilícito perseguido através da simulação, intentar ação contra a outra parte simulante pretendendo o retorno da situação jurídica ao status quo ante.

${ }^{10}$ Disponível em: <http://www.apriori.com.br/cgi/for/post10921.html>. Acesso em: 25 out. 2007.

${ }^{11}$ MELLO, Marcos Bernardes de. Teoria do fato jurídico: plano da validade. 7. ed. rev. e atual. São Paulo: Saraiva, 2006. p. 137. 
É intuitivo que outorgar uma faculdade tal ao simulador fraudulento, que se vê traído por seu próprio cúmplice simulador, representa atribuir um benefício àquele que pratica ato ilícito, enquanto a função da norma, ao contrário, deveria ser a de desestimular a utilização da simulação na prática de ilícitos, de forma a, como assevera Spota ${ }^{12}$ :

[...] mantener la inseguridad jurídica, em torno de los inmorales, con un fin preventivo, sea para que la sanción contra el torpe tenga la mayor probabilidad de aplicarse, sea para satisfacer el propósito de orden público que inspira a toda norma.

Para que fique clara a assertiva, basta que se pense na seguinte hipótese: um devedor, desejando, furta-se ao pagamento de seus credores, vende simuladamente seus bens a terceiro, para aparentar situação de insolvência. Transcorrido o prazo prescricional para exigibilidade dos créditos, o devedor (simulado alienante) pretende o retorno dos bens ao seu patrimônio e manifesta esta intenção ao outro simulante (adquirente fictício), o qual, agindo com deslealdade, nega-se a efetuar voluntariamente a transferência ("devolução") dos bens. A lei atualmente concede ação ao simulado alienante - que se beneficiou da simulação para prejudicar terceiros (credores) contra o adquirente fictício para reaver os bens que ele mesmo subtraiu do seu patrimônio. Por conseguinte, o devedor que prejudicou seus credores obtém então a realização completa do plano ilícito que teve em mira ao realizar o negócio simulado $^{13}$. Este, por certo, não pode ser o escopo da lei.

\footnotetext{
12 Apud ITURRASPE, 2001, p. 68.

${ }^{13}$ ITURRASPE, 2001, p. 67.
} 
Por isso é que, embora não se possa afastar a possibilidade de que alguém se arrependa de levar a cabo um negócio reprovado por lei, é imperioso que tal arrependimento só possa conduzir à conservação da situação preexistente à torpeza, nunca a completar a manobra enganosa e prejudicial ${ }^{14}$.

Ainda a propósito da sanção legal estabelecida ao negócio jurídico simulado, tratando-se de simulação absoluta o negócio é nulo e não produz nenhum efeito, a teor do disposto no art. 167, caput, primeira parte; por outro lado, o mesmo art. 167, caput, segunda parte, estabelece a validade do negócio dissimulado se preenchidos os requisitos de substância e forma. Isto significa que, reconhecida a nulidade do negócio simulado, eventualmente poderá subsistir o dissimulado, implicando convalidação deste negócio, consoante permissivo do art. 170 do mesmo Diploma Legal ${ }^{15}$.

Optou o legislador por omitir a disposição sobre a intenção das partes em violar a lei ou prejudicar terceiros, não distinguindo, portanto, simulação maliciosa e simulação inocente. Tratada a simulação como causa de nulidade, qualquer negócio simulado é destituído de efeitos (salvo a hipótese de convalidação do negócio dissimulado), não importando a causa da simulação ${ }^{16}$.

José Carlos Moreira Alves, membro da Comissão Elaboradora e Revisora do Projeto do Código Civil brasileiro

\footnotetext{
${ }_{14}$ Neste sentido, Llambías e Ordaz, apud ITURRASPE, 2001, p. 67.

15 A implicação da regra contida no art. 167, caput, quanto aos efeitos da simulação entre as partes, será examinada com maior profundidade no item 2.1.

16 "Toda a simulação, inclusive a inocente, é invalidante." Enunciado 152 aprovado na III Jornada de Direito Civil do Conselho da Justiça Federal. Disponível em: <http:// daleth.cjf.gov.br/revista/enunciados/IIIJornada.pdf>. Acesso em: 25 out. 2007.
} 
de 2002, manifestando-se quanto ao tema da simulação afirmou $^{17}$ :

Ao disciplinar a simulação, apartou-se o Projeto inteiramente do sistema observado pelo Código vigente. A simulação, seja a relativa, seja a absoluta, acarreta a nulidade do negócio simulado. Se relativa, subsistirá o negócio dissimulado, se válido for na substância e na forma. Não mais se distingue a simulação inocente da fraudulenta; ambas conduzem ao mesmo resultado: nulidade do negócio simulado, e subsistência do dissimulado, se for o caso. Essa, aliás, a conseqüência - segundo a melhor doutrina - que resulta do art. 103 do Código em vigor, que não considera defeito a simulação inocente. Enfim, o Projeto, ressalvando os direitos de terceiros de boa-fé em face dos contraentes do negócio jurídico simulado, admite, como decorrência mesma da nulidade, que a simulação possa ser invocada pelos simuladores em litígio de um contra o outro, ao contrário do que reza o art. 104 da Codificação atual. Também para o Código Civil português de 1967 o negócio simulado é nulo, subsistindo o negócio dissimulado se válido for na substância e na forma; a distinção entre simulação inocente ou fraudulenta - que se entrevê no art. $242^{\circ}$, n. 1 , in fine - não produz qualquer efeito prático, pois a conseqüência, em ambos os casos, é a mesma; e, não obstante os simuladores (ainda que a simulação seja fraudulenta) possam argüir entre si a nulidade do negócio simulado, esta argüição não pode ser feita, por quem simulou, contra terceiro de boa-fé, entendida esta como "ignorância da simulação ao tempo em que foram constituídos os respectivos direitos".

De relevância capital o comentário do citado jurista, sobretudo quando menciona a impossibilidade de arguição de nulidade do negócio simulado pelos simulantes contra terceiros de boa-fé, referindo-se à previsão do parágrafo segundo do art. $167^{18}$.

17 ALVES, José Carlos Moreira. A parte geral do projeto de Código Civil brasileiro (subsídios históricos para o novo Código Civil brasileiro). 2. ed. aum. São Paulo: Saraiva, 2003. p. 118-120.

${ }^{18}$ O parágrafo segundo do art. 167 será objeto de análise específica no item 2.2. 


\section{Efeitos da Simulação}

\subsection{Entre as Partes}

A sanção estabelecida pelo Código Civil de 2002 para o negócio jurídico simulado, como já se referiu, é a de nulidade; logo, decretada a invalidade do negócio, opera-se a sua desconstituição.

Quanto à eficácia ex tunc da sentença desconstitutiva do ato nulo, diverge a doutrina.

Pontes de Miranda ${ }^{19}$ afirma que a sentença que decreta a nulidade do ato jurídico não desconstitui a eficácia do ato em si, porque o nulo é, em si mesmo, ineficaz:

O anulável produz efeitos. Só os deixa de produzir quando transita em julgado a sentença constitutiva negativa. Então, apagam-se, como se não tivessem sido (eficácia ex tunc), os efeitos anteriores. Não se dá isso com a decretação do nulo: desconstitui-se o ato jurídico; não, a eficácia, porque não se desconstitui o que não se constituiu. Quando se diz que não se pode impugnar negócio jurídico nulo, ou ato jurídico stricto sensu nulo, porque não há eficácia a extinguir-se, ex tunc, está certo: impugnar é lutar contra efeitos. Mas nem toda a alegação contra o inválido é impugnação: não se impugna o nulo, porque se fez do conceito de impugnação conceito de luta contra o ser e os seus efeitos.

De outro lado, Marcos Bernardes de Melo $^{20}$, sustenta a eficácia retroativa da sentença que decreta a nulidade do ato jurídico:

${ }_{19}$ PONTES DE MIRANDA, Francisco Cavalcanti. Tratado de Direito Privado. 4. ed. t. IV. São Paulo: Revista dos Tribunais, 1983. p. 35-36.

${ }^{20}$ MELLO, Marcos Bernardes de. Teoria do fato jurídico: plano da eficácia, $1^{\mathrm{a}}$ parte. 3. ed. rev., São Paulo: Saraiva, 2007. p. 57. 
Diferentemente, tem-se que é ex tunc (= desde antes, desde a origem) a eficácia quando atua em relação ao passado, alcançando efeitos que o ato jurídico a que se refere haja irradiado, eliminando-os, excluindo-os do mundo jurídico, ou criando novos, retroativamente. Na eficácia ex tunc há sempre retroeficácia.

Dessa espécie são exemplos:

(i) As sentenças desconstitutivas (= constitutivas negativas, na terminologia de Pontes de Miranda), porque desconstituem o ato jurídico e os seus efeitos. Nos casos de decretação de nulidade e anulabilidade tem-se que a eficácia da desconstituição do ato jurídico é sempre ex tunc: (a) em geral, apenas desjuridicizante, no caso de nulidade, porque não há o que deseficacizar, pois sua eficácia ou (a.a) é apenas aparente, não havendo, portanto, efeitos a desfazer, ou (a.b) excepcionalmente, é putativa, e, nessa hipótese sua ínsita definitividade importa não poder ser desmanchada.

Não obstante a controvérsia em relação aos efeitos da decisão que decreta a invalidade do ato jurídico, a doutrina demonstra um ponto de convergência: a inaptidão do ato nulo de produzir efeitos.

Segundo reza o art. 167, caput, primeira parte, do Código Civil, o negócio simulado é sempre nulo, desprovido de aptidão para a irradiação de efeitos.

Tratando-se de simulação absoluta - aquela que se verifica quando os contraentes, na realidade, não querem celebrar negócio jurídico algum, e só aparentemente o realizam, como em uma venda simulada feita pelo devedor de um bem de sua propriedade em prejuízo dos credores - a consequência será a desconstituição do negócio jurídico, tão somente.

Porém, descortinado o véu da aparência enganosa (desconstituído o negócio jurídico simulado, nulo), pode ocorrer que as partes tenham, na realidade, celebrado 
negócio jurídico diverso daquele que fizeram aparentar, colocando em prática o que se denomina simulação relativa ${ }^{21}$. Nesse caso, a aplicação do mesmo art. 167, caput, segunda parte, permite a validade do negócio dissimulado se preenchidos os requisitos de substância e forma ${ }^{22}$. Assim, decretada a nulidade do negócio simulado, eventualmente poderá valer o negócio dissimulado, aquele que as partes realmente quiseram celebrar, se preenchidos os requisitos legais substanciais e formais. É o fenômeno que Pontes de Miranda denomina extraversão ${ }^{23}$.

Marcos Bernandes de Mello ${ }^{24}$, no entanto, chama a atenção para o caso de ser maliciosa a simulação: verificada a ilicitude, a nulidade do ato simulado estende-se ao ato dissimulado, sendo incabível a extraversão. Esta a razão pela qual não se pode desprezar a relevância da distinção entre simulação lícita e ilícita, verbis:

${ }^{21}$ Simulação relativa é aquela em que se quer celebrar um determinado negócio jurídico, mas, aparentemente, realiza-se outro diverso: seja quanto ao caráter (venda por preço vil, quando se quer, na verdade, realizar uma doação), aos sujeitos (venda feita a terceira pessoa, para que esta aliene a coisa à esposa do primeiro vendedor), ou ao conteúdo (objeto do ato ou contrato diverso do real); cláusulas não sinceras, por exemplo, o preço na compra e venda superior ou inferior ao efetivamente pactuado; e uso de datas falsas ou lugar da celebração do ato não correspondente à realidade. Nesta espécie de simulação realizam-se dois atos jurídicos: de um lado, o ato ostensivo, simulado, aparente, de outro, o ato oculto, real, dissimulado, que é o verdadeiro.

22 “Na simulação relativa, o aproveitamento do negócio jurídico dissimulado não decorre tão somente do afastamento do negócio jurídico dissimulado, mas do necessário preenchimento de todos os requisitos substanciais e formais de validade daquele." Enunciado 293 da IV Jornada de Direito Civil do Conselho da Justiça Federal. Disponível em: <http://www.apriori.com.br/cgi/for/post10921. html>. Acesso em: 25 out. 2007.

23 "Exsurgimento do ato dissimulado, como ato jurídico, no lugar do ato jurídico simulado." PONTES DE MIRANDA, 1983, p. 402.

${ }^{24}$ MELLO, 2006, p. 132. 
Quando há simulação nocente, o ato simulado é, em essência, um ato ilícito, de modo que a nulidade deve alcançar não apenas o ato simulado como também o dissimulado, que houver, sendo inadmissível a extraversão. Só no que respeita a terceiros de boa-fé será possível haver eficácia jurídica, mesmo havendo nocência (art. 167, § $2^{\circ}$ ). Em caso de inocência, porém, não só prevalecem os efeitos relativos a terceiros de boa-fé, como se poderá dar efetividade ao negócio jurídico dissimulado que houver, por meio da extraversão.

Como se vê, não há como desconsiderar-se a distinção entre simulação nocente e inocente.

Tal orientação merece alguns esclarecimentos. Desde os Glosadores ${ }^{25}$ a essência da simulação é representada pela expressão aliud agere, aliud simulare, significando a antítese, a contraposição, entre o comportamento de fato (realidade negocial) e o ato negocial (simulado), sancionada com a prevalência da rei veritas sobre a aparência simulada. Disso, porém, não resulta automaticamente a validade do negócio dissimulado; para que isso ocorra, é necessário proceder-se à verificação da existência ou não de eventuais vedações e impedimentos normativos que se tenham pretendido evitar através do comportamento simulatório.

Em obra sobre o tratamento científico do tema pelos mestres das glosas, Fulvio Mancuso, jurista italiano, discorrendo sobre a simulação relativa, afirma que $^{26}$ :

${ }^{25}$ Para mais informações acerca da simulação no período das glosas, ver MANCUSO, Fulvio. La Teorica della Simulazione nell'Esperienza dei Glossatori: Da Irnerio ad Accursio e da Graziano a Giovanni Teutonico. Bologna: Monduzzi, 2004.

${ }^{26}$ MANCUSO, 2004, p. 129. Tradução livre de: "Altrettanto priva di incertezze è l'idea della simulatio de contractu ad contractum; usando un linguaggio meno tecnico (simulatio de causa ad causam) ma certamente più diretto, Azzone chiarì che la simulazione relativa in senso proprio e pieno si ha allorchè il simulatume l'actum siano riconducibili a due ipotesi rappresentative di negozi affatto diversi. Le parti rappresentano, simulando, una compravendita e in realtà stipulano una donazione. Il caso rammentato da Azzone è quello di una donazione (vietata) 
Também destituída de incertezas é a idéia da simulatio de contractu ad contractum: usando uma linguagem menos técnica (simulatio de causa ad causam) mas certamente mais direta, Azo esclareceu que se tem a simulação relativa em sentido próprio e pleno uma vez que o simulatum e o actum conduzam a duas hipóteses representativas de negócios completamente diversos. As partes representam, simulando, uma compra e venda e na realidade estipulam uma doação. O caso recordado por Azo é de uma doação (vedada) entre cônjuges celebrada por trás de uma aparente compra e venda: à nulidade do simulatum corresponde, em dita hipótese, enquanto ilícita, também a nulidade do negócio realmente estipulado (doação). Diversamente, no caso de não ser impedida aos sujeitos a estipulação do negócio dissimulado, a nulidade da compra e venda simulada contrapõe-se à validade, e, pois, ao pleno desdobramento dos efeitos da doação.

Prossegue Mancuso ${ }^{27}$, analisando glosa de Acúrsio: "No caso da doação entre cônjuges, a simulação é instrumento de realização de um negócio ilícito. Por este motivo, nulo é o 'simulatum' (a aparente venda) mas nulo é, também, o 'actum' (a doação)."

Se o negócio jurídico simulado consiste em uma compra e venda, e este negócio foi celebrado com a finalidade de ocultar uma doação que a lei considere anulável (como a hipótese prevista no art. 550 do Código $\mathrm{Civil}^{28}$ ), esta doação

tra coniugi celata dietro una apparente compravendita: alla nullità del simulatum corrisponde, in detta ipotesi, in quanto illecita, anche la nullità del negozio in realtà stipulato. Diversamente, qualora ai soggetti non sia impedita la stipula del negozio dissimulato, alla nullità della simulata compravendita si contrappone la validità e dunque il pieno dispiegamento degli effetti della donazione."

${ }^{27}$ MANCUSO, 2004, p. 151. Tradução livre de: “Nel caso della donazione fra coniugi, la simulazione è strumento di realizzazione di un negozio illecito. Per questo motivo, nullo è il simulatum (l'apparente vendita) ma nullo è altresì, l'actum (la donazione)."

${ }^{28}$ Art. 550. A doação do cônjuge adúltero ao seu cúmplice pode ser anulada pelo outro cônjuge, ou por seus herdeiros necessários, até 2 (dois) anos depois de dissolvida a sociedade conjugal. 
permanecerá anulável, porque a invalidade em menor grau é ex lege. O mesmo ocorreria se o negócio dissimulado fosse, por força de lei, considerado nulo.

Nesse sentido, valemo-nos também dos ensinamentos de Pontes de Miranda ${ }^{29}$, muito úteis, ainda que professados sob a égide do Código anterior:

A extraversão ocorre ainda que o ato jurídico aparente, se entrasse no mundo jurídico, tivesse de ser tido por nulo, ou anulável; porque só se hão de exigir existência e validade ao ato jurídico dissimulado.

\section{$[\ldots]$}

Se o ato jurídico aparente foi por simulação relativa nocente, entrou no mundo jurídico o suporte fático. $\mathrm{O}$ ato jurídico é apenas anulável. Enquanto não se decreta a anulação, ele é, e pode ser que prescreva a ação de anulação: não há pensar-se em substituição dele pelo ato jurídico dissimulado. Após a decretação, nada fica do acordo reprovável de vontades. Nem havia, nem há qualquer possibilidade de extraversão.

O primeiro pressuposto para que o ato jurídico dissimulado se extraverta é que tenha havido o elemento volitivo suficiente para ele. O princípio de que a vontade precisa ser manifestada também aqui cabe, posto que possa ser tácita. Depois vêm os outros pressupostos.

\section{$[\ldots]$}

Se a simulação é relativa e inocente, única espécie em que os figurantes podem alegar simulação relativa, então, sim, a sentença estabelece o que realmente foi querido pelos figurantes em lugar do que foi simulado.

${ }^{29}$ PONTES DE MIRANDA, 1983, p. 402-403. 
Logo, para que o negócio jurídico dissimulado seja válido entre as partes, além de estar conforme ao ordenamento jurídico no que tange aos requisitos de substância e forma, é necessário que não tenha sido celebrado com intuito ilícito, ou seja, deve ser negócio jurídico oculto em simulação inocente.

Este também é o posicionamento da doutrina nacional contemporânea, apresentado na III Jornada de Direito Civil do Conselho da Justiça Federal, que culminou na aprovação do Enunciado $153^{30}$, segundo o qual: "Na simulação relativa, o negócio simulado (aparente) é nulo, mas o dissimulado será válido se não ofender a lei nem causar prejuízo a terceiros."

Portanto, em ambos os casos (simulação absoluta ou relativa), existe um negócio jurídico simulado. Este negócio simulado, aparente, enquanto tal, por si só não produz qualquer efeito inter partes. No caso da simulação relativa, se as partes na realidade quiseram celebrar um negócio diverso do simulado, o dissimulado será válido entre elas, desde que lícito e conforme as disposições legais a ele aplicáveis ${ }^{31}$.

\subsection{Perante Terceiros}

O parágrafo segundo do art. 167 prevê a ressalva dos direitos de terceiros de boa-fé em face dos contraentes do negócio jurídico simulado.

${ }^{30}$ Disponível em: <http://daleth.cjf.gov.br/revista/enunciados/IIIJornada.pdf $>$. Acesso em: 25 out. 2007.

${ }^{31}$ PETTI, Giovanni Battista. Commentario teorico-pratico al Codice Civile diretto da Vittorio de Martino: Libro IV - Delle obbligazioni: La simulazione e l'invalidità del contratto, art. 1414-1469. Novara: Edipen, 1984. p. 39-40. 
Esta é a expressão no Direito Pátrio do princípio da inoponibilidade da simulação aos terceiros de boa-fé32, o qual, na dicção de Francesco Ferrara ${ }^{33}$, é

[...] estabelecido a favor de terceiros, não contra eles. Donde se segue que, se os terceiros podem contestar a prova da simulação que lhes seja oposta e torná-la inoperante a seu respeito, tem também a faculdade de se servirem das contradeclarações feitas pelas partes, ou de prova de qualquer forma usem, para restabelecer a inexistência ou ocultação do negócio jurídico, afim de obter conseqüências em vantagem própria. Isto é, podem os terceiros renunciar aos benefícios da lei, pela qual em relação a eles é decisivo o contrato aparente, cujos efeitos não podem ser destruídos pela prova que os contratantes aduzem duma intenção contrária e deliberada.

Note-se que se trata de uma exceção à regra da nulidade do negócio simulado prevista no caput do mesmo art. 167. Por conseguinte tem-se que um negócio jurídico nulo, por expressa determinação legal, possa produzir seus efeitos em relação aos terceiros de boa-fé "em face dos contraentes do negócio jurídico simulado".

Tal perspectiva pode, prima facie, parecer equivocada à luz da teoria das nulidades, já que o nulo não produz efeitos, não passa do plano da validade para o plano da eficácia.

Contudo, se atentarmos para a circunstância de que excepcionalmente o nulo também pode produzir efeitos, veremos que a técnica do legislador do Código não abandonou o rigor científico para privilegiar a boa-fé e a tutela

32 Exemplos no Direito Comparado: Código Civil Italiano, art. 1415; Código Civil Austríaco, § 916 (2); Código Suíço das Obrigações, art. 16; Código Civil Paraguaio, arts. 308 e 309.

${ }^{33}$ FERRARA, Francesco. A Simulação dos Negócios Jurídicos. Tradução de A. Bossa. São Paulo: Saraiva, 1939. p. 360. 
da confiança. Ao contrário, adotou coerente solução, sancionando energicamente com a nulidade o negócio jurídico simulado, este vazio jurídico semeador de incertezas, e, ao mesmo tempo, protegendo aqueles que ficam à mercê da aparência enganosa e que vêm a ser os mais prejudicados: os terceiros de boa-fé.

Discorrendo sobre a possibilidade de o nulo, eventualmente, produzir efeitos, afirma Antônio Junqueira de Azevedo ${ }^{34}$ :

Às vezes, pode ocorrer que, por exceção, um negócio nulo produza efeitos jurídicos (são os chamados efeitos do nulo), embora nem sempre esses efeitos sejam os próprios, ou típicos, como acima definidos.

$[\ldots]$

Todavia, é inegável que os casos de efeitos do nulo são exceções no sistema de nulidades e como tais devem ser tratadas. Os efeitos do nulo não são, em sua maior parte, também como havíamos salientado, os efeitos próprios do ato (isto é, os efeitos manifestados como queridos), e, portanto, nesses casos, não se pode dizer que o negócio tenha passado para o plano da eficácia; todavia, ainda quando se trate de eficácia própria, tal e qual ocorre no casamento putativo e em algumas outras poucas hipóteses, tem-se, se pudermos expressar-nos assim, um "furo" na técnica de eliminação com que os negócios são tratados; é a exceção que confirma a regra, tanto mais que, depois de o negócio haver entrado no plano seguinte, o sistema corrige a falha, impedindo que o negócio continue a produzir efeitos (a entrada dos negócios nulos no plano da eficácia não é, pois, definitiva.

${ }^{34}$ AZEVEDO, Antônio Junqueira de. Negócio jurídico: existência, validade e eficácia. 4. ed. atual. de acordo com o novo Código Civil (Lei n 10.406, de 10-1-2002). São Paulo: Saraiva, 2002, p. 49-64. 


\subsubsection{Terceiros de Boa-fé}

A simulação não pode ser arguida pelos contraentes do negócio jurídico simulado contra os terceiros de boa-fé.

Na lição de Francesco Ferrara ${ }^{35}$, são terceiros alheios ao negócio jurídico simulado:

[...] aqueles que não figuraram de modo algum no contrato simulado, nem nêle foram representados, nem são sucessores universais das pessoas que intervieram no contrato simulado. É possível, no entanto, que os herdeiros assumam, excepcionalmente a qualidade de terceiros quando se trata de defender um direito próprio que a lei lhes concede, como os herdeiros legitimarios que impugnam qualquer acto do autor da herança que lese o seu direito.

Sob o conceito amplo de terceiros estão pois compreendidos os que derivam o seu direito das partes a título particular, os adquirentes, subadquirentes, concessionários dum direito real, etc. e os credores quirografários.

Mas não basta ser terceiro para gozar da proteção legal contida na norma do art. 167, parágrafo segundo; deve haver boa-fé, entendida como ignorância da simulação, consoante lição de Ferrara ${ }^{36}$ : "A segunda condição... é que os terceiros estejam de boa-fé, isto é que ignorem que o negócio em cuja seriedade se fiaram ao contratar ou do qual derivam os seus direitos, seja simulado."

A doutrina nacional comunga deste entendimento. Alberto Júnior Veloso ${ }^{37}$ professa: “Nunca é demais lembrar que a boa-fé do terceiro consiste em desconhecer a simulação, pois se dela tem conhecimento, não há como escapar da nulidade do negócio aparente, e, portanto, será alcançado pelos seus efeitos."

\footnotetext{
${ }^{35}$ FERRARA, 1939, p. 361.

36 FERRARA, 1939, p. 362.

37 VELOSO, Alberto Júnior. Simulação - Aspectos Gerais e diferenciados à luz do Código Civil de 2002. Curitiba: Juruá, 2004. p. 168.
} 
Os terceiros de boa-fé contam, portanto, com a tutela expressa e incondicional do parágrafo segundo do art. 167, podendo alegar contra as partes o caráter meramente aparente do negócio jurídico, que, no entanto, perante eles será considerado eficaz.

Por outro lado, se o terceiro tiver conhecimento da simulação, podem as partes opor-lhe a simulação, e contra ele produzirá efeitos o negócio oculto ou dissimulado (desde que preencha os requisitos de substância e forma, observadas as disposições legais a ele aplicáveis; caso contrário o negócio é igualmente nulo).

\subsubsection{Conflito entre Terceiros de Boa-fé}

Os juristas que se ocuparam da simulação advertiram para a possibilidade de ocorrer conflito entre duas diferentes categorias de terceiros de boa-fé.

Em face de um mesmo negócio jurídico simulado, pode haver, de um lado, o interesse em que prevaleça a verdade real (e, eventualmente, havendo, o negócio oculto, dissimulado), e, de outro, o interesse na validade e eficácia do negócio jurídico simulado.

A orientação da doutrina tende à eficácia do ato aparente. Esta solução seria a que está mais de acordo com o valor inspirador do princípio da inoponibilidade da simulação aos terceiros de boa-fé, qual seja, garantir segurança àqueles que confiam nos atos ostensivos ${ }^{38}$.

38 ALESSANDRI, Arturo; SOMARRIVA, Manuel; VODANOVIC, Antônio. Tratado de Derecho Civil: Partes Preliminar y General. t. II. Santiago: Editorial Jurídica de Chile, 1998. p. 365. 
Deve-se, no entanto, perquirir acerca da justiça desta solução nos diferentes casos concretos, levando-se em consideração as hipóteses mais comuns de terceiros, vítimas de negócios jurídicos simulados.

Alberto Júnior Veloso ${ }^{39}$, acrescentando colaborações pessoais à proposição de Beleza dos Santos, apresenta uma série de hipóteses de conflito entre terceiros de boa-fé, com diferentes soluções, a saber:

\subsubsection{Conflito entre Credores do Alienante Aparente e do Adquirente Fictício:}

Prevalece a nulidade do ato aparente, e, assim, a pretensão dos credores do fictício alienante. Sendo caso de 186 simulação absoluta, o negócio jurídico aparente será declarado nulo, e os bens serão considerados como integrantes do patrimônio do alienante aparente;

\subsubsection{Conflito entre Credores Comuns do Simulado Alienante e Sucessores a Título Singular - por Aquisição Translativa ou Constitutiva - do Adquirente Fictício:}

O ato aparente será considerado eficaz. Os credores do simulado alienante poderão, porém, rescindir o negócio aparente, como poderiam fazê-lo através de ação pauliana se fosse verdadeiro o negócio, nos casos autorizados por lei;

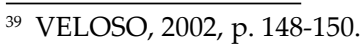




\subsubsection{Conflito entre Sucessores a Título Singular do Simulado Alienante e Credores Comuns do Adquirente Fictício:}

Não há justificativa para que os credores do adquirente fictício pretendam a permanência no patrimônio do seu devedor, de bens que são legitimamente exigidos por terceiros que adquiriram sobre eles direitos, e em face dos quais o devedor não poderia contrapor uma aquisição legítima. Trata-se de situação similar àquela em que se encontrariam os credores se o devedor fosse evicto de bens que estavam no seu patrimônio, mas que foram reivindicados por terceiros com direito a eles. Considera-se que tais bens estão indevidamente em poder do devedor, simulado adquirente;

\subsubsection{Conflito entre Sucessores a Título Singular do Alienante Simulado e Sucessores a Título Singular do Adquirente Fictício:}

\subsection{Conflito Relativo a Bens Móveis:}

A solução independe da data em que se realizaram os negócios jurídicos e deve favorecer o terceiro que está na posse da coisa, porque a propriedade da coisa móvel se transfere com a tradição (art. 1627 do Código Civil); 
2.2.2.4.2 Conflito Relativo a Bens Imóveis:

Deve prevalecer a alienação que for registrada em primeiro lugar, em harmonia com o disposto nos art. 1.245 do Código Civil e arts. 172 e seguintes da Lei 6.015 de 31 de dezembro de 1973. Não havendo registro de qualquer das aquisições, aplica-se a solução estabelecida em relação às coisas móveis, vale dizer, concede-se o direito ao terceiro que estiver exercendo a posse do imóvel;

\subsubsection{Conflito Relativo a Títulos de Crédito:}

Prevalece a cessão de crédito que for primeiro notificada ao devedor, ou de que primeiro for dado conhecimento ao devedor;

\subsubsection{Conflito entre Herdeiros Legitimários do Simulado Alienante e Subadquirentes de Boa-fé:}

Pode ocorrer que os herdeiros de um simulado alienante tenham interesse em ver declarada a nulidade de uma aparente alienação que importe redução das legítimas. Por outro lado, à pretensão dos herdeiros pode contrapor-se o interesse de um ulterior adquirente de boa-fé, a quem o adquirente fictício tenha alienado ditos bens e que sofreria grave prejuízo se lhe fosse oposta a nulidade do negócio simulado. Assim, prevalecem os direitos dos subadquirentes, devendo ser tratada a situação como se os bens tivessem saído do patrimônio do autor da herança pela realização de negócio válido e legítimo. 


\subsubsection{A Solução do Código Civil Italiano de 1942 e as "Recomendações" Doutrinárias na Argentina}

Em relação aos efeitos da simulação em face dos terceiros de boa-fé e ao conflito entre eles, o Código Civil Italiano de 1942 (Libro IV: Delle Obbligazioni, Capo X), estabeleceu o seguinte regramento:

Art. 1415 Effetti della simulazione rispetto ai terzi

La simulazione (164) non può essere opposta né dalle parti contraenti, né dagli aventi causa o dai creditori del simulato alienante, ai terzi che in buona fede (1147) hanno acquistato diritti dal titolare apparente, salvi gli effetti della trascrizione della domanda di simulazione (2652).

I terzi possono far valere la simulazione in confronto delle parti, quando essa pregiudica i loro diritti $(1372,1417)$.

Art. 1416 Rapporti con i creditori

La simulazione non può essere opposta dai contraenti ai creditori del titolare apparente che in buona fede hanno compiuto atti di esecuzione sui beni che furono oggetto del contratto simulato (2910 e seguenti).

I creditori del simulato alienante possono far valere la simulazione che pregiudica $i$ loro diritti, e, nel conflitto con i creditori chirografari del simulato acquirente, sono preferiti a questi, se il loro credito è anteriore (2704) all'atto simulato.

Nicola Distaso ${ }^{40}$ propõe uma distinção fundamental na análise dos vários casos de conflitos derivantes da simulação: entre terceiros que têm interesse na eficácia do negócio simulado e na ineficácia do acordo simulatório, porque as suas relações jurídicas derivam de vínculo com o adquirente simulado; e entre terceiros que seriam prejudicados se declarada a eficácia do negócio simulado, que, por conseguinte, têm interesse em que prevaleça o acordo simulatório, mediante a oposição total ou parcial de ineficácia do negócio

${ }^{40}$ DISTASO, 1960, p. 492. 
simulado, em virtude do prejuízo decorrente de um ato de disposição levado a efeito pelo simulado alienante.

Esclarece Distaso ${ }^{41}$, para dirimir tais conflitos, o Código Civil italiano segue três critérios diversos que se integram: (a) tutela da confiança (art. 1.415, alínea 1; e 1416, alínea 2), segundo a qual a simulação é inoponível a quem tenha, de boa-fé, tratado com o titular aparente considerando-o como titular efetivo; (b) irrelevância da aparência perante todos os interessados, sejam as partes (art. 1414), sejam terceiros (art. 1415, alínea 2; art. 1416, alínea 2, primeira parte), razão pela qual a ação de simulação pode ser intentada por qualquer interessado; (c) anterioridade do título (art. 1416, alínea 2) em função do que, entre vários credores, prefere-se aquele que confiou na situação precedente ao negócio simulado.

Consoante já salientou-se, o Código Civil brasileiro em vigor não contempla previsão normativa para os casos de conflitos entre terceiros de boa-fé.

Entendemos que a ausência de normas neste sentido dificulta a atividade jurisdicional, impondo ao magistrado o recurso à doutrina - que se socorre das regras e soluções aplicáveis a outros institutos envolvidos, em cada caso -, nem sempre unânime nas soluções adotadas, apresentando sérios riscos de decisões injustas e em sentidos opostos para casos idênticos. Ressalte-se que tampouco as Jornadas de Direito Civil promovidas pelo Conselho da Justiça Federal ocuparam-se da problemática envolvendo o conflito entre as diferentes categorias de terceiros de boa-fé.

${ }_{41}$ DISTASO, 1960, p. 492-493. 
Não pretendemos defender aqui, absolutamente, deva o legislador prever todas as possíveis hipóteses de conflito; posicionamo-nos, todavia, no sentido da utilidade da fixação de critérios substanciais de base para a sua resolução.

O Código Civil italiano, demonstrando maturidade na elaboração das regras sobre o tema da simulação e das questões práticas relevantes que suscita para o intérprete e aplicador do Direito, possui normas alicerçadas em critérios seguros e os mais justos - tanto quanto possível - orientados pelos princípios que inspiram todo o ordenamento jurídico e que são especialmente vinculados à matéria, princípios estes que se destinam a prover segurança jurídica.

Na Argentina, cujo Código Civil, a exemplo do brasileiro, não possui regras dirimentes de conflitos entre terceiros de boa-fé - e que muito se assemelha, no pertinente ao tema da simulação, à disciplina do Código Civil brasileiro revogado -, existem "recomendações" doutrinárias para a tutela da confiança, que, não obstante incompletas para o fim de solucionar a problemática aqui aludida, ao menos lança e consolida as diretrizes para a atividade interpretativo-criativa da jurisprudência, consoante noticia Jorge Mosset Iturraspe ${ }^{42}$ :

El tema de la confianza en una declaración es inseparable del de la seguridad jurídica y del respecto a la apariencia. En las $X$ Jornadas de Derecho Civil, celebradas en Corrientes, en 1985, la Comisión $\mathrm{N}^{\circ} 8$ se ocupo de los efectos jurídicos de la apariencia, y produjo las "recomendaciones" siguientes: " $1^{\circ}$ ) la protección de la apariencia constituye un principio de Derecho que se extrae de una interpretación integradora del ordenamiento jurídico, y deriva de la finalidad de cubrir las necesidades del tráfico, la seguridad dinámica y la buena fe. $2^{\circ}$ ) El principio puede ser extendido fuera de los casos establecidos siempre que se den los presupuestos

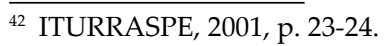


de aplicación. $3^{\circ}$ ) Son requisitos generales de la aplicación de la teoría de la apariencia: a) Una situación de hecho que, por su notoriedad sea objetivamente idónea para llevar a engaño a los terceros acerca del estado real de aquélla; b) frente a terceros, entre otros, que no hayan conocido o podido conocer la verdadera situación, obrando con la diligencia debida. $4^{\circ}$ ) En los actos de adquisición de derecho por terceros, se requiere que hayan sido efectuados a título oneroso, salvo norma expresa que establezca la protección del adquirente a título gratuito. $5^{\circ}$ ) Son efectos de la aplicación de la teoría de la apariencia: a) entre las partes del acto: entre otros, en ciertos casos la invalidez del acto queda saneada por la apariencia; $b$ ) frente a terceros: entre otros, produce los siguientes: I. Convalida la adquisición del derecho por el tercero de buena fé y a título oneroso que lo obtiene por un acto válido de quien, a su vez, lo tuvo a consecuencia de un acto inválido o ineficaz del adquirente. II. Legítima el ejercicio de un derecho por quien no es su titular (representación aparente). III. En algunos casos produce la inoponibilidad (por ej., contradocumento privado o público no anotado en la escritura matriz). c) Respecto del titular del derecho la pérdida o limitación de su derecho, lo faculta al ejercicio de las acciones resarcitorias que correspondieren.

Propomos, portanto, a reflexão sobre a conveniência de disponibilizar aos operadores do Direito Brasileiro, instrumentos mais efetivos para a solução de controvérsias que, indubitavelmente, poderão advir da interpretação do art. 167, parágrafo segundo, do Código Civil brasileiro de 2002, em casos envolvendo conflitos entre terceiros de boa-fé.

\section{Considerações Finais}

Da análise procedida nas páginas precedentes resulta evidente que as alterações promovidas pelo Código Civil de 2002 na disciplina relativa à simulação dos negócios jurídicos 
é assaz diversa da que lhe era instituída pelo Código Civil revogado. Hodiernamente qualquer que seja a simulação, não importando o motivo que lhe deu vida - intuito inocente ou malicioso das partes -, é reprovada pelo Direito e sancionada com a nulidade do negócio por meio do qual ela se realizou.

Relevante implicação decorrente da sanção de nulidade do negócio jurídico simulado diz respeito à legitimidade para a sua arguição: as partes, atualmente, estão autorizadas a alegar a simulação em litígio de uma contra a outra. Neste sentido, alertamos para a circunstância de que seria inimaginável que houvesse o legislador pretendido beneficiar os simuladores com intuito fraudulento, possibilitando a obtenção completa do resultado ilícito por eles perseguido. Assim, concluímos que o permissivo legal deve ser aplicado com cautelas, em cada caso concreto.

Não menos importante consequência da sanção de nulidade, resultante da previsão do art. 167, caput, primeira parte, é a desconstituição do negócio, independentemente de ser a simulação absoluta (aquela em que o único negócio querido pelas partes é o negócio simulado) ou relativa (em que as partes realizam um negócio simulado para ocultar o verdadeiro negócio jurídico havido entre elas). Tratando-se de simulação relativa, porém, o negócio oculto, dissimulado, poderá prevalecer, se for lícito e observar os requisitos substanciais e formais a ele aplicáveis (art. 167, caput, segunda parte).

Também os efeitos da simulação relativamente aos terceiros de boa-fé revestem-se de acentuado interesse prático. O parágrafo segundo do art. 167 coloca o ordenamento jurídico brasileiro na esteira de outras legislações e da doutrina mais autorizada. Tutelando a boa-fé e a confiança, estabelece 
a ressalva dos direitos dos terceiros em face dos contraentes do negócio simulado. Trata-se de uma exceção à teoria da nulidade: a produção de efeitos do negócio nulo. Assim, mesmo que os simulantes possam alegar entre si a simulação, não podem fazê-lo em relação aos terceiros de boa-fé.

Ainda quanto a este aspecto, mencionou-se a possibilidade de haver conflito entre diferentes categorias de terceiros de boa-fé, os quais podem ser divididos em dois grandes grupos: um deles integrado por aqueles que têm interesse na prevalência - na eficácia - do negócio jurídico simulado, porque adquiriram direitos com base neste; o outro, composto por aqueles que têm interesse na desconstituição do negócio simulado, na prevalência da rei veritas (que eventualmente pode ser a subsistência do negócio dissimulado), na medida em que a eficácia do negócio simulado prejudica seus direitos.

O Código Civil brasileiro de 2002 carece de normas e critérios específicos que auxiliem na solução de tal conflito, como o faz o Código Civil italiano de 1942, cujas disposições neste particular foram elaboradas com base nos princípios fundamentalmente envolvidos no tema; tampouco o faz a doutrina, sem que tenha que se socorrer de regras próprias de outros institutos, e, mesmo assim, suscitando controvérsias. Neste contexto, entendemos que normas claras, efetivas e específicas - se não exaustivas, que ao menos estabeleçam diretrizes concretas para a resolução desses conflitos -, além de úteis, mostram-se necessárias. 


\section{Referências}

ALBALADEJO, Manuel. Derecho Civil I: Introducción y Parte General. Barcelona: Libreria Bosch, 1970.

ALESSANDRI R. Arturo; SOMARRIVA U. Manuel; VODANOVIC H. Antonio. Tratado de Derecho Civil: Partes Preliminar y General. t. II. Santiago: Editorial Jurídica de Chile, 1998.

ALVES, José Carlos Moreira. A parte geral do projeto de Código Civil brasileiro (subsídios históricos para o novo Código Civil brasileiro). 2. ed. aum. São Paulo: Saraiva, 2003.

AZEVEDO, Antônio Junqueira de. Negócio jurídico: existência, validade e eficácia. 4. ed. atual. de acordo com o novo Código Civil (Lei n 10.406, de 10-1-2002). São Paulo: Saraiva, 2002.

BEVILÁQUA, Clóvis. Código Civil dos Estados Unidos do Brasil Comentado. Quaderni del Master in Sistema Giuridico Romanistico e Unificazione del Diritto: con particolare attenzione all'unificazione del diritto dei contratti in Europa e in America Latina, collana diretta da Sandro Schipani, vol. III/3, Roma: 2005.

CARBONNIER, Jean. Droit Civil: Les Biens et les Obligations. Tome II. $2^{a}$ Édition. Paris: Presses Universitaires de France, 1959.

DISTASO, Nicola. La simulazione dei Negozi Giuridici. Torino: UTET, 1960.

FERRARA, Francesco. A Simulação dos Negócios Jurídicos. Tradução de A. Bossa. São Paulo: Saraiva, 1939.

GAINO, Itamar. A Simulação dos Negócios Jurídicos. 2. ed. São Paulo: Saraiva, 2012.

ITURRASPE, Jorge Mosset. Contratos Simulados y Fraudulentos. Tomo I: Contratos Simulados. Buenos Aires: Rubinzal-Culzoni, 2001.

JONES, César Coronel. La Simulación de los Actos Jurídicos. Bogotá: Editorial Nomos, 1989.

MANCUSO, Fulvio. La Teorica della Simulazione nell'Esperienza dei Glossatori: Da Irnerio ad Accursio e da Graziano a Giovanni Teutonico. Bologna: Monduzzi, 2004. 
MATTIETTO, Leonardo. A simulação no novo Código Civil. Revista Trimestral de Direito Civil, ano 4, v. 13, p. 111-125, jan./mar. 2003.

- Negócio Jurídico Simulado (Notas ao art. 167 do Código Civil). Revista Jurídica, ano 54, v. 349, p. 93-107, nov. 2006.

MELLO, Marcos Bernardes de. Teoria do fato jurídico: plano da eficácia, $1^{\underline{a}}$ parte. 3. ed. rev. São Paulo: Saraiva, 2007.

. Teoria do fato jurídico: plano da validade. 7. ed. rev. e atual. São Paulo: Saraiva, 2006.

PETTI, Giovanni Battista. Commentario teorico-pratico al Codice Civile diretto da Vittorio de Martino: Libro IV - Delle obbligazioni: La simulazione e l'invalidità del contratto, art. 1414-1469. Novara: Edipen, 1984.

PINHEIRO, Maria de Lourdes I. A Simulação no Código Civil de 2002. Direito \& Justiça - Revista da Faculdade de Direito da PUCRS, ano 24, v. 26, p. 123-134, ago./dez. 2002.

PONTES DE MIRANDA, Francisco Cavalcanti. Tratado de Direito Privado. t. IV, 4. ed. São Paulo: Revista dos Tribunais, 1983.

TÔRRES, Heleno Taveira. Teoria da Simulação de Atos e Negócios Jurídicos. Revista dos Tribunais, ano 95, v. 849, p. 11-56, jul. 2006.

VELOSO, Alberto Júnior. Simulação: aspectos gerais e diferenciados à luz do Código Civil de 2002. Curitiba: Juruá, 2004.

Submissão: 10/06/2013

Aceito para Publicação: 14/08/2013 


\section{A Expansão dos Direitos \\ de Propriedade Industrial \\ na União Europeia}

\section{The Expansion of Industrial Property Rights in the European Union}

Marcelo Schultes*

Resumo: A principal questão deste estudo é que, no ambiente de integração econômica da União Europeia, para que se perfectibilize o mercado interno, faz-se necessário o tratamento integrado da propriedade industrial no território do tratado, que pode ser caracterizado como a centralização de procedimentos e alargamento da validade dos títulos de propriedade industrial no espaço da União Europeia. As necessidades econômicas do mercado interno no espaço de integração demandam trazer à competência da União matérias antes tratadas nacionalmente pelos estados membros, notadamente quando se fala em temas de direito privado. A propriedade industrial é um bom exemplo disso, e o legislador europeu está paulatinamente trazendo a regulação dessa matéria para dentro do ordenamento da União.

Palavras-chave: União Europeia. Propriedade Industrial. Direito Privado. Alargamento. Marcas. Patentes. Design.

Abstract: The main question on this study is that, in the regional integration environment of the European Union, for the internal market to get perfectibilized, it is necessary the integrated treatment of industrial property rights in the territory of the treaty, which can be characterized as the centralization of procedures and

\footnotetext{
* Universidade Federal do Rio Grande do Sul.
} 
enlargement of the territorial validity of the industrial property rights in the European Union. The economic needs of the internal market in the integration territory demand to bring to the European Union's competence the matters originally treated nationally by the member states, especially when it comes to private law. Intellectual property is a good example of it, and the European legislator is gradually bringing the regulation of this matter into the legal system of the European Union.

Keywords: European Union. Industrial Property. Private Law. Marks. Patents. Design.

\section{Introdução}

O espaço europeu está vivendo, sem dúvida, uma grande transformação em termos institucionais, e o direito está, de certa forma, liderando este processo, notadamente quando se fala em temas de direito privado, que eram tradicionalmente regulados pelo estado nacional e agora são tratados no âmbito da União Europeia. A propriedade industrial é um bom exemplo disso, e o legislador europeu está paulatinamente trazendo a regulação desta matéria para dentro do ordenamento da União.

Neste estudo estão sendo usados os termos propriedade industrial e propriedade intelectual. No entanto, eles não são sinônimos e, neste contexto, é interessante explicar a diferença entre ambos. Como bem explica Hammes ${ }^{1}$, “[...] são abrangidos pelo direito da propriedade intelectual: o direito de autor, o direito da propriedade industrial (direito do inventor, de marcas, expressões e sinais de propaganda,

1 HAMMES, Bruno Jorge. Do direito de propriedade intelectual. 3. ed. São Leopoldo: Unisinos, 2002. p. 18. 
a concorrência desleal) e o direito antitruste ou repressão ao abuso do poder econômico". Isto é, o termo propriedade industrial refere-se a uma parte da propriedade intelectual, mais especificamente aquela que trata da proteção de bens com aplicação empresarial, tais como as marcas e as patentes.

As normas de propriedade intelectual são objeto do direito internacional há muito tempo. Vários tratados operam um grande esforço de harmonização e padronização das legislações nacionais dos países signatários, como a Convenção de Berna, a Convenção de Paris, o Acordo sobre Aspectos dos Direitos de Propriedade Intelectual relacionados ao Comércio - ADPIC. Os ativos intangíveis, objeto de proteção dessas normas, são cada vez mais importantes na sociedade em processo de globalização ${ }^{2}$.

Ao mesmo tempo, percebe-se a formação de uma nova ordem jurídica de caráter internacional, o chamado Direito da Integração, que tem crescido em importância e autonomia nas últimas décadas e tem se caracterizado por extensa produção de normas jurídicas, inclusive buscando a regulação em matéria de propriedade industrial. Neste contexto o exemplo mais elaborado é a União Europeia, que será objeto deste estudo.

Os direitos de propriedade industrial são arraigados no princípio da territorialidade, isto é, cada estado concede direitos que são válidos apenas no seu território. $\mathrm{O}$ território nacional, entretanto, já não basta para as necessidades econômicas do mercado interno no espaço de integração, então se vê o seu alargamento, mas sem a perda do sentido territorial,

2 ASCENÇÃO, José de Oliveira. Sociedade da Informação e Mundo Globalizado. In: WACHOWICZ, Marcos (Org.). Propriedade Intelectual \& Internet - Uma Perspectiva Integrada à Sociedade da Informação. Curitiba: Juruá, 2002. 
cujo espaço agora é o da União Europeia. Isso se verá com relação à coexistência dos institutos nacionais responsáveis pelos registros de propriedade industrial com os institutos supranacionais e intergovernamentais.

A principal questão levantada por este estudo é a de que o mercado interno, para que se perfectibilize, necessita do tratamento integrado da propriedade industrial no território do tratado. A este tratamento integrado, que pode ser caracterizado como a centralização de procedimentos e alargamento da validade dos títulos de propriedade industrial no espaço da União Europeia, usa-se a palavra expansão. Esta significa, então, neste trabalho, trazer à competência da União matérias antes tratadas nacionalmente pelos estados membros.

Na primeira parte do trabalho, será buscada uma análise da pertinência da propriedade industrial para a implementação das liberdades econômicas fundamentais no mercado interno, bem como de que forma a proteção dos direitos de propriedade intelectual impacta na inovação e no desenvolvimento econômico. Na segunda parte do trabalho, busca-se descrever a forma e o funcionamento do sistema europeu de propriedade industrial, mais especificamente as agências que tratam das marcas, dos desenhos industriais (design) e das patentes.

\section{Relação entre Mercado Interno e Propriedade Intelectual}

Para uma integração econômica que chegue ao nível de um mercado interno, várias etapas de superação de obstáculos jurídicos devem ser transpostas. Um mercado interno pressupõe a livre circulação de pessoas, capitais, bens e 
serviços, bem como a livre concorrência. Levando-se em conta que, hodiernamente, os ativos intangíveis são bens cada vez mais valiosos ${ }^{3}$ e são regidos, em sua maioria, pelas normas de propriedade intelectual, a falta de harmonização e tratamento conjunto desses ativos dificulta, de certa forma, a livre troca de mercadorias intangíveis ou com valor intangível agregado.

O exercício do comércio de mercadorias entre os estados membros está sujeito aos influxos da propriedade industrial, uma vez que a maioria das mercadorias, especialmente as industrializadas, são identificadas por meio de marcas, e, muitas vezes, protegidas por alguma espécie de patente ${ }^{4}$. Cada estado membro da União Europeia possui sua própria legislação e suas agências de propriedade industrial, gerando uma ampla gama de possibilidades de conflito e, consequentemente, limitações às liberdades econômicas fundamentais.

Outro exemplo que ressalta a importância da propriedade intelectual para o comércio transfronteiriço é a promoção, por parte da OMC, em 1994, do acordo ADPIC - Aspectos dos Direitos da Propriedade Intelectual relacionados com o Comércio - também conhecido por sua sigla em inglês TRIPS. Este tratado estabelece padrões mínimos de proteção de propriedade intelectual aos países signatários, deixando-os livres para implementarem à sua maneira o disposto no tratado. Embora em um âmbito maior que o da integração

3 BUAINAIN, Antonio Márcio; CARVALHO, Sérgio M. Paulino. Propriedade Intelectual em um Mundo Globalizado. Trabalho apresentado na Wipo International Conference on Intellectual Property, Trade, Technological Innovation and Competitiveness, Rio de Janeiro, Brasil, jun. 2000. p 146.

4 Existem basicamente dois tipos de patentes: patentes de invenção, que protegem invenções com aplicação industrial, e patentes de modelo de utilidade, que protegem melhorias e aprimoramentos em tecnologias já existentes. 
regional, a promoção desse acordo mostra a importância do tema para o comércio. Os estados membros da União Europeia são signatários do ADPIC, o que já lhes confere algum grau de harmonização da matéria, sendo que a implementação de direitos no âmbito regional não é incompatível com a validade desse acordo.

Aos objetivos econômicos da União Europeia, foram, progressivamente, sendo somados outros, tais como o desenvolvimento econômico equilibrado dos estados membros. Nesse sentido, e também buscando planificar o entendimento sobre as inter-relações entre inovação, progresso econômico e proteção à propriedade intelectual, realiza-se uma análise do assunto também sob o ponto de vista das ciências econômicas.

\subsection{Economia e Inovação}

A proteção da propriedade intelectual está intimamente ligada à inovação ${ }^{5}$, sendo este um tema multidisciplinar por natureza. Do ponto de vista das ciências econômicas pode-se analisar a importância estratégica da inovação para o desenvolvimento da economia. Esta análise leva em conta a perspectiva schumpeteriana de que a inovação é a mola propulsora do desenvolvimento econômico.

A relação entre direito da propriedade industrial e economia é objeto de atenção dos juristas há algum tempo. Pimentel ${ }^{6}$ bem descreve as justificativas econômicas para a proteção da propriedade industrial, tratando, em especial, da

5 PELAEZ, Victor; SZMRECSÁNYI, Tamás (Org.). Economia da Inovação Tecnológica. São Paulo: Hucitec, 2006.

6 PIMENTEL, Luiz Otávio. Direito Industrial: aspectos introdutórios. Chapecó: Unoesc, 1994. 
obra de Joseph A. Schumpeter, cujo trabalho demonstrava que os ciclos econômicos estavam diretamente relacionados aos ciclos tecnológicos e que a inovação seria a mola propulsora do desenvolvimento econômico.

Sua obra parte de uma análise clássica do fenômeno capitalista em que o fluxo circular de capital seria constante e tenderia ao equilíbrio. Esta abordagem, segundo Schumpeter, não seria suficiente para explicar as crises e revoluções tecnológicas. Para ele, o caráter dinâmico do fenômeno econômico sobrepunha-se ao modelo de equilíbrio estático, isto é, a atividade do empresário inovador é que, ao introduzir novas tecnológicas, quebra a monotonia do fluxo circular adicionando uma nova dinâmica ao mercado.

Nesse ambiente, o controle concorrencial e a proteção aos direitos de propriedade industrial assumem um papel relevante no desenvolvimento de uma economia. O primeiro garante a lisura do jogo e transforma a necessidade de superação dos concorrentes em estímulo para o empresário inovar. Já os direitos de propriedade industrial garantem a proteção e o retorno do investimento realizado na criação da inovação tecnológica. A este processo de quebra do equilíbrio de um mercado pela introdução de inovações Schumpeter chamou de processo de destruição criadora ${ }^{7}$.

Neo-Schumpeterianismo 8 é um movimento de redescoberta da obra de Schumpeter e sua aplicação, especialmente para explicar a revolução tecnológica. Vários autores seguem

DUARTE, Larri. Desenvolvimento e Inovação Tecnológica: de Marx e Schumpeter às abordagens atuais. Monografia - Faculdade de Economia, Universidade Federal do Rio Grande do Sul, Porto Alegre, 2002.

8 CORAZZA, Rosana Icassatti; FRACALANZA, Paulo Sérgio. Caminhos do pensamento neo-schumpeteriano: para além das analogias biológicas. Revista Nova Economia, Belo Horizonte, v. 14, n. 2, p. 127-155, maio/ago. 2004. 
nessa linha de entendimento, de que a injeção de tecnologia tem uma alta taxa de retorno social, o benefício recebido pela sociedade em decorrência da inovação. Então faz sentido que os governos invistam em proteção da propriedade intelectual, na ideia de proteger investimentos. A experiência prática de inúmeros países demonstra que a proteção aos direitos de propriedade intelectual tem se colocado como uma importante maneira de fomentar a inovação e o desenvolvimento econômico ${ }^{9}$, protegendo quem investe em pesquisa e desenvolvimento de novos produtos e tecnologias.

Esta ideia está presente no Comunicado da Comissão ao Parlamento Europeu, ao Conselho e ao Comitê Econômico e Social Europeu - uma estratégia europeia para os direitos de propriedade industrial $^{10}$, que sugere que seja estabelecida uma estratégia europeia baseada na economia do conhecimento e no fomento à inovação e ao desenvolvimento.

Esse papel de estimulador da inovação pode ser verificado no sistema de patentes, por exemplo. Ao mesmo tempo em que este oferece um monopólio temporário para a exploração da invenção, exige que o inventor publique sua tecnologia nos escritórios de patentes, tornando-a acessível ao estudo. Esse acervo de tecnologia é designado, dentro da propriedade industrial como "estado da técnica".

No novo século que se inicia, vivemos sem dúvida uma nova fase de desenvolvimento tecnológico a que se

9 BUENO, Fabíola M. Spiandorello. A propriedade industrial como fator de desenvolvimento econômico. Revista da ABPI, Rio de Janeiro, n. 80, jan./fev. 2006.

${ }^{10}$ COMISSÃO DAS COMUNIDADES EUROPEIAS. Comunicado da Comissão ao Parlamento Europeu, ao Conselho e ao Comitê Econômico e Social Europeu - Uma estratégia europeia para os direitos de propriedade industrial. Bruxelas, 2008. 
costuma chamar de revolução informacional ${ }^{11}$, em que os ativos intangíveis, tais como as marcas e as patentes, entre outros, ocupam um papel de alto relevo. A regulação da circulação de bens e serviços, entre eles os intangíveis, é uma das principais questões do Direito da Integração, especialmente no contexto da globalização, e os sistemas de propriedade industrial são parte deste processo.

A proteção aos direitos de propriedade industrial tem também como objetivo a proteção ao consumidor, que sem essa proteção ficaria vulnerável a falsificações, além de não desfrutar dos benefícios de um mercado inovador. Além disso, quando tem-se a perspectiva do mercado interno no ambiente da União Europeia, os direitos de propriedade industrial assumem um papel de garantidores do exercício das liberdades econômicas fundamentais, como se verá a seguir.

\subsection{Liberdades Econômicas Fundamentais}

Um processo de integração econômica é também um processo dinâmico que envolve vários atores. Vários estágios de integração podem ser observados, de acordo com os objetivos e o alcance desses processos. $\mathrm{O}$ primeiro estágio seria a criação de uma zona de livre comércio, em que apenas o comércio é livre, não adentrando em questões outras. O próximo estágio compreende a união aduaneira, que adiciona características à zona de livre comércio como a adoção de uma tarifa externa comum e a supressão de barreiras aduaneiras entre os estados membros.

11 WIKIPEDIA. Revolução da Informação. Disponível em: <http://pt.wikipedia.org/ wiki/Revolução_da_informação>. Acesso em: 6 nov. 2011. 
A seguir, os estágios são a criação de um mercado comum, que pressupõe a existência de liberdades econômicas fundamentais, como ver-se-á a seguir, e a criação de um mercado interno, que aprofunda o processo do mercado comum. Cita-se ainda a união econômica e monetária e, por fim, a união política total. A cada estágio, aprofunda-se o processo de integração e novas necessidades de harmonização e uniformização jurídica vão se fazendo necessários.

Os tratados fundamentais da União Europeia previam o estabelecimento de um mercado comum, cuja principal característica é a existência das liberdades de circulação de bens, mercadorias, serviços, pessoas e capitais e as liberdades de estabelecimento e de concorrência. Mais tarde esta expressão foi substituída pela expressão mercado interno, que abarcaria não só as liberdades acima citadas, mas também a eliminação de barreiras físicas, técnicas e fiscais ${ }^{12}$.

Uma breve análise da relação da propriedade intelectual com algumas das principais liberdades econômicas é necessária, para demonstrar a importância do tratamento integrado da propriedade industrial para o êxito do mercado interno. A liberdade de circulação de bens e mercadorias é essencial para o comércio. Bens e mercadorias carregam marcas, carregam inovações (patentes). Imagine-se o caso de conflito entre marcas idênticas para produtos idênticos, concedidas para diferentes titulares por diferentes estados membros. A proteção unicamente nacional prejudicaria sobremaneira a livre circulação no espaço de integração de mercadorias identificadas através de tais marcas.

12 JAEGER JUNIOR, Augusto. Mercados comum e interno e liberdades econômicas fundamentais. Curitiba: Juruá, 2010. p. 160. 
Para a liberdade de circulação de serviços e liberdade de estabelecimento, pode ser aplicada a mesma lógica demonstrada no parágrafo anterior, pois os serviços também são prestados através de marcas, inclusive serviços de profissionais liberais. A liberdade de concorrência também é afetada pelos direitos de propriedade industrial. A Comissão Europeia é categórica ${ }^{13}$ :

[...] promover a inovação e estimular o crescimento econômico são objectivos partilhados pelo direito da propriedade industrial e pelo direito da concorrência. Uma protecção firme dos direitos de propriedade industrial deve ser acompanhada por uma aplicação rigorosa das regras da concorrência.

Fica um tanto evidente que essas liberdades podem ser afetadas em caso de uma não regulação adequada da propriedade industrial. Isso ficou muito claro para o legislador europeu, que passou a legislar sobre esta matéria para, entre outras coisas, harmonizar as legislações nacionais dos estados membros, em especial através da Diretiva 2004/48/ $\mathrm{CE}$, relativa ao respeito à propriedade intelectual, e da Diretiva 2008/95/CE, que visa a aproximar as legislações dos estados membros relacionadas às marcas e estabelece critérios comuns para a análise de processos de registro e de solução de litígios.

Os pontos 1 e 3 do preâmbulo da Diretiva 2004/48/CE são autoexplicativos.

(1) A realização do mercado interno implica a eliminação de restrições à livre circulação e distorções de concorrência, criando simultaneamente um enquadramento favorável à

${ }^{13}$ COMISSÃO DAS COMUNIDADES EUROPEIAS. Comunicado da Comissão ao Parlamento Europeu, ao Conselho e ao Comitê Econômico e Social Europeu - Uma estratégia europeia para os direitos de propriedade industrial. Bruxelas, 2008. p. 10. 
inovação e ao investimento. Nesse contexto, a protecção da propriedade intelectual é um elemento essencial para o êxito do mercado interno. A proteção da propriedade intelectual é importante não apenas para a promoção da inovação e da criação, mas também para o desenvolvimento do emprego e o reforço da competitividade.

(3) Contudo, sem os meios eficazes para fazer respeitar os direitos da propriedade intelectual, a inovação e a criação são desencorajadas e os investimentos reduzidos. Assim, é necessário assegurar que o direito material da propriedade intelectual, hoje em grande parte decorrente do acervo comunitário, seja efectivamente aplicado na Comunidade. Neste contexto, os meios para fazer respeitar os direitos de propriedade intelectual assumem uma importância capital para o êxito do mercado interno.

Como se vê, o mercado interno traz a necessidade da regulação uniforme da propriedade industrial, para evitar conflitos entre os sistemas dos estados membros e permitir a efetiva implementação das liberdades econômicas fundamentais. Ao analisarmos, na próxima parte do trabalho, as soluções encontradas para o endereçamento de tais questões, veremos que as agências europeias centralizadoras das questões relativas às marcas e às patentes encontraram formas de atuação e de institucionalização bastante diversas.

\section{Agências Europeias de Propriedade Industrial}

Neste tópico serão analisadas a forma e o funcionamento das agências europeias de propriedade industrial, mais especificamente o Escritório Europeu de Patentes ${ }^{14}$ (EPO), que trabalha em questões relativas a patentes, e o Instituto para

${ }_{14}$ EPO. Sítio Eletrônico do Escritório Europeu de Patentes. Disponível em: <http://www. epo;org/about-us/office.html>. Acesso em: 13 mar. 2012. 
a Harmonização do Mercado Interno ${ }^{15}$ (OHIM). Estas agências têm estruturas independentes e distintas e o trabalho que estas entidades realizam corrobora a hipótese de que um tratamento integrado desta matéria, isto é, em um âmbito regional, é necessário para que o mercado interno possa se estabelecer de maneira eficaz. Passa-se então à análise do Escritório Europeu de Patentes.

\subsection{Escritório Europeu de Patentes}

Na União Europeia, a proteção através da patente é atualmente assegurada por dois sistemas que não se fundamentam, nem um, nem outro, em instrumentos jurídicos comunitários. Os sistemas utilizados para este fim são os sistemas nacionais de patentes e o sistema europeu de patentes.

O Escritório Europeu de Patentes não faz parte da estrutura da União Europeia, ele é uma instituição de caráter intergovernamental e abrange também estados que não fazem parte da União Europeia. Em 1973 foi assinada em Munique a Convenção da Patente Europeia (European Patent Convention), que criou a Organização Europeia de Patentes, cujo órgão executivo é o Escritório Europeu de Patentes, criado em outubro de 1977.

Todo o sistema europeu de patentes está assentado na centralização e harmonização de procedimentos em matéria de processamento e concessão de patentes nos países membros da Organização Europeia de Patentes, que possui 38 estados membros e, além do Escritório Europeu de Patentes, possui

${ }^{15}$ OHIM. Sítio Eletrônico do Escritório de Marcas e Desenhos Industriais da União Europeia. Disponível em: <http://oami.europa.eu>. Acesso em: 27 mar. 2012. 
também o Conselho Administrativo, que é formado pelos representantes dos estados contratantes e exerce poderes de legislar em nome da Organização, bem como é responsável pela fiscalização do EPO e pela elaboração das políticas estratégicas. $\mathrm{O}$ conselho funciona nos idiomas inglês, francês e alemão, tendo sessões trimestrais.

Existem, atualmente, três maneiras de se solicitar uma patente na Europa. A primeira delas, por óbvio, é a via nacional, em que um pedido de patente é realizado diretamente à autoridade nacional responsável. Este pedido terá validade territorial limitada ao território do estado responsável pelo processamento e concessão. Percebe-se que encaminhar individualmente um pedido de patente para cada estado membro da União Europeia é complexo e caro, motivo pelo qual se pensou em uma solução, que foi solicitar os pedidos 210 de patente através do Escritório Europeu de Patentes.

Através desta via europeia, em que se faz o pedido de patente através do EPO, esse pedido é submetido a um exame preliminar, de caráter regional. É somente então que o pedido é repassado aos escritórios nacionais de interesse da parte solicitante. Despesas de tradução de documentos somente serão necessárias após o exame preliminar, facilitando o processamento e a proteção da patente. Este procedimento unifica a data de solicitação para todos os estados em que a patente for solicitada.

A terceira via possível de solicitação de patente na Europa é a via internacional, disponível através do Tratado de Cooperação em matéria de Patentes (PCT), firmado no âmbito da OMPI ${ }^{16}$ - Organização Mundial da Propriedade

${ }_{16}$ OMPI. Sítio Eletrônico da Organização Mundial da Propriedade Intelectual. Disponível em: <http://www.wipo.int/pct/pt/index.html>. Acesso em: 27 mar. 2012. 
Intelectual - que é uma agências especializadas da ONU, cujos objetivos são promover a proteção da propriedade intelectual através da cooperação entre os estados. Faz-se uma solicitação internacional única, nos mesmos moldes da via europeia, e, após o exame preliminar, se escolhe em quais estados se vai querer buscar a proteção da patente.

Apesar de tudo, concessão de patentes na Europa continua sendo um direito territorial dos estados. Esta parcela de soberania não foi ainda cedida às instituições comunitárias. Isso, porém, está prestes a mudar ${ }^{17}$, com parte da estratégia da União Europeia para a proteção da propriedade industrial, deverá ser criado, nos moldes da agência europeia de marcas e desenhos industriais, uma patente europeia, cuja validade territorial estenda-se a todos os Estados membros. Enquanto a patente europeia não se torna uma realidade, a Organização Europeia de Patentes segue seu papel de facilitadora das demandas patentárias frente ao mercado interno.

\footnotetext{
${ }^{17}$ EXAME. UE cria patente europeia após 40 anos de divisões. Disponível em: <http:// exame.abril.com.br/economia/noticias/ue-cria-patente-europeia-apos-40-anos-de-divisoes>. "Bruxelas -A União Europeia (UE) chegou a um acordo nesta sexta-feira para criar uma patente única europeia, anunciou o presidente do bloco, Herman Van Rompuy, o que acaba com 40 anos de divisões. A Europa tentava há quatro décadas estabelecer um sistema de patentes único que proteja com apenas um registro todas as criações de cada um dos países membros. A nova instituição de patentes europeia terá três sedes: a principal ficará em Paris, onde serão registradas as patentes dos setores têxtil, de papel e eletricidade. Munique administrará os registros de engenharia mecânica, luz, calefação, armas, explosivos e materiais de construção. Londres registrará as patentes de biotecnologia, farmacêuticas, metalúrgicas e químicas." Acesso em: 30 jun. 2012.
} 


\subsection{Instituto para a Harmonização do Mercado Interno}

O instituto europeu responsável pelas marcas e pelos desenhos industriais foi criado pelo Regulamento 40/94/CE, que estabeleceu também a criação da marca comunitária e do desenho industrial comunitário. Doravante, neste trabalho, quando falar-se de marca comunitária, presumir-se-á que se está falando também dos desenhos industriais, que não serão mencionados, para preservar a fluidez do texto. A marca comunitária tem um caráter unitário e um efeito unitário dentro da União Europeia. Isto é, ela irradia efeitos sobre todo o território integrado, residindo aqui sua primeira grande diferença com a patente, cuja competência territorial ainda é nacional. A marca comunitária é registrada e administrada pelo Instituto para a Harmonização do Mercado Interno,

212 sediado em Alicante, na Espanha, e passaremos a denominá-lo OAMI, sua sigla no idioma espanhol.

O uso da marca comunitária é estimulado pela União Europeia, e verifica-se isso pela necessidade de os escritórios nacionais utilizarem a base de dados comunitária para verificar anterioridades na concessão de marcas nacionais. O OAMI não derroga os poderes das autoridades nacionais em matéria de marcas e desenhos industriais, mas atua em cooperação com eles. As solicitações de registro de marcas comunitárias podem ser realizadas diretamente no OAMI, ou em qualquer autoridade nacional de um estado membro da União Europeia, que coopera atuando como uma agência avançada do instituto europeu e reenviando àquele instituto o pedido de registro.

Em termos de economia de recursos, praticidade e eficácia, a marca comunitária representa um grande avanço 
para a efetivação do mercado interno, trazendo uma maior confiabilidade e segurança jurídica ao se investir nestes ativos de propriedade industrial. O sistema europeu de marcas é um sistema híbrido em que as autoridades nacionais complementam a atuação do OAMI. A competência para julgar infrações às marcas comunitárias, por exemplo, é das cortes nacionais ${ }^{18}$, que aplicam a legislação comunitária e nacional para a correição das lides.

A marca comunitária confere ao seu titular o direito de uso exclusivo do signo marcário em todo o território da União Europeia e permite impedir o uso por terceiros não autorizados, de uma marca igual ou parecida para designar produtos ou serviços idênticos ou semelhantes. Essa proteção é conseguida mediante a apresentação de um único pedido, em um único idioma, com um procedimento e centro administrativo únicos. Isso simplifica sobremaneira a proteção desses ativos e reduz o custo de transação no território do mercado interno.

O OAMI é uma agência da União Europeia, cuja supervisão cabe à Comissão Europeia. No entanto, o instituto possui autonomia financeira, administrativa e legal em relação à Comissão. O OAMI possui em sua estrutura, entre outros órgãos administrativos, uma Câmara de Apelações (Boards of Appeal), que é responsável por decisões de primeira instância relacionadas às matérias de marcas e desenhos industriais.

Embora façam parte da estrutura do OAMI, os membros da Câmara de Apelações têm independência e autonomia

${ }_{18}$ OHIM. National Law Relating to the Community Trade Mark and the Community Design. Information Brochure of the Office for Harmonization in the Internal Market (Trade Mark and Design). 3. ed. Alicante: OHIM, 2006. 
para julgar os casos. A revisão dos casos submetidos à câmara é de responsabilidade do Tribunal de Primeira Instância e do Tribunal de Justiça da União Europeia. O OAMI representa um avanço para o êxito da garantia das liberdades econômicas fundamentais na União Europeia.

\section{Considerações Finais}

Verificou-se ao longo deste trabalho que os sistemas de propriedade industrial guardam uma íntima relação com o exercício das liberdades econômicas fundamentais no plano da União Europeia. Ao mesmo tempo em que os direitos de propriedade industrial estão ligados à estruturação do mercado interno, eles também contribuem para o desenvolvimento econômico no espaço integrado.

Frente a essas necessidades do mercado interno, e às necessidades de prover este mercado de ferramentas que estimulem a inovação tecnológica dos agentes econômicos, a União Europeia está vivendo um movimento de trazer para o seio da sua instituição a regulação da propriedade industrial. O território objeto desses ativos intangíveis tão importantes mudou, o território nacional perde força frente ao território da União.

Este movimento, a que se chamou de expansão do direito de propriedade industrial na União Europeia, foram analisadas sua legitimidade e suas justificativas. $\mathrm{O}$ tratamento integrado das marcas, dos desenhos industriais e patentes, por parte da União Europeia, é um movimento natural, tendo em vista a ampliação e o aprofundamento do mercado. A recente aprovação da criação de um sistema europeu de 
patentes que esteja vinculado à estrutura da união e que, a exemplo das marcas e dos desenhos industriais comunitários, estenda a aplicação territorial do direito de patentes, é uma prova concreta de que esse movimento é necessário para o êxito do mercado interno.

O acompanhamento dos próximos passos da União Europeia em matéria de propriedade intelectual ajudará a definir com mais precisão o cenário de regulação destes direitos, mas fica evidente que o caminho foi apontado em direção ao tratamento supranacional da questão e à consequente europeização das normas e instituições de propriedade industrial.

\section{Referências}

ASCENÇÃO, José de Oliveira. Questões Problemáticas em sede de Indicações Geográficas e Denominações de Origem no Direito Português. Revista da ABPI, Rio de Janeiro, n. 81, 2006.

. Sociedade da Informação e Mundo Globalizado. In: WACHOWICZ, Marcos (Org.). Propriedade Intelectual \& Internet Uma Perspectiva Integrada à Sociedade da Informação. Curitiba: Juruá, 2002.

BASSO, Maristela. O Direito Internacional da Propriedade Intelectual. Porto Alegre: Livraria do Advogado, 2000.

BUAINAIN, Antonio Márcio; CARVALHO, Sérgio M. Paulino. Propriedade Intelectual em um Mundo Globalizado. Wipo International Conference on Intellectual Property, Trade, Technological Innovation and Competitiveness. Rio de Janeiro, 2000.

BUENO, Fabíola M. Spiandorello. A propriedade industrial como fator de desenvolvimento econômico. Revista da ABPI, Rio de Janeiro, n. 80, jan./fev. 2006.

COMISSÃO DAS COMUNIDADES EUROPEIAS. Comunicado da Comissão ao Parlamento Europeu, ao Conselho e ao Comitê 
Econômico e Social Europeu - Uma estratégia europeia para os direitos de propriedade industrial. Bruxelas, 2008.

CONSELHO EUROPEU. Regulamento n. 40/94/CE, de 20 de dezembro de 1993, sobre a marca comunitária. Bruxelas, 1994.

CORAZZA, Rosana Icassatti; FRACALANZA, Paulo Sérgio. Caminhos do pensamento neo-schumpeteriano: para além das analogias biológicas. Revista Nova Economia, Belo Horizonte, v. 14, n. 2, p. 127-155, maio/ago. 2004.

CORREA, Carlos M. Acordo TRIPS: Quanta Flexibilidade há para Implementar os Direitos de Patente. In: DAL RI JUNIOR, Arno; OLIVEIRA, Odete Maria de (Org.). Direito Econômico em Expansão: desafios e dilemas. Ijuí: Unijuí, 2003.

DUARTE, Larri. Desenvolvimento e Inovação Tecnológica: de Marx e Schumpeter às abordagens atuais. Monografia - Faculdade de Economia, Universidade Federal do Rio Grande do Sul, Porto Alegre, 2002.

EPO. Sítio Eletrônico do Escritório Europeu de Patentes. Disponível em: <http://www.epo;org/about-us/office.html>. Acesso em: 13 mar. 2012.

EUROPEAN COMMISSION. Analysis of the application of Directive 2004/48/EC of the European Parliament and Council of 29 April 2004 on the enforcement of intellectual property rights in the Member States. Bruxelas, 2010.

. Public Hearing on Directive 2004/48/EC and the challenges posed by the digital environment. Bruxelas, 2011.

EUROPEAN PARLIAMENT and COUNCIL. Directive 2008/95/EC of the Parliament and of the Council, of 22 October 2008 to approximate the laws of the Member States relating to trade marks. Strasbourg, 2008.

EXAME. UE cria patente europeia após 40 anos de divisões. Disponível em: <http://exame.abril.com.br/economia/noticias/ue-cria-patente-europeia-apos-40-anos-de-divisoes>. Acesso em: 30 jun. 2012.

FERNÁNDEZ MASIÁ, Enrique. Protección Internacional de la Propriedad Industrial y Intelectual. In: PIMENTEL, Luiz Otávio; ESPLUGUES MOTA, Carlos; BARRAL, Welber Oliveira (Org.). Direito Internacional Privado: União Européia e Mercosul. Florianópolis: Fundação Boiteux, 2007. 
FROEHLINGER, Margot. Conclusions. Industrial Property Rights Conference Strasbourg. Estrasburgo, 2008.

HAMMES, Bruno Jorge. O direito de Propriedade Intelectual. 3. ed. São Leopoldo: Editora Unisinos, 2002.

JAEGER JUNIOR, Augusto. Mercados comum e interno e liberdades econômicas fundamentais. Curitiba: Juruá, 2010.

JAGUARIBE, Roberto et al. Perspectivas do Desenvolvimento Internacional da Proteção da Propriedade Intelectual no Mercosul. In: Anais [do] Seminário Nacional da Propriedade Intelectual. Rio de Janeiro: ABPI, 2006.

LEIS, Sandra. A Organização Mundial do Comércio e a Propriedade Intelectual. Revista da ABPI, Rio de Janeiro, n. 87, 2007.

MAX PLANK INSTITUTE FOR INTELLECTUAL PROPERTY AND COMPETITION LAW. Study on the Overall Functioning of the European Trade Mark System. Munich, 2011.

MERCOSUL, CMC/DEC № 16/98. Protocolo de Harmonização de Normas em Matéria de Desenhos Industriais. XV CMC - Rio de Janeiro, 10 dez. 1998.

MERCOSUL, CMC/DEC № 8/95. Protocolo de Harmonização de Normas sobre Propriedade Intelectual no MERCOSUL, em matéria de Marcas, Indicações de Procedência e Denominações de Origem. VIII CMC - Assunção, 5 ago. 1995.

OHIM. National Law Relating to the Community Trade Mark and the Community Design. Information Brochure of the Office for Harmonization in the Internal Market (Trade Mark and Design). 3. ed. Alicante: OHIM, 2006.

. Sítio Eletrônico do Escritório de Marcas e Desenhos Industriais da União Europeia. Disponível em: <http://oami.europa.eu>. Acesso em: 27 mar. 2012.

OLAVO, Carlos. A Protecção do "Trade Dress" no Direito Português e no Direito Comunitário. Revista da ABPI, Rio de Janeiro, n. 82, maio/jun. 2006.

OMPI. Sítio Eletrônico da Organização Mundial da Propriedade Intelectual. Disponível em: <http://www.wipo.int/pct/pt/index.html>. Acesso em: 27 mar. 2012. 
PARLAMENTO EUROPEU e CONSELHO DA UNIÃO EUROPEIA. Directiva 2004/48/CE do Parlamento Europeu e do Conselho, de 29 de abril de 2004, relativa ao respeito dos direitos de propriedade intelectual. Estrasburgo, 2004.

PELAEZ, Victor; SZMRECSÁNYI, Tamás (Org.). Economia da Inovação Tecnológica. São Paulo: Hucitec, 2006.

PIMENTEL, Luiz Otávio. Direito Industrial: aspectos introdutórios. Chapecó: Unoesc, 1994.

REGÚNAGA, Marcelo; LORENZO, Natividad. O Sistema Europeu de Patentes: Sistemas de Certificação na União Europeia e Práticas Úteis aos Países do Mercosul. Buenos Aires: Biotecsur, 2008.

TIBURCIO, Carmen; BARROSO, Luis Roberto (Org.). O Direito Internacional Contemporâneo - Estudos em Homenagem ao Professor Jacob Dolinger. Rio de Janeiro: Editora Renovar, 2006.

UNIÃO EUROPEIA. Sítio Eletrônico Oficial da União Europeia. Disponível em: <http://europa.eu/>. Acesso em: 27 mar. 2012.

WIKIPEDIA. Revolução da Informação. Disponível em: <http://pt. wikipedia.org/wiki/Revolução_da_informação>. Acesso em: 6 nov. 2011. 


\section{Relativização da Coisa Julgada Inconstitucional em Face da Segurança Jurídica e da Justiça das Decisões Judiciais}

Relativization of Unconstitutional Res Judicata in Face of Legal Certainty and Justice of Judgments

Elis Regina Sousa Miranda*

Resumo: Durante muito tempo, a coisa julgada foi concebida como um instituto intangível, somente passível de relativização nas hipóteses de ação rescisória. No entanto, este instituto, embora indispensável para a segurança jurídica, passou a ser contestado devido a decisões que acarretavam evidentes injustiças e/ou inconstitucionalidades. Nesse contexto, o presente artigo pretendeu sistematizar as teses existentes acerca da relativização da coisa julgada inconstitucional, identificando os posicionamentos favoráveis e desfavoráveis. Ademais, objetivou-se identificar se o ordenamento jurídico atual apresenta mecanismos capazes de solucionar o problema. Caso contrário, objetivou-se analisar a viabilidade das teses de relativização atípica e buscar uma solução que concilie os ideais de segurança jurídica e justiça.

Palavras-chave: Coisa Julgada. Relativização. Segurança Jurídica. Justiça. Constituição Federal.

\footnotetext{
1 Artigo extraído da Monografia apresentada ao curso de Direito da Universidade Federal de Viçosa como requisito para obtenção do título de bacharel em Direito e aprovada pela banca examinadora composta pelo Orientador Gabriel Pires e pelos Professores Gláucio Inácio da Silveira e Regel Antônio Ferrazza, em 25 de abril de 2013.

* Universidade Federal de Viçosa.
} 
Abstract: For a long time the res judicata was conceived as an intangible institute only capable of being relativized in cases of rescission action. However, this institute, although indispensable for legal certainty, came to be challenged due to decisions that entailed obvious injustices and/or unconstitutionalities. In this context, this study aimed to systematize the existing theories about the relativization of unconstitutional res judicata, identifying favorable and unfavorable positions. Furthermore, this study aimed to identify whether the current law has mechanisms to solve the problem. Otherwise, it aimed to examine the feasibility of the atypical relativization theses and to seek a solution that reconciles the ideals of legal certainty and justice.

Keywords: Res Judicata. Relativization. Legal Certainty. Justice. Federal Constitution.

\section{Introdução}

As transformações no direito processual civil moderno, especialmente no que tange ao denominado processo civil de resultados, trouxeram consigo exigências de efetividade e de justiça. ${ }^{2}$ A própria noção de processo adquiriu novos contornos, passando a pressupor a noção de resultado justo, compatível com a Constituição Federal e o mais próximo possível da verdade real. ${ }^{3}$

2 “O direito processual moderno é um sistema orientado à construção de resultados justos. A ideologia do processualista contemporâneo, conhecida como processo civil de resultados, leva à necessária revisão de diversos conceitos que pareciam firmemente estabelecidos no panteão dos dogmas jurídicos." CÂMARA, Alexandre Freitas. Relativização da coisa julgada material. In: NASCIMENTO, Carlos Valder do (Coord.). Coisa julgada inconstitucional. 4. ed. Rio de Janeiro: América Jurídica, 2003. p. 202.

3 "O Direito Processual Civil mudou e a busca da verdade real, como meio de se alcançar a justiça e concretizar o anseio do justo processo legal, é uma exigência de tempos modernos" (grifo do autor). THEODORO JÚNIOR, Humberto; FARIA, 
Nesse contexto, doutrina e tribunais, ao depararem-se com situações em que a manutenção da coisa julgada colidia com o senso de justiça social, começaram a defender uma mitigação do instituto. Assim, embora seja inegável a relevância da coisa julgada para a manutenção da estabilidade da ordem jurídica, vislumbrou-se a necessidade de compatibilizá-la com outros direitos constitucionalmente previstos e com novos anseios sociais. No Brasil, a referida tese ganhou maior força no ano de 2011, quando o STF (Supremo Tribunal Federal) reconheceu a possibilidade de relativização da coisa julgada no caso de ações de estado. ${ }^{4}$

Diante dessas transformações, o presente artigo pretende analisar a temática da relativização da coisa julgada inconstitucional. A escolha do tema deve-se à importância do instituto da coisa julgada e de todas as suas implicações no ordenamento jurídico brasileiro. Ao mesmo tempo em que é preciso garantir a definitividade e imutabilidade das decisões judiciais, em prol da segurança jurídica e da estabilidade das relações sociais, deve-se assegurar aos jurisdicionados que as decisões sejam justas e compatíveis com a Constituição Federal.

Juliana Cordeiro de. A coisa julgada inconstitucional e os instrumentos processuais para o seu controle. In: NASCIMENTO, Carlos Valder do (Coord.), op. cit., p. 91. "A propósito do problema da obtenção da verdade no processo (ainda que adjetivada como verdade processual, já que a verdade no processo sempre se resolve num juízo de verossimilhança), impende observar desde logo que a sua colocação como um dos objetivos ideais da prova judiciária oferece-se como uma condição insuprimível para que o processo cumpra a contento o seu desiderato maior de lograr a justiça do caso decidendo". MITIDIERO, Daniel. Colaboração no processo civil: pressupostos sociais, lógicos e éticos. 2 ed. São Paulo: Editora Revista dos Tribunais, 2011. p. 108.

4 BRASIL. Supremo Tribunal Federal. Recurso Extraordinário n. 363.889/DF. Recorrentes: Ministério Público do DF e D.G.S. Recorrido: G.F.R. Relator: Dias Toffoli. Brasília, 2 de junho de 2011. 
Inegável é a relevância do debate, envolvendo questionamentos vários, como a própria função do Direito no âmbito das relações sociais; o fundamento de validade das decisões judiciais; o alcance da norma contida no artigo $5^{\circ}$, XXXVI, da Constituição Federal, e a ponderação entre o anseio de legitimidade da ordem jurídica e a necessidade de se preservar a segurança.

$\mathrm{O}$ presente artigo pretende, primeiramente, promover uma sistematização das diversas teses existentes acerca da relativização da coisa julgada inconstitucional, identificando os posicionamentos favoráveis e desfavoráveis, os requisitos e os instrumentos apontados pela doutrina. Posteriormente, pretende-se verificar se a legislação processual civil de lege lata ${ }^{5}$ já solucionou o problema da sentença inconstitucional transitada em julgado. Caso a resposta seja negativa, pretende-se analisar a viabilidade da relativização atípica da coisa julgada inconstitucional e buscar uma solução que concilie os ideais de segurança jurídica e justiça.

Por derradeiro, faz-se necessário registrar duas observações de ordem terminológica. A primeira delas diz respeito a uma advertência feita por José Carlos Barbosa Moreira quanto ao termo relativização. Segundo o autor, referido termo transmite a ideia de ser a coisa julgada absoluta, o que, evidentemente, não é verdade, tendo em vista as hipóteses de ação rescisória há muito previstas no ordenamento jurídico. ${ }^{6}$ Desse modo, faz-se necessário assinalar que, apesar da inadequação do termo, ele é utilizado pela maioria dos

\footnotetext{
5 A expressão latina "de lege lata" significa "da lei existente" e se contrapõe à expressão "de lege ferenda", que significa "da lei a ser criada".

6 MOREIRA, José Carlos Barbosa. Temas de direito processual civil (nona série). São Paulo: Saraiva, 2007. p. 235-236.
} 
doutrinadores com o intuito de referirem-se à possibilidade de relativização da coisa julgada independentemente dos instrumentos legalmente previstos.

Outros doutrinadores, porém, a fim de evitarem o equívoco que o termo poderia causar, utilizam a expressão relativização atípica com o intuito de se referirem exclusivamente às hipóteses de relativização da coisa julgada além daquelas tipificadas na lei. No presente artigo, objetivando-se simplificar e seguir a terminologia da maioria dos doutrinadores, utilizar-se-á, em diversos momentos, somente o termo relativização, o qual deve ser compreendido abstraindo-se as hipóteses legais que já ensejam a revisão da coisa julgada.

A segunda observação diz respeito à expressão coisa julgada inconstitucional. Ela é utilizada pela maioria dos doutrinadores de um modo geral e indiscriminado. Outros, porém, diferenciam coisa julgada inconstitucional de coisa julgada injusta inconstitucional, utilizando a primeira expressão para referirem-se à coisa julgada que abarca sentenças de mérito que tenham como fundamento uma norma declarada inconstitucional pelo STF e utilizando a segunda expressão para se referirem à coisa julgada que acoberta sentenças que ofendem diretamente valores constitucionais essenciais ao Estado Democrático de Direito. Pelas mesmas razões expostas em relação à preferência quanto ao termo relativização, no presente artigo, não se adotará a distinção acima citada, utilizando-se somente a expressão coisa julgada inconstitucional. 


\section{Da Constituição Federal}

\subsection{Controle de Constitucionalidade dos Atos Judiciais}

Conforme a teoria desenvolvida por Hans Kelsen, o Direito organiza-se em uma estrutura hierárquica, segundo a qual as normas jurídicas situam-se em níveis distintos, de modo que as inferiores precisam fundamentar sua validade nas superiores. Essa linha de regressão às normas mais superiores do sistema jurídico conduz, inevitavelmente, à última norma positiva, a Constituição Federal. ${ }^{7}$

Sendo a Constituição Federal o fundamento de validade de todo o ordenamento, conclui-se que nenhum ato jurídico pode subsistir validamente se estiver contaminado pelo vício da inconstitucionalidade. Com efeito, a supremacia da Constituição não se dá somente em relação aos atos normativos, abrangendo, obviamente, as decisões proferidas pelo Poder Judiciário.

Apesar dessa concepção estar consolidada atualmente, durante muitos anos, inexistiu qualquer preocupação quanto ao controle de constitucionalidade dos atos judiciais, de modo que as atenções sempre se detiveram nos atos legislativos desconformes com a Constituição. Assim, de acordo com Humberto Theodoro Júnior e Juliana Cordeiro de Faria, tal cenário deu ensejo à equivocada ideia de intangibilidade das decisões judiciais. ${ }^{8}$

7 KELSEN, Hans. Teoria Pura do Direito. 6. ed. São Paulo: Martins Fontes, 1998. p. 246.

8 Nesse sentido, dissertam os doutrinadores: “Com efeito, institucionalizou-se o mito da impermeabilidade das decisões judiciais, isto é, de sua imunidade a ataques, ainda que agasalhasem inconstitucionalidade, especialmente após operada a coisa julgada e ultrapassado, nos variados ordenamentos, o prazo para a sua impugnação. A coisa julgada, neste cenário, transformou-se na expressão 
Acerca dessa questão, relevante é a lição de Paulo Otero, o qual ensina que se a lei não é imune ao controle de constitucionalidade, as decisões judiciais também não haveriam de ser. ${ }^{9}$ Desse modo, embora comumente a referência ao controle de constitucionalidade seja feita somente em relação às leis, não se pode olvidar que os atos dos três Poderes - Executivo, Legislativo e Judiciário - só poderão subsistir validamente se estiverem em conformidade com a Constituição Federal. ${ }^{10}$

\subsection{Tratamento Constitucional da Coisa Julgada}

A única alusão feita pela Constituição Federal à coisa julgada está contida no artigo $5^{\circ}$, XXXVI, o qual dispõe que "[...] a lei não prejudicará o direito adquirido, o ato jurídico perfeito e a coisa julgada". O alcance da referida norma é objeto de discussão doutrinária, dando ensejo a duas correntes.

A primeira corrente, na qual se enquadra o doutrinador Paulo Roberto de Oliveira Lima, defende que a proteção constitucional da coisa julgada não impede a existência de remédio jurídico-processual hábil a desconstituí-la, posto que tão somente protege o instituto em face de alterações legislativas subsequentes. ${ }^{11}$

máxima a consagrar os valores de certeza e segurança perseguidos no ideal do Estado de Direito. Consagra-se, assim, o princípio da intangibilidade da coisa julgada, visto, durante vários anos, como dotado de caráter absoluto". THEODORO JÚNIOR, Humberto; FARIA, Juliana Cordeiro de, op. cit., p. 72.

9 OTERO, Paulo. Ensaio sobre o caso julgado inconstitucional. Lisboa: Lex, 1993. p. 10.

${ }^{10}$ BARROSO, Luís Roberto. O controle de constitucionalidade no direito brasileiro. 4. ed. São Paulo: Saraiva, 2009. p. 2.

${ }_{11}$ Paulo Roberto de Oliveira Lima considera que a proteção constitucional conferida à coisa julgada é mais tímida do que se supõe, de modo que não há impedimentos para a existência de restrições e de instrumentos de revisão dos julgados, pois, se assim fosse, a ação rescisória e a revisão criminal seriam institutos inconstitu- 
A segunda corrente, na qual se enquadram os doutrinadores Alexandre Freitas Câmara e Cândido Rangel Dinamarco $^{12}$, defende que o tratamento constitucional destinado ao instituto da coisa julgada não se limita a garantir a sua proteção em face da retroatividade da lei, abrangendo todo instrumento jurídico que venha a prejudicá-lo. No entanto, Câmara adverte que a coisa julgada, embora seja uma garantia constitucional, não é absoluta e imune a qualquer espécie de relativização. ${ }^{13}$

Percebe-se que o tratamento constitucional da coisa julgada constitui um tema bastante controvertido na doutrina processual brasileira, sendo que o entendimento da norma consagrada no artigo $5^{\circ}$, XXXVI, da Constituição Federal, influi diretamente na possibilidade ou não de relativização.

Nesse contexto, entendemos que, diante da proteção constitucional da coisa julgada no rol dos direitos e garantias fundamentais e diante do reconhecimento do Estado Democrático de Direito - o qual tem como base a segurança jurídica - como um princípio fundamental da república, não há como negar ao referido instituto o caráter de cláusula pétrea, conforme disposto no artigo $60, \S 4^{\circ}, \mathrm{IV}^{14}$

cionais. Para o autor, a Constituição Federal consagra a coisa julgada como uma das facetas do princípio da não surpresa ou irretroatividade da lei. LIMA, Paulo Roberto de Oliveira. Contribuição à teoria da coisa julgada. São Paulo: RT, 1997. p. 86.

12 Cândido Rangel Dinamarco defende que a proteção constitucional da coisa julgada não se destina exclusivamente ao legislador, de modo que o constituinte disse menos do que queria: "Por força da coisa julgada, não só o legislador carece de poderes para dar nova disciplina a uma situação concreta já definitivamente regrada em sentença irrecorrível, como também os juízes são proibidos de exercer a jurisdição outra vez sobre o caso e as partes já não dispõem do direito de ação ou de defesa como meios de voltar a veicular em juízo a matéria já decidida." DINAMARCO, Cândido Rangel. A Nova Era do Processo Civil. São Paulo: Malheiros, 2003. p. 245.

13 CÂMARA, Alexandre Freitas, op. cit., p. 193.

${ }^{14}$ GÓES, Gisele Santos Fernandes. A "Relativização" da Coisa Julgada: exame crítico (exposição de um ponto de vista contrário). Revista de Processo, São Paulo, ano 31, n. 135, p. 249-265, maio 2006. 
Sendo a coisa julgada uma cláusula pétrea, entendemos que ela merece proteção não apenas em face das leis, mas também em face das decisões judiciais. Com efeito, tanto os legisladores como os julgadores estão proibidos de violar a coisa julgada, até mesmo porque, tendo em vista o princípio da separação e harmonia dos poderes, previsto no artigo $2^{\circ}$ da Constituição Federal, não há motivos para se estabelecer um tratamento diferenciado que beneficie o Poder Judiciário.

Todavia, ressalta-se que o referido entendimento não inviabiliza toda e qualquer alteração da disciplina processual acerca da coisa julgada, uma vez que o artigo $60, \S 4^{\circ}$ c/c artigo $60, \S 4^{\circ}, I V$, são claros ao dispor que não será objeto de deliberação a proposta de emenda tendente a abolir os direitos e garantias individuais. Assim, inicialmente, é perfeitamente possível uma eventual alteração legislativa do artigo 485, do Código de Processo Civil, desde que ela não ocasione a destruição ou profunda mudança de identidade do instituto da coisa julgada.

\section{Confronto entre Segurança Jurídica e Justiça}

\subsection{Breve Histórico da Relativização}

O movimento de relativização da coisa julgada além das hipóteses autorizadoras da ação rescisória foi motivado por algumas decisões que, conquanto tivessem sido abarcadas pelo trânsito em julgado, continham uma evidente injustiça e/ou inconstitucionalidade.

Isso ocorreu, principalmente, nas demandas expropriatórias em que se buscava uma justa indenização e nas 
demandas de investigação de paternidade. Nas primeiras, o sentimento de evidente injustiça ora decorreu da própria interpretação do termo justa indenizaçãa ${ }^{15}$, ora decorreu da constatação fática de estar sendo imposta ao erário uma dupla cobrança pelo imóvel desapropriado, o qual já pertencia ao órgão expropriante. ${ }^{16}$

Nas demandas investigatórias de paternidade, ${ }^{17}$ o sentimento de injustiça e, de certa forma, de descrédito em relação à decisão judicial, emanava da superveniente realização de um exame de DNA, o qual apontava uma paternidade diversa daquela que havia sido reconhecida pelo Poder Judiciário.

A partir de então, além dos tradicionais instrumentos de revisão da coisa julgada, a doutrina passou a vislumbrar e instituir meios atípicos de relativização, visando a desconstituir a coisa julgada inconstitucional.

\subsection{Requisitos para a Relativização}

A doutrina favorável à relativização defende que a coisa julgada, apesar de constituir um importante instrumento de tutela da segurança jurídica, não é, em si, um valor

${ }^{15}$ BRASIL. Superior Tribunal de Justiça. Recurso Especial n. 765.566/RN. Recorrente: Instituto Nacional de Colonização e Reforma Agrária - INCRA. Recorrido: Estado do RN. Relator: Luiz Fux. Brasília, 19 de abril de 2007.

${ }^{16}$ BRASIL. Superior Tribunal de Justiça. Recurso especial n. 240.712/SP. Recorrente: Fazenda do Estado de SP. Recorridos: James Ross e outros. Relator: José Delgado. Brasília, 15 de fevereiro de 2000.

17 Em relação às demandas de investigação de paternidade, cumpre registrar que tramita na Câmara dos Deputados o Projeto de Lei n. 6960/02, o qual prevê, no artigo $1.606, \S 2^{\circ}$, que referidas demandas somente ficarão abarcadas pelo trânsito em julgado após realização do exame de DNA, ressalvada a hipótese de recusa à submissão ao referido exame pericial. BRASIL. Congresso. Câmara dos Deputados. Projeto de lei n. 6960/02. 
absoluto. A ideologia desse movimento é muito bem sintetizada na seguinte frase de Cândido Rangel Dinamarco: “[...] não é legítimo eternizar injustiças a pretexto de evitar a eternização de incertezas" (grifo do autor). ${ }^{18}$

Entre os defensores da tese da relativização da coisa julgada inconstitucional, constatamos a existência de três correntes no que tange à formulação de requisitos. Na primeira corrente, enquadramos o ministro José Augusto Delgado ${ }^{19}$ e a doutrinadora Maria Berenice Dias ${ }^{20}$, os quais consideram que a injustiça da decisão judicial constitui requisito suficiente para ensejar a relativização da coisa julgada.

Na segunda corrente, enquadramos os doutrinadores Alexandre Freitas Câmara ${ }^{21}$, Humberto Theodoro Júnior e Juliana Cordeiro de Faria ${ }^{22}$, os quais, embora favoráveis à

${ }^{18}$ DINAMARCO, Cândido Rangel, op. cit., p. 227.

19 "A grave injustiça não deve prevalecer em época nenhuma, mesmo protegida pelo manto da coisa julgada, em um regime democrático, porque ela afronta a soberania da proteção da cidadania." DELGADO, José Augusto. Efeitos da coisa julgada e os princípios constitucionais. In: NASCIMENTO, Carlos Valder do (Coord.), op. cit., p. 54.

${ }^{20}$ Maria Berenice Dias defende que a revisão do encargo alimentar fixado será sempre possível quando houver o desatendimento do trinômio proporcionalidade-possibilidade-necessidade. Assim, disserta a doutrinadora: "Mesmo que não tenha ocorrido alteração, quer das possibilidades do alimentante, quer das necessidades do alimentado, possível a adequação a qualquer tempo. Essa é a única forma de impedir a perpetuação de flagrantes injustiças. Ora, se fixado o montante dos alimentos sem que, por exemplo, saiba o credor dos reais ganhos do devedor, ao tomar conhecimento de que o valor estabelecido desatende ao princípio da proporcionalidade, cabe buscar a redefinição, sem que a pretensão esbarre na coisa julgada." DIAS, Maria Berenice. Manual de Direitos das Famílias. 5. ed. São Paulo: Editora Revista dos Tribunais, 2009. p. 531.

${ }^{21}$ CÂMARA, Alexandre Freitas, op. cit., p. 195.

22 "A tese que sustentamos, todavia, não se ampara apenas e singelamente na injustiça da sentença. O que pretendemos é que há um tipo de injustiça muito mais grave do que o decorrente da ilegalidade ou da contravenção ética. Trata-se da vulneração pela sentença de algum preceito ou mandamento constitucional." THEODORO JÚNIOR, Humberto; FARIA, Juliana Cordeiro de, op. cit., p. 108. 
relativização da coisa julgada, alegam que a mesma não pode ser admitida sob o mero argumento de injustiça, devendo estar restrita às hipóteses de sentenças inconstitucionais transitadas em julgado.

$\mathrm{Na}$ terceira corrente, enquadramos o doutrinador Cândido Rangel Dinamarco ${ }^{23}$, segundo o qual admitir que qualquer inconstitucionalidade constitui motivo suficiente para ensejar a relativização da coisa julgada permite uma absoluta vulnerabilidade do instituto, uma vez que não leva em consideração a ponderação entre o valor segurança e o valor transgredido em cada caso concreto. $\mathrm{O}$ autor caracteriza esta postura como puramente dogmática, sob o argumento de que ela consiste, tão somente, em comparar hierarquicamente as leis e as decisões com a Constituição Federal.

Desse modo, Cândido Rangel Dinamarco defende que, em princípio, ainda que a decisão seja inconstitucional, a coisa julgada deve prevalecer, porque ela também é uma garantia constitucional. Percebe-se, portanto, que o autor recorre à técnica da ponderação e ao princípio da proporcionalidade, a fim de admitir a relativização da coisa julgada inconstitucional somente se o valor transgredido na decisão judicial for de nível mais elevado que a segurança jurídica.

\subsection{Críticas à Teoria da Relativização}

Os doutrinadores que não admitem a relativização da coisa julgada inconstitucional defendem que o referido instituto processual é uma garantia imprescindível em um

${ }^{23}$ DINAMARCO, Cândido Rangel, op. cit., p. 241. 
Estado Democrático de Direito, tutelando a segurança das relações jurídicas e a própria inafastabilidade da jurisdição. ${ }^{24}$ Ademais, sustentam que a justiça é conceito subjetivo, de modo que, sob o argumento de extrema injustiça inconstitucional, as decisões tornar-se-iam suscetíveis a sucessivas relativizações, eternizando-se as lides e aniquilando o próprio instituto da coisa julgada. ${ }^{25}$

Luiz Guilherme Marinoni adverte acerca da ausência de garantia de que a segunda decisão - proferida em substituição à primeira, que teve a sua coisa julgada relativizada - estará em conformidade com as regras do ordenamento jurídico e com os ditames da justiça. ${ }^{26}$ Outros doutrinadores, conquanto não sejam totalmente desfavoráveis à relativização, criticam certas hipóteses e certos argumentos apresentados para justificá-la, afirmando que eles constituem excepcionalidades no ordenamento jurídico. ${ }^{27}$

Embora seja inegável a relevância do movimento de relativização da coisa julgada, tendo em vista que ele se destina à concretização do ideal do justo, as diversas críticas

${ }^{24}$ MARINONI, Luiz Guilherme. Relativizar a coisa julgada material? Revista dos Tribunais, São Paulo, ano 93, v. 830, p. 55-73, dez. 2004; GÓES, Gisele Santos Fernandes, op. cit., p. 254.

${ }^{25}$ DIDIER JÚNIOR, Fredie; BRAGA, Paula Sarno; OLIVEIRA, Rafael. Curso de Direito Processual Civil. 4. ed. Savador: Jus Podivm, 2009. p. 443; MARINONI, Luiz Guilherme, op. cit., p. 71; GÓES, Gisele Santos Fernandes, op. cit., p. 254 et seq.

${ }^{26}$ MARINONI, Luiz Guilherme, op. cit., p. 58.

27 "Reconheça-se desde logo que os exemplos são, por assim dizer (sem ironia), pitorescos. Outra questão é saber se existe alguma probabilidade de que hipóteses tão esdrúxulas se concretizem no mundo real." MOREIRA, José Carlos Barbosa, op. cit, p. 250. Em conformidade é a lição de Ovídio A. Baptista da Silva, o qual afirma que relativizar a coisa julgada sob o fundamento de transgressão a princípio é questioná-la com base em premissa impalpável e difícil de ser visualizada, pois princípios constituem normas abertas que obedecem a uma escala de otimização. SILVA, Ovídio A. Baptista da. Coisa Julgada Relativa? Revista Jurídica, São Paulo, n. 316, p. 7-18, fev. 2004. 
que lhe são direcionadas demonstram que é preciso agir com parcimônia. Desse modo, a pretexto de se concretizar um ideal de justiça, não se pode colocar em risco os instrumentos garantidores do devido processo legal. Em conformidade com referido pensamento, José Carlos Barbosa Moreira tece a seguinte advertência: "Há, porém, um momento em que à preocupação de fazer justiça se sobrepõe a de não deixar que o litígio se eternize." 28

\section{Do Vício da Inconstitucionalidade}

\subsection{Análise do Vício da Inconstitucionalidade sob a Ótica da Teoria dos Atos Jurídicos}

Há diferentes apontamentos acerca do vício da inconstitucionalidade, divergindo a doutrina se o mesmo atinge o plano da existência ${ }^{29}$, da validade ${ }^{30}$ ou da eficácia ${ }^{31}$ das sentenças por ele contaminadas. Por serem os pronunciamentos judiciais categoria dos atos jurídicos, a fim de desvendar em qual plano situa-se o vício da inconstitucionalidade, valemo-nos da teoria geral dos atos jurídicos. ${ }^{32}$

${ }^{28}$ MOREIRA, José Carlos Barbosa, op. cit., p. 243.

${ }^{29}$ WAMBIER, Teresa Arruda Alvim; MEDINA, José Miguel Garcia. O Dogma da Coisa Julgada: hipóteses de relativização. São Paulo: Editora Revista dos Tribunais, 2003. p. 354-358.

30 THEODORO JÚNIOR, Humberto; FARIA, Juliana Cordeiro de, op. cit, p. 89-90.

${ }^{31}$ DINAMARCO, Cândido Rangel, op. cit., p. 248.

${ }^{32}$ Nesse ponto, torna-se relevante a seguinte observação, formulada pelo professor Adroaldo F. Fabrício, no que tange à teoria das nulidades: "Quando se trata da validade de atos processuais, e em particular da sentença, o esquema classificatório dos vícios fixado pela doutrina tradicional, se aproveitável, tem de ser tomado com cautela, tendo-se em cuidadosa linha de conta a especificidade daqueles atos e sobretudo a eficácia sanatória peculiaríssima da coisa julgada." 
Desse modo, entendemos que a decisão judicial, mesmo quando inconstitucional, é existente, pois contém todos os requisitos tecnicamente indispensáveis à sua finalidade prática. Assim, para o presente artigo, a tese que se revela mais adequada é a que situa o vício da inconstitucionalidade no plano da validade da decisão judicial, tornando-a nula, assim como ocorre com os atos legislativos inconstitucionais. Em conformidade, é a lição de Luís Roberto Barroso:

A inconstitucionalidade, portanto, constitui vício aferido no plano da validade. Reconhecida a invalidade, tal fato se projeta para o plano seguinte, que é o da eficácia: norma inconstitucional não deve ser aplicada. ${ }^{33}$

Nos termos dos ensinamentos supracitados, conclui-se que a decisão judicial eivada do vício da inconstitucionalidade é nula e que o reconhecimento de tal invalidade projeta-se para o plano da eficácia, de modo que deverão ser desconstituídos os efeitos produzidos. Frisa-se, nesse ponto, que a decisão judicial, por ter produzido efeitos, deverá ser desconstituída..$^{34}$ Não basta, pois, desconsiderá-la, como têm admitido alguns doutrinadores, que defendem a simples possibilidade de ajuizamento de uma nova ação.

FABRÍCIO, Adroaldo Furtado. Réu revel não citado, querela nullitatis e ação rescisória. Revista de Processo, São Paulo, n. 48, p. 27-44, 1987.

33 BARROSO, Luís Roberto, op. cit., p. 14-15.

34 "[...] o ato processual nulo produz efeitos, se e enquanto o juiz não o desconstituir [...]". ASSIS, Araken de. Coisa Julgada inconstitucional. In: NASCIMENTO, Carlos Valder do (Coord.), op. cit., p. 217. 


\subsection{Vício da Inconstitucionalidade e Eficácia Sanatória Geral da Coisa Julgada}

Um questionamento relevante que permeia a análise do vício da inconstitucionalidade é a possibilidade de ser ele sanado pela eficácia sanatória geral da coisa julgada. Acerca do referido questionamento, esclarecedores são os ensinamentos de Enrico Tullio Liebman, o qual adverte que há vícios maiores e essenciais que sobrevivem à coisa julgada, como o vício da inconstitucionalidade..$^{35}$

Nesse contexto, cumpre relembrar que as nulidades que viciam o processo como um todo, inclusive o pronunciamento judicial, em regra, ou são sanadas por meio da eficácia sanatória da coisa julgada ou transformam-se em hipóteses de rescindibilidade. ${ }^{36}$ Há, contudo, uma hipótese em que o vício não é sanado por meio da eficácia sanatória geral da coisa julgada, tampouco pelo decurso do prazo decadencial de dois anos previsto para o ajuizamento da ação rescisória: é o caso da citação irregular somada à revelia, vício esse que, segundo doutrina e jurisprudência majoritárias, enseja o cabimento da querela nullitatis. ${ }^{37}$

${ }^{35}$ LIEBMAN, Enrico Tullio apud THEODORO JÚNIOR, Humberto; FARIA, Juliana Cordeiro de, op. cit., p. 109.

36 "Com a passagem em julgado, em regra, as nulidades absolutas e relativas, propriamente ditas, ou simples anulabilidades, ou são de todo apagadas ou assumem a feição de mera rescindibilidade". FABRÍCIO, Adroaldo Furtado, op. cit., p. 27-44.

37 "A despeito da disciplina geral, a lei infraconstitucional, que outorga, ou não, a eficácia de coisa julgada a determinados provimentos do juiz, às vezes erige determinado vício essencial, porque ele parece suficientemente grave e relevante, de modo a receber tratamento privilegiado e diferente, à condição de defeito imune a quaisquer preclusões, incluindo a mais expressiva e maior delas: a coisa julgada. Na hipótese do inc. I do art. 741, o vício da citação sobrevive ao trânsito em julgado do título [...] Põe-se de acordo a doutrina que, no art. 741, I, subsiste a vetusta querela nullitatis romana." ASSIS, Araken de, op. cit., p. 218. Nesse mesmo 
Assim, tendo em vista que a eficácia sanatória da coisa julgada não sana determinadas irregularidades que se transformam em hipóteses de rescindibilidade, existindo, ainda, a hipótese de citação irregular, a qual não é sanada nem mesmo com o decurso do prazo da ação rescisória, entendemos que referida eficácia, com maior razão, também não sana o vício da inconstitucionalidade, porquanto este, além de ensejar nulidade absoluta, é um vício de extrema gravidade. Desse modo, entendemos que o vício da inconstitucionalidade deve ser enquadrado na categoria dos denominados "vícios transrescisórios" ${ }^{38}$, uma vez que ele transcende à coisa julgada e ao prazo bienal da ação rescisória.

\section{Instrumentos da Relativização}

\section{1 Instrumentos da Relativização Típica}

No que diz respeito à relativização típica ${ }^{39}$ da coisa julgada inconstitucional, os instrumentos que se destinam a tal propósito são a ação rescisória e a impugnação de sentença inconstitucional previstos nos artigos $475-\mathrm{L}$, parágrafo $1^{\mathrm{o}}$, e 741, parágrafo único, do CPC (Código de Processo Civil).

sentido, é o posicionamento de Adroaldo Furtado Fabrício. FABRÍCIO, Adroaldo Furtado, op. cit., p. 27-44.

${ }^{38}$ De acordo com Tesheiner, transrescisórios são "vícios correspondentes a pressupostos cuja falta autoriza a declaração da inexistência ou ineficácia da sentença, ou a decretação de sua nulidade, ainda que decorrido o prazo para a propositura da ação rescisóra." TESHEINER, José Maria Rosa. Pressupostos processuais e nulidades no processo civil. São Paulo: Saraiva, 2000. p. 283-284.

${ }^{39}$ Conforme já assinalado na introdução, há na doutrina quem estabeleça diferenciação entre as expressões "relativização típica" e "relativização atípica". Assim, a primeira expressão é utilizada tão somente para os casos em que a coisa julgada pode ser relativizada com base em instrumentos legalmente previstos. Já a segunda, é utilizada para se referir a todas as hipóteses não tipificadas no ordenamento jurídico brasileiro. 
A ação rescisória é uma ação autônoma de impugnação da decisão de mérito, que deve ser ajuizada dentro do prazo decadencial de dois anos contados a partir do trânsito em julgado, desde que verificada alguma hipótese prevista no artigo 485, do CPC. ${ }^{40}$ As hipóteses de rescindibilidade previstas nos nove incisos do artigo 485, do CPC, constituem um rol taxativo, não se admitindo interpretação extensiva.

Os artigos 475-L, parágrafo $1^{\circ}$, e 741, parágrafo único, do CPC, disciplinam, respectivamente, a impugnação ao cumprimento de sentença e os embargos à execução contra a Fazenda Pública. Eles possuem redação idêntica e dispõem acerca da inexigibilidade do título judicial fundado em lei ou ato normativo declarados inconstitucionais pelo STF, ou fundado em aplicação ou interpretação da lei ou ato normativo tidas pelo STF como incompatíveis com a Constituição Federal. Tais dispositivos são exemplos expressos do início do movimento de relativização da coisa julgada.

Convém registrar, no entanto, que na hipótese dos artigos 475-L, parágrafo $1^{\circ}$, e 741, parágrafo único, os provimentos judiciais permanecerão íntegros. Com efeito, nesses

${ }^{40}$ Excepcionalmente, tem-se admitido o ajuizamento da ação rescisória em face de decisão que não versou sobre matéria de mérito, desde que sejam juridicamente impossíveis a propositura de outra demanda idêntica e a interposição de recurso. Nesse sentido, é a lição do professor Bernardo Pimentel, o qual cita como exemplo a hipótese em que o juiz de primeiro grau extingue o processo sem julgamento do mérito, com base no art. 267, V, do CPC. Nesse caso, decorrido in albis o prazo recursal, se o autor constatar que a referida sentença está contaminada com vício arrolado no art. 485, tendo em vista a impossibilidade de se ajuizar nova ação (CPC, 268), a única solução é o ajuizamento de ação rescisória, embora trate-se de sentença terminativa. PIMENTEL SOUZA, Bernardo. Introdução aos recursos cíveis e à ação rescisória. 7. ed. São Paulo: Saraiva, 2010. p. 619. Cumpre ainda ressaltar que o trânsito em julgado da decisão de mérito só ocorre após o último julgamento proferido no processo, ainda que esse último julgamento não tenha versado sobre o mérito da causa. Ibidem, p. 58. 
casos, o juízo de inconstitucionalidade atuará no plano da eficácia, desfazendo a eficácia da coisa julgada de forma retroativa e apagando o efeito executivo da condenação, de forma a tornar inadmissível a execução. ${ }^{41}$

Essa solução jurídica adotada pelo ordenamento é alvo de muitas críticas. Em primeiro lugar, porque referidos dispositivos não preveem a desconstituição dos títulos judiciais inconstitucionais, estabelecendo, tão somente, a sua inexigibilidade. Em segundo lugar, porque os dispositivos não ressalvam a inconstitucionalidade superveniente ao trânsito em julgado, razão pela qual, a exemplo do que ocorre com os incisos I, dos referidos dispositivos, tem-se permitido que a inexigibilidade seja alegada a qualquer momento. ${ }^{42} \mathrm{Em}$ terceiro lugar, porque permitem que um juiz de primeiro grau determine a inexigibilidade de decisão proferida por órgão superior. Em quinto lugar, porque tais dispositivos não abarcam as decisões satisfativas, as quais dispensam futura execução, como ocorre com as decisões declaratórias. ${ }^{43}$

\subsection{Instrumentos da Relativização Atípica}

Entre os doutrinadores que admitem a relativização atípica da coisa julgada, surge a discussão de qual seria o instrumento processual adequado para tal fim. Nesse

\footnotetext{
${ }^{41}$ ASSIS, Araken de, op. cit., p. 221.

42 "A qualquer momento, pronunciada a inconstitucionalidade da lei ou do ato normativo em que se baseou o pronunciamento judicial, desaparecerá a eficácia do art. 467. E isto se verificará ainda que a Corte Constitucional se manifeste após o prazo de dois anos da rescisória (art. 495)." ASSIS, Araken de, op. cit., p. 222.

${ }^{43}$ GOMES, Magno Federici; COHEN, Ricardo Moraes. Relativização da Coisa Julgada: Teorias, Controvérsias, Dilemas e Solução. Revista IOB de Direito Civil e Processual Civil, São Paulo, ano IX, n. 53, p. 83-101, maio/jun. 2008.
} 
sentido, para a maioria deles, a desconstituição da coisa julgada inconstitucional independe de muita formalidade, podendo efetivar-se através de ação rescisória; embargos à execução; exceção de pré-executividade; querela nullitatis; incidentalmente, em uma ação ordinária tendente a reexaminar a mesma relação jurídica; e, até mesmo, de ofício. ${ }^{44}$

Uma crítica consistente direcionada à relativização atípica é exatamente a ausência de parâmetros na definição dos instrumentos viáveis para concretizá-la. Isso porque referidos instrumentos podem gerar uma grave incompatibilidade lógica no sistema: a possibilidade de qualquer juiz ou tribunal desrespeitar a coisa julgada decorrente de decisão proferida por outro órgão judiciário, de igual ou superior hierarquia. ${ }^{45}$

\subsection{Análise sob a Ótica do Ordenamento de Lege Lata}

Alguns doutrinadores defendem que não há que se falar em meios atípicos de relativização, pois o ordenamento jurídico brasileiro de lege lata permite a desconstituição da coisa julgada que acoberta a sentença inconstitucional. Nesse sentido, o doutrinador Fredie Didier defende que o direito positivo brasileiro já solucionou o problema da relativização da coisa julgada inconstitucional de duas maneiras: com a possibilidade de ação rescisória fundamentada na violação literal de lei, prevista no artigo 485, inciso V, do CPC, juntamente

44 THEODORO JÚNIOR, Humberto; FARIA, Juliana Cordeiro de, op. cit., p. 96-97; CÂMARA, Alexandre Freitas, op. cit., p. 196-200.

45 TESHEINER, José Maria Rosa. Relativização da Coisa Julgada. Revista do Ministério Público/RS, Porto Alegre, n. 47, p. 104-114, 2002. 
com a mitigação do rigor da súmula $n^{\circ} 343$ do STF, e com a inexigibilidade do título judicial contrário à Constituição Federal prevista nos artigos 475-L, parágrafo $1^{\circ}$, e 741 , parágrafo único, do CPC. ${ }^{46}$

De acordo com Fredie Didier, a sentença de mérito transitada em julgado que viola a Constituição Federal pode ser desconstituída com fundamento no inciso $\mathrm{V}$, do artigo 485, do CPC, o qual dispõe sobre a hipótese de violação literal à disposição de lei. Cumpre registrar que a acepção do termo lei no referido dispositivo é ampla, abrangendo, inclusive, a Constituição Federal. ${ }^{47}$

$\mathrm{O}$ vocábulo literal inserto no inciso $\mathrm{V}$, do artigo 485, revela a exigência de que a afronta deve ser tamanha que contrarie a lei em sua literalidade, ou seja, se o texto legal der ensejo a mais de uma interpretação, não é possível desconstituir o julgado com fundamento em qualquer uma das interpretações plausíveis. Essa é a orientação da súmula n. 343 do STF: "Não cabe ação rescisória por ofensa a literal disposição de lei, quando a decisão rescindenda se tiver baseado em texto legal de interpretação controvertida nos tribunais."

No entanto, no que tange à violação a preceito constitucional, o próprio STF tem decidido ser inaplicável o referido enunciado sumular. ${ }^{48}$ Prevalece, assim, o entendimento consubstanciado na súmula n. 63 do TRF (Tribunal Regional Federal) da 4⿳亠丷a Região: "Não é aplicável a Súmula 343 do STF nas ações rescisórias versando matéria constitucional". Desse

\footnotetext{
${ }^{46}$ DIDIER JÚNIOR, Fredie; BRAGA, Paula Sarno; OLIVEIRA, Rafael, op. cit., p. 443.

47 PIMENTEL SOUZA, Bernardo, op. cit., p. 628-629.

${ }^{48}$ BRASIL. Supremo Tribunal Federal. Ag. Reg. no RE 567.765/SP. Recorrente: Marcos A. Camilo. Recorrido: Banco Bradesco S/A. Relator: Rosa Weber. Brasília, 16 de abril de 2013.
} 
modo, tendo em vista que, não raras vezes, o mesmo dispositivo constitucional dá ensejo a interpretações variadas, ainda assim será possível o ajuizamento de ação rescisória com base no inciso $\mathrm{V}$, do artigo 485, do CPC.

Ao se mitigar a aplicabilidade da súmula n. 343 no que tange às matérias constitucionais, afasta-se o requisito da ofensa literal, instituindo-se, na verdade, uma cláusula geral de revisão da coisa julgada inconstitucional. Portanto, nota-se que a conjugação do inciso $\mathrm{V}$, do art. 485, do CPC, com a mitigação da súmula 343 do STF, efetivamente cria uma hipótese de rescisão de toda e qualquer decisão de mérito transitada em julgado que viola diretamente a Constituição Federal.

\subsection{Proposta de Lege Ferenda}

Não obstante tenha o ordenamento jurídico brasileiro criado uma cláusula geral de revisão das sentenças inconstitucionais transitadas em julgado que violam diretamente a Constituição Federal, o problema persiste após o transcurso do prazo de dois anos, ou seja, em relação à coisa soberanamente julgada. ${ }^{49}$

Ademais, em relação às decisões que violam indiretamente a Constituição Federal, previstas nos artigos 475-L, parágrafo $1 \%$, e 741, parágrafo único, embora o ordenamento jurídico tenha criado uma forma de relativização, permitindo a inexigibilidade do título judicial, essa solução, conforme já demonstrado, é alvo de muitas críticas.

${ }^{49}$ A expressão "Coisa soberanamente julgada" refere-se à decisão transitada em julgado que não pode mais ser revista por meio da ação rescisória, por já ter transcorrido o prazo decadencial de dois anos. 
Assim, com o intuito de uniformizar o regramento legal acerca da sentença inconstitucional e dirimir as incongruências que permeiam o ordenamento atual, o presente trabalho propõe uma alteração legislativa no inciso $\mathrm{V}$, do artigo 485, do CPC, de modo que o mesmo, que já abrange as hipóteses de violação direta à Constituição Federal, passe a alcançar as hipóteses de violação indireta. Dessa forma, não haveria razão para a subsistência dos artigos 475-L, parágrafo $1^{\circ}$, e 741, parágrafo único, no ordenamento jurídico.

Além de concentrar-se no inciso V, do artigo 485, do $\mathrm{CPC}$, as hipóteses de violação direta e indireta à Constituição Federal, propõe-se que se estabeleça, em conformidade com os ensinamentos de Cândido Rangel Dinamarco, a necessidade de ponderação diante do caso concreto, a qual deverá ser efetivada pelo tribunal competente no momento de apreciação da ação rescisória. Somente se o valor constitucional violado for superior ao valor segurança jurídica é que será permitida a desconstituição da coisa julgada.

Tendo em vista que no caso de violação indireta à Constituição Federal já se tem permitido a alegação de inexigibilidade do título a qualquer momento ${ }^{50}$, com muito mais razão deverá ser abolida a exigência de prazo para a hipótese de violação direta. Tal fato, somado à gravidade do vício da inconstitucionalidade e à inexistência de prazo para o reconhecimento da inconstitucionalidade dos atos legislativos, leva-nos a defender a abolição do prazo decadencial de dois anos em todos os casos de violação à Constituição Federal. Ressalta-se, no entanto, que a abolição do prazo abrangerá

50 "Ressalta-se que o uso da ação autônoma não se vincula à observância do prazo dos embargos (art. 738). É lícito ao vencido empregá-lo após o desaparecimento da oportunidade para embargar." ASSIS, Araken de, op. cit., p. 226. 
apenas as hipóteses de inconstitucionalidade, persistindo a necessidade de se respeitar o biênio nos casos de mera ilegalidade.

A abolição do prazo decadencial, embora, em um primeiro momento, seja um indicativo de violação à segurança jurídica, podendo ocasionar o aumento do número de demandas rescisórias, constitui uma mudança necessária para se evitar a própria desconsideração da coisa julgada.

Nesse sentido, faz-se necessário registrar que persistirá a necessidade de ajuizamento da ação rescisória, de modo que não será possível desconstituir a coisa julgada por qualquer meio processual. Ademais, sendo a referida ação de competência originária dos tribunais, afasta-se a possibilidade de violação à hierarquia das decisões judiciais, não sendo possível que um magistrado possa desconstituir coisa julgada de decisão proferida por juízo de instância superior ou reconhecer a inexigibilidade da referida decisão.

Por derradeiro, ressaltamos que o próprio regramento legal da ação rescisória prevê mecanismos capazes de evitar o ajuizamento de ações manifestamente inadmissíveis e improcedentes, como a necessidade de depósito equivalente a $5 \%$ (cinco por cento) do valor da causa, conforme prevê o artigo 488 , II, do CPC. ${ }^{51}$

${ }^{51}$ Os doutrinadores Alexandre Freitas Câmara e Sérgio Gilberto Porto também formularam, em relação ao presente tema, propostas de lege ferenda que englobam a revisão das hipóteses de cabimento da ação rescisória e do prazo decadencial de dois anos. CÂMARA, Alexandre Freitas, op. cit., p. 201; PORTO, Sérgio Gilberto. Cidadania processual e relativização da coisa julgada. Revista Síntese de Direito Civil e Processual Civil, Porto Alegre, v. 4, n. 21, p. 5-13, jan./fev. 2003. 


\section{Considerações Finais}

O fato de ser a coisa julgada um direito fundamental e, por conseguinte, cláusula pétrea, não significa que ela seja absoluta e imune a quaisquer revisões. Por outro lado, é preciso parcimônia em relação ao desejo de mudar, sob pena de se aniquilar garantias fundamentais ao Estado Democrático de Direito.

O presente artigo prestigiou a doutrina que enquadra o vício da inconstitucionalidade no plano da validade da decisão e defendeu o seu enquadramento na categoria dos vícios transrescisórios, sendo, pois, necessário encontrar um instrumento hábil para desconstituir a coisa julgada inconstitucional dele resultante.

Para isso, antes de se apresentar qualquer proposta de lege ferenda, procurou-se buscar uma solução nos instrumentos legalmente previstos para a revisão da coisa julgada. Desse modo, verificou-se que o ordenamento jurídico brasileiro, de lege lata, permite a revisão de sentenças inconstitucionais transitadas em julgado.

No que diz respeito à decisão que viola indiretamente a Constituição Federal, o CPC expressamente criou uma hipótese de relativização da coisa julgada, conforme vislumbra-se nos artigos 475 -L, parágrafo $1^{\circ}$, e 741 , parágrafo único. No que diz respeito à violação direta da Constituição Federal, nota-se que a conjugação do artigo $485, \mathrm{~V}$, do CPC, com o afastamento do enunciado n. 343 da súmula do STF, permite a desconstituição da decisão acobertada pela coisa julgada inconstitucional. 
No entanto, foi constatado que o ordenamento jurídico de lege lata incorre em diversas incongruências, que são alvos de muitas críticas. Desse modo, a fim de contribuir para o adequado tratamento das sentenças inconstitucionais transitadas em julgado, apresentou-se uma proposta de lege ferenda que prevê algumas alterações no instituto da ação rescisória. Pretende-se, a partir da referida proposta, evitar a perpetuação de injustiças, com a cautela de não se promover mudanças desnecessárias e de garantir a observância do devido processo legal, prestigiando, igualmente, a segurança jurídica.

\section{Referências}

ASSIS, Araken de. Coisa Julgada inconstitucional. In: NASCIMENTO, Carlos Valder do (Coord.). Coisa julgada inconstitucional.

244 4. ed. Rio de Janeiro: América Jurídica, 2003.

BARROSO, Luís Roberto. O controle de constitucionalidade no direito brasileiro. 4. ed. São Paulo: Saraiva, 2009.

CÂMARA, Alexandre Freitas. Relativização da coisa julgada material. In: NASCIMENTO, Carlos Valder do (Coord.). Coisa julgada inconstitucional. 4. ed. Rio de Janeiro: América Jurídica, 2003.

DELGADO, José Augusto. Efeitos da coisa julgada e os princípios constitucionais. In: NASCIMENTO, Carlos Valder do (Coord.). Coisa julgada inconstitucional. 4. ed. Rio de Janeiro: América Jurídica, 2003.

DIAS, Maria Berenice. Manual de Direitos das Famílias. 5. ed. São Paulo: Editora Revista dos Tribunais, 2009.

DIDIER JÚNIOR, Fredie; BRAGA, Paula Sarno; OLIVEIRA, Rafael. Curso de Direito Processual Civil. 4. ed. Savador: Jus Podivm, 2009.

DINAMARCO, Cândido Rangel. A Nova Era do Processo Civil. São Paulo: Malheiros, 2003.

FABRÍCIO, Adroaldo Furtado. Réu revel não citado, querela nullitatis e ação rescisória. Revista de Processo, São Paulo, n. 48, p. 27-44, 1987. 
GÓES, Gisele Santos Fernandes. A "Relativização" da Coisa Julgada: exame crítico (exposição de um ponto de vista contrário). Revista de Processo, São Paulo, ano 31, n. 135, p. 249-265, maio 2006.

GOMES, Magno Federici; COHEN, Ricardo Moraes. Relativização da Coisa Julgada: Teorias, Controvérsias, Dilemas e Solução. Revista IOB de Direito Civil e Processual Civil, São Paulo, ano IX, n. 53, p. 83-101, maio/jun. 2008.

KELSEN, Hans. Teoria Pura do Direito. 6. ed. São Paulo: Martins Fontes, 1998.

LIMA, Paulo Roberto de Oliveira. Contribuição à teoria da coisa julgada. São Paulo: RT, 1997.

MARINONI, Luiz Guilherme. Relativizar a coisa julgada material? Revista dos Tribunais. São Paulo, ano 93, v. 830, p. 55-73, dez. 2004.

MITIDIERO, Daniel. Colaboração no processo civil: pressupostos sociais, lógicos e éticos. 2. ed. São Paulo: Editora Revista dos Tribunais, 2011.

MOREIRA, José Carlos Barbosa. Temas de direito processual civil (nona série). São Paulo: Saraiva, 2007.

OTERO, Paulo. Ensaio sobre o caso julgado inconstitucional. Lisboa: Lex, 1993.

PIMENTEL SOUZA, Bernardo. Introdução aos recursos cíveis e à ação rescisória. 7. ed. São Paulo: Saraiva, 2010.

PORTO, Sérgio Gilberto. Cidadania processual e relativização da coisa julgada. Revista Síntese de Direito Civil e Processual Civil, Porto Alegre, v. 4, n. 21, p. 5-13, jan./fev. 2003.

SILVA, Ovídio A. Baptista da. Coisa Julgada Relativa? Revista Jurídica, São Paulo, n. 316, p. 7-18, fev. 2004.

TESHEINER, José Maria Rosa. Pressupostos processuais e nulidades no processo civil. São Paulo: Saraiva, 2000.

. Relativização da Coisa Julgada. Revista do Ministério Públicol RS, Porto Alegre, n. 47, p. 104-114, 2002.

THEODORO JÚNIOR, Humberto; FARIA, Juliana Cordeiro de. A coisa julgada inconstitucional e os instrumentos processuais para o 
Relativização da Coisa Julgada Inconstitucional...

seu controle. In: NASCIMENTO, Carlos Valder do (Coord.). Coisa julgada inconstitucional. 4. ed. Rio de Janeiro: América Jurídica, 2003. WAMBIER, Teresa Arruda Alvim; MEDINA, José Miguel Garcia. O Dogma da Coisa Julgada: Hipóteses de Relativização. São Paulo: Editora Revista dos Tribunais, 2003.

Submissão: 08/06/2013

Aceito para Publicação: 31/07/2013 


\section{A Oralidade (e a Escrita) no Novo Código de Processo Civil Brasileiro Orality (and Writing) in the New Brazilian Civil Procedure Code}

Oscar Valente Cardoso*

Resumo: $\mathrm{O}$ artigo trata da oralidade no processo civil brasileiro, sob as perspectivas histórica e normativa, com o objetivo de examinar a regulamentação atual pelo Código de Processo Civil e o tratamento conferido pelo Anteprojeto do novo Código. Aborda aspectos conceituais e classificações da oralidade e sua evolução histórica, no Direito Romano, no Ius Commune da Idade Média e na Idade Moderna, especialmente em Portugal e no Brasil. No Brasil, examina-se a regulamentação da oralidade no Regulamento 737 e nos Códigos de Processo Civil de 1939 e 1973, para, ao fim, verificar a existência (ou não) de mudanças no projeto da nova codificação processual.

Palavras-chave: Oralidade. Direito Romano. Idade Média. Ius Commune. Código de Processo Civil.

Abstract: This article deals with orality in Brazilian civil procedure, under normative and historical perspectives, in order to examine the current regulation by the Brazilian Civil Procedure Code and the treatment given by the new Code draft. It addresses conceptual aspects, and orality classifications and its historical evolution, in Roman Law, Middle Age Ius Commune and Modern Age, especially in Portugal and Brazil. In Brazil, it examines orality legal regulation, in Regulation 737, and in 1939 and 1973 Civil Procedure Code, in order to, finally, determine the existence (or not) of changes in the new Code draft.

* Universidade Federal do Rio Grande do Sul. 
Keywords: Orality. Roman Law. Middle Age. Ius Commune. Civil Procedure Code.

\section{Introdução}

Por ser anterior ao aparecimento da escrita, o processo surgiu com feitio oral e gestual. Porém, gradativamente, a oralidade foi perdendo espaço para a forma escrita, o que causou um afastamento entre os sujeitos do processo: não é incomum que, do início ao fim do andamento processual, as partes sequer tenham contato direto entre si e com o julgador.

Busca-se, neste artigo, analisar historicamente o papel da oralidade no processo civil, para, ao final, examiná-la no processo brasileiro.

Para esse fim, será analisada a delimitação conceitual da oralidade, seguida de sua evolução histórica (no Direito Romano, na Europa e no Brasil), para, na sequência, examinar as normas do projeto do novo CPC pátrio.

\section{Aspectos Conceituais}

Em primeiro lugar, e independentemente da incerteza legal e doutrinária acerca de sua natureza jurídica (regra, princípio ou critério), a oralidade é uma forma de realização do ato processual, ou seja, designa o modo verbal da prática dos atos (critério).

Vista como um princípio, é norma informadora de outras regras e (sub)princípios, como a identidade física do juiz, a imediatidade, a concentração dos atos (na audiência, 
em regra) e a irrecorribilidade imediata das decisões interlocutórias. Motiva a intervenção do juiz na produção da prova e exige a prática oral dos atos processuais (excepcionalmente à forma escrita). Não busca somente a celeridade e a economia processual, mas também a participação ativa e o contato direto das partes (e das provas por ela produzidas) com o julgador.

Attilio Nicora salienta que a oralidade não se confunde com a oratória, pois não indica apenas a prática de atos orais no processo, e trata-se de um "termo infeliz", por não conseguir explicar de forma clara o conceito jurídico que representa (NICORA, 1977, p. 338). Para José Frederico Marques, a oralidade não se resume a um princípio, mas é um sistema ou procedimento oral, formado por princípios interligados: a concentração (que reduz a prática dos atos processuais, concentrando-os em um, ou em poucos atos) ${ }^{1}$, a imediação (ou imediatidade, que determina o contato direto do juiz com as partes e as provas) ${ }^{2}$ e a identidade física do juiz (quem instrui o processo deve julgá-lo) (MARQUES, 1997, p. 499-501). Daniel Mitidiero e Carlos Alberto Alvaro de Oliveira tratam a oralidade como um princípio otimizador da eficiência do processo (OLIVEIRA; MITIDIERO, 2010, p. 82-84.). Mauro Cappelletti relaciona oralidade à prova, e afirma que consiste na "[...] criação de um ordenamento processual idôneo a propiciar uma possibilidade efetiva da livre valoração da prova testemunhal lato sensu, com a correspondente utilização

\footnotetext{
1 Exemplificando, na audiência, há a prática de diversos atos em um só, como a oitiva das partes, das testemunhas, dos peritos e assistentes técnicos, exibição de documentos, sustentações orais, prolação de sentença e interposição de recursos, entre outros (arts. 450/457 do CPC).

2 Nesse sentido é o art. 446, II, do CPC brasileiro em vigor.
} 
ampla da prova indiciária" (CAPPELLETTI, 1962, p. 281). Jefferson Guedes utiliza a expressão "princípio da oralidade" para designar odos os princípios e subprincípios derivados daquele: "[...] a) oralidade aparece em sentido estrito, como realização verbal de atos, ou em sentido amplo, como sinônimo de princípio da oralidade; b) processo oral e procedimento oral servem para denominar a gama toda de procedimentos (e, por conseguinte, de processos) informados tanto pela oralidade em sentido estrito como pela oralidade em sentido amplo" (GUEDES, 2003, p. 171).

Portanto, a oralidade tem um significado estrito de característica do processo (prática oral de atos) e um sentido amplo de princípio informador e otimizador do processo (que abrange outras regras e princípios além da concretização verbal dos atos processuais).

Chiovenda esclarece que o processo oral exige que o juiz que o sentencia seja o mesmo que colhe os elementos de sua convicção, ou seja, que interroga as partes, ouve as testemunhas, questiona os peritos, enfim, examina com seus próprios olhos os objetos e locais controversos. Portanto, é necessário observar o princípio da identidade física do juiz, para que o mesmo magistrado atue do início ao fim, que as atividades processuais se desenvolvam sem interrupção em um curto lapso temporal (com a resolução dos incidentes em audiência), que o contato entre as partes e o juiz seja imediato e que predomine a voz (e não a escrita) como meio de comunicação. Em suma, oralidade é uma expressão que designa um conjunto de princípios interdependentes, e não apenas o modo de realização dos atos processuais (CHIOVENDA, 1949, p. 363-364). 
Acrescenta-se aos conceitos citados que $a$ oralidade não importa na compulsoriedade da prática exclusiva de atos orais. Há quem defenda que sequer é necessária uma prevalência numérica ou proporcional dos atos orais em relação aos escritos ${ }^{3}$, mas sim que ocorra uma primazia de critério na orientação do sistema processual ${ }^{4}$. Ademais, não exige a prática dos atos processuais exclusivamente pelo juiz, mas principalmente o contato direto deste com as partes, o que pode abranger a permissão, para que elas questionem diretamente as testemunhas ${ }^{5}$. Também não é necessariamente ligada aos poderes do juiz; por exemplo, o processo inglês tradicional é oral, mas não confere poderes relevantes para o juiz.

A oralidade abrange outros subprincípios, listados por Chiovenda: (a) o predomínio (e não a exclusividade) da palavra como meio de expressão, admitindo-se o uso da escritura na preparação e na documentação; não basta a oitiva das partes e testemunhas, seguida por debates orais em audiência, para caracterizar um processo como oral, mas sim quando forem orais todos os atos que demandam a valoração de uma declaração; de outra parte, a prática de atos escritos não é incompatível com a oralidade, pois a escrita é usada para perpetuar o pensamento e possui dupla função:

3 Attilio Nicora afirma que é instintiva a relação com a prevalência dos atos orais sobre os escritos como uma característica inerente à oralidade, o que, reitera-se, consiste em uma confusão da oralidade com a oratória (NICORA, 1977, p. 338). Com o mesmo entendimento: MORATO, 1938, p. 12.

4 Com esse entendimento: OLIVEIRA; MITIDIERO, 2010, p. 82. Na Exposição de Motivos do CPC brasileiro de 1939, o Ministro Francisco Campos destacou que "[...] no processo chamado oral, a escrita representa uma grande função. $O$ processo oral funda-se em uma larga base escrita. Nele a escrita continua a representar o seu papel próprio, específico e indispensável".

5 Desenvolvendo o assunto, a partir de normas do Código de Processo Penal: CARDOSO, 2009, p. 83-91. 
prepara o exame da causa (por meio da petição inicial e da resposta do réu, e eventuais réplica e tréplica, que delimitam a demanda) e documenta tudo o que for importante para o processo (especialmente durante a realização da audiência, a fim de auxiliar o juiz a proferir a sentença e permitir que as instâncias superiores tenham acesso aos atos praticados) ${ }^{6}$; (b) a imediação (ou imediatidade) da relação entre o julgador e as pessoas cujas declarações ele deve valorar: o contato direito em audiência do juiz com partes, testemunhas, peritos etc., é imprescindível para a valoração da prova e a formação do convencimento $^{7}$; (c) a identidade física do juiz: decorre dos dois princípios anteriores e considera que só o magistrado que acompanhou o desenvolvimento e a instrução do processo e, principalmente, que participou da audiência, seja o mesmo que irá prolatar a sentença, pois suas impressões, convicções e reflexões sobre a prova diretamente obtida ou presenciada não se transferem para outro julgador ${ }^{8}$; (d) a concentração da análise da causa a um período único (debates) concretizado em uma audiência (ou em poucas audiências entre datas próximas): busca a aplicação da identidade física do juiz, que as provas sejam devidamente valoradas e o processo julgado em um curto espaço temporal, para que o juiz tenha

6 Francisco Morato desenvolve a mesma ideia e afirma que "[...] a palavra é necessária à comunicação, o escrito é necessário à documentação das decisões das partes" (MORATO, 1938, p. 14).

7 A imediação "[...] consiste em fazer o juiz assistir à produção das provas donde tirar sua convicção, isto é, entrar em relações diretas com as testemunhas, peritos e objetos do juízo, de modo a colher de tudo uma impressão imediata e pessoal; [...] só no procedimento oral pode ser plena e eficazmente aplicado" (MORATO, 1938, p. 14).

8 Chiovenda afirma que isso é dispensável e indiferente no processo escrito, como se o processo fosse um quadro, uma estátua ou edifício que pudesse ser projetado por uma pessoa e concluído por outra, ao invés de ser fruto de uma cadeia ordenada de pensamentos (CHIOVENDA, 1969, p. 255). 
lembrança dos atos praticados e suas impressões sobre eles no momento da sentença; (e) e a irrecorribilidade imediata (ou "inapelabilidade") das decisões interlocutórias: auxilia na concentração da causa e evita incidentes dilatórios, pois a oralidade e a concentração não são eficazes caso se permita a impugnação de incidentes de forma separada do mérito (CHIOVENDA, 1969, p. 251-257).

Logo, reitera-se, a preeminência de atos orais sobre os escritos é apenas uma entre as várias características da oralidade.

\section{Antecedentes Históricos: Processo Romano, Direito Comum e Processo Civil Moderno}

Historicamente, o processo civil surgiu sob a forma oral e a escritura não acompanhou o surgimento da escrita, ou seja, mesmo com a criação e o desenvolvimento da grafia, a maior parte dos povos manteve o processo oral por um longo período. $\mathrm{O}$ processo escrito desenvolveu-se somente com a popularização do papel, que possibilitou o uso mais amplo e menos dispendioso de documentos e de manifestações escritas (GUEDES, 2003, p. 18).

Assim, o processo pré-romano era oral, como, por exemplo, entre os gregos, maias, pérsias e sumérios ${ }^{9}$. Uma

9 O Código de Hammurabi, de aproximadamente 1.700 a.C., possuía regras que demonstravam a existência de um processo exclusivamente oral, por meio de debates e a oitiva de testemunhas, como, "9. Se alguém perder algo e encontrar este objeto na posse de outro: se a pessoa em cuja posse estiver o objeto disser 'um mercador vendeu isto para mim, eu paguei por este objeto na frente de testemunhas' e se o proprietário disser 'eu trarei testemunhas para que conhecem minha propriedade', então o comprador deverá trazer o mercador de quem comprou o objeto e as testemunhas que o viram fazer isto, e o proprietário deverá 
das exceções era o Egito, cujo processo continha uma fase inicial escrita, mas desenvolveu-se oralmente ${ }^{10}$.

\subsection{Direito Romano}

No Direito Romano, os processos das legis actiones, per formulas e cognitio, progressivamente sucederam-se no tempo, após períodos de existência comum. Estima-se que as legis actiones tenham surgido no século VIII a.C., o processo per formulas teve início (formalmente) no século II a.C., e a cognitio despontou no século I a.C. ${ }^{11}$.

No período das legis actiones, o processo era marcado pela oralidade (todo o rito se dava por meio de fórmulas orais, e mais tarde escritas no processo per formulas) ${ }^{12}$, mas acompanhada por um formalismo oral e (inicialmente) também gestual. $\mathrm{O}$ formalismo relaciona-se com outra característica, que é a tipicidade: as legis actiones eram modos formais de agir, correspondentes a tipos. Ou melhor, a legis actio possuía uma dupla tipicidade, externa e interna: as situações jurídicas eram tuteladas apenas se o costume, a interpretação, a Lei

trazer testemunhas que possam identificar sua propriedade. O juiz deve examinar os testemunhos dos dois lados, inclusive o das testemunhas. Se o mercador for considerado pelas provas ser um ladrão, ele deverá ser condenado à morte. $\mathrm{O}$ dono do artigo perdido recebe então sua propriedade e aquele que a comprou recebe o dinheiro pago por ela das posses do mercador".

10 Sobre as origens orais do processo civil: GUEDES, 2003, p. 18.

${ }^{11}$ Nesse sentido, Azevedo e Tucci afirmam que as legis actiones existem desde a fundação de Roma em 754 a.C. e perdurou até o fim da República, que o processo per formulas foi instituído pela Lex Aebutia, entre 149 e 126 a.C. (e posteriormente oficializado pela Lex Julia privatorum, de 17 a.C.), e a extraordinaria cognitio surgiu juntamente com o Principado em 27 a.C., perdurando até a derrocada do Império Romano do Ocidente (TUCCI; AZEVEDO, 2001, p. 39).

${ }_{12}$ Max Kaser lista a oralidade, a imediação e a publicidade do julgamento entre os princípios processuais fundamentais do Direito Romano (KASER, 1992, p. 428). 
das XII Tábuas ou outra lei indicassem a correspondente legis $a$ tio $^{13}$. De outro lado, atos não abarcados pelas espécies legais não eram admissíveis e não tinham eficácia.

Chiovenda destaca que o processo romano era predominantemente oral, em face da função processual da prova, conforme demonstram as fontes remanescentes (como as orações de Cícero, documentos processuais e o Corpus Iuris Civilis). Também era concentrado, pois o juiz ouvia as partes, ordenava uma inspeção ocular (que era por ele próprio efetivada no dia seguinte), examinava pessoalmente os lugares e os indícios para, ao final, proferir a sentença (CHIOVENDA, 1949, p. 364); em regra, o processo era concluído em um dia, antes do pôr do sol.

O processo das legis actiones desenvolvia-se oralmente na presença do rei ou do magistrado e, a partir de 367 a.C., do pretor. Suas atribuições resumiam-se ao controle da regularidade formal dos atos, o que abrangia a autorização ou o impedimento do seguimento do processo, quando fosse constatada a existência (ou não) da situação jurídica alegada. Essa atividade era denominada ius dicere ou iurisdictio (noção não totalmente equivalente à noção atual de jurisdição). Iniciava-se com a declaração de uma fórmula oral pelo autor, algumas ações admitiam a provocatio sacramento (aposta verbal), a instrução era oral (oitiva de pessoas e debates) e, por fim, a sentença era proferida verbalmente ${ }^{14}$, que

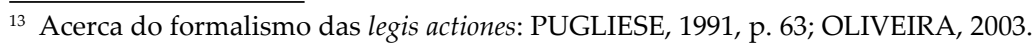
p. 16.

14 Acompanhada da fórmula sacramental "do, dicco, addico", que compreendia respectivamente a admissibilidade da demanda, a declaração do direito aplicável e a aprovação do contrato arbitral firmado pelas partes para a decisão por um juiz privado (durante o período em que o processo foi bipartido nas fases in iure e apud iudicem). 
possibilitava a manus iniectio (oral) e impedia a rediscussão do caso por meio de uma nova legis actio.

O período per formulas trouxe o início da escrita no processo romano, a partir da Lex Aebutia (ou Lex Aebutia de formulis), de 149 a.C. ${ }^{15}$, que eliminou as formas e solenidades orais exigidas pela Lei das XII Tábuas (OLIVEIRA, 2003, p. 18). No processo formulário a exposição da lide pelas partes dava-se sem formas rigorosas e o pretor elaborava uma fórmula escrita, com a nomeação do juiz privado (iudex privatus) e os fatos controversos, para ser instruído e decidido por este. Manteve-se a característica da bipartição do procedimento, com a primeira fase se desenvolvendo perante o pretor e a segunda diante do juiz privado. A etapa do in iure seguia oral: a apresentação do pedido, a in ius vocatio do réu e a sua defesa, até chegar à fórmula, escrita pelo magistrado, com o "programa do processo": a nomeação do iudex e as questões de fato e de direito que seriam objeto da instrução e da decisão, ou seja, uma instrução escrita ao juiz que decidiria a causa ${ }^{16}$. A segunda etapa (apud iudicem) retornava à oralidade, com os debates das partes, a produção de provas e a prolação da sentença em audiência; gradativamente, os documentos ganharam força como meio de prova, até prevalecer sobre as testemunhas (GUEDES, 2003, p. 20). Esse novo procedimento ampliou os poderes dos magistrados,

15 A Lex Aebutia deu início ao período do processo formulário, com procedimento similar ao mencionado, com a exposição da lide sem formas rigorosas e a elaboração da fórmula escrita pelo pretor. Nesse sentido: OLIVEIRA, 2003, p. 18. Acrescenta-se que não se sabe ao certo o teor da Lex Aebutia, havendo opiniões diversas acerca de sua influência sobre a superação das legis actiones pelo processo per formulas (PUGLIESE, 1991, p. 274).

${ }^{16}$ Sobre a fórmula e suas características: KASER, 1992, p. 444-445; PUGLIESE, 1991, p. 284-286. 
ao se desenvolver com base na fórmula escrita em cada caso (OLIVEIRA, 2003, p. 19). Apesar da introdução da escritura e da consequente prática de atos escritos, o processo per formulas manteve-se oral ${ }^{17}$.

No período da cognitio (processo cognitório), juntamente com o fim da bipartição (o processo passou a ter suas etapas realizadas perante juízes funcionários públicos, delegados do Imperador) concretizou-se a primazia da escrita sobre a oralidade. Os atos praticados oralmente eram reduzidos a termo; por outro lado, determinados atos aparentemente orais eram precedidos da forma escrita, como as sentenças, escritas e em seguida publicadas verbalmente ${ }^{18}$. Não se admitia o pedido oral; caso o autor não soubesse ou pudesse escrever, o libellus oralmente manifestado era reduzido a termo pelo tabulário ${ }^{19}$. Em resumo, pedido, resposta e sentença eram escritos, e os atos praticados em audiência reduzidos a termo.

Mesmo assim, nessa época o Imperador Adriano (que governou Roma de 117 a 138 d.C.) publicou um Edito no qual recomendava aos juízes ouvir diretamente as testemunhas, ainda que viessem de uma localidade distante e à custa do Tribunal, a fim de evitar delegações e diligências não realizadas diretamente pelo magistrado. Em suas palavras, alia est auctoritas praesentium testium, alia testimoniorum quae recitari

\footnotetext{
${ }^{17}$ Nas palavras de Carlos Alberto Alvaro de Oliveira, “[...] um processo dominado pelo princípio do livre convencimento do juiz, que pretenda realizar seriamente esse princípio, não pode deixar de ser oral" (OLIVEIRA, 2003, p. 20).

${ }^{18}$ De acordo com: KASER, 1992, p. 471; OLIVEIRA, 2003, p. 22.

${ }^{19}$ Conforme descrito por: FIUZA, 2002, p. 55. Recorda-se que, na época, utilizavam-se tábuas de madeira cobertas com uma camada de cera para a escrita. Desse tempo veio a expressão tábula rasa, ou tábula raspada, que equivalia a uma folha de papel em branco, apagada.
} 
solent, ou seja, um é o valor do testemunho de pessoa presente, $e$ outro é o testemunho apenas lido ${ }^{20}$. Não deveria o juiz conferir o mesmo valor ao depoimento de testemunha que não viu e ouviu diretamente, mas sobre a qual apenas leu seu depoimento escrito. $\mathrm{O}$ Edito de Adriano também previa que, ao julgar, o magistrado não deveria se servir de atas ou termos, porque ele próprio havia ouvido as pessoas: ipsos interrogare soleo. Para Chiovenda, essas três palavras resumem todo o conteúdo da oralidade, resgatado 1.600 anos após, por Mario Pagano, na Itália, Bentham, na Inglaterra, e Mittermaier, na Alemanha, no fim do século XVII e início do século XIX (CHIOVENDA, 1949, p. 364).

Acrescenta-se que a oralidade foi mantida no processo romano mesmo após a introdução da escrita, diante da apresentação oral da contestação e da sentença, além do contato direto entre juiz e partes; e também no processo canônico, oral e público, até que progressivamente os atos do tribunal e das partes foram se restringindo à forma escrita (CHIOVENDA, 1930, p. 219-220).

Em suma, o processo romano surgiu sob a forma oral e foi gradualmente incorporando atos escritos. Contraditoriamente, isso significou um abrandamento do formalismo, pois os atos praticados oralmente (e gestualmente) deveriam observar modos e rituais rígidos, e seu descumprimento obstava o reconhecimento do direito material ${ }^{21}$.

${ }^{20}$ Acerca dessa norma: CHIOVENDA, 1949, p. 364.

${ }^{21}$ Carlos Alberto Alvaro de Oliveira destaca o formalismo que caracterizava as legis actiones, com fórmulas verbais e ritos simbólicos como condições de validade dos atos processuais. Afirma que o formalismo excessivo fazia com que o mero uso de uma única palavra distinta daquela prevista em lei causava a invalidade do ato e podia importar na perda do pedido. Cita como exemplo um caso referido 


\subsection{Direito Comum}

Na Idade Média, com a formação do Ius Commune (Direito Comum) na Europa, o processo consolidou-se como escrito, ganhando importância a figura do notário. A partir do domínio Longobardo (século IV), teve início a inserção das tradições jurídicas germânicas sobre os usos e a prática do Direito Romano. Os costumes dos Longobardos fundiram-se ao direito dos romanos: inicialmente de forma oral e posteriormente transmutados para a forma escrita, que regulavam as relações jurídicas entre os próprios germânicos ${ }^{22}$. Nesse período, prevaleceu o ordo judiciarius, modelo isonômico de busca da descoberta do direito subjetivo por meio do processo, apoiado em pressupostos lógicos e semânticos que definiram os seus principais aspectos; exemplo disso foi o uso da expressão iudicium para denominar o processo, identificando-o com a formação da decisão judicial (MITIDIERO, 2011, p. 89-90).

Chiovenda relembra que o processo germânico era oral, mas foi perdendo esse aspecto após as invasões bárbaras e o início de suas influências recíprocas com o processo romano. Isso ocorreu porque a oralidade germânica existia como consequência do desconhecimento da escrita pelos povos (que tratava de negócios jurídicos na assembleia), ou seja, era diferente da oralidade romana vinculada à prova.

por Gaio, no qual um pleito acerca do corte de árvores foi julgado improcedente porque o autor utilizou a palavra "vinhas" (espécie) ao invés de "árvores" (gênero e a palavra mencionada na Lei das XII Tábuas) (OLIVEIRA, 2003, p. 16-17). Esse exemplo está nas Institutas de Gaio, IV.11 (GAIUS, 2004, p. 183).

22 Sobre a formação e o desenvolvimento do Direito Comum: CAMPITELLI, 1987, p. $79-101$. 
A oralidade no processo germânico incidia em um processo no qual as provas se davam conforme o sistema das ordálias e o juiz decidia de modo vinculado a um suposto juízo divino (que "conduzia" o resultado da ordália), o que posteriormente foi substituído pelo sistema da prova tarifada, que também não conferia liberdade para o julgador atribuir valor às provas. Consequentemente, a oralidade tinha um aspecto formal no processo germânico, que se perdeu automaticamente com o uso da escrita e com a mudança subjetiva do julgador, das assembleias para os juízes (CHIOVENDA, 1949, p. 365).

Este processo escrito que substituiu o processo oral romano foi denominado de processo ordinário romano-canônico ou italiano medieval, e dividia os atos processuais em fases separadas, pois a oitiva das partes e testemunhas era realizada por um juiz diferente daquele que sentenciaria o processo, frequentemente interrompido pelos recursos contra as interlocutionae. Especialmente a partir do século XII (início do renascimento jurídico), ocorreu um aumento da formalidade, não havia oralidade ou a concentração de atos, a oitiva das testemunhas era sigilosa (pois buscava-se evitar influências externas), não havia contato imediato do juiz com as partes, o sistema escrito rígido vedava que as partes se manifestassem oralmente em qualquer ato, e introduziu-se o sistema da prova legal ou tarifada (CAMPITELLI, 1987, p. 94-95; OLIVEIRA, 2003, p. 27).

Em decorrência da limitação dos poderes judiciais, surgiu o princípio da escritura, segundo o qual os atos processuais deveriam ser realizados por escrito ou reduzidos a termo, a fim de que o juiz decidisse exclusivamente com base nos atos escritos (acta scripta). Essa documentação dos atos 
objetivava tutelar as partes contra falsum assertionem iniqui judicis, ou seja, contra iniquidades e falsidades nos motivos das decisões ${ }^{23}$.

\subsection{Direito Processual Moderno}

O paradigma processual da Idade Média manteve-se na maior parte dos países europeus até que, diante da confluência de alguns fatores (renovação do método científico e sua incidência sobre a ciência jurídica, mudanças políticas do final do século XVIII e os estudos sobre o Direito Público), a doutrina processual inseriu-se no novo Direito Público, surgiram os estudos históricos do Direito e, com isso, ganhou força o princípio do livre convencimento do juiz, ao lado do retorno às instituições romanas e à reforma sucessiva dos processos penal e civil de quase todos os países europeus (CHIOVENDA, 1949, p. 365).

No início do século XIX, discutiu-se na Alemanha (parcialmente) invadida a imposição das leis napoleônicas, especialmente o Código de Processo Civil: enquanto o processo comum germânico era complexo e "pesado", o processo francês era simplificado, flexível, mais célere, bem como apoiado na oralidade e na publicidade (CHIOVENDA, 1930, p. 183-184). No final do século XIX, Franz Klein promoveu ampla reforma sobre a legislação processual austríaca, pois via o processo ao mesmo tempo como um relevante

${ }^{23}$ Conforme descrito em: OLIVEIRA, 2003, p. 25. Por exemplo, no século XIV, foi consolidada a romanização do processo francês, com a superação do formalismo germânico pelos princípios romano-canônicos. Entre as inovações ocorridas, Chiovenda cita a substituição da oralidade pela forma escrita (CHIOVENDA, 1930, p. 214-216). 
instrumento público e social e como um mal social (sozial Übel), que deveria ser resolvido do modo mais célere possível. Para atingir esse fim, usavam-se como meios os princípios da oralidade, da publicidade e da livre valoração das provas, o que se exigia a atribuição da direção efetiva (e não somente formal) do processo pelo juiz (OLIVEIRA, 2003, p. 58).

$\mathrm{Na}$ época (final do século XIX e início do XX), Chiovenda considerava que eram orais, na Europa: (a) o processo inglês, que, apesar de um procedimento preliminar escrito, desenvolvia-se na audiência, com a oitiva das partes e das testemunhas; (b) o processo civil francês, a partir do Código de 1806 (que por força das conquistas de Napoleão, de 1799 a 1815, influenciou as principais reformas processuais na Europa continental no século XIX), por ter conferido destaque aos debates orais e na sua influência sobre a formação da convicção do julgador e a sentença ${ }^{24}$; (c) o processo alemão, com o Civilprozessordnung de 1877, apoiado na imediatidade do juiz em relação às partes, testemunhas e peritos, e na irrecorribilidade imediata das decisões interlocutórias (lei posteriormente usada como base na elaboração dos Códigos processuais civis de Japão, China, Dinamarca, Finlândia e Noruega, todos baseados na oralidade ${ }^{25}$; (d) e o processo civil

${ }^{24}$ Acrescenta Chiovenda que o processo francês nunca foi completamente escrito, existindo um nexo entre o processo francês moderno e o processo medieval que existia antes das reformas de Luis XIV, com respeito à oralidade (CHIOVENDA, 1930, p. 219). Essa tradição ainda mantém-se na França, conforme prevê o art. $7^{\text {o }}$ do Código de Processo Civil em vigor no país: "[...] o juiz não pode basear sua decisão em fatos que não estão no debate" ("Le juge ne peut fonder sa décision sur des faits qui ne sont pas dans le débat").

${ }^{25} \mathrm{O}$ autor afirma ainda que a abordagem da oralidade não importa no conflito entre os princípios romanos e germânicos, tendo em vista que comum a ambos, e que o retorno à oralidade no processo alemão moderno é como um retorno ao processo romano (CHIOVENDA, 1930, p. 219-220). 
da maioria dos Cantões suíços, influenciados pelas normas francesas ou alemãs (CHIOVENDA, 1969, p. 224-230).

Contraditoriamente, a superação do procedimento escrito germânico pelo retorno à oralidade romana foi fortemente influenciada pela doutrina da escola histórica alemã, e entre os países que não realizaram essa reforma processual estava, também incongruentemente, a Itália, ou seja, o berço da oralidade. Para encerrar este tópico, recorda-se que Chiovenda buscou fazer do processo moderno um processo oral e vaticinou que "[...] a oralidade acabará sendo reconhecida como uma característica essencial de um processo moderno" (CHIOVENDA, 1949, p. 366).

\section{Surgimento do Processo Civil Brasileiro}

Como consequência direta da colonização portuguesa, o processo civil brasileiro surgiu como um processo português, influenciado pelos elementos romano e germânico (como já se viu no Ius Commune e na formação do processo da modernidade $)^{26}$.

\footnotetext{
${ }^{26}$ Acerca da formação do Direito Processual português e as influências do Direito castelhano sobre ele: TUCCI; AZEVEDO, 2009, p. 21-41. Os dados sobre as Ordenações portuguesas referidos neste texto foram extraídos, em sua maior parte, da obra citada. Na análise de Mitidiero, o processo civil das Ordenações (Afonsinas, Manuelinas e Filipinas) é tipicamente o processo civil do Direito Comum da Idade Média, influenciado pelos elementos romano, canônico e germânico da antiguidade: com soluções de força, adiantamento de execução à cognição, o contraditório e a imparcialidade, o procedimento escrito e secreto, norteado pelos princípios dispositivo e da demanda, com prevalência das partes sobre o juiz, além da divisão do processo em etapas bem delimitadas (para propiciar a aplicação da preclusão) e das normas rígidas acerca das provas (MITIDIERO, 2005, p. 36). Em síntese, processo escrito, juiz distante e desconhecido, com valoração limitada das provas.
} 
As Ordenações portuguesas eram similares aos ordenamentos jurídicos dos países europeus da época, com um processo escrito que mantinha o juiz distante da instrução: as testemunhas eram ouvidas de modo secreto por um inquiridor, na presença de um tabelião que reduzia os depoimentos a termo, e as partes eram cientificadas de seu teor a posteriori, em um momento de abertura e publicação das oitivas ${ }^{27}$. Havia a previsão de embargos das partes antes da abertura das inquirições, versando sobre a ausência da oitiva de testemunhas, ou a indicação de novas, entre outras questões. Na sequência, em virtude do sistema da prova legal, incumbia ao juiz analisar as inquirições e, na existência de apenas "meia prova" em favor do autor (como a apresentação de apenas uma testemunha ou de confissão extrajudicial), deveria oportunizar-lhe a possibilidade de prestar juramento decisório.

264 Citam-se outras regras relativas à prova tarifada: o documento escrito tinha prevalência sobre a prova testemunhal; era necessária a escritura pública como prova de negócios jurídicos sobre bens móveis valorados em mais de 4.000 réis ou imóveis acima de 60.000 réis (OLIVEIRA, 2003, p. 31-32).

Genericamente, nas três Ordenações, incidia o princípio inquisitivo, o processo era dividido em etapas rígidas e autônomas, as partes detinham a iniciativa para dar início e impulsionar o processo, as decisões interlocutórias eram sujeitas a recurso e produziam efeitos de coisa julgada ${ }^{28}$, os prazos eram extensos e prorrogáveis (OLIVEIRA, 2003, p. 32-33).

\footnotetext{
${ }^{27}$ Por exemplo, vide Título XXXXII do Livro III das Ordenações Manuelinas.

${ }^{28}$ Por exemplo, os Títulos LXVII e LXXII do Livro III das Ordenações Afonsinas regulamentavam, respectivamente, as "sentenças interlocutórias" (todas as sentenças ou mandados do juiz anteriores à sentença definitiva) e as apelações cabíveis contra elas.
} 
As Ordenações Afonsinas ${ }^{29}$, concluídas no ano de 1446 (no reinado de Dom Afonso $\mathrm{V}$ ), eram divididas em cinco livros, sendo o Livro III destinado ao processo civil. Apesar de predominantemente escrito, o processo tinha características da oralidade (mesmo com a redução a termo dos atos): o pedido era, em regra, formulado oralmente (e reduzido a termo pelo tabelião ou o escrivão) ${ }^{30}$; adotava-se a imediatidade $^{31}$ e a identidade física do juiz ${ }^{32}$; autor e réu se apresentavam diante do juiz para apresentar provas e nomear as testemunhas a serem ouvidas em audiência ${ }^{33}$; podiam

${ }^{29}$ Surgidas em virtude da insegurança jurídica e dos problemas para a administração da Justiça causados pela elevada quantidade de leis então existentes - algo, pois, que não é um "privilégio" da atualidade.

${ }^{30}$ O Título XXIIII ("Em caso o autor deve formar seu libelo por escrito") previa as situações em que o pedido deve ser apresentado por escrito, e que, em regra, "[...] não seja o autor constrangido a formar sua petição por escrito, e poderá bem dizê-la pela palavra: e o Tabelião, ou Escrivão, que escrever perante o Julgador, que da demanda conhecer, deve escrever essa petição assim posta pela palavra, [...]".

${ }^{31}$ O Título XVII ("Do Autor, que não compareceu ao termo para que citou seu Contendor") determinava o comparecimento de autor e réu perante o juiz, prevendo sanções para a ausência do primeiro (pagamento de custas na primeira ausência e perempção na segunda), que também era qualificada como revelia. Já o Título XXVII ("Do Réu, que foi citado, e não compareceu em Juízo, como se dará contra ele revelia") regulamentava a revelia do réu que não se apresentasse diante do juiz; são peculiares as razões contidas no dispositivo para sancionar a revelia, reproduzindo norma editada por Dom Fernando (que governou Portugal de 1345 a 1383): “O Rei Dom Fernando da Louvada Memória em seu tempo fez Lei, a qual depois confirmou o Rei Dom João, meu Avô de famosa, e esclarecida memória, em esta forma que se segue. 1. Segundo a Doutrina dos Sabedores, e nos mostra a mui certa experiência da coisa, a tardança, e prolongamento daquilo, que os homens desejam, geram continuadamente ódio, e malquerença, e trazem dano [...]".

${ }^{32}$ O Título XXXVIII ("Se o Julgador, ou Voguado é enfermo, ou embargado, que não pode julgar, ou voguar, como se proverá sobre ele") trazia regras de substituição do juiz que, excepcionalmente, não pudesse julgar o processo por ele instruído. Quanto à outra função referida na norma, no português arcaico, utilizavam-se expressões como voguado, vozeiro, arrazoador, procurador e solicitador, para designar a profissão de quem exercia o ius postulandi em juízo.

${ }^{33}$ O Título LXI ("Das testemunhas, que devem ser perguntadas, e quase não") previa o seguinte: "Depois que o julgador assinar termo às partes para darem suas provas, deve-lhes mandar, que nomeem as testemunhas, que entendem a darem o Feito, e se as partes forem presentes, devem-nas nomear logo em essa Audiência, ou em outro dia a mais tardar; [...]". 
apresentar juramento oral ${ }^{34}$; e os embargos à execução eram orais $^{35}$. Logo, o processo civil no Brasil surgiu antes de seu “descobrimento", em 22 de abril de 1500, quando já vigoravam em Portugal as Ordenações Afonsinas ${ }^{36}$.

Em 1521 foram publicadas de forma definitiva as Ordenações Manuelinas, nova consolidação, com as leis editadas após as Ordenações Afonsinas. Daniel Mitidiero destaca que, enquanto as Ordenações Afonsinas efetuaram a sistematização do Direito Português, as Manuelinas promoveram sua divulgação, ou seja, tornaram-no público, especialmente após a criação da imprensa (MITIDIERO, 2005, p. 32). Também eram divididas em cinco livros, com o Livro III destinado ao processo civil, que era igualmente escrito, mas com a oralidade presente desde o pedido inicial, que era apresentado oralmente (reduzido a termo pelo tabelião ou o escrivão) $)^{37}$; foram mantidas a imediatidade ${ }^{38}$, o juramento

${ }^{34} \mathrm{O}$ juramento estava previsto no Título CXVIIII das Ordenações Afonsinas. Trata-se de instituto derivado da provocatio sacramento do Direito Romano, uma aposta na qual cada parte depositava uma quantia em dinheiro (summa sacramenti), posteriormente devolvida à parte vencedora, ficando retido e convertido para o Estado o montante da parte vencida. Essa prática surgiu com o juramento e o dinheiro era usado para que a parte vencida (e que mentiu no juramento) pudesse compensar a declaração falsa prestada à sua divindade e, mais tarde, ao Estado, como uma pena punitiva pela ação desleal em juízo (poena temere ligantium). Sobre o assunto: KASER, 1992, p. 435-436; PUGLIESE, 1991, p. 69.

${ }^{35}$ Conforme dispunha o Título LXXXVIIII ("Das Execuções, que se fazem geralmente pelas Sentenças").

36 Sobre o assunto: PACHECO, 1999, p. 25.

${ }^{37}$ Conforme o Título XIX ("Quando será o autor obrigado formar seu libelo por escrito"), o autor só era obrigado a apresentar pedido escrito quando o valor pleiteado fosse superior a mil reais brancos.

${ }^{38}$ O Título VII ("Dos que podem e devem ser citados que compareçam pessoalmente em Juízo") determinava o comparecimento pessoal do réu em juízo, o Título XIII ("Do Autor, que não compareceu ao termo para que citou seu contendor, ou compareceu e se ausentou") previa o comparecimento de autor e réu perante o juiz, enquanto o Título XIV ("Em que modo se procederá contra o Réu que for 
(Título LXXXV), a apresentação de autor e réu diante do juiz, para apresentar provas e nomear testemunhas (Título XLII). Por outro lado, não havia previsão expressa da oralidade nos embargos à execução (Título LXXI) e não se repetiu a regra da identidade física do juiz (o Título XXIIII tratava somente de regras de suspeição e substituição), tendo em vista que a instrução não era acompanhada diretamente por ele.

As Ordenações Filipinas foram promulgadas em 1603, para revisar as leis vigentes, por ordem do rei Filipe I. Sua divisão seguia os cinco Livros, com o processo tratado no Livro Terceiro. Da mesma forma que as anteriores, as Ordenações Filipinas mantiveram a característica essencialmente escrita do processo, com alguns aspectos orais: o pedido inicial apresentado oralmente ao tabelião ou ao escrivão (Título XXX), a imediatidade (Título VII), a apresentação de autor e réu perante o juiz para apresentação de provas e indicação de testemunhas (Título LV) e o juramento (Título LII) ${ }^{39}$. Constituíram a principal fonte do Direito Processual no Brasil durante um intervalo de tempo extenso: permaneceram em vigor mesmo após a Independência, em 07/09/1822, por força de lei publicada em 20/10/1823 ${ }^{40}$. Posteriormente,

revel, e não comparecer ao termo, para que foi citado") tratava da revelia do réu que não se apresentasse diante do juiz.

${ }^{39}$ Comentando o processo português a partir do fim da Idade Média, Carlos Alberto Alvaro de Oliveira afirma que as mudanças jurídicas derivadas da Revolução Francesa (especialmente os Códigos Napoleônicos e o fim da influência do Direito Medieval sobre o processo) não produziram reflexos sobre o Direito Processual das Ordenações. A posterior Lei da Boa Razão, de 1769, influenciada pelo Iluminismo, que trazia um preceito racional de validação das normas jurídicas, também não provocou alterações relevantes sobre o processo português (OLIVEIRA, 2003, p. 33).

${ }^{40}$ Que "declara em vigor a legislação pela qual se regia o Brasil até 25 de Abril de 1821 e bem assim as leis promulgadas pelo Senhor D. Pedro, como Regente e Imperador daquela data em diante, e os decretos das Cortes Portuguesas que são especificados". 
foram parcialmente revogadas pelo Código Comercial em 1850 (para os processos de matéria comercial) e totalmente afastadas por meio do Regulamento 763 (Decreto no 763), de $19 / 09 / 1890^{41}$. Portanto, as Ordenações Filipinas foram a fonte do processo civil no Brasil por quase 300 anos, de 1603 a 1890 .

O Regulamento 737 (Decreto no 737, de 25/11/1850), sobre o processo comercial, passou a incidir ao processo civil por força do citado Regulamento $763^{42}$. Apesar de poucas formalidades, o processo do Regulamento 737 era predominantemente escrito. Quanto à oralidade, destacavam-se: a tentativa de conciliação prévia (judicial ou extrajudicial) em audiência, que condicionava a propositura judicial do pedido

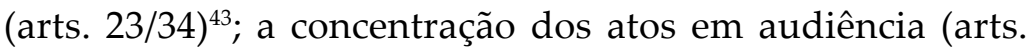
$27,32,127$ e 223$)^{44}$; e a publicação da sentença em audiência, como regra (arts. 233 e 235). Os arts. 236/245 tratavam das ações sumárias, que iniciavam com uma petição escrita, mas traziam a concentração dos atos em audiência e a possibilidade da apresentação da defesa do réu de forma oral ou escrita na própria audiência, seguida da instrução, com a sentença

${ }^{41}$ Sobre o histórico legislativo: OLIVEIRA, 2003, p. 33.

${ }^{42}$ Que determinava em seu art. 1º: "São aplicáveis ao processo, julgamento e execução das causas cíveis em geral as disposições do regulamento n. 737 de 25 de novembro de 1850 , exceto as que se contêm no titulo $1^{\circ}$, no capitulo $1^{\circ}$ do titulo $2^{\circ}$, nos capítulos $4^{\circ}$ e $5^{\circ}$ do titulo $4^{\circ}$, nos capítulos $2^{\circ}, 3^{\circ}$ e $4^{\circ}$ e secções $1^{\underline{a}}$ e $2^{\underline{a}}$ do capitulo $5^{\circ}$ do titulo $7^{\circ}$, e no titulo $8^{\circ}$ da primeira parte".

${ }^{43}$ Destaca-se o art. 33, que previa debates orais e apresentação de provas na audiência conciliatória: "Comparecendo as partes por si ou seus procuradores (art. 26), lida a petição, poderão discutir verbalmente a questão, dar explicações e provas, e fazer reciprocamente as propostas que lhes convier. Ouvida a exposição, procurará o Juiz chamar as partes a um acordo, esclarecendo-as sobre seus interesses, e inconvenientes de demandas injustas".

${ }^{44} \mathrm{O}$ réu era citado para o comparecimento em audiência para se buscar a conciliação e, no insucesso desta, apresentar contestação. Existindo necessidade de dilação probatória, previa-se o prazo de vinte dias para esse fim, o que incluía a designação de nova audiência para a oitiva das partes e das testemunhas. 
proferida na audiência seguinte. Contudo, o art. 241 determinava a redução a termo de todos os atos praticados oralmente.

A Constituição brasileira de 1891 permitiu que os Estados criassem seus Códigos de Processo, ao limitar a atribuição do Congresso Nacional para legislar apenas sobre o direito processual da Justiça Federal (art. 34, 23ํ). Porém, essa autoridade não foi exercida por todos os Estados; vários deles reproduziram as normas do Regulamento 737, e destacavam-se como originais os Códigos da Bahia e de São Paulo.

Com a Constituição de 1934, a União passou a ter competência privativa para legislar sobre direito processual (art. 5o , XIX, 'a'), o que ainda se mantém na Constituição de 1988 (art. 22, I).

Passados quase cinquenta anos de aplicação do Regulamento 737 ao processo civil, em 18/09/1939, foi finalmente promulgado o primeiro Código de Processo Civil brasileiro (Decreto-Lei no 1.608/39), que entrou em vigor no dia 01/02/1940. O CPC de 1939 dedica longa passagem à oralidade na Exposição de Motivos (elaborada por Francisco Campos, Ministro da Justiça na época $)^{45}$. Inicialmente, defende a incorporação da oralidade como parte indispensável do sistema ideal, posto que utilizada com êxito em quase todos os países europeus (e, apesar de Chiovenda, a Itália constituía exceção ao seu uso $)^{46}$. Em seguida são apontadas diversas críticas ao

${ }^{45}$ Daniel Mitidiero afirma que o CPC brasileiro de 1939 veio para substituir os Códigos estaduais (os quais contrariavam a cultura do centralismo jurídico) e "[...] mesclava alguns elementos modernos com institutos tipicamente pertencentes ao direito intermédio". Observava os princípios da oralidade e da publicidade, conferindo ao juiz o poder de direção do processo. Possua tanto elementos romanos e germânicos quanto manteve as influências lusitanas (MITIDIERO, 2005, p. 37).

46 “ORALIDADE, CONCENTRAÇÃO E IDENTIDADE DO JUIZ. [...] O processo oral atende a todas as exigências acima mencionadas: confere ao processo o caráter de instrumento público; substitui a concepção duelística pela concepção 
uso da oralidade no processo civil, mas todas elas confundem a oralidade com a mera prática verbal dos atos, equívoco que será desfeito adiante. O Código de 1939 previa a fixação dos pontos controversos para serem debatidos oralmente em audiência (art. 269) e adotou os princípios da identidade física do juiz (art. 120, parágrafo único) ${ }^{47}$, da publicidade dos atos processuais (art. $5^{\circ}$ ), a não interrupção da audiência, os debates orais e a sentença proferida em audiência (arts. 270/271). Por outro lado, a petição inicial, a contestação e a reconvenção deveriam ser obrigatoriamente escritas (arts. 158, 160 e 190).

Logo, apesar de sempre apresentar características orais, historicamente, o processo civil brasileiro é escrito, com exceção do CPC de 1939, que seguiu a doutrina de Chiovenda e adotou um processo oral, mas que vigorou no país durante apenas 34 anos.

autoritária ou pública do processo; simplifica a sua marcha, racionaliza a sua estrutura e, sobretudo, organiza-o no sentido de tornar mais adequada e eficiente a formação da prova, colocando o juiz em relação a esta na mesma situação em que deve colocar-se qualquer observador que tenha por objeto conhecer os fatos e formular sobre eles apreciações adequadas ou justas. O ponto é importante. No processo em vigor o juiz só entra em contato com a prova testemunhal ou pericial através do escrito a que foi reduzida. Não ouviu as testemunhas, não inspecionou as coisas e os lugares. Qual o grau de valor que conferirá ao depoimento das testemunhas e das partes, se não as viu e ouviu, se não seguiu os movimentos de fisionomia que acompanham e sublinham as palavras, se no escrito não encontra a atmosfera que envolvia no momento o autor do depoimento, as suas palavras ou o seu discurso? Que juízo formará sobre a situação dos lugares e a condição das coisas, descritas no laudo pericial, se de uma e de outra não tem nenhuma impressão pessoal?". O destaque à oralidade no CPC foi precedido de intensa campanha doutrinária pela adoção de um processo oral no Brasil. A Revista Forense $n^{\circ}$ 74, de maio de 1938, foi dedicada à oralidade, com artigos de juristas brasileiros e estrangeiros, como Giuseppe Chiovenda, José Alberto dos Reis, Francisco Morato, Bilac Pinto, Eduardo Augusto Garcia, Cunha Barreto, Lucio Bittencourt, Hans Semon e Victor Nunes Leal.

47 "Se, iniciada a instrução, o juiz falecer ou ficar, por moléstia, impossibilitado de julgar a causa, o substituto mandará repetir as provas produzidas oralmente, quando necessário". 


\section{A Oralidade no Processo Civil Brasileiro Atual e no Projeto do Novo CPC}

O CPC de 1973 (Lei no 5.869/73), em vigor desde 01/01/1974, traz, na sua Exposição de Motivos (redigida por Alfredo Buzaid, Ministro da Justiça e autor do projeto ${ }^{48}$, uma preocupação específica com a oralidade e suas implicações para o processo ${ }^{49}$.

Desse modo, o Código de 1973 não adotou um processo oral. Ao mencionar que, a fim de observar as peculiaridades da extensão territorial do país, Buzaid optou por uma "oralidade mitigada", nada mais fez do que substituir o processo

${ }^{48}$ Sobre a elaboração, influências, cenário cultural e principais aspectos do Código de Processo Civil de 1973: MITIDIERO, 2010, p. 165/194.

49 "II - Do Processo Oral. 13. O projeto manteve, quanto ao processo oral, o sistema vigente, mitigando-lhe o rigor, a fim de atender a peculiaridades da extensão territorial do país. O ideal seria atingir a oralidade em toda a sua pureza. Os elementos que a caracterizam são: $a$ ) a identidade da pessoa física do juiz, de modo que este dirija o processo desde o seu início até o julgamento; $b$ ) a concentração, isto é, que em uma ou em poucas audiências próximas se realize a produção das provas; $c$ ) a irrecorribilidade das decisões interlocutórias, evitando a cisão do processo ou a sua interrupção contínua, mediante recursos, que devolvem ao Tribunal o julgamento da decisão impugnada. Falando de processo oral em sua pureza, cumpre esclarecer que se trata de um tipo ideal, resultante da experiência legislativa de vários povos e condensado pela doutrina em alguns princípios. Mas, na realidade, há diversos tipos de processo oral, dos quais dois são os mais importantes: o austríaco e o alemão. Entre estes, a diferença, que sobreleva notar, concerne ao princípio da concentração. Ocorre, porém, que o projeto, por amor aos princípios, não deve sacrificar as condições próprias da realidade nacional. O Código de Processo Civil se destina a servir ao Brasil. Atendendo a estas ponderações, julgamos de bom aviso limitar o sistema de processo oral, não só no que toca ao princípio da identidade da pessoa física do juiz, como também quanto à irrecorribilidade das decisões interlocutórias. O Brasil não poderia consagrar uma aplicação rígida e inflexível de princípio da identidade, sobretudo porque, quando o juiz é promovido para comarca distante, tem grande dificuldade para retornar ao juízo de origem e concluir as audiências iniciadas. O projeto preservou o princípio da identidade física do juiz, salvo nos casos de remoção, promoção ou aposentadoria (art. 137). A exceção aberta à regra geral confirma-lhe a eficácia e o valor científico. 'O que importa', diz Chiovenda, 'é que a oralidade e a concentração sejam observadas rigorosamente como regra"'. 
oral pelo escrito. Como ver-se-á adiante, não existe processo misto, mas (predominantemente) oral ou escrito, razão pela qual a mitigação de uma característica importa na primazia da outra.

Assim, o Código de 1973, em suas duas fases (antes e depois do início das reformas em 1994) ${ }^{50}$, manteve um processo escrito, com alguns elementos orais: a identidade física do juiz (art. 132) ${ }^{51}$, a imediatidade (art. 446, II) ${ }^{52}$, a publicidade dos atos processuais e da audiência (arts. 155 e 444), a realização de audiência preliminar conciliatória, com a fixação dos pontos controversos (art. 331); a produção de provas em audiência como regra (art. 336); a possibilidade de oitiva do perito ou do assistente técnico em audiência para prestar esclarecimentos (art. 435); a não interrupção da audiência como regra, os debates orais e a sentença proferida em audiência (em regra) (arts. 453/456); a apresentação oral do agravo retido contra decisão interlocutória proferida em audiência (art. 523, § $3^{\circ}$ ); a suscitação oral de contradições na transcrição dos atos processuais praticados diante do juiz (art. 169, $\S \S 2^{\circ}$ e $3^{\text {o }}$, inseridos pela Lei $\mathrm{n}^{\mathrm{o}} 11.419 / 2006$ ); e a prevalência da oralidade no procedimento sumário, com a concentração de atos em audiência: a decisão oral da impugnação ao valor da causa ou de controvérsia sobre a natureza da demanda, a apresentação de resposta oral ou escrita pelo

${ }^{50}$ Daniel Mitidiero utiliza a expressão Código Buzaid para salientar a existência do sistema processual criado por Alfredo Buzaid (vigente de 1976/1994) e para diferenciá-lo do sistema atual, que denomina de "Código Reformado" (vigente a partir de 1994, com as reformas realizadas até 2006) (MITIDIERO, 2010, p. 176).

51 “O juiz, titular ou substituto, que concluir a audiência julgará a lide, salvo se estiver convocado, licenciado, afastado por qualquer motivo, promovido ou aposentado, casos em que passará os autos ao seu sucessor".

52 "Compete ao juiz em especial: [...] proceder direta e pessoalmente à colheita das provas". 
réu, os debates e a sentença oral. De outro lado, permite a substituição de memoriais orais por escritos, quando existir questões complexas de fato ou de direito (art. 454, $\S 3^{\circ}$ ).

$\mathrm{O}$ art. 336 do CPC estabelece a prova oral como regra no processo civil: "Salvo disposição especial em contrário, as provas devem ser produzidas em audiência".

Acerca da necessidade da forma escrita para a documentação do que for relevante para o processo, o Código de Processo Civil brasileiro possui regra que autoriza apenas às partes a gravação dos depoimentos das testemunhas, mas obriga a documentação do ato para o processo: "Art. 417. O depoimento, datilografado ou registrado por taquigrafia, estenotipia ou outro método idôneo de documentação, será assinado pelo juiz, pelo depoente e pelos procuradores, facultando-se às partes a sua gravação".

Por outro lado, a oralidade incide nos Juizados Espe ciais Cíveis desde o pedido inicial até o cumprimento da decisão, ressalvada a forma escrita para os atos essenciais; é permitida a gravação das audiências, com a documentação limitada ao que for reputado essencial para o processo; nos termos do art. 13, § 30, da Lei no 9.099/95: “Apenas os atos considerados essenciais serão registrados resumidamente, em notas manuscritas, datilografadas, taquigrafadas ou estenotipadas. Os demais atos poderão ser gravados em fita magnética ou equivalente, que será inutilizada após o trânsito em julgado da decisão" (regra incidente sobre os Juizados Especiais Cíveis Estaduais, Federais e da Fazenda Pública).

Ainda, o art. 33 da Lei no 9.099/95 positivou o do princípio da concentração dos atos instrutórios, em virtude do qual “[...] os atos processuais devem ser, tanto quanto possível, 
reunidos em um mesmo momento, impedindo que o procedimento se delongue em um número indefinido de etapas e fases". Com base nesse princípio, pode ser indeferida a expedição de cartas precatórias ou a realização de outras provas exteriores à audiência de instrução e julgamento ${ }^{53}$. Além disso, caso uma das partes apresente documentos novos na audiência, a parte contrária deve se manifestar sobre eles no ato, sem a interrupção deste ou a concessão de prazo para impugnação (art. 29, parágrafo único, da Lei nº 9.099/95).

A Lei $\mathrm{n}^{\mathbf{0}}$ 10.259/2001 inovou ao admitir expressamente o recebimento de petições por meio eletrônico (art. $8^{\circ}, \S 2^{\circ}$ ). Deriva desse critério a possibilidade de gravação de atos processuais não essenciais, a qual pode ser inutilizada após o trânsito em julgado da sentença (arts. 13, § 3º , e 36, ambos da Lei n⿳⺈ 9.099/95).

A despeito de o Código de Processo Civil em vigor possuir uma grande quantidade de elementos orais, os atos praticados oralmente são reduzidos a termo ou são facultativamente praticados na forma oral ou escrita. Por essa razão, apesar da intenção de Alfredo Buzaid, e mesmo após as reformas de 1994/2006, o processo do Código de Processo Civil de 1973 é escrito (na denominada - de forma equivocada - "oralidade mitigada)".

E essa orientação segue no projeto do novo Código de Processo Civil (PL no 166/2010 do Senado Federal), que estabelece um processo civil escrito, com alguns elementos

${ }^{53}$ O Enunciado no 24 dos Juizados Especiais Estaduais Cíveis de Belo Horizonte prevê que "é dispensável a expedição de carta precatória nos Juizados Especiais Cíveis, cumprindo-se os atos nas demais comarcas, mediante via postal, por ofício do Juiz, fax, telefone ou qualquer outro meio idôneo de comunicação". De semelhante teor é o Enunciado no 33, do Fórum Permanente de Juízes Coordenadores dos Juizados Especiais Cíveis e Criminais do Brasil. 
de oralidade, conforme os dispositivos do PL originário: (a) a oralidade é listada como um princípio informador da conciliação e da mediação (art. 134), mantendo-se a realização de audiência preliminar conciliatória (art. 333); (b) a identidade física do juiz (art. 112); (c) é prevista a redução a termo de todos os atos judiciais proferidos oralmente (art. 160), o que constitui um retrocesso, especialmente diante da informatização e dos processos judiciais eletrônicos, que permitem com maior facilidade e menores custos a gravação (inclusive a audiovisual) dos atos processuais (o parágrafo único do referido art. 160 utiliza expressões como taquígrafo e datilógrafo, fazendo o Código voltar ao século XIX); (d) a suscitação oral de contradições na transcrição dos atos processuais praticados diante do juiz (art. 164, § 2o); (e) a substituição de memoriais orais por escritos, quando existir questões complexas de fato ou de direito (art. 359, $\S 2^{2}$ ); (f) a publicidade dos atos processuais e da audiência (arts. 152 e 363); (g) a produção de provas em audiência como regra (art. 428); (h) a possibilidade de oitiva do perito ou do assistente técnico em audiência para prestar esclarecimentos (art. 458); (i) a não interrupção da audiência como regra, os debates orais e a sentença proferida em audiência (em regra) (arts. 358/361).

\section{Considerações Finais}

Viu-se a ocorrência de substituições históricas sucessivas entre oralidade e escrita, que alternadamente caracterizaram o processo civil.

Conforme ressalva Attilio Nicora, a oralidade não se confunde com a oratória, ou seja, não indica apenas a prática de atos orais no processo. E mais: a oralidade não é a ditadura 
da oratória, do verbo ou da fala, tampouco impede a documentação de determinados atos processuais (como a sentença ou, pelo menos, sua parte dispositiva). Há um predomínio, mas não a exclusividade do uso da palavra oral. Acerca do uso da escrita, Francisco Morato afirma que "[...] no procedimento escrito, a escritura é a forma das deduções, enquanto que, no oral, não é senão o registro das declarações ou deduções que se vão fazer na audiência" (MORATO, 1938, p. 14).

A oralidade compreende a publicidade, a imediação do juiz, a irrecorribilidade imediata das decisões interlocutórias, a concentração de atos e a identidade física do juiz. Logo, a prevalência de atos orais sobre os escritos é apenas uma entre suas características.

Ademais, a prática de atos orais não significa que o processo seja oral, do mesmo modo que a realização de atos escritos não quer dizer que o processo seja escrito ${ }^{54}$.

Conforme constou da Exposição de Motivos do CPC brasileiro de 1939, o processo oral confere caráter público ao processo, simplifica-o, racionaliza-o e organiza-o, situando o juiz em relação à prova em uma condição de observador direto. No procedimento oral, o juiz desempenha um papel mais ativo e presente, pois mantém contato imediato com as partes, advogados, peritos etc.

Conforme destacam Mortara e Chiovenda, a oralidade (e a concentração de atos dela derivada) permite a simplificação do processo e sua celeridade ${ }^{55}$ (o que não signi-

\footnotetext{
${ }^{54}$ Nesse sentido: CHIOVENDA, 1969, p. 251.

55 Nesse sentido, e analisando o princípio da oralidade a partir da obra de Mortara: CHIOVENDA, 1924, p. 6-7. Todavia, Chiovenda ressalva que, à época (ou seja, em 1924, na Itália), as vantagens abstratas da oralidade ainda eram desejáveis (e não efetivas), pois encontravam obstáculos em sua aplicação prática.
} 
fica que a oralidade necessariamente simplifica e acelera o andamento processual). Nas palavras de Morato, a oralidade "[...] comunica vida e eficácia ao processo" e "assegura na prática o verdadeiro sentido e finalidade das leis", além de trazer como vantagens: a publicidade das decisões judiciais, a celeridade, a economia judicial, faz com que a convicção do julgador seja efetivamente formada após ouvir os advogados e as próprias partes, e obsta "[...] que os juízes julguem sem ouvir e examinar suas razões", pois "na oralidade a audiência é forçada" (MORATO, 1938, p. 11 e 16).

Apesar de sempre apresentar características orais, historicamente o processo civil brasileiro é escrito, com exceção do CPC de 1939, que seguiu a doutrina de Giuseppe Chiovenda e adotou um processo oral, o qual vigorou no país durante apenas 34 anos.

Criticando a falta de eficiência e o formalismo existente no processo escrito, Pérez-Ragone e Vélez afirmam que há uma "invisibilidade virtual" do juiz no processo, por não existir o contato direto com as partes, tampouco com os meios de prova por elas produzidos (PÉREZ-RAGONE; VÉLEZ, 2009, p. 365). Aproximadamente um século antes, Chiovenda criticou o processo escrito dos primeiros Códigos italianos, ao afirmar que o Código Processual italiano de 1865 “[...] não chegou ao extremo de negar às partes o direito de ver o rosto de seu juiz na audiência em que a causa se encerra; mas reduziu esse encontro do juiz e as partes a uma mera formalidade" (CHIOVENDA, 1969, p. 232).

No Brasil, o CPC atual e o projeto do novo CPC negam esse direito à parte, que em muitos processos não conhece $o$ juiz de seu processo, ou até mesmo a parte contrária. 


\section{Referências}

CAMPITELLI, Adriana. Processo. I. Processo civile: b) Diritto intermedio. In: Enciclopedia del Diritto. v. XXXVI. Milano: Giuffrè, 1987. p. 79-101.

CAPPELLETTI, Mauro. La testimonianza della parte nel sistema dell'oralità: contributo alla teoria della utilizzazione probatoria del sapere delle parti nel processo civile. Parte Prima. Milano: Giuffré, 1962.

CARDOSO, Oscar Valente. Direct examination e cross-examination no processo civil brasileiro. Revista Dialética de Direito Processual, São Paulo, n. 75, p. 83-91, jun. 2009.

CHIOVENDA, Giuseppe. La idea romana en el proceso civil moderno. In: CHIOVENDA, Giuseppe. Ensayos de derecho procesal civil. v. I. Buenos Aires: Ediciones Jurídicas Europa-América, 1949. p. 351-372.

. L'oralità e la prova. Rivista di diritto processuale civile, Padova, n. I, v. I, p. 5-32, 1924.

. Relación sobre el proyecto de reforma del procedimiento elaborado por la comisión de postguerra. In: CHIOVENDA, Giuseppe. Ensayos de derecho procesal civil. v. II. Buenos Aires: Ediciones Jurídicas Europa-América, 1969.

. Romanesimo e germanesimo nel processo civile. In: CHIOVENDA, Giuseppe. Saggi di diritto processuale civile. v. I. Roma: Foro Italiano, 1930. p. 181-224.

FIUZA, César. Algumas linhas de processo civil romano. In: FIUZA, César. Direito processual na história. Belo Horizonte: Mandamentos, 2002.

GAIUS. Institutas do jurisconsulto Gaio. São Paulo: RT, 2004.

GUEDES, Jefferson Carús. O princípio da oralidade: procedimento por audiências no direito processual civil brasileiro. São Paulo: RT, 2003.

KASER, Max. Direito privado romano. Lisboa: Fundação Calouste Gulbenkian, 1992.

MARQUES, José Frederico. Manual de direito processual civil. v. I. Campinas: Bookseller, 1997. 
MITIDIERO, Daniel. Colaboração no processo civil: pressupostos sociais, lógicos e éticos. 2. ed. São Paulo: RT, 2011.

. Elementos para uma teoria contemporânea do processo civil brasileiro. Porto Alegre: Livraria do Advogado, 2005.

. O processualismo e a formação do Código Buzaid. Revista de Processo, São Paulo, n. 183, p. 165-194, maio 2010.

MORATO, Francisco. A oralidade. Revista Forense, Rio de Janeiro, n. 74, Fascículo 419, p. 11-18, maio 1938.

NICORA, Attilio. Il princípio di oralità nel diritto processuale civile italiano e nel diritto processuale canonico. Roma: Università Gregoriana, 1977.

OLIVEIRA, Carlos Alberto Álvaro de. Do formalismo no processo civil. 2. ed. São Paulo: Saraiva, 2003.

. Poderes do juiz e visão cooperativa do processo. Revista da Ajuris, Porto Alegre, n. 90, p. 55-84, jun. 2003.

OLIVEIRA, Carlos Alberto Álvaro de; MITIDIERO, Daniel. Curso de processo civil. v. 1. São Paulo: Atlas, 2010.

PACHECO, José da Silva. Evolução do processo civil brasileiro. 2. ed. Rio de Janeiro: Renovar, 1999.

PÉREZ-RAGONE, Álvaro; VÉLEZ, Diego Palomo. Oralidad y prueba: comparación y análisis crítico de las experiencias reformadoras del proceso civil en Alemania y España. Revista de derecho de La Pontificia Univesidad Católica de Valparaíso, Valparaíso, n. XXII, p. 363-406, jan./jun. 2009.

PUGLIESE, Giovanni. Istituzioni di diritto romano. Torino: G. Giappichelli, 1991.

TUCCI, José Rogério Cruz; AZEVEDO, Luiz Carlos de. Lições de história do processo civil romano. São Paulo: RT, 2001.

Submissão: $16 / 11 / 2012$

Aceito para Publicação: 15/08/2013 



\title{
O Conceito do Político
}

e a Possibilidade da Filosofia

Política na Modernidade:

\section{uma Leitura Crítica de Carl Schmitt por Leo Strauss}

\author{
The Concept of the Political and the Possibility \\ of Political Philosophy in Modernity: \\ a Critical Reading of Carl Schmitt by Leo Strauss
}

Bruno Irion Coletto*

Resumo: $\mathrm{O}$ artigo busca explorar as críticas e os comentários lançados por Leo Strauss acerca de um dos principais livros de Carl Schmitt, intitulado O Conceito do Político. Sob o pressuposto da existência de um "diálogo escondido" entre os dois filósofos, e sob o pano de fundo da disputa entre a Teologia Política e a Filosofia Política, primeiramente explorar-se-ão os aspectos fundamentais da obra schmittiana, enquadrando-a como a afirmação do âmbito político perante o projeto de um liberalismo individualista despolitizador moderno. Compreendidos os aspectos fundamentais do pensamento de Schmitt, analisar-se-ão as concordâncias e as críticas de Strauss, especialmente acerca do critério de existência da política, ou seja, do critério que separa os homens entre amigos e inimigos, fundando a política. Strauss, fazendo uma releitura daquilo que Schmitt chamou de "pergunta de vida e morte", demonstra como a pluralidade interna à comunidade, diferentemente daquilo que pensava Schmitt, é proveniente da natureza humana. Strauss, portanto, faz uma releitura da pergunta de vida e morte, estabelecendo a diferença fundamental entre aquilo que chama de Filosofia Política e a Teologia Política de Schmitt.

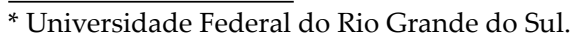


O Conceito do Político e a Possibilidade da Filosofia Política na Modernidade...

Palavras-chave: Filosofia Política. Teologia Política. Leo Strauss. Carl Schmitt. O Conceito do Político.

Abstract: The article explores the critics and comments of Leo Strauss on one of Carl Schmitt's main books, titled The Concept of the Political. Under the assumption of a "hidden dialogue" between these two philosophers, and with the background of the dispute between Political Theology and Political Philosophy, fundamental aspects of Schmitt's work are explored initially, framing it as an assertion of the political framework before the project of a modern depoliticizing individualistic liberalism. Once the fundamental aspects of Schmitt's thoughts are understood, Strauss's concordances and critiques are analyzed, especially regarding the politics existence criterion, i.e. the criterion that separates men between friends and foes, founding the politics. Strauss, reinterpreting what Schmitt called "question of life and death," demonstrates how community's internal plurality, unlike what Schmitt thought, comes from human nature. Strauss therefore makes a rereading of the question of life and death, establishing the fundamental difference between what he calls Political Philosophy and Schmitt's Political Theology.

Keywords: Political Philosophy. Political Theology. Leo Strauss. Carl Schmitt. The Concept of the Political.

\section{Introdução}

Carl Schmitt inicia o prefácio à edição de 1963 de seu famoso $O$ Conceito do Político com uma referência a Aristóteles. Aqui começaremos do mesmo modo, dizendo que o homem é um animal racional e político. Cheia de significados e de consequências, esta assertiva localiza-nos dentro da tradição ocidental, o que é essencial para o debate de questões que envolvem a filosofia política e a teoria do estado. Dito isso, cabe esclarecer que os apontamentos ora apresentados são 
fruto do diálogo que buscamos estabelecer entre diferentes enfoques acerca do mesmo tema: as relações entre o âmbito do direito e o âmbito da política, aqui com enfoque especial a ser dado à "possibilidade da filosofia política na modernidade"

Pois bem, tendo esta contextualização sempre em mente, o presente artigo buscará tratar do conceito do político, mas não apenas da forma como delineada por Schmitt, como também verificando as críticas e os comentários trazidos por Leo Strauss, relevante filósofo político alemão que se destacou nos Estados Unidos, lecionando na Universidade de Chicago. Sagaz e incisivo, Strauss traz importantíssimas contribuições à compreensão crítica da tese de Schmitt, a começar pela afirmação de que o texto de Schmitt debate a "a ordem das coisas humanas, ou seja, a questão do Estado" 2 . Ora, Schmitt começa O Conceito do Político justamente justificando que " $[\mathrm{o}]$ conceito do Estado pressupõe o conceito do político" ${ }^{\prime \prime}$, pois o conceito de Estado apenas adquiriria seu sentido mediante o marco característico do político (e tornando-se incompreensível caso a essência do político seja mal compreendida $)^{4}$. A sagacidade de Strauss, demonstrando como Schmitt estava empenhado em criticar o projeto despolitizador moderno, mostra-se essencial para a

\footnotetext{
1 STRAUSS, Leo. The Three Waves of Modernity. In: An Introduction to Political Philosophy: Ten Essays by Leo Strauss. Edited with an introduction by Hilail Gildin. Detroit: Wayne State University Press, 1989. p. 81.

2 A primeira frase de seus comentários é "The treatise by Schmitt serves the question of the 'order of the human things', that is, the question of the state". STRAUSS, Leo. Notes on Carl Schmitt, The Concept of the Political. In: MEIER, Heinrich. Carl Schmitt and Leo Strauss: the hidden dialogue. Translated by J. Harvey Lomax. Chicago and London: The University of Chicago Press, 1995. p. 91

3 SCHMITT, Carl. O Conceito do Político. Tradução de Alvaro L. M. Valls. Petrópolis: Vozes, 1992. p. 43.

4 SCHMITT. O Conceito do Político, 1992, p. 43.
} 
O Conceito do Político e a Possibilidade da Filosofia Política na Modernidade...

compreensão do debate em que Schmitt estava compreendido. Aqui almejaremos compreender alguns dos principais aspectos do "diálogo oculto" mantido entre os dois filósofos.

O debate entre Strauss e Schmitt, como explica Meier, é o debate entre a "teologia política" e a "filosofia política", na medida em que são representantes de diferentes visões acerca da política e da vida boa, ambas, contudo, fulcradas na tradição ocidental: enquanto uma é proveniente da concepção bíblica, a outra é proveniente da concepção filosófica de vida boa $^{5}$. Dessa forma, que o ponto-chave para entender a diferença do pensamento entre eles reside na compreensão da distinção entre teologia e filosofia política ${ }^{6}$.

A filosofia política, surgida em um período específico da história (com Sócrates) ${ }^{7}$, é o resultado da busca explícita e consciente do melhor regime político. É o esforço pela substituição das opiniões pelo conhecimento ${ }^{8}$. Ela trata, portanto, dos assuntos políticos de maneira que seja relevante para a vida política. A teologia política, ao invés de se limitar ao que é acessível aos homens por meio da opinião alçada a conhecimento, vem a ser o ensinamento político baseado na revelação divina9: enquanto a uma é baseada em um conhecimento que

5 PANGLE, Thomas L. Leo Strauss: an introduction to his thought and intellectual legacy. Baltimore: The Johns Hopkins University Press, 2006. p. 26-27.

6 MEIER, Carl Schmitt and Leo Strauss: the hidden dialogue, 1995, p. XIV.

7 STRAUSS, Leo. Introduction to History of Political Philosophy. In: An Introduction to Political Philosophy: Ten Essays by Leo Strauss, 1989. p. 160.

8 STRAUSS, Leo. What is Political Philosophy? In: What is Political Philosophy and other studies. Chicago and London: The University of Chicago Press, 1988. p. 11-12. Tal compreensão da filosofia política pressupõe a existência de uma verdade, de uma ordem das coisas, pois se não se tem como pressuposto a possibilidade da verdade, não haveria sentido em ter opinião. A opinião é uma opinião sobre, acerca da verdade.

9 STRAUSS, What is Political Philosophy?, 1988, p. 13. 
não é acessível ao homem dotado de uma razão desassistida, a outra busca conduzir seus questionamentos sem se limitar por um código divino ${ }^{10}$. Os dois conceitos, portanto, não se diferenciam da mesma maneira que duas disciplinas ou dois domínios relativamente independentes do humano. Em verdade, eles são determinados pelas suas respostas absolutamente opostas à pergunta: como eu vou viver? É este antagonismo na resposta que estabelece a diferença principal, na maneira de viver, em relação às posições de cada um sobre moral, política, revelação e história ${ }^{11}$.

Portanto, apesar da grande semelhança existente entre a filosofia política e a teologia política, suas divergências são insuperáveis ${ }^{12}$. Strauss concorda com as críticas à modernidade lançadas por Schmitt, mas de um outro ponto de vista, do ponto de vista da filosofia política: enquanto para Strauss o homem, pró-ativamente, deve fazer a pergunta fundamental (o que é certo?), para Schmitt a questão (amigo/ inimigo) é colocada ao homem não pró-ativo, passivo ${ }^{13}$. Dessa forma, o confronto entre teologia política e filosofia política cumpre papel de auxiliar o presente estudo, pois tratar e compreender essa diferença é tratar também do debate entre Schmitt e Strauss ${ }^{14}$.

10 TANGUAY, Daniel. Leo Strauss: An Intellectual Biography. New Haven: Yale University Press, 2007. p. 5.

${ }^{11}$ MEIER, Carl Schmitt and Leo Strauss: the hidden dialogue, 1995, p. XV-XVI.

12 MEIER, Carl Schmitt and Leo Strauss: the hidden dialogue, 1995, p. 43.

${ }^{13}$ MEIER, Carl Schmitt and Leo Strauss: the hidden dialogue, 1995, p. 42.

${ }^{14}$ STRAUSS estava preocupado com o que chamou de "Crise dos Nossos Tempos" ou de "Crise do Ocidente". Nesse contexto é que se compreende, segundo Pangle, a ocupação Straussiana com o problema teológico-político. Juntamente com a "querela entre Antigos e Modernos", o "problema teológico-político" é a outra causa por ele identificada da Crise do Ocidente (PANGLE, Leo Strauss: an introduction to his thought and intellectual legacy, 2006, p. 26-27). 
O contexto do debate passa pela Alemanha pré-nazista. Schmitt foi um dos grandes acadêmicos que revisou e criticou positivamente o trabalho inicial de Strauss - então no início de sua carreira acadêmica - sobre Hobbes. Isto rendeu a Strauss, pensador judeu, financiamento acadêmico permitindo-lhe deixar a Alemanha no momento em que Schmitt assumia altos cargos no governo nazista ${ }^{15}$. Strauss, posteriormente, criticou O Conceito do Político, o que levou Schmitt a revisar e fazer emendas nas suas publicações posteriores ${ }^{16}$.

Para Strauss, a visão de Schmitt acerca do problema da política feita por uma teologia política não constituía solução adequada. Strauss defendeu a volta a uma compreensão clássica da natureza humana, e um retorno à filosofia política, como na tradição dos antigos filósofos. Se para ele a filosofia política tinha sua raiz na política verdadeira, ou seja, no embate de opiniões em busca do conhecimento, a política não pressupunha uma divisão entre amigos e inimigos, ou uma consideração acerca do risco de guerra externa - como em Schmitt -, mas sim a controvérsia de grupos dentro da comunidade, dentro da polis, lutando pelo poder político e pela definição de quem e de como se deve governar:

Classical political philosophy was related to political life directly, because its guiding subject was a subject of actual political controversy carried on in pre-philosophic political life. [...] all political controversies presuppose the existence of the political community [...]. [T] he ultimate aim of foreign policy is not essentially controversial. Hence

15 STRAUSS, Leo. Three letters to Carl Schmitt. In: MEIER, Heinrich. Carl Schmitt and Leo Strauss: the hidden dialogue, 1995. p. 121-128.

${ }^{16}$ Mesmo que tais alterações não tenham sido explicitamente relacionadas às críticas de Strauss, Schmitt mudou inúmeras passagens em edições subsequentes em uma resposta "oculta" a Strauss, conforme amplamente demonstrado e explorado em MEIER, Carl Schmitt and Leo Strauss: the hidden dialogue, 1995. 
classical political philosophy is not guided by questions concerning the external relations of the political community. It is concerned primarily with the inner structure of the political community, because that inner structure is essentially the subject of such political controversy as essentially involves the danger of civil war. ${ }^{17}$

Da consideração sobre o que realmente ocorre dentro da comunidade (política) é que emerge a filosofia política: é da vida política que surge a discussão sobre o melhor regime ${ }^{18}$.

Ainda a título introdutório, cabe destacar a importância da resenha de Strauss para o seu próprio pensamento. Comentários ao Conceito do Político de Carl Schmitt foi escrito por Strauss em 1932. Anos depois, em 1965, ele republicou em inglês seu primeiro livro, originalmente publicado em alemão em 1930, intitulado A Crítica da Religião de Spinoza. Segundo Strauss, este livro tinha a premissa, posteriormente revista, de que um retorno à filosofia pré-moderna era impossível. Então, não inteiramente por acaso, ele acrescentou seus comentários como adendo a esta nova edição do livro, justamente porque representava a primeira expressão da sua mudança de opinião acerca da filosofia política pré-moderna ${ }^{19}$. É a partir de então que Strauss se lança no objetivo de demonstrar que houve uma ruptura na modernidade. Ele começa a desenvolver a tese de que a ciência política moderna

\footnotetext{
17 STRAUSS, Leo. On Classical Political Philosophy. In: What is Political Philosophy and other studies, 1988. p. 84-85

18 STRAUSS, On Classical Political Philosophy, 1988, p. 90.

${ }^{19}$ ZUCKERT, Catherine; ZUCKERT, Michael. The truth about Leo Strauss: political philosophy and American democracy. Chicago and London: The University of Chicago Press, 2008, p. 186. Semelhante referência também é dada por SHELL, Susan. Taking Evil Seriously: Schmitt's "Concept of the Political" and Strauss's "True Politics". In: DEUTSCH, Kenneth L.; NICGORSKI, Walter (Ed.). Leo Strauss: political philosopher and Jewish thinker. Lanham: Rowman \& Littlefield Publishers, INC., 1994. p. 175.
} 
O Conceito do Político e a Possibilidade da Filosofia Política na Modernidade...

negava a possibilidade da filosofia política "verdadeira" ${ }^{20}$. Por esse motivo é que seus estudos se voltam para Hobbes: compreender corretamente as consequências do pensamento hobbesiano passou a ser essencial em uma análise da crise da modernidade. É para iniciar uma reflexão de certas interpretações de Hobbes que se prestou o comentário que escreveu sobre o texto de Schmitt. No último parágrafo de seus comentários é que ele explica seu objetivo primeiro:

The critique introduced by Schmitt against liberalism can therefore be completed only if one succeeds in gaining a horizon beyond liberalism. In a such horizon Hobbes completed the foundation of liberalism. A radical critique of liberalism is thus possible only on the basis of an adequate understanding of Hobbes. To show what can be learned from Schmitt in order to achieve that urgent task was therefore the principal intention of our notes ${ }^{21}$.

Ou seja, apenas será possível compreender a crise da modernidade quando se compreender adequadamente os seus primórdios, com Hobbes ${ }^{22}$. É neste contexto, debatendo uma interpretação de Hobbes, que ele lança os seus comentários ao O Conceito do Político.

Veremos, a seguir, uma breve apresentação da obra de Schmitt para então passarmos à compreensão dos comentários de Strauss. Notaremos que os comentários de Strauss, por um lado fazem coro à crítica ao liberalismo lançada por

\footnotetext{
${ }^{20}$ Tese mais de uma vez apresentada por ele, em diferentes livros e artigos.

${ }^{21}$ STRAUSS, Notes on Carl Schmitt, The Concept of the Political, 1995, p. 119.

${ }^{22}$ Para Shell o principal objetivo de Strauss com os comentários que faz à obra de Schmitt é compreender Hobbes corretamente e então criticar o liberalismo (SHELL, Taking Evil Seriously: Schmitt's "Concept of the Political” and Strauss's “True Politics", 1994, p. 186).
} 
Schmitt, objetivando uma defesa do político ${ }^{23}$, e por outro lado, buscam esclarecer a tese dele para, ao fazê-lo, primeiro torná-lo um adversário mais forte ${ }^{24}$, para então criticá-lo, fazendo uma "verdadeira" defesa da política.

\section{Conceito do Político de Carl Schmitt como a Afirmação do Âmbito Político Perante o Liberalismo Individualista Despolitizador Moderno}

\subsection{Contextualização da Obra}

O Conceito do Político é escrito em um determinado contexto e com um objetivo claro: criticar a "despolitização" da era moderna e apontar os paradoxos do liberalismo ${ }^{25}$. Para tanto, Schmitt empenha-se em afirmar um espaço autônomo para o âmbito da política, já que "[...] pela substituição de critérios políticos por aqueles da racionalidade econômico-capitalista, a sociedade liberal-burguesa perdeu a possibilidade de refletir sobre um lugar autônomo do político" ${ }^{26}$. "Despolitização" é justamente o objetivo do projeto moderno, de tal modo que a afirmação da posição do político é o contraponto de Schmitt a ele ${ }^{27}$.

${ }^{23}$ SHELL, Taking Evil Seriously: Schmitt's "Concept of the Political" and Strauss's "True Politics", 1994, p. 175.

${ }^{24}$ MEIER, Carl Schmitt and Leo Strauss: the hidden dialogue, 1995, p. 11.

${ }^{25}$ FLICKINGER, Hans Georg. A Luta pelo Espaço Autônomo do Político. In: SCHMITT, O Conceito do Político, 1992.

${ }^{26}$ FLICKINGER, A Luta pelo Espaço Autônomo do Político, 1992, p. 25.

${ }_{27}$ STRAUSS, Notes on Carl Schmitt, The Concept of the Political, 1995, p. 92: “The present situation is characterized by the fact that a process three hundred years old has "reached its end". The age at the end of which we find ourselves is "the age of neutralizations and depoliticizations." Depoliticization not only is the accidental or even necessary result of the modern development but is its original and 
Então, para compreender melhor sua leitura histórica da humanidade (ou, melhor dizendo, do ocidente, assim considerado enquanto história política da Europa) talvez fosse indicado ao leitor começar a leitura justamente pelo último capítulo, intitulado A Era das Neutralizações e Despolitizações ${ }^{28}$. É neste fechamento da obra que ele contextualiza sua crítica ao liberalismo individualista despolitizador moderno, o qual, segundo ele, buscaria extinguir o âmbito político. Ali explica que "[...] há quatro grandes passos, simples, seculares, [...] que a humanidade europeia desde o século XVI tem dado [...] de uma região central para outra [e que] constitui o conteúdo de nosso desenvolvimento cultural" ${ }^{29}$. Segundo Schmitt, a compreensão do deslocamento dos centros culturais será fundamental para a compreensão das diferentes gerações - e, acrescentamos, será também fundamental para a compreensão dos objetivos de Schmitt com O Conceito do Político. Assim, temos que no século XVI há uma concentração no teológico, no século XVII no metafísico, no século XVIII no humanitário-moral e no século XIX no econômico. Essa "alternância das áreas dominantes" foi causada pela busca de uma área neutra pela humanidade europeia, que

authentic goal; the movement in which the modern spirit has gained its greatest efficacy, liberalism, is characterized precisely by the negation of the political. If liberalism has already become implausible, if it accordingly must be countered by "another system", then the first word against liberalism must in any case be: the position of the political. And if liberalism believed that by means of its negation of the political it could bring about the foundation of the state or, more accurately, the establishment of rational social relations, after the failure of liberalism one cannot help thinking that the state can be understood only from the position of the political. Thus Schmitt's basic thesis is entirely dependent upon the polemic against liberalism, it is to be understood only qua polemical, only "in terms of concrete political existence".

${ }^{28}$ SCHMITT, O Conceito do Político, 1992, p. 106-120.

29 SCHMITT, O Conceito do Político, 1992, p. 108. 
almejava, após os conflitos religiosos, a cessação das lutas e um espaço no qual fosse possível o entendimento e a concordância mútua $^{30}$. Contudo a humanidade europeia, desde então, “[...] caminha sempre de uma área de lutas para uma área neutra; a área neutra recém-adquirida torna-se sempre imediatamente região de lutas e se faz necessário procurar novas esferas neutras" ${ }^{\prime 31}$.

Finaliza Schmitt criticando a "[...] crença na técnica [...] que poderia crer ter encontrado o solo absoluta e definitivamente neutro" ${ }^{\prime 2}$. Entretanto, em que pese o fato de que a "[...] esfera da técnica pareceu ser uma esfera da paz, do entendimento e da reconciliação" ${ }^{33}$, em verdade não há neutralidade, pois a técnica é apenas um instrumento que pode ser utilizado para qualquer finalidade. Da técnica não brota e não brotará nenhuma decisão. Este é o âmbito do político: "[...] a técnica nada pode fazer senão intensificar a paz ou a guerra" ${ }^{34}$, e decidir sobre a paz e a guerra (sobre quem são os amigos e os inimigos) é compromisso da política.

A afirmação do âmbito político contra um processo individualista despolitizador moderno, eis a chave de leitura para a obra de Schmitt.

\footnotetext{
${ }^{30}$ SCHMITT, O Conceito do Político, 1992, p. 108-109 e 114.

${ }^{31}$ SCHMITT, O Conceito do Político, 1992, p. 115. E continua, fazendo a relação com as etapas que havia delineado: "Das guerras religiosas surgiram as guerras nacionais do século XIX, meio determinadas ainda culturalmente, meio determinadas já economicamente. E por fim, surgiram guerras simplesmente econômicas" (ibidem).

32 SCHMITT, O Conceito do Político, 1992, p. 115.

33 SCHMITT, O Conceito do Político, 1992, p. 116.

${ }^{34}$ SCHMITT, O Conceito do Político, 1992, p. 119.
} 


\subsection{Aspectos Principais de O Conceito do Político}

"O conceito do Estado pressupõe o conceito do político" ${ }^{35}$. É famosa a frase de abertura do livro que teve sua primeira versão de $1927^{36}$. O conceito de Estado, para Schmitt, só adquire seu sentido mediante o marco característico do político. Esse é o pressuposto que justifica a ênfase na conceitualização do que é a essência do político.

Neste primeiro capítulo ${ }^{37}$, explica que raramente existe uma definição clara do que seja político, sendo que na maioria dos casos o termo é equiparado ao que se quer expressar por "estatal", de modo que "[...] o Estado surge então como algo político, o político, porém, como algo estatal; evidentemente um círculo que não satisfaz" ${ }^{\prime 38}$. O objetivo aqui é diferenciá-los.

Como critério do que é político, o autor, já no capítulo segundo ${ }^{39}$, expressa que a identificação conceitual do que é político somente pode ser alcançada com a descoberta e com a utilização das categorias que sejam especificamente políticas. Com isso busca diferenciar - por meio das distinções últimas - o que é político daquilo que é moral, estético ou econômico. Se a distinção última da moral é o bom e o mau; se a do estético é o belo e o feio e se a do econômico é o útil e o

35 SCHMITT, O Conceito do Político, 1992, p. 43.

36 O Conceito do Político teve três edições. A primeira em 1927, a segunda em 1932, a terceira em 1933 e uma reedição em 1963 da edição de 1932. Para compreender melhor as motivações de Schmitt no que concerne às alterações feitas de edição para edição, bem como para compreender porque a edição de 1932 foi republicada, e não a edição de 1933, ver MEIER, Carl Schmitt and Leo Strauss: the hidden dialogue, 1995, p. 6-7, especialmente a nota $\mathrm{n}^{\mathrm{o}} 5$.

37 Intitulado "Estatal e político". SCHMITT, O Conceito do Político, 1992, p. 43-50.

38 SCHMITT, O Conceito do Político, 1992, p. 44.

39 Intitulado "A distinção amigo-inimigo, critério do político". SCHMITT, O Conceito do Político, 1992, p. 51-53. 
prejudicial (ou o rentável e o não rentável); a distinção última do político é a discriminação entre amigo e inimigo, pois ela não é derivável de outros critérios, sendo independente das demais contraposições morais, estéticas ou econômicas.

É bom que se diga - para evitar confusões - algo que está expresso na obra: “[...] o inimigo político não precisa ser moralmente mau, não precisa ser esteticamente feio; nem tem que surgir como concorrente econômico" ${ }^{\prime 40}$. Logo, não se trata de uma questão passional ou preconceituosa. $\mathrm{O}$ aspecto relevante para a determinação do que é o inimigo político é a real possibilidade de que exista uma divergência que possa levar ao conflito físico:

[...] ele é justamente o outro, o estrangeiro, bastando à sua essência que, num sentido particularmente intensivo, ele seja existencialmente algo outro e estrangeiro, de modo que, no caso extremo, há possibilidade de conflitos com ele, os quais não podem ser decididos mediante uma normatização geral previamente estipulada, nem pelo veredicto de um terceiro "desinteressado", e, portanto, "imparcial". [...] O caso extremo de conflito só pode ser decidido pelos próprios interessados; a saber, cada um deles tem que decidir por si mesmo se a alteridade do estrangeiro, no caso concreto do conflito presente, representa a negação da sua própria forma de existência, devendo, portanto, ser repelido e combatido" ${ }^{\prime 1}$.

Em seguida ${ }^{42}$, demonstrando como identifica-se o inimigo político, na teoria de Schmitt o inimigo não é apenas o concorrente, como quer o liberalismo. Ele não deve ser

\footnotetext{
${ }^{40}$ SCHMITT, O Conceito do Político, 1992, p. 52.

${ }^{41}$ SCHMITT, O Conceito do Político, 1992, p. 52.

${ }^{42}$ Capítulo 3, intitulado "A guerra como o fenômeno da hostilidade". SCHMITT, O Conceito do Político, 1992, p. 54-62.
} 
O Conceito do Político e a Possibilidade da Filosofia Política na Modernidade...

tomado no sentido metafórico, mas no sentido existencial. Ele não é o adversário, mas é o

[...] conjunto de homens, pelo menos eventualmente, isto é, segundo a possibilidade real, combatente, que se contrapõe a um conjunto semelhante. Inimigo é apenas o inimigo público [...]. Inimigo é o hostis, e não inimicius no sentido lato ${ }^{43}$.

O ponto importante, aqui, é a diferenciação entre o inimigo público e o privado. Ele não nega que se deva "amar os inimigos", mas enquanto inimigos privados ${ }^{44}$. $\mathrm{O}$ inimigo político é aquele que afronta um modo de vida e, assim sendo, deve ser combatido politicamente.

Todos os conceitos políticos, para Schmitt, têm um sentido "polêmico", de modo que sempre há uma contraposição (e por isso o uso do critério amigo-inimigo). Eles seriam incompreensíveis se não houvesse tal contraposição. Contraposição que, como dito, para ser política, precisa do risco de resultar em guerra (aniquilamento físico). Mas atente-se,

[...] a definição aqui fornecida do político não é belicista nem militarista, imperialista ou pacifista [...]. A guerra não é, absolutamente, fim e objetivo, sequer conteúdo da política, porém é pressuposto sempre presente como possibilidade real, a determinar o agir e o pensar humanos de modo peculiar, efetuando assim um comportamento especificamente político. ${ }^{45}$

43 SCHMITT, O Conceito do Político, 1992, p. 55.

${ }^{44}$ Convém esclarecer a passagem: "A muito citada passagem 'Amai vossos inimigos' (Mateus 5, 44; Lucas 6, 27) [...] não se fala do inimigo político. Mesmo no combate milenar entre cristandade e islamismo, jamais ocorreu a um cristão a ideia de que por amor aos sarracenos ou aos turcos se deveria entregar a Europa ao Islã em vez de defendê-la. O inimigo no sentido político não precisa ser odiado pessoalmente, e somente na esfera privada tem sentido amar seu 'inimigo'". SCHMITT, O Conceito do Político, 1992, p. 55.

45 SCHMITT, O Conceito do Político, 1992, p. 59-60. 
Então a guerra, como mostra da hostilidade política, é o que delimita e conceitua o âmbito político - o que não significa, como expressamente rechaçado por Schmitt, que se devam fazer guerras. Significa, isso sim, que no mundo da política temos que ter consciência de que existe essa possibilidade, que existe o risco dela ocorrer na defesa de sua própria forma de existência social. Mais do que isso, em seguida ${ }^{46} \mathrm{Schmitt}$ explica que toda e qualquer divergência - seja religiosa, moral, econômica, étnica etc. - transforma-se numa contraposição política se tiver força suficiente para agrupar os homens em amigos e inimigos.

Explica, ainda, que o Estado não é apenas mais uma associação, ao lado de várias outras que subsistem dentro do Estado (tese que ele chama de "pluralista"). Essa tese, para ele, não consegue enxergar o papel do político, pois nem sequer aceitaria que as várias sociedades (agremiações) que compõem o Estado poderiam se unir federativamente em um ente unitário, o Estado. Ao Estado cabe, então, por ser a unidade essencialmente política, o jus belli, ou seja, “[...] a possibilidade real de, num dado caso, determinar, em virtude de sua própria decisão, o inimigo, e combatê-lo" ${ }^{\prime 4}$. Ao jus belli, corresponde uma dupla possibilidade, tanto exigir dos seus cidadãos que morram e matem pela comunidade política, quanto matar os cidadãos da comunidade inimiga. Entretanto, a função do Estado não é causar a guerra, e sim estabelecer e manter a normalidade, pois apenas na normalidade é que as normas poderão ter asseguradas a sua validade: a

\footnotetext{
${ }^{46}$ Capítulo 4, intitulado "O Estado, como forma da unidade política, questionado pelo pluralismo". SCHMITT, O Conceito do Político, 1992, p. 63-70.

47 O Capítulo 5, intitulado "A decisão sobre a guerra e a designação do inimigo", busca demonstrar isso. SCHMITT, O Conceito do Político, 1992, p. 71-79.
} 
O Conceito do Político e a Possibilidade da Filosofia Política na Modernidade...

norma pressupõe uma normalidade. Esse objetivo do Estado é bem claro:

A função bem desempenhada de um Estado normal consiste porém sobretudo em produzir no interior do Estado e de seu território uma satisfação completa, estabelecer "tranquilidade, segurança e ordem", e assim criar a situação normal que é pressuposição para que as normas jurídicas possam valer, porque cada norma pressupõe uma situação normal e nenhuma norma pode ter validade para uma situação que frente a ela é totalmente anormal. ${ }^{48}$

Agora, se o político pressupõe o inimigo, “[...] o mundo não é uma unidade política e sim um pluriversum político"49, pois necessariamente existirão outros estados (por isso "pluriverso" e não "universo"). Contudo, a humanidade, enquanto tal, certamente não pode fazer guerras, uma vez que não possui inimigos. Toda guerra feita em nome da humanidade, da universalidade, será um modo para que uma das partes abuse do seu inimigo, ao argumento de que não existe humanidade no lado contrário. É uma “[...] utilização altamente política de nome apolítico" ${ }^{50}$. Poderíamos dizer, inclusive, que o conceito de paz pressupõe a existência da guerra (ou, pelo menos, e eis o ponto importante do argumento, o seu risco real). No momento que se negar o conceito de guerra, automaticamente se negará o de paz.

Finalmente, ainda é abordado por Schmitt "o fundamento antropológico das teorias políticas" ${ }^{21}$. Segundo ele,

48 SCHMITT, O Conceito do Político, 1992, p. 72. Schmitt ainda denuncia o descabimento de uma guerra feita para "que nunca mais haja guerra". Para ele a única justificação da guerra é a política, o combate ao inimigo (p. 75).

49 Título do Capítulo 6. SCHMITT, O Conceito do Político, 1992, p. 80-84.

${ }^{50}$ SCHMITT, O Conceito do Político, 1992, p. 81.

${ }^{51}$ Título do Capítulo 7. SCHMITT, O Conceito do Político, 1992, p. 85-95. 
o questionamento antropológico importante não é aquele que pergunta se o homem é "bom por natureza" ou se é "mau por natureza" (este questionamento seria "ingênuo"). O questionamento importante acerca do fundamento de toda e qualquer teoria política é "a concepção problemática ou não-problemática do homem" ${ }^{52}$. Este é o pressuposto para todas as outras ponderações políticas. Seu objetivo no capítulo é demonstrar como todos os pensadores realmente políticos colocam o homem como um "ser perigoso":

[...] resta portanto a constatação estranha, e para muitos seguramente inquietante, de que todas as autênticas teorias políticas pressupõem o homem como "mau", isto é, consideram-no como um ser dinâmico e "perigoso" e jamais não-problemático. ${ }^{53}[\ldots]$ [isso porque] já que a esfera do político em última análise é determinada pela possibilidade real de um inimigo, as noções e os raciocínios políticos não podem satisfatoriamente tomar um "otimismo" antropológico como ponto de partida. Caso contrário, junto com a possibilidade do inimigo seria abolida também toda lógica política. ${ }^{54}$

Finalizando ${ }^{55}$, Schmitt volta a tratar o projeto moderno como despolitizador. Aliás, não nega que os modernos tenham feito política - certamente fazem, especialmente para defender sua concepção. Contudo a consequência de suas ideias é a despolitização,

[...] [p]ois a negação do político que está contida em todo e qualquer individualismo consequente conduz sem dúvida

52 SCHMITT, O Conceito do Político, 1992, p. 85-87.

53 SCHMITT, O Conceito do Político, 1992, p. 88.

${ }_{54}$ SCHMITT, O Conceito do Político, 1992, p. 91. Finaliza dizendo que a incapacidade para fazer essa diferenciação, bem como pensar que o homem é "bom por natureza" foi o sintoma de uma sociedade em declínio (p. 94).

55 Capítulo 8: "A despolitização pela polaridade de ética e economia". SCHMITT, O Conceito do Político, 1992, p. 96-105. 
a uma práxis política da desconfiança frente a todos os poderes políticos e formas de Estado imagináveis, porém jamais conduz a uma própria e positiva teoria do Estado e da política. Por conseguinte, existe uma política liberal enquanto oposição polêmica frente a restrições, estatais, eclesiásticas ou outras, da liberdade individual, enquanto política de comércio, política eclesiástica e educacional, política cultural, mas nenhuma política liberal pura e simplesmente, e sim apenas e sempre uma critica liberal da política. ${ }^{56}$

Se a unidade política pode exigir sacrifícios em determinados casos, para o projeto liberal individualista despolitizador moderno, tal pretensão jamais será alcançada, nem fundamentada ${ }^{57}$. A modernidade despolitiza conceitos políticos (como estratégia de sua política) e acaba por submeter o Estado e a política a uma moral individualista ${ }^{58}$. Assim, a "[...] economia se tornou algo de político e com isso se tornou o 'destino'" 59 . E essa polaridade moderna entre ética e economia, negando e se sobrepondo à política, esse

[...] sistema supostamente apolítico e aparentemente até antipolítico, ou serve aos agrupamentos de amigo e inimigo já estabelecidos, ou conduz a novos agrupamentos destes e não consegue espaçar à consequência do político. ${ }^{60}$

Enfim, não há como não existir o político. Mas há um discurso que busca negá-lo. Por isso o livro: para estabelecer a posição do político, polemizando com aqueles que o negam.

Ademais, certamente $O$ Conceito do Político não está desconectado da produção intelectual de Schmitt. Pelo contrário,

\footnotetext{
56 SCHMITT, O Conceito do Político, 1992, p. 97.

57 SCHMITT, O Conceito do Político, 1992, p. 98.

58 SCHMITT, O Conceito do Político, 1992, p. 98-99.

59 SCHMITT, O Conceito do Político, 1992, p. 104.

${ }^{60}$ SCHMITT, O Conceito do Político, 1992, p. 105.
} 
ele se coaduna com suas principais ideias ${ }^{61}$. Para melhor compreender os argumentos de Schmitt analisaremos, as ideias de identidade e representação, e de responsabilidade ${ }^{62}$, que completam as ideias de soberania e de decisão ${ }^{63}$, para chegarmos à conclusão de que, em Schmitt, a política se dá externamente, nas relações com aqueles que ameaçam o modo de vida do povo, e não internamente, na comunidade.

Em Schmitt todo Estado baseia-se no princípio da identidade e no princípio da representação ${ }^{64}$. Por tal motivo que é importante bem compreender o argumento schmittiano de "amigo" e de "inimigo", uma vez que o conceito democrático de igualdade é um conceito político e faz referência à possibilidade de diferenciação, de modo que nenhuma comunidade política se funda na igualdade humana de modo genérico. A igualdade humana seria um postulado genérico absoluto que se mostra insuficiente para a fundação de uma comunidade política $^{65}$ : o conceito central da democracia é o povo, não a humanidade. Se a democracia quiser ser uma forma política, só existe uma democracia popular, e não uma democracia humanitária. $\mathrm{O}$ argumento e a diferenciação entre o plano da

${ }^{61}$ STRAUSS, Notes on Carl Schmitt, The Concept of the Political, 1995, p. 91: "This thesis [the concept of the state presupposes the concept of the political], with which the investigation of the political is begun, must be understood in accordance with Schmitt's own general principles of understanding."

${ }^{62}$ Conforme apresentadas em: BARZOTTO, Luis Fernando. Filosofia e Constituição. In: MARTINS, Ives Gandra da Silva; MENDES, Gilmar Ferreira; NASCIMENTO, Carlos Valder (Coord.). Tratado de Direito Constitucional. v. 1. São Paulo: Saraiva, 2010. p. 617-653.

${ }^{63}$ NOWAK, Piotr. Carl Schmitt and his critic. In: ARMADA, Pawel; GÓRNISIEWICZ, Arkadiusz (Ed.). Modernity and What Has Been Lost: Considerations on the Legacy of Leo Strauss. South Bend: St. Augustine Press; Krakow: The Jagiellonian University Press, 2011. p. 125-127.

${ }^{64}$ BARZOTTO, Filosofia e Constituição, 2010, p. 624.

${ }^{65}$ BARZOTTO, Filosofia e Constituição, 2010, p. 626. 
O Conceito do Político e a Possibilidade da Filosofia Política na Modernidade...

ética e da política fica claro e nos recorda aquela passagem já citada anteriormente que diferencia o inimigo público do privado:

[...] a amizade entre todos os homens está no plano da ética, e entre os homens como tais não pode haver inimizade. A amizade política é sempre mais restrita do que a amizade ‘humana' [...]. Se 'todo homem é próximo' [...], nem todo homem é concidadão. ${ }^{66}$

Desde a filosofia política clássica, a comunidade política é um grupo determinado (polis), e não todos os seres humanos.

Isso porque, no âmbito político, em vista do princípio da representação, o representante tem dever de responsabilidade perante aqueles que representa. Ele assume o risco político: representante político é o ente capaz de tomar decisões em nome daqueles que representa e de responder por essas decisões perante os representados ${ }^{67}$.

Schmitt dá ênfase à decisão (entendida não como mera escolha, mas como resposta a uma questão que une razão e vontade ${ }^{68}$ ) e daí provém sua teoria do estado de exceção e seu célebre conceito de soberano ${ }^{69}$. Na situação que foge à normalidade instituída pelo âmbito político, o soberano é aquele que suspende o direito em nome do direito. Para Barzotto "[...] a ilusão liberal [a que a crítica de Schmitt se dirige] consiste em pensar que toda a atividade política pode ser enquadrada

${ }_{66}$ BARZOTTO, Filosofia e Constituição, 2010, p. 626.

67 BARZOTTO, Filosofia e Constituição, 2010, p. 627-629.

${ }^{68}$ BARZOTTO, Filosofia e Constituição, 2010, p. 641.

69 "Soberano é quem decide sobre o estado de exceção". SCHMITT apud BARZOTTO,

Filosofia e Constituição, 2010, p. 643. 
normativamente, quer dizer, o liberalismo quer tornar supérflua a decisão, o que significa abolir a política"70.

Enfim, em Schmitt o critério da instituição da comunidade, o critério para a existência de um povo, é uma decisão concorde acerca dos inimigos do seu modo de vida. Logo a política, enquanto relação com o inimigo, só é feita externamente à comunidade.

\section{Diálogo de Schmitt e Strauss e a Pergunta de Vida e Morte}

Se a abertura do livro de Schmitt é instigante, a abertura do texto de Strauss também o é: "[t]he treatise by Schmitt serves the question of the 'order of the human things', that is, the question of the state" ${ }^{\prime 71}$. A relação entre o que Schmitt considera o "político" e o que Strauss considera a "questão do Estado" é uma das sutilezas que torna o seu texto tão interessante. A “ordem das coisas humanas" deve ser compreendida em contraposição com as "coisas divinas" ou com as "coisas da natureza". A filosofia política trata justamente das "coisas humanas"72. Strauss está a dizer, já de início, que a preocupação de Schmitt, no fundo, não é apenas criticar o liberalismo, mas é, sem perceber, fazer filosofia política ${ }^{73}$ :

${ }^{70}$ BARZOTTO, Filosofia e Constituição, 2010, p. 643.

${ }^{71}$ STRAUSS, Notes on Carl Schmitt, The Concept of the Political, 1995, p. 91.

72 STRAUSS, On Classical Political Philosophy, 1988, p. 92.

${ }^{73}$ Sua perspicácia é tamanha que se diz que o próprio Schmitt a teria reconhecido. Meier, na abertura da edição norte-americana de sua obra conta que, após a publicação alemã do livro que trata do diálogo oculto mantido entre Schmitt e Strauss, um ex-aluno de Schmitt procurou-lhe para contar que seu antigo professor, após ler os comentários de Strauss ao seu O Conceito do Político teria dito: "You've got to read that. He saw through me and X-rayed me as nobody else has". MEIER, Carl Schmitt and Leo Strauss: the hidden dialogue, 1995, p. XVII. 
O Conceito do Político e a Possibilidade da Filosofia Política na Modernidade...

Thus what ultimately matters to Schmitt is not the battle against liberalism. For that very reason the affirmation of the political as such is not his last word. His last word is "the order of the human things" ${ }^{\prime 74}$.

Assim, para Strauss, a tese de Schmitt é colocada sob um foco ambíguo ${ }^{75}$. Tanto para os Zuckert ${ }^{76}$, quanto para Shell ${ }^{77}$ é esta ambiguidade que Strauss busca tornar clara, por meio de uma melhor compreensão das consequências do pensamento de Hobbes ${ }^{78}$.

Desse modo é que Strauss busca mostrar que a crítica ao liberalismo lançada por Schmitt é incompleta. Isso porque ele estaria inserido no mundo liberal ao criticá-lo, não enxergando para além. Para Strauss, uma crítica ao liberalismo da modernidade somente seria possível quando se fosse além do liberalismo, quando o seu horizonte fosse superado ${ }^{79}$. Nesse sentido, com o seu retorno aos clássicos, Strauss estaria em vantagem sob Schmitt ${ }^{80}$.

Assim pode-se dizer que Strauss concordava com o fato de que o liberalismo precisava ser criticado, o que não

${ }^{74}$ STRAUSS, Notes on Carl Schmitt, The Concept of the Political, 1995, p. 118 (grifos do autor).

${ }^{75}$ STRAUSS, Three letters to Carl Schmitt, 1995, p. 125.

76 "Schmitt's affirmation of the political contained a certain ambiguity which Strauss worked hard in his essay to expose." ZUCKERT; ZUCKERT, The truth about Leo Strauss: political philosophy and American democracy, 2008, p. 188.

77 “This tension, if not contraction, places Schmitt's thesis - that the state is founded in the political - in an immediately ambiguous light". SHELL, Taking Evil Seriously: Schmitt's "Concept of the Political" and Strauss's "True Politics", 1994, p. 187.

${ }^{78}$ HERRERO, Montserrat. La posición de lo Político: Schmitt frente a Strauss. In: RODRIGUEZ DE GRZONA, Mirtha (Comp.). Estudios sobre Leo Strauss. Mendoza: Centro de Estudios de Filosofia Clasica, 2010. p. 115. Este artigo oferece uma defesa de Schmitt frente às críticas de Strauss.

79 STRAUSS, Notes on Carl Schmitt, The Concept of the Political, 1995, p. 119.

${ }^{80}$ ZUCKERT; ZUCKERT, The truth about Leo Strauss: political philosophy and American democracy, 2008, p. 187. 
significa dizer que ele concordasse com os termos nos quais essa crítica foi feita por Schmitt: ambos, cada um a seu modo, buscam proteger a política, contra um projeto que, se não nega completamente a política, pelo menos a esconde ${ }^{81}$.

Os Zuckert resumem a complexa posição de Schmitt em três proposições: o liberalismo falhou; as causas de sua falha podem ser encontradas na sua negação do político e; a essência do político é a distinção entre amigos e inimigos ${ }^{82}$. Strauss concordaria de modo geral com as duas primeiras proposições, mas discordaria da terceira, pois este é um modo moderno - e, portanto, condizente com o pensamento liberal - de compreender a política ${ }^{83}$.

Se é correto dizer que Strauss e Schmitt veem na ideia de política uma boa resposta ao liberalismo, é preciso notar que eles discordam fundamentalmente sobre o que isso significa ${ }^{84}$. Para Strauss, seguindo a linha da filosofia política clássica, política não é a distinção entre amigos e inimigos, mas é a percepção de que o homem é um animal com sociabilidade e com racionalidade naturais ${ }^{85}$. Logo, a reafirmação do político não poderia depender de uma decisão acerca do inimigo, pois esta depende de um horizonte filosófico que transcende o pensamento político moderno de $\mathrm{Hobbes}^{86}$, no qual Schmitt estava inserido.

${ }^{81}$ STRAUSS, Notes on Carl Schmitt, The Concept of the Political, 1995, p. 92.

82 ZUCKERT; ZUCKERT, The truth about Leo Strauss: political philosophy and American democracy, 2008, p. 189.

83 ZUCKERT; ZUCKERT, The truth about Leo Strauss: political philosophy and American democracy, 2008, p. 189-194.

${ }^{84}$ SHELL, Taking Evil Seriously: Schmitt's "Concept of the Political" and Strauss's "True Politics", 1994, p. 185.

85 ZUCKERT; ZUCKERT, The truth about Leo Strauss: political philosophy and American democracy, 2008, p. 192-193.

${ }^{86}$ MORGADO, Miguel. Introdução do Tradutor. In: STRAUSS, Leo. Direito Natural e História. Tradução de Miguel Morgado. Lisboa: Edições 70, 2009. p. XXVII. 
Assim é que ele, ao lançar sua resenha sobre o livro de Schmitt, parece-nos, tem três objetivos ${ }^{87}$ : mostrar que Schmitt está fazendo filosofia política (mesmo que sem perceber); mostrar que, no fundo, para que a crítica ao liberalismo tenha sentido, é preciso compreender o texto de Schmitt como uma crítica à ideia de civilização fundada no liberalismo hobbesiano e; concluir que o homem é não é mau por natureza, mas sim "perigoso" por natureza.

\subsection{Schmitt e a Filosofia Política}

Vimos que, para Strauss, a principal preocupação de Schmitt seria fazer aquilo que o próprio Strauss chama de filosofia política. Para tanto, Strauss, após dizer que o livro de Schmitt trata da "ordem das coisas humanas", inicia seus comentários situando o leitor, demonstrando como é preciso compreender quem (ou qual ideia) Schmitt está criticando. Ou, em termos schmittianos, com quem ele está polemizando: explica que na visão de Schmitt o projeto moderno teria como objetivo autêntico a despolitização e a neutralização $0^{88}$. Schmitt possui, portanto, uma opinião, a qual aspira a ser verdadeira, contraposta a outra opinião, a qual, por sua vez, também aspira a ser verdadeira. Esse embate de opiniões em busca do conhecimento é filosofia política ${ }^{89}$. Ou seja, há entre Schmitt e Strauss diferentes pontos de vista acerca do problema político. Um tem uma visão política,

\footnotetext{
${ }^{87}$ Três objetivos aqui identificados conforme a divisão da resenha de Strauss em três capítulos.

88 STRAUSS, Notes on Carl Schmitt, The Concept of the Political, 1995, p. 92.

${ }^{89}$ STRAUSS, What is Political Philosophy?, 1988, p. 11-12.
} 
baseada na polêmica, no embate; enquanto que o outro tem uma visão filosófica, que almeja (mas nunca conseguirá de modo completo) acabar com a polêmica, na medida em que, sendo a filosofia política a elevação ao conhecimento, acabar-se-ia com a polêmica ${ }^{90}$.

Expõe Strauss, contudo, que na verdade o pensamento moderno não objetiva a despolitização: ela não nega a política, mas apenas a esconde. Então o liberalismo não matou o âmbito político, mas matou a compreensão acerca deste âmbito. Para ele é preciso que a cortina de fumaça que existe acerca da compreensão do político, lançada pelo liberalismo, seja desfeita para que então se possa voltar a discutir o que é realmente importante, não o conceito do político, que é utilizado de Schmitt apenas para chamar a atenção para o problema, mas a ordem das coisas humanas, a questão do estado, ou seja, a filosofia política:

Schmitt's task is determined by the fact that liberalism has failed. The circumstances of this failure are as follows: Liberalism negated the political; yet liberalism has not thereby eliminated the political from the face of the earth but only has hidden it; liberalism has led the politics' being engaged in by means of an antipolitical mode of discourse. Liberalism has thus killed not the political but only understanding of the political, sincerity regarding the political. In order to remove the smokescreen over reality that liberalism produces, the political must be made apparent as such and as simply undeniable. The political must first be brought out of the concealment into which liberalism has cast it, so that the question of the state can be seriously put. ${ }^{91}$

\footnotetext{
${ }^{90}$ MEIER, Carl Schmitt and Leo Strauss: the hidden dialogue, 1995, p. 5.

${ }^{91}$ STRAUSS, Notes on Carl Schmitt, The Concept of the Political, 1995, p. 92.
} 
Strauss está dizendo que a política não acabou - e não acabará, pois é da natureza humana buscar o melhor regime para a comunidade política. A política nunca deixará de existir, mas sua compreensão pode ser escondida (assim como era antes do surgimento da filosofia política, na Grécia Antiga). Lutar contra a perda dessa compreensão é o objetivo de Strauss, que vê no escondimento das questões sobre a ordem das coisas humanas a negação da filosofia política que é feita pelo pensamento moderno. Compreender o que é o político e criticar o liberalismo é apenas um passo para que a discussão verdadeira seja colocada.

Tanto para ele quanto para Schmitt, o que importa é resgatar a possibilidade e a necessidade da filosofia política ${ }^{92}$, só que, para Strauss, Schmitt faz filosofia política, mas sem perceber, na medida em que se limita ao embate, e não ao

\subsection{A Crítica ao Liberalismo como uma Correta Compreensão de Hobbes: a Crítica à Ideia de Civilização e a Periculosidade Natural do Homem}

Já falando sobre o critério do político (diferenciação entre amigo e inimigo), Strauss afirma que, em que pese Schmitt colocar o âmbito político como autônomo (portanto "ao lado", equiparado a outros âmbitos, tais como o moral, o estético e o econômico), na verdade ele apresenta uma tese que coloca o político acima dos demais domínios:

But the possibility of war does not merely constitute the political as such; war is not merely "the most extreme political measure"; war is the dire emergency not merely

92 STRAUSS, Three letters to Carl Schmitt, 1995. 
within an "autonomous" region - the region of the political - but for man simply, because war has and retains a "relationship to the real possibility of physical killing"; this orientation, which is constitutive of the political, shows that the political is fundamental and not a "relatively independent domain" alongside others. The political is the "authoritative" ${ }^{93}$.

Strauss mostra como a compreensão do político em Schmitt é, no fundo, uma crítica à noção moderna de cultura ${ }^{94}$. A concepção moderna de cultura, com sua base em Hobbes, é o status civilis, é a fundação do conceito de civilização ${ }^{95}$, pois o status naturalis é o status belli ${ }^{96}$. Contudo, para Schmitt, em sendo a posição do político a possibilidade de guerra, é o status naturalis (e não o civilis) que é o status genuinamente político $^{97}$ :

The political, which Schmitt brings to bear as fundamental, is in Strauss's interpretation neither more nor less than the "state of nature" that the "philosophy of culture" has erased from memory. ${ }^{98}[\ldots]$ He $[$ Strauss] renders the oppo-

${ }_{93}$ STRAUSS, Notes on Carl Schmitt, The Concept of the Political, 1995, p. 97.

${ }^{4}$ STRAUSS, Notes on Carl Schmitt, The Concept of the Political, 1995, p. 94-95: "What is hereby said is that the understanding of the political implies a fundamental critique of at least the prevailing concept of culture."

95 STRAUSS, Notes on Carl Schmitt, The Concept of the Political, 1995, p. 100: "Hobbes $[\ldots]$ is the author of the ideal of civilization. By this very fact he is the founder of liberalism."

${ }^{96}$ STRAUSS, Notes on Carl Schmitt, The Concept of the Political, 1995, p. 98: "Hobbes understood the status civilis in the sense of the specifically modern concept of culture [...] as the opposite of the status naturalis; the status civilis is the presupposition of every culture in the narrow sense (i.e. every nurture of the arts and sciences) and is itself already based on a particular culture, namely, on a disciplining of the human will [...] Hobbes describes the status naturalis as the status belli".

${ }^{97}$ STRAUSS, Notes on Carl Schmitt, The Concept of the Political, 1995, p. 98-99: “In Schmitt's terminology this statement means that the status naturalis is the genuinely political status".

${ }^{98}$ MEIER, Carl Schmitt and Leo Strauss: the hidden dialogue, 1995, p. 32. 
sition between the position and the negation of the political concrete by describing it as the conflict between the "position of the political" and the "position of civilization". He shows that the individualistic principles that cause Hobbes to negate the political in Schmitt's sense are the very same principles that, historically developed, finally underlie the project of the completely depoliticized and neutralized "unity of the world", against which Schmitt seeks to defend the "inescapability of the political. ${ }^{99}$

Ou seja, Hobbes usa o status civilis (e não o status naturalis) para caracterizar a cultura. É o status civilis que disciplina a vontade humana do status naturalis. Em Hobbes, portanto, segundo a leitura de Strauss, o estado de guerra (que Schmitt pretende como político) existia antes da cultura disciplinar os homens no status naturalis. Eis a crítica de Strauss: enquanto Schmitt quer dizer que o status naturalis (onde pode haver o risco sério de guerra) é o político, Hobbes diz que é no status civilis, onde não há essa possibilidade de guerra, que existe a cultura e a política.

A partir de então Strauss passa a mostrar algumas diferenças entre o que ele interpreta de Hobbes e como tais interpretações vão contra a ideia de política presente em O Conceito do Político. Dessa diferença de leitura retira-se talvez a mais contundente crítica de Strauss: enquanto Schmitt, na sua primeira edição em 1927 descrevia Hobbes como, de longe, o maior e talvez o único pensador político verdadeiramente sistemático ${ }^{100}$, passou a dizer, na edição de 1932, que Hobbes era apenas um grande pensador político e verda-

\footnotetext{
${ }^{99}$ MEIER, Carl Schmitt and Leo Strauss: the hidden dialogue, 1995, p. 34.

${ }^{100}$ STRAUSS, Notes on Carl Schmitt, The Concept of the Political, 1995, p. 102, nota de rodapé: "In the first edition of this treatise Schmitt had described Hobbes as 'by far the greatest and perhaps the sole truly systematic political thinker"'.
} 
deiramente sistemático ${ }^{101}$; mas, para Strauss, Hobbes é - em termos schmittianos do conceito de político - "the antipolitical thinker"102: para Strauss, caso aplicada a teoria de Schmitt, Hobbes seria justamente o fundador daquilo que Schmitt está a criticar. Schmitt se limita ao embate, mas não percebe quem é o seu principal rival ${ }^{103}$. Interessante notar que Schmitt responde a esta crítica na edição de 1933, deixando de chamar Hobbes de pensador político ${ }^{104}$, referindo-se a ele apenas como grande pensador verdadeiramente sistemático, bem como expressamente se afastando do pensamento de Hobbes em outras oportunidades ${ }^{105}$.

Hobbes seria o pensador "antipolítico", não apenas porque coloca a política dentro do status civilis, onde não há o risco de guerra, mas também porque a sua antropologia de ver o homem como "mau" é bastante diferente da de Schmitt que vê o homem como "perigoso"106. Há dois sentidos para a compreensão do que é essa antropologia do homem mau ${ }^{107}$.

\footnotetext{
${ }^{101}$ SCHMITT, O Conceito do Político, 1992, p. 92.

STRAUSS, Notes on Carl Schmitt, The Concept of the Political, 1995, p. 102, nota de rodapé: "Schmitt now speaks of Hobbes only as 'a great and truly systematic political thinker"'.

${ }^{102}$ STRAUSS, Notes on Carl Schmitt, The Concept of the Political, 1995, p. 102, nota de rodapé: "In truth Hobbes is the antipolitical thinker ('political understood in Schmitt's sense)". (grifo do autor).

${ }^{103}$ MEIER, Carl Schmitt and Leo Strauss: the hidden dialogue, 1995, p. 35.

${ }^{104}$ MEIER, Carl Schmitt and Leo Strauss: the hidden dialogue, 1995, p. 36: "How does Schmitt respond to this challenge? [...] with deletions and insertions that take Strauss's 'Notes' into account. In 1933, Hobbes has undergone metamorphosis from 'by far the greatest and perhaps the sole truly systematic political thinker' via 'a great and truly systematic thinker'".

${ }^{105}$ MEIER, Carl Schmitt and Leo Strauss: the hidden dialogue, 1995, p. 37, nota no 38 .

${ }^{106}$ NOWAK, Carl Schmitt and his critic, 2011, p. 133.

${ }^{107}$ SCHMITT enxerga a periculosidade do homem como o pecado original - tendo-se em vista sua teologia política (MEIER, Carl Schmitt and Leo Strauss: the hidden dialogue, 1995, p. 53). Hobbes, contudo, vê a maldade do homem como algo
} 
O Conceito do Político e a Possibilidade da Filosofia Política na Modernidade...

Uma delas - a hobbesiana - é ingênua, inocente ${ }^{108}$, tratando a maldade do homem em estado de natureza como sendo a maldade das bestas (uma maldade de instinto animal pela autopreservação). Assim, para Strauss, em Hobbes a maldade inocente do homem no estado de natureza deve ser combatida (pela instituição do estado civil), enquanto que para Schmitt a "maldade" do homem não é ingênua ou inocente, mas é uma maldade "perigosa". Na verdade, explica Strauss, Schmitt abomina a ideia de Hobbes (formulação que certamente não seria conscientemente aceita por Schmitt). Para Strauss, o objetivo de Schmitt seria justamente rechaçar a ideia liberal inaugurada por Hobbes, por meio de uma defesa do status naturalis, ou seja, por meio de uma defesa da natureza humana, contra a ideia de civilização: "Schmitt returns, contrary to liberalism, to its author, Hobbes, in order to strike at the root of liberalism in Hobbes's express negation of the state of nature" 109 .

\section{Considerações Finais}

É a periculosidade do homem (e não a maldade ingênua) que leva Schmitt a utilizar a distinção entre amigo e inimigo como o critério do político. Ao afirmar a posição do político, ele busca combater a ideia de civilização, a qual nos levaria a um mundo de entretenimento, onde a pergunta de vida e morte nunca é colocada e onde, consequentemente, não

inocente justamente porque não tem no seu horizonte a noção do pecado original (ibidem, p. 57): "Hobbes had to understand evil as innocent 'evil' because he denied sin" (STRAUSS, Notes on Carl Schmitt, The Concept of the Political, 1995, p. 109).

${ }^{108}$ STRAUSS, Notes on Carl Schmitt, The Concept of the Political, 1995, p. 109.

${ }^{109}$ STRAUSS, Notes on Carl Schmitt, The Concept of the Political, 1995, p. 101-102. 
haveria política ${ }^{110}$. Sem a pergunta que separa os homens em amigos e inimigos, não há mais política.

Contudo, é justamente aqui que reside a discordância mais clara entre Schmitt e Strauss. Enquanto que para um a pergunta de vida e morte divide os homens em amigos e inimigos, fundando a política; para o outro, o questionamento fundamental (e a compreensão das alternativas fundamentais), longe de dividir os homens, é o que funda a filosofia política. Enquanto que Schmitt simpatiza com uma deficiência humana (a necessidade de dominação, já que o homem é perigoso) ${ }^{111}$; Strauss simpatiza com a virtude, com a busca da transformação das opiniões em conhecimento dentro da comunidade política ${ }^{112}$. Para Strauss, a política é uma parte do todo que não se fecha no todo, pois seus elementos naturais, as opiniões, apontam para algo que transcende a política ${ }^{113}$.

Mas, se aceitarmos a utilização do termo "periculosidade", não como o risco de dividir os homens em amigos e inimigos, mas como o questionamento fundamental da ordem das coisas humanas, como o questionamento acerca do certo e do errado, podemos colocá-la como a fundação da filosofia política: o homem é perigoso porque questiona e esse questionamento se dá internamente (na Polis), fazendo política - diria Strauss - e não externamente, como pensava Schmitt.

\footnotetext{
${ }^{110}$ STRAUSS, Notes on Carl Schmitt, The Concept of the Political, 1995, p. 111-112.

${ }^{111}$ STRAUSS, Notes on Carl Schmitt, The Concept of the Political, 1995, p. 110-111: "Schmitt speaks with an unmistakable sympathy of the 'evil' [...]. This sympathy, however, is nothing other than admiration of animal power; [...] what is admired is not an excellence but a deficiency, a need (namely a need of dominion)."

${ }^{112}$ STRAUSS, What is Political Philosophy?, 1988, p. 11-12.

${ }^{113}$ MORGADO, Introdução do Tradutor, 2009, p. XXVIII.
} 
O Conceito do Político e a Possibilidade da Filosofia Política na Modernidade...

Na sua principal obra, Strauss diz que o surgimento do questionamento (acerca do direito natural) é o surgimento da filosofia política ${ }^{114}$. É com a pergunta de Sócrates, questionando a identificação que havia do bem com o ancestral que surge a filosofia política. Sócrates é a verdadeira e profunda periculosidade do homem, o questionamento fundamental, e consequentemente a compreensão das alternativas fundamentais: "Sócrates, diz-se, foi o primeiro a fazer a filosofia descer dos céus e a forçá-la a investigar a vida e os usos, as coisas boas e más. Por outras palavras, diz-se que Sócrates foi o fundador da filosofia política"115. Strauss está a narrar o surgimento da ideia de direito natural, a descoberta do direito natural por meio do questionamento da autoridade do ancestral. Se aceitarmos Sócrates como o representante da procura do direito natural, podemos ilustrar a relação dessa procura com a autoridade da seguinte forma: numa comunidade governada por leis divinas é estritamente proibido submeter essas leis a uma discussão séria, isto é, a um exame crítico, na presença de jovens. Contudo, Sócrates, não apenas discute o direito natural - cuja descoberta pressupõe que se duvide do ancestral ou do divino - na presença de jovens, como faz dessa discussão o objeto da conversa que tem com esses jovens. Podemos dizer, então, que essa é a pergunta fundamental que institui o "debate de vida e morte", que institui a política, mas não no sentido de dividir os homens em amigos e inimigos, e sim no sentido de fazer o homem

${ }^{114}$ STRAUSS, Direito Natural e História, 2009, p. 71: “[...] a tomada de consciência desse problema [do problema do direito natural] não é mais antiga do que a ciência política; é sua coeva". No mesmo sentido está a sua explicação do que é filosofia política em What is Political Philosophy?, já referida.

${ }^{115}$ STRAUSS, Direito Natural e História, 2009, p. 105. 
cumprir sua natureza em busca da percepção das alternativas fundamentais, em busca do conhecimento e em busca da verdade.

A pergunta de vida e morte, o questionamento fundamental, a elevação das opiniões a conhecimento é a filosofia política, por isso é que, para Strauss, a preocupação de Schmitt é a ordem das coisas humanas (a filosofia política ${ }^{116}$ ). Ambos concordam na crítica à modernidade que busca neutralizar a verdadeira pergunta sobre a questão do Estado. Contudo, o acordo entre todos dentro de uma comunidade, pressuposto por Schmitt na medida em que o inimigo é externo à comunidade, só é possível por meio da unanimidade interna, por meio da fuga dos questionamentos fundamentais, por meio da negação da possibilidade da filosofia política. Quando a pergunta sobre o que é certo for colocada dentro da comunidade, ela instituirá internamente a divisão entre amigos e inimigos, o que para Schmitt é impensável. Para Strauss, entretanto, é justamente esse questionamento interno que é a natureza da política: ele ocorre dentro da comunidade. Para Strauss, o preço da fuga cometida por Schmitt, da negação da pergunta fundamental dentro da comunidade, é muito caro. Custa demais deixar para trás a natureza humana, pois

Agreement at all costs is possible only as agreement at the cost of the meaning of human life; for agreement at all costs is possible only if man has relinquishes asking the question of what is right; and if man relinquishes that question, he relinquishes being a man. But if he seriously asks the question of what is right, the quarrel will be ignited (in view of "the inextricable set of problems" this question entails), the life-and-death quarrel: the political - the grouping of

${ }^{116}$ E justamente por isso é que Strauss questiona a Teologia Política: é do questionamento, e não da obediência, que se chega ao conhecimento de como se deve viver. 
O Conceito do Político e a Possibilidade da Filosofia Política na Modernidade...

humanity into friends and enemies - owes its legitimation to the seriousness of the question of what is right. ${ }^{117}$

Ou seja, deixar para trás a pergunta acerca do certo e do errado é negar a natureza humana, e é acabar com a possibilidade da filosofia política. O acordo a todo custo só é possível ao custo do sentido da vida humana ${ }^{118}$, só é possível se deixarmos de nos questionar acerca do certo, negando a natureza humana. Contudo, se levantarmos com seriedade a questão acerca do certo, a discussão começará, a discussão "de vida e morte" começará e estaremos em uma comunidade verdadeiramente política.

A afirmação do político é a afirmação do estado de natureza, ou seja, é a afirmação da natureza humana. Sua consequência não é necessariamente a guerra, mas sim a renúncia da segurança do status quo. Ou seja, a percepção das contingências é a consequência de levantar seriamente a pergunta, é a consequência da periculosidade do ser humano:

The affirmation of the political is the affirmation of the state of nature. Schmitt opposes the affirmation of the state of nature to the Hobbesian negation of the state of nature. The state of nature is the status belli, pure and simple. Thus it appears that the affirmation of the state of nature can only be bellicose. That appearance fades away as soon as one has grasped what the return to the state of nature means for Schmitt. The affirmation of the state of nature does not mean the affirmation of war but "relinquishment of the security of the status quo". ${ }^{119}$

${ }^{117}$ STRAUSS, Notes on Carl Schmitt, The Concept of the Political, 1995, p. 113.

${ }^{118}$ Pode-se dizer que a observação de Strauss busca assentar o fato de que há discordâncias dentro da comunidade - que discordâncias são da natureza humana. Schmitt acreditava que o povo deveria ser unânime, uniforme.

${ }^{119}$ STRAUSS, Notes on Carl Schmitt, The Concept of the Political, 1995, p. 115. 
Precisamos ter consciência dessa realidade humana e de suas contingências quando tratamos dos temas de política. As tentativas históricas de negar, ou de jogar uma "nuvem de fumaça" sobre essa natureza perigosa e questionadora do homem dentro da sua própria comunidade acabaram dando a humanidade argumentos para as maiores atrocidades. A nossa consciência da realidade humana é que será o limitador dos abusos da própria humanidade, caso contrário, sempre se poderá utilizar a luta pela humanidade, a guerra pela paz, como argumento retórico para a desumanização dos adversários políticos.

\section{Referências}

BARZOTTO, Luis Fernando. Filosofia e Constituição. In: MARTINS, Ives Gandra da Silva; MENDES, Gilmar Ferreira; NASCIMENTO, Carlos Valder (Coord.). Tratado de Direito Constitucional. v. 1. São Paulo: Saraiva, 2010. p. 617-653.

FLICKINGER, Hans Georg. A Luta pelo Espaço Autônomo do Político. In: SCHMITT, Carl. O Conceito do Político. Tradução de Alvaro L. M. Valls. Petrópolis: Vozes, 1992. p. 9-26.

HERRERO, Montserrat. La posición de lo Político: Schmitt frente a Strauss. In: RODRIGUEZ DE GRZONA, Mirtha (Comp.). Estudios sobre Leo Strauss. Mendoza: Centro de Estudios de Filosofia Clasica, 2010. p. 101-122.

MEIER, Heinrich. Carl Schmitt and Leo Strauss: the hidden dialogue. Translated by J. Harvey Lomax. Chicago and London: The University of Chicago Press, 1995.

MORGADO, Miguel. Introdução do Tradutor. In: STRAUSS, Leo. Direito Natural e História. Tradução de Miguel Morgado. Lisboa: Edições 70, 2009.

NOWAK, Piotr. Carl Schmitt and his critic. In: ARMADA, Pawel; GÓRNISIEWICZ, Arkadiusz (Ed.). Modernity and What Has Been 
O Conceito do Político e a Possibilidade da Filosofia Política na Modernidade...

Lost: Considerations on the Legacy of Leo Strauss. South Bend: St. Augustine Press; Krakow: The Jagiellonian University Press, 2011. p. 125-134.

PANGLE, Thomas L. Leo Strauss: an introduction to his thought and intellectual legacy. Baltimore: The Johns Hopkins University Press, 2006.

SCHMITT, Carl. O Conceito do Político. Tradução de Alvaro L. M. Valls. Petrópolis: Vozes, 1992.

SHELL, Susan. Taking Evil Seriously: Schmitt's "Concept of the Political" and Strauss's "True Politics". In: DEUTSCH, Kenneth L.; NICGORSKI, Walter (Ed.). Leo Strauss: political philosopher and Jewish thinker. Lanham: Rowman \& Littlefield Publishers, INC., 1994. p. 175-193.

STRAUSS, Leo. Direito Natural e História. Tradução de Miguel Morgado. Lisboa: Edições 70, 2009.

. Introduction to History of Political Philosophy. In: An Introduction to Political Philosophy: Ten Essays by Leo Strauss. Edited with an introduction by Hilail Gildin. Detroit: Wayne State University Press, 1989. p. 159-166.

. Natural Right and History. The University of Chicago Press: Chicago and London, 1953.

Notes on Carl Schmitt, The Concept of the Political. In: MEIER, Heinrich. Carl Schmitt and Leo Strauss: the hidden dialogue. Translated by J. Harvey Lomax. Chicago and London: The University of Chicago Press, 1995. p. 89-119.

. On Classical Political Philosophy. In: What is Political Philosophy and other studies. Chicago and London: The University of Chicago Press, 1988. p. 78-94.

. The Three Waves of Modernity. In: An Introduction to Political Philosophy: Ten Essays by Leo Strauss. Edited with an introduction by Hilail Gildin. Detroit: Wayne State University Press, 1989. p. 81-98.

. Three letters to Carl Schmitt. In: MEIER, Heinrich. Carl Schmitt and Leo Strauss: the hidden dialogue. Translated by J. Harvey Lomax. Chicago and London: The University of Chicago Press, 1995. p. 121-128. 
. What is Political Philosophy? In: What is Political Philosophy and other studies. Chicago and London: The University of Chicago Press, 1988. p. 9-55.

TANGUAY, Daniel. Leo Strauss: An Intellectual Biography. New Haven and London: Yale University Press, 2007.

ZUCKERT, Catherine; ZUCKERT, Michael. The truth about Leo Strauss: political philosophy and American democracy. Chicago and London: The University of Chicago Press, 2006.

Submissão: 05/11/2012 Aceito para Publicação: 21/08/2013 



\section{O Historicismo Jurídico}

\section{do Pensamento Montesquiano em Friedrich Carl von Savigny e suas Consequentes Implicações no Materialismo Histórico Marxista}

The Legal Historicism of Montesquieu's Thought in Friedrich Carl Von Savigny and its Consequential Implications on Marxist Historical Materialism

Matheus Zmijevski Custódio*

Resumo: Em uma época na qual a especulação político-jurídica ainda estava submersa em abstrações metafísicas, e em que a história e a lei positiva eram desprezadas, o pensamento de Montesquieu anunciou um direito com o propósito de ser fidedigno às reais condições em que a sociedade surge, existe e evolui. Montesquieu não acreditava que a infinita diversidade de leis e costumes fosse unicamente produzida pela fantasia humana, ou seja, uma obra poiética sem relação com a realidade. Em seus tratados - mais precisamente, em Do Espírito das Leis -, ele defende a consideração da história como fonte de conhecimento para captar o porquê das condutas humanas - que se dá conforme as circunstâncias - e examinar a adequação de suas leis a estas. Posteriormente, à semelhança de Montesquieu - inclusive, resgatando-lhe conceitos, tais como o do espírito geral da nação -, adveio a chamada Escola Histórica do Direito Alemã, a professar o ordenamento jurídico como algo historicamente identificado, bem como exclusivamente próprio de um determinado povo. Friedrich Carl von Savigny, um dos maiores expoentes dessa escola, sustentava que o direito vive na prática e no costume, que

* Universidade Federal do Rio Grande do Sul. 
são a expressão imediata da consciência jurídica popular. E isto seria devido ao fato de que todo povo tem um espírito, que se reflete numa numerosa série de manifestações, de modo que: moral, direito, arte, linguagem etc. são todos produtos espontâneos e imediatos desse espírito popular (o Volksgeist). Por sua vez, Karl Marx, que fora aluno de Savigny, acabou influenciado por muitos dos temas por este debatidos (tais como a propriedade), e foi-lhe fiel quanto ao princípio de que o direito procede do social - colocando-se, pois, nas mesmas diretrizes ponderativas empregadas por Montesquieu. No entanto, a perspectiva histórica de Marx possuía um sentido mais funcional do que a de seu antigo professor, não se reduzindo àquilo que considerava uma reverência exagerada às origens. Ele acaba por discordar da concepção de evolucionismo jurídico aplicada por Savigny (mais continuista), evidenciando a necessidade de lutar-se contra leis hostis aos reais costumes do povo, para, então, no âmbito do Estado e da sociedade, sanarem-se as desigualdades acarretadas pelo manejo legal oportunista.

Palavras-chave: Do Espírito das Leis. Espírito Geral da Nação. Escola Histórica do Direito Alemã. Consciência Jurídica Popular. Materialismo Histórico.

Abstract: In an era in which the legal-political speculation was still submerged in metaphysical abstractions, and that history and positive law were neglected, the thought of Montesquieu announced a law in order to be authentic to the real conditions in which society emerges, exists, and evolves. Montesquieu did not believe that the infinite diversity of laws and customs were solely produced by human fantasy, or a poietic work with no relation to reality. In his treaties - more accurately, in "The Spirit of the Laws" - he argues for the consideration of history as a source of knowledge to grasp the reason of human behavior - which occurs according to the circumstances - and examine the adequacy of its laws to these. Later, like Montesquieu - even recovering his concepts, such as the "spirit of the nation" - came the so-called "German Historical School of Law," professing the legal order as something historically identified and exclusively belonging to a particular people. Friedrich Carl von Savigny, one of the greatest exponents of this school, sustained that the law lives in the practice and custom, which are 
the immediate expression of "popular legal consciousness." And this would be due to the fact that every people has a spirit, which is reflected in a large number of events, so that: moral law, art, language, etc. are all spontaneous and immediate products of this popular spirit (the "Volksgeist"). In his turn, Karl Marx, who was a pupil of Savigny, were influenced by many of the topics discussed by Savigny (such as property), and remained faithful to him in the principle that the law comes from the social - placing himself, therefore, under the same guidelines employed by Montesquieu. However, the historical perspective of Marx had a more functional sense than that of his former teacher, because it's not reduced to what he considered an exaggerated reverence to the origins. After all, he disagreed with the conception of legal evolution applied by Savigny (more "continuist"), highlighting the need to fight against laws hostile to the actual customs of the people, and thereby, in the realm of State and society, eliminate inequalities brought about by the opportunistic legal management.

Keywords: The Spirit of the Laws. General Spirit of the Nation. German Historical School of Law. Popular Legal Consciousness. Historical Materialism.

\section{Introdução}

Considerado como aquele que forjou o sistema moderno de governar, Charles-Louis de Secondat, o Barão de Montesquieu e de La Brède, é amplamente conhecido e prestigiado, porém, nem sempre compreendido naquilo que realmente pretendeu lecionar. Frente a essa constatação, a relevância de seus escritos, principalmente para o meio jurídico, foi sempre inquestionável; contudo, embora eternizado em bustos de mármore, resta esquecido nas estantes das bibliotecas, negligenciado em um momento em que sua presença, ou seja, o resgate daquilo que de mais valioso professara, faz-se imprescindível. 
À atualidade, perante os problemas fundamentais do sistema e das falhas de operabilidade do direito, volver-se a Montesquieu é uma tentativa de buscar respostas na origem. Isto porque, além de ser um dos mentores do princípio governamental atualmente instituído, o barão figura como um dos fundadores da chamada ciência da legislação, responsável pela formação de uma classe de grandes autores, entre os quais, Friedrich von Savigny e Karl Marx, que, em seus discursos, seguem, senão iguais, semelhantes diretrizes.

Para o famigerado barão, cada aspecto concreto define seu direito dentro de um determinado contexto, eis que a história de cada povo é o molde de suas instituições. Concernente a isso, há, portanto, duas visões: uma, puramente historicista, bastante relativista; outra, puramente universal, que conduz à unificação padronizada. No fim, tem-se um problema de justo meio e, por isso, reapresenta-se Montesquieu como o intercessor necessário de uma possível solução.

Conforme o filósofo, a lei em si já possui um papel intermediador, o qual se está a perder; fato que, provavelmente, explica as tendências de universalização, já que o propósito da legislação parece ter-se alterado. Presentemente, deturpou-se a amplitude prática inerente às leis, à medida que se prefere partir de "a prioris". Em efeito, não mais se observa como os princípios de uma nação se manifestam no conjunto legal, o que é fundamental para se definir os âmbitos de uma atuação jurídica eficaz.

Nesse processo, o legislador não mais observa os fatos, visto estar mais preocupado em esculpir o direito. Em uma conjuntura dicotômica, o passo dedutivo opõe-se ao empírico, vez que o legislador, tido como o pedagogo da sociedade, 
comporta-se mais como o seu oráculo. Procede que a sustentação do direito como obra da vontade fulminou o empirismo legislativo, criando um tipo metafísico que, ao procurar as causas primeiras, pretende fundamentar a legislação longe do conhecimento do coração humano e das lições históricas.

Para Montesquieu, a história é a física experimental da legislação. Em seu "magnum opus", o célebre tratado Do Espírito das Leis (1748), ele lança um novo De Legibus, uma nova teoria geral sobre a lei. Segundo seus preceitos, se enxergarmos, numa percepção de cultura, aquilo que vem a ser a ordem natural e a ordem positiva, ponderamos, construímos e aplicamos o direito, não simplesmente ditamos ou importamos um pronto discurso. Hoje em dia, contudo, através de um idealismo voluntarista-utilitarista, vive-se um momento de quebra da tradição, impulsionado pela ideia de um universalismo extremo.

Não há, pois, espaço para a razão e a experiência, pois toda e qualquer discussão é firmada através de uma pauta dita oficial. $\mathrm{O}$ direito, igualmente a outros fatores sociais, passa a ser produto de uma técnica não racionalizada, passível de ser manipulada. E a noção de lei, quando não dificultada pelo movimento de abolicionismo legal, converge para uma criatividade muito distante do bem comum.

Trazer esses aspectos ao debate que se faz de Marx é remeter às bases mais primordiais do pensamento deste autor. Por intermédio das ideias de seu antigo professor, justamente Savigny, Karl Marx recepciona o baldrame teórico proveniente de Montesquieu, o que lhe dá azo para a elaboração do que, posteriormente, ficou-lhe conhecido como materialismo histórico. Em verdade, quanto à análise 
O Historicismo Jurídico do Pensamento Montesquiano...

sociológica do direito, ele se coloca no mesmo contexto que seus precedentes: Montesquieu, definitivamente o fundador; Savigny, remontando-o, o interlocutor entre ele e Marx, que, por sua vez, é aquele a apresentar uma proposta de aplicabilidade prática do que os outros dois haviam instituído - uma tentativa de fazer-lhes valer.

Crê-se, portanto, que é a partir de Montesquieu que melhor se compreenderá Savigny e, consequentemente, Marx, vez que, juntos, ainda figuram como referenciais determinantes no enfrentamento dos problemas jurídicos atuais.

\section{Contributo de Montesquieu}

\subsection{A Introdução do Elemento Histórico no Campo Jurídico}

No domínio particular da filosofia jurídica, é conhecido como os escritores precedentes a Montesquieu discutiram, principalmente, o problema racional do direito, negligenciando, ao contrário, o problema histórico, de gênese ${ }^{1}$. Em efeito, não se ocuparam do direito como fenômeno da história, mas somente como ideia e princípio especulativo, considerando, portanto, tudo o que o direito deve ser à preferência daquilo que é.

Agora, se as questões históricas tornaram-se predominantes apenas em princípios do século XIX, provocando uma sublevação até na doutrina da filosofia do direito, deve-se recordar que Montesquieu marca o início da passagem do

1 É o que observamos através de ALTHUSSER, Louis. Politics and history: Montesquieu, Rousseau, Hegel and Marx. London: New Left Review Edition, 1977. p. 19-21. 
método puramente racional ao método histórico ${ }^{2}$. Assim, demonstrou dominar a necessária imensidade de visão para compreender o que emana do terreno dos fatos humanos ${ }^{3}$, sistematizando-o dentro de um conceito cujas perspectivas ainda atraem o nosso interesse.

Tentativa esta que, na mesma época, encontra comparação somente na obra do napolitano Giambattista Vico, o qual, junto ao filósofo bordelês, é justamente considerado como o antecipador de uma nova corrente do pensamento ${ }^{4}$. Tal movimento, que, sucessivamente, há tido vários ramos de desenvolvimento, possui, contudo, um inconfundível significado característico de oposição ao raciocínio puro e abstrato.

Esse tipo de raciocínio, tido por muitos como tranquilo, é cotejado com o prejudicial descuido do material histórico e o desdém da contribuição que os fatos poderiam consentir à exata interpretação da realidade. Porém, graças a autores como Vico e Montesquieu, que dirigiram suas mentes vastas e geniais ao estudo dos fatos humanos, incluindo todos os produtos históricos e culturais, é que se manteve uma diretriz consciente disso.

Vallet de Goytisolo recorda que, para o senhor de La Brède, os povos também operam com sucessões de ideias, tanto que essa maneira de pensar total, como a de cada indivíduo, tem um começo, um meio e um fim. Por isso, pode-se

2 Segundo BALOG, Frank D. The Scottish enlightenment and the liberal political tradition. In: BLOOM, Allan (Org.). Confronting the constitution: the challenge to Locke, Montesquieu, Jefferson, and federalists from utilitarianism, historicism, marxism, freudianism, pragmatism, existentialism... Washington: The AEI Press, 1990. p. 206.

3 Como bem explica HULLIUNG, Mark. Montesquieu and the old regime. Berkeley: University of California Press, 1976. p. 3.

4 Assim demonstra DUNNING, William Archibald. A history of political theories: from Luther to Montesquieu. New York: The Macmillan Company, 1928. p. 389. 
O Historicismo Jurídico do Pensamento Montesquiano...

dizer que, em cada país, formam-se gerações de leis, as quais, sejam acessórias ou principais, refletem aquelas opiniões ${ }^{5}$.

Assim sendo, Montesquieu conclui que é preciso conhecer as leis antigas; não para alterar as novas, mas a fim destas bem utilizar. Isto porque, ao verificarmos antigas opiniões dominantes, obtemos um parâmetro muitíssimo útil: de um lado, empregando aquilo que elas produziram para o bem; e de outro, impedindo o que as mesmas haviam difundido para o mal' . E foi com tal finalidade que Montesquieu tratou de guiar os operadores do direito.

Em existindo relações de equidade anteriores à lei positiva, o bordelês compreendeu que os legisladores, mediante sua atividade, têm a missão de reintegrar os homens, quando esquecidos daquelas relações, ao cumprimento dos deveres para com os demais. Em razão disso, ele também procurou alertar sobre a grande quantidade de dados que tais legisladores, naquela missão, hão de considerar, sendo alguns contraditórios entre si. E, depois, que nunca se deve legislar conforme a fantasia, mas sempre em conformidade à natureza das coisas ${ }^{7}$.

Desse modo, dentro do conhecimento histórico do qual parte, o empirismo de Montesquieu não o conduz a um positivismo jurídico, até porque, para ele, não havia mais cruel tirania do que a exercida à sombra das leis e com as cores da justiça. Assim o relembra Yukio Uehara ${ }^{8}$, que

5 VALLET DE GOYTISOLO, Juan. Montesquieu: leyes, gobiernos y poderes. Madrid: Civitas, 1986. p. 245.

6 Ibidem, loc. cit.

7 Como trata MARKOVITS, Francine. Montesquieu: le droit et l'histoire. Paris: Librairie Philosophique J. Vrin, 2008. p. 121-125.

8 Ver UEHARA, Yukio. Les idées de nature et d'histoire dans la théorie juridique de Montesquieu. In: GOYARD-FABRE, Simone (Org.). Cahiers de philosophie politique 
também o coloca em contraste com o idealismo racionalista de Jean-Jacques Rousseau, que tentou buscar o direito pela via da lógica e da ficção.

Por sua vez, Goyard-Fabre bem captara a dimensão ontológica das leis humanas, mostrada por Montesquieu no Livro I de Do Espírito das Leis. Para a estudiosa9 ${ }^{9}$ Montesquieu deixa claro que a verdade das leis reside em sua determinação natural, pois sua razão primordial é a relação de necessidade que as vincula às coisas. Por isso, a lei de todas as leis positivas é a lei ôntica da natureza, ou seja, a que se refere a toda esquemática referente ao ser.

Em Montesquieu, há um retorno à inspiração metafísica da política aristotélica ${ }^{10}$, distante de uma ciência mecanicista que revela a estrutura não eliminável do ser ético-político ${ }^{11}$. Por isso, mais que um ato de justiça, a lei humana é uma regra de prudência preexistente, referida à previsão do bem comum, e, como todo juízo prudencial, deve partir do conhecimento da realidade ${ }^{12}$.

Nesses moldes, a formulação das leis humanas demandará a dirigente investigação dos sábios (o juízo dos peritos, dos anciãos ou dos prudentes), de forma que resultem adequadas ao lugar, ao tempo, aos costumes e às faculdades

et juridique: la pensée politique de Montesquieu. Caen: Centre de Publications de l'Université de Caen, 1985. p. 71-84.

9 Ver GOYARD-FABRE, Simone. La philosophie du droit de Montesquieu. Paris: Libraire C. Klincksieck, 1973. p. 70 et seq.

${ }^{10}$ Muitos princípios aristotélicos estão incutidos em Montesquieu, como a separação dos poderes e as formas de governo. Ver ARISTÓTELES. A política. São Paulo: Martins Fontes, 2006, passim.

11 VALLET DE GOYTISOLO, Juan. Montesquieu: leyes, gobiernos y poderes. Madrid: Civitas, 1986. p. 169.

12 Nesse sentido, o estudo de FINNIS, John. Lei natural e direitos naturais. São Leopoldo: Editora Unisinos, 2006, passim. 
O Historicismo Jurídico do Pensamento Montesquiano...

de quem as deve cumprir. E não se trata, pois, da expressão de uma razão abstrata, dedutiva, mas de uma razão vital e histórica, ao fim do bem comum e da utilidade pública ${ }^{13}$.

$\mathrm{O}$ exposto, nesses moldes, estaria a indicar que as leis não devem ser indiscriminadamente iguais para todos os países ou em qualquer espaço-tempo. Montesquieu, filiando-se a essas linhas, explica que as leis políticas e civis de cada nação necessitam apropriar-se ao povo para o qual são feitas, considerando que não podem passar de casos particulares nos quais a razão humana se aplica. Assim, o conjunto de leis de um determinado país somente convirá a outro em oportunidades bastante fortuitas ${ }^{14}$.

$\mathrm{Na}$ mesma passagem em que aborda essas colocações ${ }^{15}$, Montesquieu também relaciona os fatores determinantes para que as legislações sejam apropriadas, não importando o momento e o lugar. Sintetizemo-los, portanto, como base de seu método jurídico fundamentado na lei, a qual deverá: corresponder ao princípio do governo estabelecido; atender às características do país e de seus habitantes (tradições, condições geográficas etc.); e relacionar-se com as demais, inclusive com sua origem, com as metas do legislador e com a ordem das coisas sobre as quais se estabelece. Finalmente, são essas pertinências que, em pleno conjunto, formam o chamado "espírito das leis".

${ }^{13}$ Ver o “Artigo 3" da "Questão 95" em TOMÁS DE AQUINO, São. Suma de teología: parte I-II. t. 2. Madrid: Biblioteca de Autores Cristianos, 1989. p. 743-744.

14 MONTESQUIEU, Charles-Louis de Secondat, Barão de. De l'esprit des lois. v. 1. Paris: Flamarion, 1979. p. 128.

${ }^{15}$ Ibidem, loc. cit. 


\subsection{A Noção de Espírito}

Montesquieu fala do espírito geral e do espírito geral da nação, dando a ambos igual sentido, à medida que o espírito geral se refere a cada país ${ }^{16}$. Alguns dos denominados românticos alemães, como Hegel e a escola histórica empregaram a expressão "Volksgeist" (espírito do povo), sendo que o próprio Hegel empregaria alguma vez, com similar sentido, a palavra "Nationalgeist" (espírito nacional). No entanto, esta expressão parece que não surgiu na Alemanha, mas que foi anteriormente empregada na França, onde foi utilizada por Montesquieu e Voltaire, e sua origem se encontra na Inglaterra ${ }^{17}$.

Essa origem inglesa da expressão é mostrada por Joseph Dedieu, que indica que, no mesmo século XVIII, mas anos antes, um certo Lord Bolingbroke expôs uma teoria do espírito geral, demonstrando que os povos têm máximas que formam seus hábitos e costumes. Ademais, que a eles devem se adaptar os governos com pretensão de durar, pois carregam uma virtude incoercível, além de conduzirem as vontades e dirigirem as atividades. No livro deste autor, Ideia de um Rei Patriota, desponta-se, portanto, o conceito de um grande espírito nacional, o qual é capaz de coisas tão grandiosas quanto ${ }^{18}$.

Da expressão "espírito geral de uma nação", Montesquieu produz uma noção englobante, como uma manifestação

${ }^{16}$ BERENKASSA, Georges. Montesquieu. Paris: Presses Universitaires de France, 1968. p. 107.

17 VALLET DE GOYTISOLO, Juan. Op. cit., p. 203.

18 DEDIEU, Joseph. Montesquieu et la tradition politique anglaise en France: les sources anglaises de l’Esprit des Lois. Paris: Librairie Victor Lecoffre, 1909. p. 262-282. 
mais completa da natureza das coisas ${ }^{19}$. Para alguns, ainda é crível que ele não chega a formular algo superior que defina e inspire as instituições jurídicas do povo, não perfilando um "espírito do direito", mas que concretiza uma série de condicionamentos necessários para estabelecer leis positivas adequadas; e seria a soma desses condicionamentos o que ele chama de "espírito das leis" 20. Assim, o princípio não é, pois, algo superior, senão um resultante, um conceito teórico geral.

De fato, Montesquieu desligou a legislação do arbitrário, do capricho dos homens e do azar das circunstâncias, e a religou, tanto quanto pela moral, pela psicologia e pela história, ao tronco comum da natureza humana. $\mathrm{O}$ "espírito das leis" vem a resultar em um componente tanto de causas eficientes como finais. Nesses sentidos, Vallet de Goytisolo ressalta o furor causal de Montesquieu, indicando, com base no livro do barão sobre os romanos, uma combinação "híbrida" do velho esquema das causas aristotélicas, aplicado livremente com o mecanicismo da nova ciência cartesiana ${ }^{21}$.

Explica Starobinski que o bordelês dissera que, tomando consciência da justa relação que existe entre nós e as coisas, tornamo-nos capazes de fazermos a nós mesmos: fazemo-nos o espírito que preferimos e somos os verdadeiros artesãos. Segundo Montesquieu, o espírito carrega uma faculdade que o homem tem de conhecer a justa relação que existe entre as coisas e ele, de uma maneira universal, compondo-o. $\mathrm{O}$ espírito,

${ }_{19}$ Assim escreve IGLESIAS, María del Carmen. El pensamiento de Montesquieu. Madrid: Alianza Universidad, 1984. p. 394-396.

${ }^{20}$ Ibidem, loc. cit.

${ }^{21}$ VALLET DE GOYTISOLO, Juan. Montesquieu: leyes, gobiernos y poderes. Madrid: Civitas, 1986. p. 205. 
em sua plenitude, compõe-se da imaginação que aproxima as coisas distantes e do juízo que distingue as confusas ${ }^{22}$.

O barão tinha o ímpeto de mostrar os nexos necessários que derivam da natureza das coisas; mostra-os e, simultaneamente, descobre que esses nexos não são absolutamente necessários. A originalidade de Montesquieu, conforme Vernière, consiste em ele ter querido conciliar, na concepção pluralista de "espírito geral", uma política positiva, fundada na interpretação objetiva dos fatos, e uma política idealista, fundada no conceito de justiça ${ }^{23}$.

Para o filósofo bordelês, a razão que se exerce na ordem experimental não contradiz a razão que exige a infusão nos fatos de uma moral e de uma espiritualidade. É o que chamamos de razão impura, vez que, até o advento do criticismo kantiano, a filosofia das luzes não concebera a separação desta dupla legitimidade ${ }^{24}$. Como composição dessas contradições, temos que, no pensamento montesquiano, as leis devem se sustentar em princípios naturais imutáveis, mas estão em relação com determinadas relações particulares (o clima, a natureza física, a índole do povo etc. ${ }^{25}$. E exatamente por isso que elas valerão para o povo que as expressar, e enquanto não se alterarem as condições em que o foram.

Alcançar através das leis as ordens da razão é encontrar a última razão de ser. As leis são um material acerca do

${ }^{22}$ STAROBINSKI, Jean. Montesquieu. Ciudad de México: Fondo de Cultura Económica, 1989. p. 49.

${ }^{23}$ VERNIÈRE, Paul. Montesquieu et l'esprit des lois ou la raison impure. Paris: Société d'Édition d'Enseignement Supérieur, 1977. p. 101.

${ }^{24}$ Ibidem, loc. cit.

${ }^{25}$ BRÈTHE DE LA GRESSAYE, Jean. L'histoire de l'esprit des lois. In: MIRKINE-GUETZÉVITCH, Boris et al. La pensée politique et constitutionnelle de Montesquieu: bicentenaire de l'esprit des lois: 1748-1948. Paris: Recueil Sirey, 1952. p. 70-73. 
O Historicismo Jurídico do Pensamento Montesquiano...

qual Montesquieu praticara uma experimentação conduzida pelos mais recentes métodos do seu tempo. Porém, mesmo empenhado na via positiva, ele não abandona os caminhos tradicionais da reflexão filosófica ${ }^{26}$. Para o barão, a ideia da justiça é anterior e superior a todas as leis humanas, bem como inscrita na consciência das pessoas. Não são, pois, de modo algum, os homens quem arbitrariamente decidem o que é justo ou injusto: seus decretos necessitam referir-se a um modelo transcendente formado por suas aspirações ${ }^{27}$.

Como aprendemos em Goyard-Fabre, diz-se que Montesquieu estudara as leis humanas como fatos sociais, tal como se estuda os fatos naturais, submetendo-os à análise redutora da filosofia experimental. Nisso, descobre que elas, como as regras pelas quais Deus estabelecera a ordem no mundo, não contêm nada de arbitrário (pelo menos em sua essência), e, como as leis da criação, respondem à natureza das $\operatorname{coisas}^{28}$.

Depois, ainda constata que existe uma lei de todas as leis, que é forma racional. Em conjunto e enquanto relações, esta lei rotulada suprema e todas as demais formam o que se chama de o "espírito das leis". Mas não se deve confundir as leis como sendo o seu espírito. As leis são feitas para anunciar as ordens da razão a quem imediatamente não pode desta receber (uma alusão a Platão) ${ }^{29}$. Assim, atender essas ordens

${ }^{26}$ VALLET DE GOYTISOLO, Juan. Montesquieu: leyes, gobiernos y poderes. Madrid: Civitas, 1986. p. 208.

${ }^{27}$ Nesse sentido, BAUN, Alan. Montesquieu and social theory. Oxford: Pergamon Press, 1979. p. 97.

${ }^{28}$ GOYARD-FABRE, Simone. La philosophie du droit de Montesquieu. Paris: Libraire C. Klincksieck, 1973. p. 83.

${ }^{29}$ Ibidem, loc. cit. 
através das leis significa encontrar sua razão última, de serem tais como são.

Por conseguinte, as leis em si são apenas um material; material esse que Montesquieu observa e submete ao escalpelo da experimentação. Já o espírito das leis é uma forma universal e necessária, que o bordelês descobre como princípio constitutivo e regulador (o que, mais tarde, provavelmente veio a Hans Kelsen influenciar). Todavia, não o é somente de todas as constituições humanas, mas, sobretudo, de tudo o que existe.

Antes que se fizessem leis, eram possíveis relações de justiça, e dizer que nada há de justo ou injusto a não ser o que ordenam ou proíbem as leis positivas, seria idêntico a afirmar que nenhum dos raios era igual antes de traçar-se um círculo $^{30}$. É preciso conhecer relações de equidade anteriores à lei positiva que as estabelece.

Também é necessário que o mundo inteligente esteja tão bem governado como o mundo físico. Mas, ainda que aquele também tenha leis que sejam invariáveis, ele não as segue como o mundo físico segue as suas, ou seja, constantemente. Os seres particulares inteligentes são limitados por sua natureza. Eles atuam por si mesmos e, destarte, ficam sujeitos ao erro, o que os faz ignorarem as leis originárias, inclusive aquelas que eles próprios se dão no íntimo de suas consciências $^{31}$.

Essa limitação natural, produzida tanto pela sujeição à ignorância quanto pelo peso das próprias paixões, trouxe implicações: tornou necessário que Deus nos manifestasse

${ }^{30}$ Ibidem, loc. cit.
${ }^{31}$ Ibidem, loc. cit. 
O Historicismo Jurídico do Pensamento Montesquiano...

pelas leis da religião; que os filósofos nos advertissem pelas leis da moral; e que os legisladores nos reintegrassem a nossos deveres pelas leis políticas e civis $^{32}$. Conforme aludido, as leis realmente estão feitas para anunciar as ordens da razão a quem não pode dela imediatamente receber.

Contudo, as limitações da natureza humana também atingem os filósofos, os legisladores e os governantes, por estarem afetados, em maior ou menor grau, pelas circunstâncias religiosas, morais, físicas, econômicas e sociais, em cada momento histórico concreto e em seus hábitos, costumes e leis vigentes. Daí que o espírito de cada povo e de cada nação as reflete. Por isso, quando há corrupção nos mais variados tipos governamentais, esta começa quase sempre pelos princípios ${ }^{33}$.

Para conduzir-se pela razão, Montesquieu estima que há de atuar-se prudentemente. Se for verdade que o caráter de espírito e as paixões do coração são extremamente diferentes entre lugares distintos, as leis devem ser adequadas às peculiaridades. Algo possível para quem se cinge do hábito da virtude pode não o ser para quem dela carece. As leis devem se impor aos homens atendendo à sua condição, que, por ser diversa e volátil, fá-las alterar, à medida que é natural à razão humana avançar gradualmente do imperfeito à perfeição.

32 GOYARD-FABRE, Simone. La philosophie du droit de Montesquieu. Paris: Libraire C. Klincksieck, 1973. p. 83.

${ }^{33}$ MONTESQUIEU, Charles-Louis de Secondat, Barão de. De l'esprit des lois. v. 1. Paris: Flamarion, 1979. p. 243. 


\section{As Ingerências do Pensamento Montesquiano em Savigny e Marx}

\subsection{Montesquieu e a Escola Histórica do Direito}

Em tal modo, se cada uma das legislações nacionais singulares apresenta - e deve apresentar - essas imanentes características de particularidade ${ }^{34}$, legitima-se a proposição na qual, em síntese, está inclusa a ideia conclusiva de Montesquieu sobre o problema da comunicabilidade do direito: "[As leis] devem ser tão próprias ao povo pelo qual elas são feitas, que é um grande perigo se as de uma determinada nação convenham a uma outra" (tradução nossa) $)^{35}$.

Não obstante, como um elo que se acede a essa corrente, mas por inspirações procedentes de um radicalismo muito maior que o de Montesquieu, houve, ainda, na Alemanha, a chamada Escola Histórica do Direito (Historische Rechtsschule $)^{36}$. Segundo esta última escola, que é comumente chamada de "escola histórica dos juristas alemães", todo ordenamento jurídico é algo historicamente identificado, bem como exclusivamente próprio de um determinado povo. Deste, tal ordenamento é inseparável, não estando sequer sujeito a enxertos ou transmigrações ${ }^{37}$.

${ }^{34}$ Ver BARRERA, Guillaume. Les lois du monde: enquête sur le dessein politique de Montesquieu. Paris: Gallimard, 2009. p. 117-118.

35 Elles doivent être tellement propres au peuple pour lequel elles sont faites, que c'est un très grand hasard si celles d'une nation peuvent convenir à une autre. MONTESQUIEU, Charles-Louis de Secondat, Barão de. Op. cit., p. 128.

${ }^{36}$ Como relaciona BENOIT-SMULLYAN, Emile. An outline of the history of political theory: part II: Montesquieu to present. Boston: Student Outlines Company, 1957. p. 14.

${ }^{37}$ Nesse sentido, ver HERNÁNDEZ MARCOS, Maximiliano. Carl Gottlieb Svarez y la disolución del derecho natural en Alemania. In: Artículos de la Biblioteca Saavedra Fajardo de Pensamiento Político Hispánico. Múrcia: Faculdad de Murcia, [s.d.], passim. 
Friedrich Carl von Savigny, um dos maiores expoentes dessa escola, sustenta que o direito vive na prática e no costume, que é a expressão imediata da "consciência jurídica popular". Isto é devido ao fato de que todo povo tem um espírito, uma alma sua, que se reflete numa numerosa série de manifestações, de modo que: moral, direito, arte, linguagem, etc. são todos produtos espontâneos e imediatos desse espírito popular (o "Volksgeist") $)^{38}$.

Assim como a linguagem surge e se desenvolve sem o trabalho dos gramáticos, que só depois lhe fixam os princípios e regras, também o direito não é criação do legislador, mas uma produção instintiva e quase inconsciente que se manifesta no fato, e apenas numa fase posterior admite a elaboração refletida por obra dos técnicos, que são os juristas ${ }^{39}$. Por isso, as leis, segundo Savigny, têm uma função de todo secundária, que, às vezes, pode ser até danosa.

Elas não fazem mais que fixar e quase imobilizar os elementos já elaborados da consciência jurídica popular. Esta é a única fonte autêntica e genuína do direito. Daí a aversão de Savigny e da escola histórica em geral contra a legislação e contra a codificação. Em sua opinião, os códigos são majoritariamente danosos porque, em sendo sínteses sistemáticas das leis, eles adquirem maior estabilidade e podem, então, obstar o curso e a evolução espontânea do direito ${ }^{40}$.

Relevante é o dado de como o conceito de "espírito popular", que subjaz na asserção da escola histórica sobre

${ }^{38}$ GOYARD-FABRE, Simone. La philosophie du droit de Montesquieu. Paris: Libraire C. Klincksieck, 1973. p. 289.

39 ASSIER-ANDRIEU, Louis. O direito nas sociedades humanas. São Paulo: Martins Fontes, 2000. p. 113-114.

${ }^{40}$ Ibidem, p. 115. 
o caráter inderrogável da particularidade fenomenológica jurídica, descobre um cotejo no conceito montesquiano de "espírito geral da nação" ${ }^{41}$. Neste particular aspecto, tanto Montesquieu quanto a escola histórica, depois de terem verificado a existência de uma pluralidade de sociedades nacionais, das quais deriva uma pluralidade de direitos positivos, consideram esta pluralidade insuperável (escola histórica) ${ }^{42}$ ou que se deve evitar superar (Montesquieu).

Por outro lado, a particularidade dos povos não encerra a questão, pois também estaria em jogo uma humanidade das nações, a humanidade do direito, isto é, a sua universalidade. Contudo, deve-se ter bastante cuidado em tratar desses temas, pois, entre posicionamentos mais extremados, pode-se deparar com o embate intransigente entre uma individualização totalitária e uma universalização absoluta. Pensamos que Montesquieu, ciente de que não se podia ir nem a uma, nem a outra, foi moderado em relevar tais aspectos ${ }^{43}$.

Mas dado que o direito fosse algo exclusivamente histórico, relativo somente ao lugar e ao tempo da sua gênese, e, portanto, desprovido de qualquer valor humano e universal, ele realmente não envolveria aplicações a pessoas diversas, nem mais transcenderia seus limites étnicos e temporais. Por conseguinte, em insistir exclusivamente sobre o dogma da particularidade irredutível de toda produção jurídica nacional, arrisca-se a fazer tantos direitos quanto há nações.

\footnotetext{
${ }^{41}$ Ibidem, p. 118.

42 Ibidem, p. 123.

${ }^{43}$ É de sua personalidade, como aponta FUSIL, Casimir Alexandre. Montesquieu: pages choisies. v. 1. Paris: Librairie Larousse, [s.d.], p. 95.
} 
Porém, a despeito disso, a escola histórica assim o $\mathrm{fez}^{44}$, demonstrando sobre este aspecto um radicalismo bem maior que Montesquieu, o qual praticamente não chega a uma similar pulverização da substancialidade jurídica, pois afirma ser a razão a origem fundamental do direito, seja universal ou particular ${ }^{45}$.

\subsection{A Receptividade Savigniana a Montesquieu}

Savigny dialoga com Montesquieu e juntos representam um curioso intercâmbio franco-alemão no debate da problemática do direito. Certamente, é a assimilação do direito a um fato de cultura inscrito na história, e por isso capaz de caracterizar a sociedade da qual ele emana, que constitui a contribuição essencial de Savigny e da Escola alemã denominada "do direito histórico", motivo pelo qual ela retoma igualmente a herança de Montesquieu em sua busca do "espírito geral".

Em 1814, Savigny publicou a obra Vom Beruf unserer Zeit für Gesetzgebung und Rechtswissenschaft (A Vocação de Nosso Tempo para a Legislação e a Ciência do Direito) ${ }^{46}$, que foi uma resposta à proposta de Thibaut em defender a codificação do direito civil na Alemanha. Neste tratado, o alemão

${ }^{44}$ Entre outros diferentes motivos, algo que pode ter influenciado Marx a escrever contra seu antigo professor, Savigny. ASSIER-ANDRIEU, Louis. Op. cit., p. 122.

${ }^{45}$ Assim indica WILFERT, Joël. Montesquieu: ou la hantise du despotisme. In: GRATELOUP, Léon-Louis (Org.). Les philosophes: de Platon à Montesquieu. v. 1. Paris: Hachette, 1985. p. 370.

${ }^{46}$ Para consulta traduzida da língua alemã, sugere-se a seguinte versão (mais contemporaneamente próxima ao autor): SAVIGNY, Friedrich Carl von. Of the vocation of our age for legislation and jurisprudence. Tradução de Abraham Hayward. Londres: Littlewood, 1831. 
defende que o objetivo da ciência jurídica é apresentar historicamente as funções legislativas do Estado, cuja legislação possui uma dupla realidade (funções): estabelece os direitos que este Estado almeja garantir aos cidadãos (direito civil) e refere-se às disposições protetoras do que é posto (direito criminal). A obedecer tais circunstâncias, as normas devem se deduzir dos princípios fundamentais, de modo que a ciência legislativa seja histórica (concebida em dado período e em constante progresso) e filosófica (jurisprudência; sistematização e interpretação $)^{47}$.

Com Savigny, o direito investe o Estado, não procede dele, pois é uma parte da existência orgânica da comunidade. A consciência jurídica comum ou popular, portanto, é a noção central em Savigny e, assim como o "espírito geral da nação" em Montesquieu, trata-se de uma teoria culturalista do fenômeno jurídico. A consciência comum é aquilo pelo que uma cultura jurídica se vincula à cultura pura e simples, procedendo, assim, de sua personalidade própria. Por isso, à semelhança com o barão, o alemão apresenta o chamado "Volksgeist" tanto como o ponto de convergência de peculiaridades, locais ou étnicas, quanto como a própria universalidade, o direito natural de uma razão comum (que há tomado forma no tempo e se adaptara a uma sociedade) ${ }^{48}$.

A comparação entre as visões savigniana e montesquiana é extremamente nítida, sendo que esta exerce uma grande influência sobre aquela. Esse "espírito do povo" reflete e coleta uma consciência nacional, a consciência comum

${ }^{47}$ Ver MAZZACANE, Aldo. Savigny e la storiografia giuridica tra storia e sistema. Nápoles: Liguori, 1983.

${ }^{48}$ MARKOVITS, Francine. Montesquieu: le droit e l'histoire. Paris: Librairie Philosophique J. Vrin, 2008. p. 35-38. 
O Historicismo Jurídico do Pensamento Montesquiano...

do povo, vez que a lei positiva deve tão somente refleti-la, não tendo, por si, nenhum papel criador para com o direito. Outra consequência é a de que o campo jurídico possui uma natureza plural, que se encontra plenamente assumida em um raciocínio que integra sua historicidade.

À sua vez, Savigny substitui a investigação das leis universais pela pesquisa dos critérios dos quais os povos tiram sua individualidade, concluindo, pois, que o direito é típico de cada nação - primeiramente, nos costumes; após, na ciência. Com isso, também assevera que o direito evolui com o povo, mediante o progresso artificial definido pelos juristas. Disso, resulta que os conceitos acompanham a complexidade da civilização, mas estão sempre atrelados ao "Volksgeist" 4 .

Em suma, ao basear-se em Montesquieu, Savigny até mais audaciosamente - atrela a substância profunda do direito ao "gênio" de cada povo, tornando o Estado de Direito absolutamente solidário à nação, que é encarada como uma agregação de traços culturais singulares, sintetizados pela concepção de consciência comum.

\subsection{Marx e a Reformatação da Perspectiva Histórica de Savigny}

Até aqui, viu-se que Savigny concebeu teoricamente a coexistência histórica entre o direito "atributo de cultura", buscado nos fatos consuetudinários, e o direito "função técnica", instrumentada pelas funções do Estado. Junto a isso, outro relevante dado é saber que Karl Marx foi seu aluno na Universidade de Berlim, exatamente na cátedra de

${ }^{49}$ SAVIGNY, Friedrich Carl von. Op. cit., passim. 
"jurisprudência", vez que, desse seu professor, herdara o interesse pelo estudo da propriedade e, sobretudo, a visão de que o direito procede do social. Muitos - entre eles, Ludwig Von Mises - até consideram que, em alguns aspectos, a influência de Savigny em Marx é superior à de Hegel ${ }^{50}$.

Assim sendo, desde cedo, Marx buscou explorar ao máximo a oposição que lhe foi demonstrada pelo seu mestre na faculdade, aquela existente entre a juridicidade ancorada na consciência do povo e a legalidade manejada pelos juristas no seio da sociedade política ${ }^{51}$. E é neste ponto que o autor de Das Kapital percebe um problema ainda hoje existente, e que talvez sempre tenha existido: a manipulação das leis por interesses alheios aos seus legítimos propósitos. Nesses termos, pode-se asseverar sem dúvidas que, por intermédio de Savigny, Montesquieu apresenta-se como uma "chave de leitura" - importantíssima por sinal - para se compreender esse aspecto bastante relevante em Marx, o que tem sido pouco observado pelos seus investigadores atuais.

A despeito disso, ocorre que, diferentemente de Savigny, a perspectiva histórica de Marx não se reduz a uma reverência das origens. A ideia das fontes tem para ele um sentido funcional, mais prático: a consciência comum deixa de ser uma ficção especulativa para ser um fator concreto, inserido nas relações sociais, que define um conjunto de regras precisas oponíveis à legalidade do Estado quando este pretende contradizê-las. Em contemplação - e também respeito - às teorias sociojurídicas de seus predecessores,

${ }^{50}$ MISES, Ludwig von. Marxism unmasked: from delusion to destruction. New York: Foundation for Economic Education, 2006, passim.

${ }^{51}$ Ver ASSIER-ANDRIEU, Louis. O direito nas sociedades humanas. São Paulo: Martins Fontes, 2000. p. 99 et seq. 
O Historicismo Jurídico do Pensamento Montesquiano...

para Marx, o direito não deixa de ser costume ao se construir em lei; apenas deixa de ser exclusivamente costume ${ }^{52}$.

Destarte, Marx claramente recepciona as lições de Savigny, no sentido de que muito se inventa o direito contra a tradição. Contudo, Marx as torna mais operatórias, devendo ser lido como a dialética entre a consciência comum e o direito técnico. Na verdade, Marx transpõe a luta de Savigny contra a codificação para a luta contra leis hostis, ou seja, as contrárias aos costumes reais do povo, inclusive para a defesa destes justamente através das manifestações concretas dos mesmos - cuja juridicidade e legalidade ele reivindica de acordo com a mais pura retórica savigniana.

Apesar disso, de eminente aluno, Marx é igualmente um dos primeiros críticos de seu professor, pois reprova acintosamente a frouxidão com que seu mestre e a escola histórica trataram a questão do evolucionismo jurídico. $\mathrm{O}$ mérito de Savigny foi indicar que o direito é um produto histórico e que, como tal, amolda-se aos movimentos da história. Todavia, seu limite foi privilegiar as continuidades, ligadas à intangibilidade do caráter nacional, em relação às transformações, nascidas das distorções sociais. Para Marx, isso seria justificar a infâmia do presente pela infâmia do passado ${ }^{53}$.

Ademais, é a partir dessas questões que Marx, com a colaboração de Friedrich Engels, acaba ordenando sua abordagem metodológica quanto ao estudo da sociedade, da economia e da história, método que, posteriormente, foi

52 ASSIER-ANDRIEU, Louis. O direito nas sociedades humanas. São Paulo: Martins Fontes, 2000. p. 99 et seq.

${ }^{53}$ Muitos repugnam a imagem convencional de que Savigny é o representante principal do historicismo no mundo jurídico, atribuindo o verdadeiro título a nomes como Montesquieu, Voltaire e Vico, tal como se critica em PELAEZ, Francisco J. Contreras. Savigny y el historicismo jurídico. Madrid: Tecnos, 2005. 
denominado "materialismo histórico". Tal método procura as causas de desenvolvimentos e mudanças na sociedade humana nos meios pelos quais os seres humanos produzem coletivamente as necessidades da vida ${ }^{54}-\mathrm{a}$ influência montesquiana para com esta ponderação é notória.

Em específico, Marx considera que as classes sociais e a relação entre elas, além das estruturas políticas e as formas de pensar de uma dada sociedade, seriam todas fundamentadas na atividade econômica desta. Entretanto, além disso, o fato de Marx estar ligado a essa percepção material da vida e, por conseguinte, vinculado ao entendimento das relações humanas a partir dessa lógica da realidade cotidiana, traz a possibilidade de compreender-se que o pensamento marxista se estrutura, principalmente, por meio do que Montesquieu e Savigny haviam antes colocado.

Por fim, em Marx, o propósito de uma história pautada no materialismo aparece como uma oposição ao idealismo. A realidade dos povos, segundo o autor, não pode ser explanada a partir de um parâmetro que entenda as ideias como um fator de primeiro plano, uma vez que estas somente encontram o seu valor enquanto fornecedoras dos alicerces que sustentam a imensa estrutura econômica - que, melhor dizendo, nada mais é do que o próprio mundo material, isto é, real. Crê-se, pois, que é Montesquieu o primordial responsável pelo ensejo da análise sociojurídica marxista, o que não aconteceria sem a cooperação de Savigny, e que, de algum modo, os três pensadores complementam-se, ressalvadas, claro, suas diferentes peculiaridades.

${ }^{54}$ BUKHARIN, Nikolai. Historical materialism: a system of sociology. New York: Routledge, 2011. 


\section{Considerações Finais}

Ante as proposições desses autores, conclui-se que, essencialmente, o direito e seus instrumentos permanecem como meios eficazes, tanto na preservação da ordem quanto na legitimidade das transformações sociais. Entretanto, não se pode depositar exclusivamente na legislação a confiança de que ela nos dará tudo o que é preciso, pois seria uma atitude depreciativa em relação ao que o próprio instituto pode ofertar. Além disso, também não se deve contaminá-la com o que não lhe é peculiar e tampouco afastá-la daquilo a que ela deve se reportar (a natureza das coisas, sejam elas físicas ou morais).

Por fim, lembremos que esses pensadores, ao lidarem com nossas diferenças, quiseram mostrar o que a todos é comumente característico. Suas teorias carregam a constatação de que o direito se manifesta segundo as peculiaridades de um mundo que não é exatamente igual, mas levando em conta o que é essencialmente típico ao ser humano. Em efeito, frente a um contexto de sociedades bastante divergentes, há de considerar-se que Montesquieu, Savigny e Marx são capazes de prover, por intermédio de sua visão sociojurídica, uma coexistência mais integrativa, na qual não existam tantas inconsistências, disparidades e imposições.

Depois, em um país tão plúrime como o Brasil, o estudo específico de Montesquieu, com o auxílio da sensibilidade savigniana e da praticidade marxista, necessita ser de fato mais e melhor exercitado. Destarte, é crível que o barão pode em muito assessorar, por exemplo, na elucidação do que exatamente corresponde o "espírito do povo brasileiro" - se é que ele realmente existe - e de que forma ele é contemplado 
na legislação deste país, que é, sob todos os aspectos, uma nação manifestamente multicultural.

Contudo, tal estudo não deve ser feito para, nesses autores, encontrar-se um reconfortante espelho das certezas políticas atuais, e, sim, pelo fato de suas obras, ainda hoje, trazerem-nos um olhar mais lúcido e crítico sobre nossa situação em sociedade - até para que se promova a superação das dificuldades da metodologia jurídica atual. Outrossim, à medida que os investigamos, a suposta contradição entre determinismo histórico e idealismo social tende a desaparecer.

A questão primordial é buscar o equilíbrio entre a natureza física e a natureza moral que estão presentes na formação da sociedade; daí a importância desses ensinamentos para dirimir os impasses que atualmente vivenciamos. Isto porque são entendimentos de como a justiça pode se manifestar no seio social e de como ela pode nos conduzir à nossa realização, considerando-se, pois, que a característica fundamental da natureza humana, em resposta às necessidades do meio, é a sua capacidade de produzir e aplicar regras - por sua vez, sempre múltiplas e volúveis, exigidas pela própria natureza das coisas.

Logo, a noção de "espírito geral" e, ou "consciência popular" resumiria a complexa relação causal que se estabelece entre a ordem natural física e a múltipla realidade social que os homens criaram em diferentes espaços e tempos históricos. E ela não é uma soma, e, sim, uma combinação de constantes (clima, território etc.) e de variáveis (leis, tradições etc.), formando um conjunto evolutivo. Atualmente, porém, pela presença majoritária de uma tendência globalizadora e tecnicista, essa visão tem-se lastimavelmente esvaecido, e em simultâneo detrimento das fontes do direito que 
O Historicismo Jurídico do Pensamento Montesquiano...

não os modelos codificados - o que, ante o todo o exposto, é deveras insensato.

Desse modo, as preleções de Montesquieu - as próprias e as subsumidas nos pensamentos de Savigny e Marx ressurgem como forma de se resgatar uma ponderação mais eficaz sobre a realidade. Juntos, os autores compõem o alicerce teórico necessário para tanto, o qual também reconcede à ciência jurídica a sua verdadeira preeminência, dada por aqueles que, há dois, três séculos atrás, aceitaram a lição da história quando da fundação da legalidade das novas sociedades políticas. Afinal, o direito não pode ser um "mercado de serviços".

Por isso, em definitivo, é preciso decidir-se: ou pelo direito enquanto produto e conteúdo da lei, que é uma declaração voluntária de um poder que sanciona o que lhe parece justo, útil, razoável e de boa política; ou pelo direito como sendo derivado das relações necessárias das coisas (as quais resultam de todo o desenvolvimento social e político de um povo - de seus costumes, de suas necessidades e de sua história), que existe independentemente da lei e que é apenas o reconhecimento, pelo legislador, dessa própria necessidade.

\section{Referências}

ALTHUSSER, Louis. Politics and history: Montesquieu, Rousseau, Hegel and Marx. London: New Left Review Edition, 1977.

ARISTÓTELES. A política. São Paulo: Martins Fontes, 2006.

ASSIER-ANDRIEU, Louis. O direito nas sociedades humanas. São Paulo: Martins Fontes, 2000.

BALOG, Frank D. The Scottish enlightenment and the liberal political tradition. In: BLOOM, Allan (Org.). Confronting the constitution: 
the challenge to Locke, Montesquieu, Jefferson, and federalists from utilitarianism, historicism, marxism, freudianism, pragmatism, existentialism... Washington: The AEI Press, 1990.

BARRERA, Guillaume. Les lois du monde: enquête sur le dessein politique de Montesquieu. Paris: Gallimard, 2009.

BAUN, Alan. Montesquieu and social theory. Oxford: Pergamon Press, 1979.

BENOIT-SMULLYAN, Emile. An outline of the history of political theory: part II: Montesquieu to present. Boston: Student Outlines Company, 1957.

BERENKASSA, Georges. Montesquieu. Paris: Presses Universitaires de France, 1968.

BRÈTHE DE LA GRESSAYE, Jean. L'histoire de l'esprit des lois. In: MIRKINE-GUETZÉVITCH, Boris et al. La pensée politique et constitutionnelle de Montesquieu: bicentenaire de l'esprit des lois: 1748-1948. Paris: Recueil Sirey, 1952.

BUKHARIN, Nikolai. Historical materialism: a system of sociology. New York: Routledge, 2011.

DEDIEU, Joseph. Montesquieu et la tradition politique anglaise en France: les sources anglaises de l'Esprit des Lois. Paris: Librairie Victor Lecoffre, 1909.

DUNNING, William Archibald. A history of political theories: from Luther to Montesquieu. New York: The Macmillan Company, 1928.

FINNIS, John. Lei natural e direitos naturais. São Leopoldo: Editora Unisinos, 2006.

FUSIL, Casimir Alexandre. Montesquieu: pages choisies. v. 1. Paris: Librairie Larousse, [s.d.].

GOYARD-FABRE, Simone. La philosophie du droit de Montesquieu. Paris: Libraire C. Klincksieck, 1973.

HERNÁNDEZ MARCOS, Maximiliano. Carl Gottlieb Svarez y la disolución del derecho natural en Alemania. In: Artículos de la Biblioteca Saavedra Fajardo de Pensamiento Político Hispánico. Murcia: Faculdad de Murcia, [s.d.].

HULLIUNG, Mark. Montesquieu and the old regime. Berkeley: University of California Press, 1976. 
O Historicismo Jurídico do Pensamento Montesquiano...

IGLESIAS, María del Carmen. El pensamiento de Montesquieu. Madrid: Alianza Universidad, 1984.

MARKOVITS, Francine. Montesquieu: le droit et l'histoire. Paris: Librairie Philosophique J. Vrin, 2008.

MAZZACANE, Aldo. Savigny e la storiografia giuridica tra storia e sistema. Napoli: Liguori, 1983.

MISES, Ludwig von. Marxism unmasked: from delusion to destruction. New York: Foundation for Economic Education, 2006.

MONTESQUIEU, Charles-Louis de Secondat, Barão de. De l'esprit des lois. v. 1. Paris: Flamarion, 1979.

PELAEZ, Francisco J. Contreras. Savigny y el historicismo jurídico. Madrid: Tecnos, 2005.

SAVIGNY, Friedrich Carl von. Of the vocation of our age for legislation and jurisprudence. Tradução de Abraham Hayward. London: Littlewood, 1831.

STAROBINSKI, Jean. Montesquieu. Ciudad de México: Fondo de Cultura Económica, 1989.

TOMÁS DE AQUINO, São. Suma de teología: parte I-II. t. 2. Madrid: Biblioteca de Autores Cristianos, 1989.

UEHARA, Yukio. Les idées de nature et d'histoire dans la théorie juridique de Montesquieu. In: GOYARD-FABRE, Simone (Org.). Cahiers de philosophie politique et juridique: la pensée politique de Montesquieu. Caen: Centre de Publications de l'Université de Caen, 1985.

VALLET DE GOYTISOLO, Juan. Montesquieu: leyes, gobiernos y poderes. Madrid: Civitas, 1986.

VERNIÈRE, Paul. Montesquieu et l'esprit des lois ou la raison impure. Paris: Société d'Édition d'Enseignement Supérieur, 1977.

WILFERT, Joël. Montesquieu: ou la hantise du despotisme. In: GRATELOUP, Léon-Louis (Org.). Les philosophes: de Platon à Montesquieu. v. 1. Paris: Hachette, 1985. 


\section{Hermenêutica Filosófica e Direito: Contribuições Teóricas}

Philosophical Hermeneutics and Law: Theoretical Contributions

Luíza Kitzmann Krug*

Resumo: Este artigo objetiva explorar as contribuições teóricas da Hermenêutica Filosófica ao Direito brasileiro. A discussão é contextualizada através da abordagem da superação da metafísica clássica pelo giro ontológico-linguístico. Realiza-se a análise da crise de paradigmas de dupla-face vigente da dogmática jurídica brasileira, representada pela crise do paradigma liberal-individualista-normativista e do paradigma da filosofia da consciência. Com base nos filósofos Martin Heidegger e Hans-Georg Gadamer, realiza-se um estudo da questão interpretação do Direito por meio da Hermenêutica Filosófica, trabalhando-se os conceitos de pré-compreensão, applicatio e tradição. Demonstra-se de que maneira a Hermenêutica Filosófica é uma alternativa viável de interpretação do Direito brasileiro, especialmente no que tange à jurisdição constitucional. Ao final, realiza-se a análise de julgados para verificar a extensão da inserção das teses abordadas no âmbito do Supremo Tribunal Federal.

Palavras-chave: Hermenêutica Filosófica. Metafísica. Giro Ontológico-Linguístico. Jurisdição Constitucional. Supremo Tribunal Federal Brasileiro.

Abstract: This article aims to explore the theoretical contributions of Philosophical Hermeneutics to Brazilian Law. The debate is contextualized through the approach of the overcoming of classical metaphysics by the linguistic-ontological turn. It is carried out the analysis of the double-front paradigm crises that is taking place

* Universidade Federal do Rio Grande. 
in the Brazilian legal dogmatic, represented by the crises of the liberal-individualistic-normative paradigm and of the philosophy of conscience paradigm. Based on the works of the philosophers Martin Heidegger and Hans-Georg Gadamer, it is carried out a study of the matter of interpretation of Law through the Philosophical Hermeneutics, working up the concepts of preunderstanding, applicatio and tradition. It is shown in which way the Philosophical Hermeneutics is a viable alternative of interpretation of Brazilian Law, especially in what concerns constitutional jurisdiction. At the end, it is carried out the analysis of legal cases in order to verify the extension of insertion of the approached thesis in the realm of the Brazilian Supreme Court.

Keywords: Philosophical Hermeneutics. Metaphysics. Linguistic-Ontological Turn. Constitutional Jurisdiction. Brazilian Federal Supreme Court.

\section{Introdução}

No meio jurídico, uma constante preocupação é a que concerne à interpretação. Na esteira desta problemática, considerando-se ainda o papel fundamental da Constituição no Direito brasileiro, importa buscar uma maneira de confrontarem-se os dispositivos ordinários com a normativa constitucional que se demonstre adequada ao contexto constitucionalista vigente. Até porque, "[...] uma Constituição nova [...] exige novos modos de análise ${ }^{\prime 1}$, ou seja, em tempos de constitucionalismo democrático, não se pode admitir que uma decisão que se diga constitucionalmente adequada dependa de juízos pessoais ou subjetivismos

1 STRECK, Lenio Luiz. Hermenêutica jurídica e $(m)$ crise: uma exploração hermenêutica do Direito. 10 ed. rev. atual. e ampl. Porto Alegre: Livraria do Advogado Editora, 2011. p. 80. 
morais com pretensão corretiva do Direito. Essa é a finalidade do presente estudo, qual seja apontar um modo que se possa traduzir uma atuação judicial (democrática) dentro do programa constitucional.

Neste intuito, encontra-se inspiração no seguinte questionamento de Streck: "Por que o pensar dos juristas seria diferente do pensar do filósofo? Por que o jurista teria um diferente 'acesso' à 'realidade'?" 2 . Conclui, ainda, o autor que "nada está a indicar que o direito tenha 'ficado de fora' ou que possa estar 'blindado' aos influxos dessas verdadeiras revoluções copernicanas que atravessaram a filosofia ao longo de mais de dois mil anos da história ocidental."3

Com este estímulo, adentra-se o âmbito do pensamento filosófico para a busca de uma solução à problemática interpretativa. Destarte, pretende-se demonstrar, através deste trabalho, de que forma a Hermenêutica Filosófica apresenta-se como um caminho a ser seguido pelos juristas na empreitada do processo interpretativo, especialmente no que tange à jurisdição constitucional e à avaliação da constitucionalidade das normas.

Para tanto, abordar-se-á de início a questão do giro linguístico-ontológico, passando-se em seguida à exposição do pensamento filosófico de Heidegger e Gadamer. Ao final, é realizada uma breve análise de alguns julgados do Supremo Tribunal Federal para verificar a extensão da inserção das teses ora analisadas no âmbito da corte constitucional brasileira.

2 STRECK, Lenio Luiz. O que é isto - decido conforme minha consciência? 2. ed. rev. e ampl. Porto Alegre: Livraria do Advogado, 2010. p. 10.

3 STRECK, O que é isto, op. cit., p. 18. 


\section{A Aplicação da Lei (Interpretação) e Viragem Linguística}

Na sua obra Verdade e Método, o filósofo Hans-Georg Gadamer afirma que aplicar a lei é, necessariamente, um ato interpretativo. O autor rejeita a ideia de que seja possível promulgar uma sentença por um mero ato de subsunção ${ }^{4}$. Na perspectiva de uma Hermenêutica Filosófica, não é admissível que o fato se subsuma à norma de maneira automática. Para o autor, são inseparáveis a compreensão, a interpretação e, por sua vez, a aplicação. ${ }^{5}$ É indispensável, e até mesmo inevitável, a ocorrência do processo interpretativo.

Ocorre que, no meio jurídico, este entendimento não é unânime. Sob outra perspectiva teórica, admite-se a dicotomia subsunção/interpretação, cindindo-se os casos em que ocorre a simples aplicação da lei ao caso em tela (subsunção) daqueles em que é necessária a interpretação dos dispositivos legais aplicáveis. Esta ideia está presente nas teorias de autores como Herbert Hart ${ }^{6}$, Ronald Dworkin ${ }^{7}$ e Robert Alexy $^{8}$, os quais entendem possível a distinção entre casos fáceis (easy cases) e casos difíceis (hard cases).

4 GADAMER, Hans-Georg. Verdade e método: traços fundamentais de uma hermenêutica filosófica. Tradução de Flavio Paulo Meurer. Revisão da tradução de Enio Paulo Giachini. 2. ed. Petrópolis: Vozes, 1998. p. 490.

5 GADAMER, op. cit., p. 459.

6 HART, Herbert Lionel A. O conceito de direito. Pós-escrito organizado por Penélope A. Bulloch e Joseph Raz. Tradução de Antônio de Oliveira Sette-Câmara; revisão da tradução de Marcalo Brandão Cipolla; revisão técnica de Luiz Virgílio Dalla-Rosa. São Paulo: Editora WMF Martins Fontes, 2009.

7 DWORKIN, Ronald. Levando os direitos a sério. Tradução de Nelson Boeira. 3. ed. São Paulo: Editora WMF Martins Fontes, 2010. passim.

8 ALEXY, Robert. Teoria dos direitos fundamentais. Tradução de Virgílio Afonso da Silva. São Paulo: Malheiros, 2008. passim. 
Nesta perspectiva, denominam-se casos fáceis aqueles nos quais se entende desnecessária a interpretação dos dispositivos normativos envolvidos na sua solução. Isto pressupõe a anterior existência de uma norma que resolva o caso, havendo o encaixe perfeito entre a conduta humana e o texto legal. O trabalho do julgador seria de tão somente verificar a existência da norma e sua aplicação ao caso em análise, através da subsunção do fato à norma.

Os casos difíceis, por sua vez, constituem-se em casos nos quais não é observada a existência de norma anterior que se encaixe perfeitamente ao caso. Ou não existem normas aplicáveis, ou, existindo, estas estão em conflito, tornando nebulosa a determinação da norma a ser aplicada por subsunção. Neste sentido, é a análise de Dworkin:

O positivismo jurídico fornece uma teoria dos casos difíceis. Quando uma ação judicial específica não pode ser submetida a uma regra de direito clara, estabelecida de antemão por alguma instituição, o juiz tem, segundo tal teoria, o "poder discricionário" para decidir o caso de uma maneira ou de outra. ${ }^{9}$

Também no direito pátrio, há autores que defendem a tese de que, na clareza da lei, desnecessária a interpretação, sendo Washington de Barros Monteiro a principal referência nesse sentido. Tal corrente é caracterizada pelo brocardo jurídico lex clara non indiget interpretatione. ${ }^{10}$

Defende-se, a contrario sensu, que o processo interpretativo ocorra em todos os casos, perspectiva também defendida por Francisco Motta, que dispõe:

9 DWORKIN, op. cit, p. 127.

${ }^{10}$ STRECK, Hermenêutica jurídica e $(m)$ crise, op. cit., p. 118. 
Não nos parece hermeneuticamente correta a distinção entre casos fáceis e casos difíceis que, queiramos ou não, está presente em Dworkin. Um caso é apenas um caso, e será "fácil" ou "difícil" de acordo com o intérprete que com ele se confrontar. Na verdade, um caso "difícil" é apenas um caso não compreendido, até porque quando um caso é corretamente compreendido, a interpretação "desaparece", não nos perguntamos mais por ela. ${ }^{11}$

Isto porque, diante da mudança paradigmática estabelecida pelo giro ontológico-linguístico, o qual veio para superar a metafísica clássica, passou-se a entender que o Direito, assim como o mundo, se dá na e pela linguagem, sendo desta indissociável. Enquanto, na metafísica clássica, acreditava-se que os sentidos estavam contidos nas coisas, 12 no âmbito do giro, superou-se o esquema sujeito-objeto para dar lugar a um esquema sujeito-sujeito. Isto é, passou-se a entender-se que a construção do conhecimento ocorre através do uso da linguagem. Ocorre que, na concepção de Streck, "[...] o campo jurídico brasileiro continua sendo refratário a essa viragem linguística". ${ }^{13}$

Para o autor, o Direito brasileiro estaria vivendo uma crise paradigmática de dupla-face, estando em crise não um, mas dois paradigmas. O primeiro seria o paradigma do modelo liberal-individualista-normativista, enquanto o segundo, o paradigma epistemológico da filosofia da consciência. Tal problemática estaria gerando, segundo o referido autor, um Direito alienado da sociedade. ${ }^{14}$

${ }^{11}$ MOTTA, Francisco José Borges. Levando o direito a sério: uma crítica hermenêutica ao protagonismo judicial. 2. ed. rev. e ampl. Porto Alegre: Livraria do Advogado, 2012. p. 75, nota de rodapé n. 187.

12 STRECK, O que é isto, op. cit., p. 13.

13 STRECK, Hermenêutica jurídica e $(m)$ crise, op. cit., p. 71.

${ }^{14}$ STRECK, Hermenêutica jurídica e (m) crise, op. cit., p. 97. 
Cabe referir que a denominada crise do modelo liberal-individualista-normativista do direito se revela na medida em que o direito brasileiro foi desenvolvido de forma a atender tão somente as relações de cunho privado. Isto é, o direito não está preparado para as questões atinentes aos direitos transindividuais. Esta crise de modelo acarretou que institutos importantes como o mandado de injunção e a substituição processual, trazidos pela Constituição Federal de 1988, não fossem aplicados em sua total eficácia, diante da falta de preparo por parte da dogmática jurídica em lidar com institutos que contrariem o modelo individualista.

Ainda no contexto da crise do modelo liberal-individualista-normativista, reside a problemática da não superação do positivismo normativista por parte do Direito brasileiro. Isto se dá em função da má diferenciação entre os conceitos de positivismo exegético (sintático) e positivismo normativista (semântico) por parte da dogmática jurídica. Com isso, o neoconstitucionalismo tornou-se uma espécie de continuação do positivismo. ${ }^{15}$

Deve-se esclarecer tal distinção. Por positivismo exegético, pode-se entender o positivismo primitivo, o qual tinha por característica a separação entre direito e moral, bem como fundava-se na proibição de interpretar. É de referir que esta ideia ainda persiste no imaginário jurídico, haja vista o exposto a respeito da aplicação por subsunção e da desnecessidade de interpretação na clareza da norma. Já o positivismo normativista tem por base a concepção de que não é possível realizar-se um fechamento semântico do direito. Com isso, esta forma do positivismo entendeu a interpretação

${ }^{15}$ STRECK, Hermenêutica jurídica e(m) crise, op. cit., p. 69, 78-79. 
como um problema menor, delegado aos aplicadores do direito. A preocupação reside, portanto, na questão da validade das normas. ${ }^{16}$

Quanto a isto, Streck entende que Kelsen foi mal interpretado no que tange ao entendimento de que este teria autorizado a discricionariedade interpretativa. $\mathrm{O}$ que Kelsen teria afirmado, em sua obra Teoria Pura do Direito, seria que a aplicação da lei como um ato de vontade do juiz seria uma fatalidade. Sendo inevitável, este autor não teria se preocupado em investigar essa questão. Isso não é dizer que o autor recomendou ou mesmo autorizou este agir por parte dos juízes. Não compreendendo corretamente este ponto, teriam os juristas absorvido tal discricionariedade como uma forma de correção do direito, dadas as insuficiências que este apresentaria. ${ }^{17}$

Delineada a crise do modelo liberal-individualista-normativista, passa-se o enfoque à denominada filosofia da consciência. De forma a demonstrar o pensamento metafísico, Streck, ao abordar Platão, exemplifica:

O Sócrates platônico (aparentemente) não rompe inteiramente com Crátilo e nem com Hermógenes, mas defende uma posição que concilia as precedentes. De fato, se os nomes são criados pelo nomoneta (ou onomaturgo de Platão), eles são uma convenção, como pretendiam os sofistas. Mas se existe uma adequação natural entre o nome e a coisa, é porque de alguma forma ambos participam de um referencial comum, tese defendida por Crátilo. Entre os dois polos (Crátilo e Hermógenes), deliberadamente postos no diálogo para propiciar a apresentação de uma tese intermediária, Platão começa a esconder o ser, ao trabalhar

\footnotetext{
${ }^{16}$ STRECK, Hermenêutica jurídica e(m) crise, op. cit., p. 48-51.

${ }^{17}$ STRECK, Hermenêutica jurídica e (m) crise, op. cit., p. 77.
} 
com a concepção de que é possível saber o que seja a coisa sem o uso da linguagem. Segundo a tese platônica, a palavra é tomada como representação da coisa. Quando o nomoneta ou o onomaturgo (dador de nomes) estabelece os nomes para as coisas, ele não o faz segundo sua própria vontade, mas segundo um modelo ideal (inato) ao qual ele não tem acesso direto, e que orienta, de alguma maneira, suas escolhas. (grifo do autor) ${ }^{18}$

Observa-se que, no trecho supracitado, Platão propõe a possibilidade de compreensão dos objetos sem o uso da linguagem. A linguagem, assim, seria mero instrumento para representar a coisa, a qual seria acessível diretamente, sem necessidade de intermediação. A mudança paradigmática evidenciada pela alteração terminológica (de metafísica para ontologia) consiste na alteração do esquema sujeito-objeto para um esquema que privilegia a relação sujeito-sujeito. É nisso que consiste o giro ontológico-linguístico (linguistic turn). Conforme indicado acima, o pensamento filosófico desenvolve-se no sentido de deixar de acreditar na existência de uma essência para as coisas. O acesso não se dá de forma direta aos objetos, não sendo possível extrair destes a essência. Pelo contrário, entende-se, como citado anteriormente, que o mundo só pode ser entendido, só é revelado na e pela linguagem, isto é, através da linguagem.

Segundo Streck, este paradigma, denominado filosofia da consciência, acaba por ser rompido pelo linguistic turn, caracterizado pelo ingresso do mundo prático na filosofia:

Pode-se afirmar que, no linguistic turn, a invasão que a linguagem promove no campo da filosofia transfere o próprio conhecimento para o âmbito da linguagem, onde o mundo se descortina; é na linguagem que se dá a ação; é

${ }_{18}$ STRECK, Hermenêutica jurídica e $(m)$ crise, op. cit., p. 154. 
na linguagem que se dá o sentido (e não na consciência de si do pensamento pensante). $O$ sujeito surge na linguagem e pela linguagem, a partir do que se pode dizer que o que morre é a subjetividade "assujeitadora", e não o sujeito da relação de objetos. (grifo do autor) ${ }^{19}$

$\mathrm{O}$ autor sintetiza esta questão dizendo que "[...] a viragem ontológico-linguística é o raiar da nova possibilidade de constituição do sentido". ${ }^{20}$ Ocorre que o sentido passa a ser constituído através de uma construção linguística, argumentativa. Há uma atribuição de sentido por parte do intérprete. A verdade ou inverdade não mais é verificável em comparação com a realidade presente na essência do objeto. No contexto da filosofia da linguagem, o importante não é propriamente o objeto em si considerado, mas o que diz a respeito desse objeto. ${ }^{21}$ Dessa forma, é através da linguagem que se possibilita o acesso ao objeto. A linguagem é, portanto, condição de possibilidade.

É possível apontar dois tipos de manifestação do paradigma da filosofia da consciência, também chamado de paradigma da subjetividade. O primeiro seria explícito, quando se assume que o ato de julgar reflete um ato de vontade, bem como quando, mesmo de maneira implícita, baseiam-se em uma interpretação individual (solipsista). O segundo seria composto por adeptos das teorias da argumentação jurídica, a exemplo de Habermas e Alexy, já que tais teorias, para Streck, não deixam de ser dependentes da discricionariedade judicial. $^{22}$

\footnotetext{
${ }^{19}$ STRECK, O que é isto, op. cit., p. 14-15.

${ }^{20}$ STRECK, O que é isto, op. cit., p. 16.

${ }^{21}$ STRECK, Hermenêutica jurídica e $(m)$ crise, op. cit., p. 71.

${ }^{22}$ STRECK, O que é isto, op. cit., p. 23-24
} 
Ainda no contexto da crise de paradigmas ora delineada, considera-se que a sua persistência no âmbito jurídico guarda íntima relação com aquilo que Luis Alberto Warat denomina de senso comum teórico dos juristas. Segundo o autor, este conceito refere-se às "condições implícitas de produção, circulação e consumo das verdades nas diferentes práticas de enunciação e escritura do Direito." ${ }^{23}$, sendo caracterizado pela reprodução de valores através da atribuição de sentidos não explicados pelos operadores do direito. ${ }^{24}$ Isto é, no meio jurídico são propagadas teses e doutrinas sem adequada fundamentação teórica, as quais são reproduzidas sem o devido filtro crítico por parte da comunidade jurídica.

Complementando sua crítica, Streck indaga: “[...] a pergunta que se opõe é: onde ficam a tradição, a coerência e a integridade do Direito? Cada decisão parte (ou estabelece) 'um grau zero de sentido'?". ${ }^{25}$ Tal questionamento procura demonstrar a ausência de superação do paradigma da filosofia da consciência, em que Direito e sociedade estão à disposição das conviç̧ões individuais de cada julgador, muitas vezes na contramão do que foi democraticamente produzido - validamente referendado pela Constituição.

\footnotetext{
${ }^{23}$ WARAT, Luis Alberto. Introdução geral ao direito I - Interpretação da lei: temas para uma reformulação. Porto Alegre: Fabris, 1994. p. 13.

${ }^{24}$ STRECK, Hermenêutica jurídica e (m) crise, op. cit., p. 83-84.

25 STRECK, O que é isto, op. cit., p. 27.
} 


\section{As Contribuiç̧̃es de Heidegger e Gadamer}

De forma a concretizar a noção de que a Hermenêutica Filosófica ${ }^{26}$ é especialmente relevante para a interpretação e aplicação do Direito, importante abordar os pensamentos dos filósofos Martin Heidegger e Hans-Georg Gadamer, os quais contribuíram sobremaneira para a ruptura do paradigma da filosofia da consciência e propuseram uma nova forma de pensar as ciências do espírito, a partir da já referida centralidade da linguagem.

Para romper com o esquema sujeito-objeto, Heidegger propõe em sua principal obra, intitulada Ser e tempo, aquilo que chama de uma ontologia fundamental. Fundamental não no sentido de uma superontologia, como aclarado por Casanova, mas como uma forma de questionar a possibilidade de ser desenvolvida uma ontologia, um estudo acerca do ser. Esta ontologia fundamental heideggeriana teria, por sua vez, três subprojetos: a destruição da história da ontologia, o desenvolvimento de uma hermenêutica da faticidade e o desenvolvimento de uma analítica existencial. ${ }^{27}$

Segundo Casanova, "Ser e tempo inicia-se, em outras palavras, com a constatação de que o problema central de toda ontologia, o significado daquilo que é, do ser, do ser do ente, não foi resolvido no interior da história da ontologia." ${ }^{28}$

\footnotetext{
${ }^{26}$ Importante observar que Heidegger e Gadamer optam por denominações diferentes para abordar a questão hermenêutica. Enquanto Heidegger a utiliza a expressão Filosofia Hermenêutica, Gadamer prefere a expressão Hermenêutica Filosófica, por considerar haverem diferenças entre seu pensamento e o de Heidegger. Para efeitos deste trabalho, adota-se a expressão Hermenêutica Filosófica por considerar-se que Gadamer vem para aprofundar a filosofia desenvolvida por Heidegger, agregando a ela a importante noção de tradição.

27 CASANOVA, Marco Antônio. Compreender Heidegger. Petrópolis: Vozes, 2009. p. 79. ${ }^{28}$ Ibidem, p. 76
} 
Destarte, Heidegger aborda três conceitos interdependentes, quais sejam: ser, ente e Dasein. A respeito do conceito de ser, Heidegger afirma sua complexa determinação, nas palavras que seguem:

No solo da arrancada grega para interpretar o ser, formou-se um dogma que não apenas declara supérflua a questão sobre o sentido do ser como lhe sanciona a falta. Pois se diz: "ser" é o conceito mais universal e o mais vazio. Como tal, resiste a toda tentativa de definição. Esse conceito mais universal e, por isso, indefinível prescinde de definição. Todo mundo o emprega constantemente e também compreende o que ele, cada vez, pretende designar. (grifo meu) ${ }^{29}$

Observa-se que Heidegger, neste ponto, contorna a questão da conceituação do ser, alegando ser este indefinível. Contudo, o próprio autor faz uma ressalva: “[...] a impossibilidade de definir o ser não dispensa a questão de seu sentido, ao contrário, justamente por isso a exige" ${ }^{30}$ Assim, o objeto de estudo não é propriamente a conceituação do ser, mas seu sentido a cada momento. A temporalidade, pois, "[...] possibilita o projeto do Dasein como questionador do ser." Daí intitular-se a obra Ser e tempo. ${ }^{31}$

A ideia do ente é, por sua vez, decorrente da noção de ser, sendo que ambos os conceitos são complementares. Heidegger aponta que "[...] o ser é sempre o ser de um ente". ${ }^{32}$ Pode-se, a partir disso, referir que o ser tem uma relação de caráter indissociável com o ente, como se aquele estivesse

${ }^{29}$ HEIDEGGER, Martin. Ser e tempo. Volume I. Tradução de Márcia de Sá Cavalcante. 4. ed. Petrópolis: Vozes, 1993. p. 27.

${ }^{30}$ HEIDEGGER, op. cit., p. 29.

${ }^{31}$ SER E TEMPO. In: HUISMAN, Denis. DICIONÁRIO de obras filosóficas. Tradução de Ivone Castilho Benedetti. São Paulo: Martins Fontes, 2000. p. 497-499.

32 HEIDEGGER, op. cit., p. 35. 
neste contido. Heidegger prossegue, relatando que “[...] o que resulta como interrogado na questão do ser é o próprio ente" (grifo do autor). Conclui ao afirmar que ente é "[...] tudo de que falamos, tudo que entendemos, com que nos comportamos dessa ou daquela maneira, ente é também o que e como nós mesmos somos". ${ }^{33}$

Para Zimmerman, “Dasein significa o local onde o ser ocorre" ${ }^{34}$ Este termo é traduzível pelas expressões ser-aí ou pre-sença. A respeito disso, Casanova afirma:

O termo "ser-aí" designa em um primeiro momento simplesmente o ser do homem. No entanto, ele não se mostra apenas como mais uma definição que irá incontornavelmente se juntar ao longo rol das definições cunhadas no interior da história do pensamento ocidental. Quase como se pudéssemos dizer: ser-aí é o conceito heideggeriano de homem. Não, não e mais um não! O emprego do termo ser-aí indica no presente contexto uma transformação radical do modo mesmo de pensar o ser do homem. Antes de mais nada, é preciso ter em vista o fato de ser-aí não ser um termo cunhado por Heidegger a partir da pergunta: o que é o homem? O termo ser-aí inviabiliza desde o princípio a colocação de uma tal pergunta, na medida em que possui um modo de ser que o distingue fundamentalmente de todos os entes marcados pela presença de propriedades quididativas. $^{35}$

O referido autor afirma ainda que o Dasein seria um ente em "[...] princípio absorvido na facticidade incontornável de seu mundo, ao mesmo tempo em que seja marcado por uma relação originária e indissolúvel com o ser." . ${ }^{36}$ Cabe

\footnotetext{
${ }^{33}$ HEIDEGGER, op. cit., p. 32.

${ }^{34}$ ZIMMERMAN, Michael E. apud STRECK, Hermenêutica jurídica e(m) crise, op. cit., p. 251.

${ }^{35}$ CASANOVA, op. cit., p. 89.

${ }^{36}$ CASANOVA, op. cit., p. 86-87.
} 
frisar que o "ser-aí" ocupará, no âmbito do giro, o lugar outrora pertencente ao sujeito da relação sujeito-objeto. Dessa forma, o sujeito deixa de ser um observador descontextualizado e capaz de acessar diretamente o objeto de análise, passando a chamar-se Dasein. Este está, pois, inserido na faticidade do mundo, sendo partícipe de uma relação sujeito-sujeito, realizada na e pela linguagem, através da qual tem acesso ao mundo.

Heidegger, com a obra Hermenêutica da Faticidade, altera o objeto da hermenêutica, a qual deixa de ter como objeto exclusivo a interpretação textual, passando a incluir a faticidade. A respeito da faticidade, pode-se dizer que esta representa, para o ser-aí, o passado, sendo o selo histórico nele imprimido, enquanto o futuro seria um ter-que-ser que caracteriza seu modo-de-ser. ${ }^{37}$. Com isso, percebe-se que a faticidade é um importante elemento do processo de compreensão do ser inserido no Dasein (ser-aí). Esta compreensão ocorre inserida na faticidade do mundo, sofrendo as influências do mundo prático.

No entender de Heidegger, a superação da metafísica (e o ingresso no paradigma da linguagem) dá-se a partir da não entificação do ser, visto que este não pode ser confundido com o ente, no que Streck pontua que:

A diferença ontológica é o suporte do ser e do ente. No ente é pensado e dito o ser. O ente não existe como ente, ou seja, o ente não existe - no sentido de sua existência - sem estar junto ao ser (o ente só é no seu ser e o ser é sempre ser-em, ser-junto (Sein-bei) ${ }^{38}$

\footnotetext{
${ }_{37}$ STRECK, Hermenêutica jurídica e(m) crise, op. cit., p. 239.

38 STRECK, Hermenêutica jurídica e $(m)$ crise, op. cit., p. 260.
} 
Falar em diferença ontológica é dizer justamente que ser e ente não são conceitos completamente distintos. Se o fossem, o ser seria um novo ente, e tal diferença seria simplesmente ôntica (entre entes) e não ontológica (entre ser e ente). Como será abordado na sequência, um exemplo de diferença ontológica é a diferença entre texto (ente) e norma (ser), visto que a todo o texto se atribui uma norma. Pode-se dizer que tal diferença "[...] consiste na transcendência do ser-aí, ou seja, no seu confronto com o ser mediante a compreensão deste" ${ }^{39}$ Para Stein, esta diferenciação é, "[...] ao lado do círculo hermenêutico, um dos dois teoremas fundamentais heideggerianos para superar a metafísica" ${ }^{40}$

Tendo-se claro, portanto, que o ser não é o ente, deve-se ter ainda em vista que o Dasein é um ente em interação com o mundo, o qual tem uma estrutura simbólica, sendo que, para Heidegger, o modo de ser do Dasein é a compreensão. Compreensão esta que se dá no Dasein de forma pré-ontológica. ${ }^{41}$

Ernildo Stein, ao abordar as teses centrais da obra Ser e tempo, afirma que uma destas, ao focar-se na clarificação da questão do ser, concluiria que tal esclarecimento somente se daria a partir do recurso ao Dasein, uma vez que este, o homem, seria o único ente capaz de efetivamente compreender o ser. ${ }^{42}$

Para Heidegger, "[...] toda interpretação que se coloca no movimento de compreender já deve ter compreendido

\footnotetext{
${ }^{39}$ DIFERENÇA ONTOLÓGICA. In: ABBAGNO, op. cit., p. 276.

40 STEIN apud STRECK, Hermenêutica jurídica e $(m)$ crise, op. cit., p. 258-259.

${ }^{41}$ STRECK, Hermenêutica jurídica e (m) crise, op. cit., p. 249-251.

${ }^{42}$ STEIN, Ernildo. Seis estudos sobre ser e tempo. 2. ed. Petrópolis: Vozes, 1990. p. 11.
} 
o que se quer interpretar." 43 Isto é, "[...] no Dasein reside uma pré-compreensão" ${ }^{44}$, referida por Stein como sendo uma maneira de "[...] ver a compreensão como uma estrutura antecipadora". ${ }^{45}$ Streck complementa ao afirmar que este sentido articulado pela interpretação é aquele já entendido como uma possibilidade no momento da compreensão. $\mathrm{Na}$ abertura da compreensão, o sentido é, portanto, aquele que tem a possibilidade de ser articulado. ${ }^{46}$ Nas palavras de Heidegger:

A interpretação de algo como algo funda-se, essencialmente, numa posição prévia, visão prévia, e concepção prévia. A interpretação nunca é apreensão de um dado preliminar, isenta de pressuposições. Se a concreção da interpretação, no sentido da interpretação textual exata, se compraz em se basear nisso que "está" no texto, aquilo que, de imediato, apresenta como estando no texto nada mais é do que a opinião prévia, indiscutida e supostamente evidente, do intérprete. Em todo princípio de interpretação, ela se apresenta como sendo aquilo que a interpretação necessariamente já "põe", ou seja, que é preliminarmente dado na posição prévia, visão prévia e concepção prévia. ${ }^{47}$

Esta compreensão, para Stein, nunca se dará de forma pura. Isso porque a compreensão sempre estará ligada ao modo-de-ser no mundo do Dasein, à sua faticidade, conforme já abordado. Para o autor, é neste ponto que se situa o núcleo do processo hermenêutico heideggeriano. ${ }^{48}$ Cabe aqui retomar que o pensamento heideggeriano se funda no rompimento

\footnotetext{
${ }^{43}$ HEIDEGGER, op. cit., p. 209.

${ }^{44}$ STRECK, Hermenêutica jurídica e $(m)$ crise, op. cit., p. 252.

${ }^{45}$ STEIN, Ernildo. Aproximações sobre hermenêutica. Porto Alegre: Edipucrs, 1996. p. 59.

46 STRECK, Hermenêutica jurídica e $(m)$ crise, op. cit., p. 252.

${ }^{47}$ HEIDEGGER, op. cit., p. 207.

${ }^{48}$ STEIN, Aproximações sobre hermenêutica, op. cit., p. 61.
} 
da estrutura sujeito-objeto. Dessa forma, a compreensão do Dasein ocorre através da linguagem, sendo esta condição de possibilidade para a compreensão. Isto é aclarado por Streck da seguinte forma:

A linguagem, então, é totalidade; é abertura para o mundo; é, enfim, condição de possibilidade. Melhor dizendo, a linguagem, mais do que condição de possibilidade, é constituinte e constituidora do saber, e, portanto, do nosso modo-de-ser-no-mundo, que implica as condições de possibilidades que temos para compreender e agir. Isso porque é pela linguagem e somente por ela que podemos ter um mundo e chegar nesse mundo. Sem linguagem não há mundo, enquanto mundo. (grifo do autor) ${ }^{49}$

Tal informação é complementada por Stein ao afirmar que é apenas através da linguagem que se dará o acesso aos objetos..$^{50}$ Estes, por sua vez, não são os objetos puramente considerados, a exemplo do que se dava com a noção de mundo das ideias de Sócrates. Os objetos são, assim, considerados enquanto algo. São analisados, portanto, de forma contextualizada.

Partindo do filosofar de Heidegger, Gadamer veio a afirmar que "[...] ser que pode ser compreendido é linguagem". ${ }^{51}$ Para Stein, este enunciado é o de maior importância na obra de Gadamer, salientando que

[...] isso que ele diz no fim do livro, "ser que pode ser compreendido é linguagem", já está pressuposto desde o começo porque desenvolve a ideia de que estamos envolvidos na linguagem, da qual determinamos a verdade ou a falsidade das proposições. Existe, portanto, uma experiência da linguagem, de que a linguagem é mais do

\footnotetext{
${ }^{49}$ STRECK, Hermenêutica jurídica e(m) crise, op. cit., p. 254-255.

50 STEIN, Aproximações sobre hermenêutica, op. cit., p. 60.

${ }^{51}$ GADAMER apud STEIN, Aproximações sobre hermenêutica, op. cit., p. 73.
} 
que nós mesmos, na medida em que a linguagem é parte daquilo em que estamos enraizados, e é parte de nossa faticidade. (grifo do autor) ${ }^{52}$

Chris Lawn equipara a importância deste enunciado ao seguinte dizer de Heidegger: "A linguagem é a casa do ser $^{\prime \prime 53}$. Para este autor, embora a questão da linguagem pareça supérflua em um primeiro momento, visto que esta teria o simples objetivo de comunicar, a questão configura-se de maneira mais complexa. Ocorre que, conforme este indica, o que Gadamer pretende com este enunciado é demonstrar que, mesmo que existam linguagens e sentimentos não verbais, como a música, a arte e a própria dor, não existe nada que, após compreendido, não possa ser expresso através da palavra. ${ }^{54}$

Gadamer, como Heidegger, trabalha com a noção de pré-compreensão antecipadora do sentido. Esta pré-compreensão dá-se a partir dos chamados preconceitos, termo utilizado pelo filósofo sem sua carga semântica negativa, para significar as concepções prévias do intérprete ao acessar o texto. Estas concepções podem ser, por sua vez, valorizadas tanto positiva quanto negativamente. ${ }^{55}$ A este respeito, para o filósofo:

Quem quiser compreender um texto realiza sempre um projetar. Tão logo apareça um primeiro sentido no texto, o intérprete prelineia um sentido do todo. Naturalmente que o sentido apenas se manifesta porque quem lê o texto lê a partir de determinadas expectativas e na perspectiva

\footnotetext{
52 STEIN, Aproximações sobre hermenêutica, op. cit., p. 73.

${ }^{53}$ HEIDEGGER apud LAWN, Cris. Compreender Gadamer. Tradução de Hélio Magri Filho. 2. ed. Petrópolis: Vozes, 2010. p. 111.

${ }^{54}$ LAWN, op. cit., p. 111-115.

${ }^{55}$ GADAMER, op. cit., p. 407.
} 
de um sentido determinado. A compreensão do que está posto no texto consiste precisamente na elaboração desse projeto prévio, que, obviamente, tem que ir sendo constantemente revisado com base no que se dá conforme se avança na penetração do sentido. (grifo meu) ${ }^{56}$

Existe, pois, a possibilidade de o intérprete calcar-se em falsos preconceitos, os quais acabam por gerar uma compreensão equivocada. Apenas com base nos pré-juízos verdadeiros é construída a compreensão. Fazer esta distinção exige a aliança entre uma consciência formada hermeneuticamente e uma consciência histórica. Ter consciência dos próprios pré-juízos implica, por sua vez, sua suspensão. Conforme Streck, “[...] na medida em que um pré-juízo nos determina, não o conhecemos nem o pensamos como um juízo". Isto é, apenas é possível visualizar um preconceito como tal no momento em que este é suspenso. Esta suspensão é possível através do encontro do intérprete com a tradição, conceito que será explicitado na sequência. ${ }^{57}$

A pré-compreensão identifica-se com a noção de círculo hermenêutico, na medida em que, ao acessar o texto, o intérprete já está situado no horizonte de sentido que este lhe abre. ${ }^{58}$ Falar em círculo hermenêutico é abordar o caráter circular da compreensão, visto que o homem (Dasein) apenas compreende a si mesmo ao compreender o ser, embora necessite já compreender-se para compreendê-lo. ${ }^{59} \mathrm{Na}$ interpretação, isso quer dizer que esta é revista a todo instante

\footnotetext{
${ }^{56}$ GADAMER, op. cit., p. 402.

57 STRECK, Hermenêutica jurídica e (m) crise, op. cit., p. 333.

58 SOARES, Ricardo Maurício Freire. Hermenêutica e interpretação jurídica. São Paulo: Saraiva, 2010. p. 11.

${ }^{59}$ STRECK, Hermenêutica jurídica e(m) crise, op. cit., p. 240.
} 
pelo leitor, à medida que este vai se abrindo aos significados que o texto lhe propõe, no que Streck esclarece que,

[...] para Gadamer, aquele que pretende compreender não pode entregar-se desde o princípio à sorte de suas próprias opiniões prévias e ignorar a mais obstinada e consequentemente possível opinião do texto. Aquele que pretende compreender um texto tem que estar em princípio disposto a que o texto lhe diga algo. Uma consciência formada hermeneuticamente tem que se mostrar receptiva desde o início para a condição do texto. Entretanto, esta receptividade não pressupõe nem neutralidade nem autocancelamento, senão que inclui uma matizada incorporação das próprias opiniões prévias e pré-juízos. (grifo do autor ${ }^{60}$

Destarte, tem-se que o intérprete dialoga com o texto a partir de suas concepções prévias e é por meio deste diálogo que a compreensão do texto acontece. Como referido, é necessário que o leitor tenha a intenção de deixar que o texto lhe diga alguma coisa, caso contrário, não ocorrerá o necessário diálogo entre o horizonte do Dasein e o horizonte histórico, acabando prejudicada a própria compreensão.

Gadamer, segundo Streck, entende que o objeto da pré-compreensão será a tradição, a qual possui uma dimensão linguística, uma vez que é transmitida através da linguagem, primeiramente de maneira verbalizada e posteriormente através da escrita. Prossegue, afirmando que ao compreender-se um fenômeno passado, ocorre o que se chama de uma fusão de horizontes, sendo a presença de um horizonte histórico condição de possibilidade para este fenômeno. Este horizonte histórico, por sua vez, será eventualmente superado através dessa fusão de horizontes. ${ }^{61}$

\footnotetext{
${ }^{60}$ STRECK, Hermenêutica jurídica e $(m)$ crise, op. cit., p. 263.

${ }^{61}$ STRECK, Hermenêutica jurídica e (m) crise, op. cit., p. 265-266.
} 
Finalmente, conclui-se a abordagem ao pensamento gadameriano retomando-se a questão, já apontada no início deste artigo, da impossibilidade da compreensão sem aplicação. No entender de Gadamer, "[...] a tarefa da interpretação consiste em concretizar a lei em cada caso, isto é, em sua aplicação". ${ }^{62}$ Não é possível, como realizava-se na hermenêutica clássica, interpretar por partes (subtilitas intelligendi, subtilitas explicandi, subtilitas applicandi). Todos os momentos da interpretação concebidos pelas concepções clássicas da hermenêutica ocorrem em um momento único, chamado por Gadamer de applicatio ${ }^{63}$ indicando Streck que:

Negar que a norma é produto da interpretação do texto e que interpretar é sempre um ato aplicativo (applicatio), implica negar a temporalidade. Os sentidos são temporais. A diferença (que é ontológica) entre texto e norma ocorre na incidência do tempo. Daí a impossibilidade de reprodução de sentidos, como se o sentido fosse algo que pudesse ser arrancado dos textos (da lei, etc.). [...] O texto será sempre "já normado" pelo intérprete. É por isso que um mesmo texto dá azo a várias normas. A norma será sempre, assim, resultado de um processo de atribuição de sentido (Sinngebung) a um texto. (grifo do autor) ${ }^{64}$

Prossegue, afirmando que o simples ato de acessar um texto, de lê-lo, já gera a atribuição de um sentido. Neste caso, de uma norma ao texto. Isto se dá, conforme aludido neste artigo, dentro do círculo hermenêutico e em função do fenômeno da pré-compreensão antecipadora do sentido do texto. Por este processo, o intérprete já delineia o sentido do texto no momento de sua leitura, tomando por base seus pré-juízos, seus preconceitos e, em última análise, a tradição. Em

\footnotetext{
${ }^{62}$ GADAMER, op. cit., p. 489.

63 STRECK, Hermenêutica jurídica e (m) crise, op. cit., p. 271-272.

${ }^{64}$ STRECK, Hermenêutica jurídica e $(m)$ crise, op. cit., p. 357.
} 
seguida (mas no mesmo momento, já que a interpretação não se dá por etapas), da fusão de horizontes realizada entre a sua pré-compreensão baseada na tradição e o horizonte de sentido do texto exsurge a norma presente naquele texto. ${ }^{65}$

Destarte, texto e norma possuem uma diferença ontológica, da mesma forma que se dá a diferenciação entre ser e ente. Não há, pois, uma cisão entre texto e norma. Estes não se constituem em entes distintos. Da mesma maneira que todo ser é um ser de um ente, todo texto contém, ou melhor, a todo texto é atribuível uma norma através da applicatio. Tem-se, portanto, que a "[...] norma é, assim, o texto aplicado/ concretizado." 66

\section{Hermenêutica e Jurisdição Constitucional}

Expostas essas considerações a respeito do filosofar de Gadamer e Heidegger, passa-se a investigar até que ponto a Hermenêutica Filosófica vem se inserindo no contexto das decisões do Supremo Tribunal Federal. Neste intuito, é oportuno trazer à baila a seguinte afirmação de Streck:

Vê-se, pois, que qualquer resposta correta é necessariamente uma resposta adequada à Constituição. Uma norma - que é sempre o produto da interpretação de um texto (que, por sua vez, é sempre evento) - somente é válida se estiver de acordo com a Constituição. Portanto, o intérprete deve, antes de tudo, compatibilizar a norma com a Constituição, conferindo-lhe a totalidade eficacial. [...] Por isso, todo ato interpretativo (portanto, aplicativo) é ato de jurisdição constitucional. Mesmo quando o problema parece estar resolvido mediante a aplicação da regra, deve o intérprete

\footnotetext{
${ }^{65}$ STRECK, Hermenêutica jurídica e $(m)$ crise, op. cit., p. 357.

${ }^{66}$ STRECK, Hermenêutica jurídica e $(m)$ crise, op. cit., p. 361.
} 
- e se trata de um dever constitucional que tem a sua dimensão dita pelo nível de seus pré-juízos legítimos (ou ilegítimos) - verificar se o princípio que subjaz à regra não aponta em outra direção. (grifo do autor) (grifo meu) ${ }^{67}$

O objetivo desta investigação coaduna-se com o enunciado supracitado. Busca-se verificar a existência de julgados que contenham uma preocupação hermenêutica na hora de interpretar. Através de pesquisa no banco de dados do website do STF (www.stf.jus.br), tanto na parte de pesquisa de jurisprudência como no setor Constituição e o Supremo, foram inseridos termos como: Gadamer, Heidegger, hermenêutica, Hermenêutica Filosófica, hermenêutica jurídica etc.

Aponta-se, desde logo, que a tarefa de buscar nos julgados do STF referências à Hermenêutica Filosófica não foi tarefa simples. A pesquisa do termo Gadamer resultou apenas em dois julgados que referiam este autor na seção da doutrina, sendo um destes a Arguição de Descumprimento de Preceito Fundamental no 46, de 2009, relatada pelo Ministro Eros Grau, e o outro o Recurso Extraordinário n⿳o 197917, de 2002, relatada pelo Ministro Maurício Corrêa. Além disso, a pesquisa pela expressão Hermenêutica Filosófica também obteve como resultado a ADPF no ${ }^{-46}$, uma vez que o título do livro de Gadamer presente nas referências do julgado continha a expressão.

Por outro lado, a pesquisa pelo autor Heidegger não logrou resultado algum. Como forma de comparação, realizou-se a busca pelo autor Robert Alexy, sendo encontrados 36 acórdãos, 04 decisões monocráticas, 10 decisões da presidência, além de 05 informativos referindo o autor.

${ }^{67}$ STRECK, Lenio Luiz. Verdade e consenso: constituição, hermenêutica e teorias discursivas. 4. ed. São Paulo: Saraiva, 2012. p. 314-315. 
A partir destes dados, é possível avaliar, ao menos de forma preliminar, que o autor Robert Alexy possui muito mais inserção no âmbito do Supremo do que os autores enfocados neste artigo. Isso demonstra, pelo menos em parte, que as teses defendidas por estes não foram, até o momento, acolhidas pelo tribunal constitucional brasileiro.

Na pesquisa pelo termo hermenêutica, todavia, foi possível encontrar mais resultados positivos. Foram localizados 139 acórdãos, 330 decisões monocráticas, 9 decisões da presidência, 2 questões de ordem e 38 informativos com referência ao termo. A questão que se levanta, contudo, é de que este vocábulo é demasiadamente genérico, sendo por vezes utilizado como sinônimo do termo interpretação. Logo, a pesquisa não possui a capacidade de demonstrar, sem a análise detida de cada resultado, se estes indicam efetivamente que os julgados em tela abordem a questão da Hermenêutica Filosófica.

Já a procura pela expressão hermenêutica jurídica resultou em interessante julgado, o qual estava localizado no setor de informativo de jurisprudência. Trata-se de Agravo Regimental no Habeas Corpus no $84486 / \mathrm{SP}^{68}$, relatado pelo Ministro Celso de Mello. No acórdão, encontra-se uma referência ao termo hermenêutica jurídica, em uma citação, realizada pelo Min. Celso de Mello, do autor José Frederico Marques, a qual consiste no seguinte:

O sentido da cláusula constitucional inerente à soberania dos veredictos do Júri não se confunde, em nosso direito positivo, com a noção de absoluta irrecorribilidade das

${ }^{68}$ BRASIL, Supremo Tribunal Federal. Habeas Corpus no 84486 AgR/SP (01/06/2010). Disponível em: <http://redir.stf.jus.br/paginadorpub/paginador. jsp?docTP=AC\&docID=612986>. Acesso em: 29 mar. 2012. 
decisões proferidas pelo Conselho de Sentença. Bem o demonstrou, já na vigência da Constituição de 1946 - que igualmente consagrara, de modo explícito, essa prerrogativa institucional do Júri - o saudoso JOSÉ FREDERICO MARQUES ("A Instituição do Júri", vol. I, p. 40/41, item n. 3, 1963, Saraiva): 'Tal exegese, além de condenada pela hermenêutica jurídica, tem, ao demais, outro ponto fraco: dá ao vocábulo soberania o sentido absoluto e rígido de poder sem contraste e supremo. (grifo meu) ${ }^{69}$

Embora o autor citado pelo Min. Celso de Mello utilize de forma genérica a expressão hermenêutica jurídica, percebe-se, através da leitura do julgado, a existência de um resgate da tradição jurídica a respeito da questão em debate, concernente à soberania das decisões do Tribunal do Júri. Através deste resgate, o ministro logrou demonstrar que o dispositivo do Código de Processo Penal atacado foi recepcionado pela Constituição Federal de 1988, não ferindo, portanto, a soberania do júri.

Outro julgado que há de ser citado é o referente ao Habeas Corpus no 82.424-2/RS ${ }^{70}$, conhecido como caso Ellwanger, cujo acordão foi relatado pelo Min. Maurício Corrêa. Neste ponto, cabe referir um trecho da ementa:

HABEAS-CORPUS. PUBLICAÇÃO DE LIVROS: ANTI-SEMITISMO. RACISMO. CRIME IMPRESCRITÍVEL. CONCEITUAÇÃO. ABRANGÊNCIA CONSTITUCIONAL. LIBERDADE DE EXPRESSÃO. LIMITES. ORDEM DENEGADA. [...] 3. Raça humana. Subdivisão. Inexistência. Com a definição e o mapeamento do genoma humano, cientificamente

${ }^{69}$ BRASIL, Supremo Tribunal Federal. Habeas Corpus no 84486 AgR/SP (01/06/2010). Disponível em: <http://redir.stf.jus.br/paginadorpub/paginador .jsp?docTP=AC\&docID=612986>. Acesso em: 29 mar. 2012.

${ }^{70}$ BRASIL, Supremo Tribunal Federal. Habeas Corpus no 82.424-2/RS (17/09/2003) Disponível em: <http://redir.stf.jus.br/paginadorpub/paginador. jsp?docTP=AC\&docID=79052>. Acesso em: 29 mar. 2012. 
não existem distinções entre os homens, seja pela segmentação da pele, formato dos olhos, altura, pelos ou por quaisquer outras características físicas, visto que todos se qualificam como espécie humana. Não há diferenças biológicas entre os seres humanos. Na essência são todos iguais. (grifo meu).

Nesse, o STF optou, por maioria, pela interpretação do caso a partir da tradição internacional, deixando de lado a tese da ponderação de Robert Alexy. O caso consistiu na publicação de livros de caráter antissemita, sendo o pedido de liberdade pautado no argumento eminentemente semântico de que a discriminação aos judeus não constitui o crime de racismo, visto que este grupo não comporia uma raça propriamente dita. Dessa forma, aplicar-se-ia o instituto da prescrição à espécie.

Contudo, o entendimento do tribunal foi diverso, entendendo, a partir do voto do Ministro Maurício Corrêa, pela imprescritibilidade do delito. Em seu voto, alegou o ministro:

A questão, como visto, gira em torno da exegese do termo racismo inscrito na Constituição como sendo crime inafiançável e imprescritível. Creio não se lhe poder emprestar isoladamente o significado usual da raça como expressão simplesmente biológica. Deve-se, na verdade, entendê-lo em harmonia com os demais preceitos com ele inter-relacionados, para daí mensurar o alcance de sua correta aplicação constitucional, sobretudo levando-se em conta a pluralidade de conceituações do termo, entendido não só à luz de seu sentido meramente vernacular, mas também do que resulta de sua valoração antropológica e de seus aspectos sociológicos.

Pode-se afirmar que este julgado se coaduna com os pressupostos da Hermenêutica Filosófica. Em seu voto, o Min. Maurício Corrêa, a exemplo do que ocorreu no julgado 
anteriormente citado, buscou na tradição internacional a solução para o que seria aparentemente um conflito entre os princípios da liberdade de expressão e da proibição do racismo. Acertado o ministro ao entender, conforme descrito na ementa, que não existe aquilo que se convencionou chamar de raças, visto que todas as pessoas seriam membros da mesma raça: a raça humana.

Resgatou-se, no caso, a tradição a partir da pré-compreensão do intérprete, cuja mente não é tábula rasa. Vê-se que a história é "[...] a condição prévia para que o ente seja um ser-no-mundo" ${ }^{71}$ É notória a discriminação sofrida pelo povo judaico durante o período nazista, não sendo possível que se autorize, em um Estado que pretende respeitar os Direitos Humanos, a distorção e até mesmo a negação destes fatos históricos. Ignorar a história da sociedade global seria dar azo à possibilidade de repetição dos equívocos passados.

É por este motivo que assiste razão à Streck ao afirmar que o julgador não possa tomar atitudes solipsistas no momento do julgamento. ${ }^{72} \mathrm{O}$ decidir conforme sua própria consciência, ignorando a tradição do Direito, bem como, no caso, a própria história da humanidade, é produzir, como já referido no início deste artigo, um direito alienado da sociedade.

${ }_{71}$ STRECK, Hermenêutica jurídica e $(m)$ crise, op. cit., p. 264.

72 STRECK, O que é isto, op. cit., p. 33. 


\section{Considerações Finais}

Este artigo buscou evidenciar a relevância da Hermenêutica Filosófica para a interpretação no Direito. Para tanto, mergulhou-se no fenômeno do giro-ontológico-linguístico, para demonstrar a centralidade da linguagem para a construção do conhecimento, o qual abriu as portas para a filosofia da linguagem e superação da metafísica clássica. Então, foram abordados alguns conceitos envolvidos nos pensamentos dos filósofos Heidegger e Gadamer, quais sejam as noções de Dasein, pré-compreensão, tradição e círculo hermenêutico.

Considera-se que as teses desenvolvidas por Heidegger e Gadamer no âmbito da filosofia da linguagem são de grande valia para a compreensão do fenômeno jurídico brasileiro. Defende-se que a Hermenêutica Filosófica constitui-se em um caminho adequado para a interpretação do Direito brasileiro, especialmente no que tange à esfera constitucional.

A partir deste trabalho, é possível considerar a tradição, nos moldes concebidos por Gadamer, como uma alternativa viável e qualificada para que o jurista pense o Direito. Com o resgate da tradição, evita-se que em cada caso se parta do zero, que se construa um pensamento novo totalmente desvinculado das decisões anteriores e da doutrina consolidada no país. Através desse resgate, torna-se possível superar o paradigma da filosofia da consciência e o fenômeno do solipsismo judicial.

As teses gadamerianas e heideggerianas possuem aplicabilidade no Direito pátrio, conforme percebido através da análise do Habeas Corpus no 84486/SP e do Habeas Corpus nº 82.424-2/RS. No entanto, tais teses possuem inserção limitada 
no âmbito do Supremo Tribunal Federal, especialmente se comparadas com as teorias da argumentação jurídica. Com isto, entende-se oportuna a busca por uma maior divulgação e difusão dos pressupostos hermenêuticos no âmago jurídico brasileiro, de forma a concretizar a superação da metafísica e a entrada na filosofia da linguagem no contexto jurídico nacional.

\section{Referências}

ABBAGNO, Nicola. Dicionário de filosofia. 4. ed. São Paulo: Martins Fontes, 2000.

ALEXY, Robert. Teoria dos direitos fundamentais. Tradução de Virgílio Afonso da Silva. São Paulo: Malheiros, 2008. 669p.

BRASIL, Supremo Tribunal Federal. Habeas Corpus nº 82.424-2/RS (17/09/2003). Disponível em: <http://redir.stf.jus.br/paginadorpub/ paginador.jsp?docTP=AC\&docID=79052> . Acesso em: 29 mar. 2012.

BRASIL, Supremo Tribunal Federal. Habeas Corpus no 84486 AgR/ SP (01/06/2010). Disponível em: <http://redir.stf.jus.br/paginadorpub/paginador.jsp?docTP=AC\&docID $=612986>$. Acesso em: 29 mar. 2012.

CASANOVA, Marco Antônio. Compreender Heidegger. Petrópolis: Vozes, 2009. 244p.

DWORKIN, Ronald. Levando os direitos a sério. Tradução de Nelson Boeira. 3. ed. São Paulo: Editora WMF Martins Fontes, 2010. 568p.

GADAMER, Hans-Georg. Verdade e método: traços fundamentais de uma hermenêutica filosófica. Tradução de Flavio Paulo Meurer. Revisão da tradução de Enio Paulo Giachini. 2. ed. Petrópolis: Vozes, 1998. 731p.

HART, Herbert Lionel. O conceito de direito. Pós-escrito organizado por Penélope A. Bulloch e Joseph Raz. Tradução de Antônio de Oliveira Sette-Câmara; revisão da tradução de Marcalo Brandão Cipolla; revisão técnica de Luiz Virgílio Dalla-Rosa. São Paulo: Editora WMF Martins Fontes, 2009. 
HEIDEGGER, Martin. Ser e tempo. Volume I. Tradução de Márcia de Sá Cavalcante. 4. ed. Petrópolis: Vozes, 1993. 325p.

HUISMAN, Denis. Dicionário de obras filosóficas. Tradução de Ivone Castilho Benedetti. São Paulo: Martins Fontes, 2000.

LAWN, Cris. Compreender Gadamer. Tradução de Hélio Magri Filho. 2. ed. Petrópolis: Vozes, 2010. 208p.

MOTTA, Francisco José Borges. Levando o direito a sério: uma crítica hermenêutica ao protagonismo judicial. 2. ed. rev. e ampl. Porto Alegre: Livraria do Advogado, 2012.

SOARES, Ricardo Maurício Freire. Hermenêutica e interpretação jurídica. São Paulo: Saraiva, 2010.

STEIN, Ernildo. Seis estudos sobre ser e tempo. 2. ed. Petrópolis: Vozes, 1990. 132p.

1996. 112p.

. Aproximações sobre hermenêutica. Porto Alegre: Edipucrs,

STRECK, Lenio Luiz. O que é isto - decido conforme minha consciência? 2. ed. rev. e ampl. Porto Alegre: Livraria do Advogado, 2010. 118p.

. Hermenêutica jurídica e $(m)$ crise: uma exploração hermenêutica do Direito. 10. ed. rev. atual. e ampl. Porto Alegre: Livraria do Advogado Editora, 2011. 420p.

- Verdade e consenso: constituição, hermenêutica e teorias discursivas. 4. ed. São Paulo: Saraiva, 2012. 639p.

WARAT, Luis Alberto. Introdução geral ao direito I - Interpretação da lei: temas para uma reformulação. Porto Alegre: Fabris, 1994.

Submissão: 10/06/2013 Aceito para Publicação: 14/08/2013 



\section{Regulação da Prestação de Serviços Bancários: no Limiar entre o Agravamento e a Contenção da Crise Atual no Âmbito do Mercosul}

Bank Service Regulation: on the Brink Between the Aggravation and the Contention of the Crisis in the Realm of Mercosur

Andréa Rocha Postiga*

Resumo: Os recentes acontecimentos no cenário internacional têm demonstrado a fragilidade das grandes economias face a falhas em seus sistemas bancário e financeiro. A falta de supervisão adequada nessa esfera fez com que uma grave crise se desencadeasse em escala internacional, resultando no enfraquecimento não só da economia daqueles países considerados os focos da crise como também causando efeitos no cenário econômico mundial. A adoção de medidas de supervisão e de controle estabelecidas pelos padrões internacionais é essencial nesse contexto, em que a integração regional tem importante papel, devendo ser vista como via de fortalecimento para a superação das adversidades do sistema. $\mathrm{O}$ Mercosul, como bloco regional, ainda está atrasado nessa matéria, reflexo talvez de seu processo incompleto de integração. O objetivo deste artigo é demonstrar a necessidade de que o sistema bancário no âmbito do Mercosul empreenda as medidas necessárias para oferecer amparo mais efetivo a seus membros, a fim de que se disponha de uma regulação efetiva em nível regional, capaz

* Universidade Federal do Rio Grande do Sul. 
Regulação da Prestação de Serviços Bancários...

de evitar que as crises alcancem efeitos catastróficos nos Estados do bloco, cujas economias estão em desenvolvimento.

Palavras-chave: Sistema Bancário. Mercosul. Integração Regional. Crise. Sistema Financeiro.

Abstract: Recent events in the international scenario have been demonstrating the fragility of big economies when facing faults in its banking and financial system. The lacking of adequate supervision in this realm caused the emergence of a severe crisis on a global scale, weakening not only the countries where it begun, but also producing its effects in the whole international context. The adoption of measures of control and supervision established by international standards is essential in such context, wherein the regional integration plays an important role, what should be seen as a means of strengthening in order to overcome systemic adversities. The Mercosur, as a regional institution, is well behind on this subject, which may be a reflection of its incomplete integration process. The aim of this paper is to demonstrate the need that the banking system in the Mercosur undertake the necessary measures in order to provide its members with a more effective protection, in order to dispose of an effective regulation in regional scale, one able to avoid that the crisis reach catastrophic effects in its member states, whose economies are developing.

Keywords: Banking System. Mercosur. Integration. Crisis. Financial System.

\section{Introdução}

O sistema bancário está no centro do funcionamento dos mercados mundiais. Esta fatia de serviços afeta de maneira direta os setores de crédito, captação, securitização e seguros, setores que sustentam a economia em qualquer parte do planeta. Seja na esfera pública, seja na privada, os 
bancos viabilizam trocas comerciais, investimentos, manutenção da estabilidade da moeda e a dinamização do ciclo de negócios (PALOMO; SANCHIS-PALACIO; GUTIÉRREZFERNÁNDEZ, 2011, p. 180).

Justamente em razão da vasta abrangência da atividade bancária e da potencial repercussão que perturbações e interferências importantes possam vir a ter, não só para o setor, mas para o restante da economia, exige-se o máximo de responsabilidade e prudência, para que o seu desempenho se dê de acordo com o esperado. As instituições financeiras exercem uma ampla gama de atividades que as expõe fortemente a inúmeros riscos, que devem ser minimizados pelo monitoramento de uma estrutura reguladora, para que seja mantida a estabilidade (CARNEIRO; VIVAN; KRAUSE, 2004, p. 2).

No âmbito europeu, por exemplo, as iniciativas integracionistas desde há muito identificaram a necessidade de uma atuação coesa neste setor. Nesse sentido, o mercado único foi articulado com o objetivo de abolir os obstáculos e de simplificar as regras existentes, de maneira a permitir a todos - indivíduos, consumidores e empresas - que extraiam o maior proveito possível das oportunidades criadas por este novo contexto (LOBO, 2004, p. 205). O acesso direto aos mercados dos 27 Estados-membros da União exige, contudo, determinadas condições para seu pleno funcionamento, tal como fora projetado (CAMPOS; CAMPOS, 2004, p. 523).

Apesar dos consideráveis avanços conquistados na consolidação e no desenvolvimento desse mercado, ainda são constatadas deficiências que dificultam seu funcionamento em determinadas áreas, como no sistema financeiro. 
A crise ora atravessada contribui para evidenciar as falhas presentes neste sistema, não só impedindo o bom funcionamento do mercado único, como também repercutindo em toda economia internacional. Questiona-se inclusive se não seria o momento de implementar uma nova regulação para resolução das questões que têm sido objeto recorrente de discussão nas recentes reuniões de cúpula da União Europeia.

Sendo o sistema bancário de natureza extraterritorial, como foi dito, a ausência de regulação adequada pode repercutir em todo sistema financeiro (HELLWIG, 2009, p. 201), o que se confirmou pelos últimos acontecimentos originados das sucessivas crises generalizadas. Por essa razão, sistemas bancários de credibilidade passam por abalos tremendos. A proposta de revisão do sistema europeu, profundamente afetado, revela-se um alerta para o Mercosul, tendo em vista as dimensões extraterritoriais e o vasto alcance das crises.

Ainda que no Mercosul não se tenha desenvolvido um sistema bancário tão integrado e harmonizado quanto o europeu, existe uma regulação no bloco para o setor. Ocorre que, a exemplo das demais matérias reguladas em seu âmbito, o que se observa atualmente é a inatividade dos atores responsáveis pela implementação das diretrizes estabelecidas. Este fator, contudo, carece de meios para que seja corrigido, justamente em razão do caráter do bloco (VIGEVANI; FAVARON; JÚNIOR; CORREIA, 2008, p. 5).

A relevância do presente estudo é notória, tanto em razão da atualidade do tema quanto em decorrência do caráter sistêmico de que é dotada a matéria, necessitando de efetiva atenção para o bom funcionamento dos mercados e, por conseguinte, para proteção das economias nacionais. 
Para tanto, é necessário revisar a sistemática adotada, permitindo-se verificar a existência de amparo para o aprimoramento da regulamentação da matéria e de sua efetividade no bloco. É imprescindível, nesse bojo, que se proceda a uma análise conjuntural do Mercosul, a fim de dizer se tal alteração teria os efeitos desejados para atravessar a crise da melhor forma possível.

Nesse intuito, o presente estudo está dividido em duas partes. Na primeira parte, é feita a contextualização dos serviços bancários, dentro do conceito de liberdade econômica fundamental no Mercosul, passando-se pela regulação legal sobre a qual se apoia e pela estrutura institucional de auxílio. Em um segundo momento do trabalho, direciona-se a atenção para a análise dos problemas existentes, de maneira a poder avaliar se as soluções recentemente apresentadas serão eficazes para conter o agravamento da crise e a geração de outras. Encerra-se o estudo com conclusões acerca de quais dessas mudanças deverão ser implementadas, levantando-se a hipótese de eventualmente virem a ser aplicadas também no âmbito do Mercosul.

Tomando-se a União Europeia como parâmetro de integração, apesar dos problemas apresentados recentemente, buscam-se respostas a problemas cuja repercussão se dá em nível global. Estando os Estados do Mercosul cada vez mais inseridos na cena internacional, como é o caso do Brasil, que a cada dia estreita seus laços comerciais, não apenas com a União Europeia, mas também com diversos outros Estados, sugere-se a busca de inspiração nos aspectos que tiveram êxito e a observância daqueles que, ao contrário, falharam (ou estão falhando), para que não sejam repetidas as mesmas falhas. 


\section{A Estrutura Financeira do Mercosul no Contexto da Integração Regional}

Antes de adentrar-se na abordagem do conteúdo deste ponto, propriamente dito, cabe consignar a opção realizada na atribuição do título desta parte do trabalho. Ao contrário do que se observa na União Europeia, dotada de um sistema bancário articulado por meio de uma regulamentação legal e de um aparato institucional correspondente, o Mercosul não dispõe de estrutura semelhante que justifique uma comparação. Por essa razão de impropriedade terminológica, optou-se aqui por fazer referência à estrutura financeira, termo que melhor define a organização aqui existente.

Segundo corretamente observa José María Fanelli (2008, p. 17), o estudo da integração financeira entre países do sul (ou considerados "países em desenvolvimento") deve ser realizado de forma diversa da análise realizada entre países do norte ou entre este e um do sul. Aponta, para tanto, um grupo de quatro características a serem tomadas em conta no que tange à mecânica desses sistemas nos países emergentes.

Primeiramente, refere que a aceleração do crescimento nesses países é meta constante, pois precisam crescer mais rápido do que os países desenvolvidos, para que consigam alcançar seus níveis de PIB e poder, assim, fazer frente a eles no mercado internacional; em segundo lugar, anota que os mercados financeiros desses Estados seriam incompletos e carentes de estruturas eficientes de governança para bancos e instituições financeiras; em terceiro lugar, menciona a existência de instituições fracas, o que, por seu turno, repercutiria na qualidade das regulações e da supervisão; por derradeiro, aponta que a integração com os mercados internacionais, apesar de avançada, apresenta deficiências. 
No que tange ao Mercosul, o autor propõe que antes de se proceder uma análise da integração financeira do bloco, que se tenha em mente a existência destes fatores determinantes para a compreensão da estruturação e evolução (se houve) do sistema bancário aqui presente, de modo a permitir-nos identificar as oportunidades e estratégias para que uma eventual reforma seja empreendida.

Agrega-se aqui o fato de que, em razão de sua estrutura intergovernamental (LORENTZ, 2001, p. 31), as disposições dos tratados e convenções celebrados pelos Estados-partes não poderão impor supremacia a outro ou mesmo induzir qualquer tipo de submissão a algum organismo capaz de colocar sua soberania à prova. O Mercosul encontra-se fundado sobre os pilares da cooperação, caracterizada pela soma das vontades nacionais, ao invés de ter por substrato a vontade comum. Nessa esteira, seu corpo de funcionários representa os interesses dos Estados-partes e as normas jurídicas produzidas no âmbito integracionista devem ser por estes internalizadas para que sejam capazes de produzir efeitos jurídicos. Disso decorre a inexistência de primazia da norma criada no bloco sobre o ordenamento jurídico nacional e de aplicabilidade direta das mesmas (POSTIGA, 2011, p. 51).

Inexistindo no âmbito do Mercosul qualquer regulamentação da matéria diretamente aplicável aos Estados, que seja proveniente do bloco, como ocorre na União Europeia, nem mesmo a previsão para fiscalização quanto à internalização desta normativa, a disciplina existente resume-se à adoção pelo bloco de normas internacionais, disciplinadas em convenções e conjuntos normativos e principiológicos 
por meio de resoluções ${ }^{1}$ e decisões ${ }^{2}$, para nortear a regulação bancária no âmbito interno dos Estados-partes, que são orientados a internalizar essas normas por meio de seus instrumentos nacionais.

Ao longo da última década, tentou-se, a partir da estrutura disponível, empreender esforços para reforma da arquitetura financeira do bloco, no sentido de serem adotadas melhores práticas e regras recomendadas nos padrões e códigos internacionais. Essas ações acabaram por resultar na busca da adequação da disciplina adotada pelo bloco à normativa internacional, para sua melhor inserção nos mercados globais (FANELLI, 2008, p. 32).

As crises financeiras atravessadas pelos Estados latinos, notadamente pelos setores bancários da Argentina e do Uruguai, somadas à ausência de fiscalização em nível institucional capaz de controlar a aplicação das regulações adotadas, contudo, contribuíram para a falta de uniformidade entre os Estados-partes, em sua observância, o que resultou nas disparidades entre as regulações adotadas nos Estados do bloco (BANCO CENTRAL DO BRASIL, 2006; 2007; 2008; 2009; 2010; 2011).

Tecidas as considerações acerca do contexto existente no Mercosul, direciona-se a análise para a estrutura organizada neste bloco para tratar do tema, bem como para a regulação que se apresenta para disciplinar a matéria.

No Mercosul, o órgão responsável pela elaboração e coordenação das políticas financeiras do bloco é o Subgrupo de Trabalho no 4 - Assuntos Financeiros (SGT4) (MERCOSUL,

\footnotetext{
1 Instrumentos provenientes do Grupo Mercado Comum (GMC).

2 Instrumentos pelos quais se manifesta o Conselho do Mercado Comum (CMC).
} 
1991; GRUPO MERCADO COMUM, 1995), coordenado pelos Bancos Centrais do Mercosul, é o órgão responsável pela realização do processo de integração financeira do bloco, tendo como objetivo final a criação de um mercado comum regional, contemplando os setores bancário, de seguros e de mercado de capitais. É composto por quatro comissões e por subcomissões. A comissão encarregada dos assuntos concernentes aos serviços bancários no Mercosul é a Comissão do Sistema Financeiro (CSF) e a Subcomissão de Demonstrações Contábeis (SDC) (BANCO CENTRAL DO BRASIL, 2012).

As decisões tomadas pelas comissões no sentido da adoção de Resoluções ou Decisões deverão obrigatoriamente ser objeto de consenso entre as autoridades dos Estados -partes do bloco, em razão do caráter intergovernamental do bloco. Os projetos são levados aos Coordenadores Nacionais, em que são analisados e revisados. Após aprovação pelos Coordenadores do SGT4, o projeto é encaminhado com cópias nas duas línguas oficiais do Mercosul (espanhol e português) ao Grupo Mercado Comum, juntamente com uma Recomendação dos Coordenadores Nacionais do SGT4, para que se aprove o projeto. $\mathrm{O}$ mesmo procedimento é aplicado aos acordos que, quando convergentes com os normativos internos, são incorporados automaticamente à legislação de cada Estado-parte sem a necessidade de trâmite pelos poderes legislativos (BANCO CENTRAL DO BRASIL, 2012).

Sob a responsabilidade dos Coordenadores Nacionais do SGT4, são elaborados os seguintes documentos: "Programa de trabalho do SGT4", sobre a periodicidade anual e consolidação pelo país no exercício da Presidência Pro Tempore; "Quadro comparativo de normas vigentes em matéria de regimes cambiais no Mercosul", com atualização semestral 
e consolidação pelo Brasil; e "Quadro de restrições a movimentos de capitais no Mercosul", cuja atualização é também semestral, consolidado pelo Uruguai. Ao final de cada Presidência Pro Tempore, é ainda elaborado, para encaminhamento ao GMC, o "Relatório de atividades do SGT4", descrevendo os principais trabalhos desenvolvidos durante o período.

A CSF é integrada pelos órgãos normativos dos Bancos Centrais dos Estados-partes do Mercosul, atua sempre que solicitada por algum órgão da estrutura institucional do Mercosul, no processo de negociação da liberalização progressiva dos serviços financeiros no Mercosul. É também o órgão responsável por fazer o acompanhamento relativo à internalização e à aplicação dos princípios e das normas básicas, estabelecidos pelo Comitê de Supervisão Bancária de Basileia, relativos à fixação dos níveis mínimos de capital com base nos ativos de risco (CONSELHO MERCADO COMUM, 1993), cuja adoção foi determinada pela Decisão n. - 10/93, pelo Conselho do Mercado Comum (CMC). Com o propósito de preservar a estabilidade dos sistemas financeiros do Mercosul, também é responsável pela realização de seminários e pelo desenvolvimento de atividades que facilitem a adoção dos "Princípios Básicos para uma Supervisão Bancária Eficaz (BANK FOR INTERNATIONAL SETTLEMENTS, 2004; CONSELHO MERCADO COMUM, 1994; BASEL COMMITTEE ON BANKING SUPERVISION, 2004)" nos países membros.

Este conjunto de princípios foi elaborado no bojo do Comitê da Basileia, que, por seu turno, não possui autoridade formal de supervisão internacional, de modo que suas conclusões não têm, nem pretendem ter, força legal. Seu objetivo é a elaboração de padrões de supervisão, bem como 
recomendações e princípios para as melhores práticas no mercado financeiro, na expectativa de que as autoridades de cada país adotem as respectivas medidas para implementá-las.

Nessa esteira, foi concluído no âmbito do Mercosul o projeto de cooperação técnica "Supervisão Global Consolidada", apoiado financeiramente pelo Banco Interamericano de Desenvolvimento (BID). O trabalho abrange o controle referente ao escopo legal e normativo relacionado com a supervisão bancária dos Estados-partes, os processos de ingresso e egresso do sistema financeiro, relacionados a autorizações, fusões ou cisões de instituições financeiras, e processo de supervisão direta e indireta, em bases individual e consolidada (BANCO CENTRAL DO BRASIL, 2012).

O SGT4, por meio da CSF, trabalha com o levantamento e estudo de atos normativos sobre a indústria bancária nos Estados-partes do Mercosul, com o propósito de identificar as assimetrias e avançar no processo de harmonização das normas que regulam os sistemas bancários, condição necessária para a futura conformação de um mercado comum. Sua atuação dá-se no sentido de preservar a estabilidade dos sistemas financeiros do Mercosul, pela promoção do intercâmbio de informações entre os Estados-partes acerca dos progressos realizados tendentes à harmonização e adoção de normas na área.

Os Bancos Centrais do Mercosul implementaram, em atenção às recomendações formuladas por meio da Decisão CMC № 10/93, um conjunto amplo de normativas no sentido da adequação de seus sistemas financeiros às normas prudenciais preconizadas pelo Comitê da Basileia sobre Regulamentação Bancária e Práticas de Supervisão. Em que pese os 
riscos existentes em cada sistema financeiro em particular, a CSF entendeu que já não mais se verificariam assimetrias significativas entre os parceiros quanto ao tema. Todavia, apesar das recomendações contidas na Decisão CMC № 12/94, ainda persistem diferenças importantes quanto aos princípios relativos à supervisão bancária global consolidada.

Em 26 de agosto de 1999, o Brasil e a Argentina firmaram um "Protocolo de Cooperação sobre Supervisão Bancária". O Paraguai, contudo, está examinando a possibilidade de firmar protocolos de mesmo teor com esses países e o Uruguai, bem como vem realizando avaliações de natureza jurídica sobre a matéria. A Argentina é responsável pela consolidação semestral do "Quadro Comparativo sobre o Cumprimento dos 25 Princípios Básicos para uma Supervisão Bancária Eficaz", nos moldes propostos pelo Comitê da Basileia sobre Regulamentação Bancária e Práticas de Supervisão.

Argentina e Brasil já dispõem dos resultados das avaliações realizadas em ambos os países no marco da iniciativa Financial Sector Assessment Program (FSAP), implementada pelo Fundo Monetário Internacional (FMI) e pelo Banco Mundial (BIRD). Paraguai e Uruguai participam igualmente da iniciativa, dependendo, ainda, das avaliações finais. Essas avaliações servirão como base para a elaboração, no âmbito do Mercosul, de um "Cronograma de Adequação para o Cumprimento dos 25 Princípios Básicos para uma Supervisão Bancária Eficaz".

Subcomissão de Demonstrações Contábeis (SCDC) encarregou-se dos assuntos referentes à classificação de devedores, provisionamento mínimo e harmonização de critérios para fracionamento de risco de crédito, para os quais, por 
determinação da Resolução GMC № 01/96, os Estados-partes deverão adotar as normas básicas estabelecidas pela comunidade financeira internacional para a matéria (BANCO CENTRAL DO BRASIL, 2012).

Visando a aprofundar os avanços já alcançados quanto à harmonização nos critérios para o modelo de informação contábil, haja vista ainda subsistirem diferentes critérios relativos ao alcance que se atribui em cada país sobre a situação das instituições financeiras, e de forma a conferir maior disciplina e confiança aos respectivos sistemas financeiros, $\mathrm{o}$ GMC, por meio da Resolução GMC № 20/01, instruiu os Estados-partes a adotar para seus sistemas financeiros as regras de transparência informativa recomendadas pelo Comitê da Basileia sobre Regulamentação Bancária e Práticas de Supervisão (BANCO CENTRAL DO BRASIL, 2012).

Nesse sentido, os órgãos supervisores do Mercosul pretendem buscar a convergência para os padrões internacionais, para a harmonização das demonstrações contábeis nos sistemas financeiros da região.

O SGT4 serve-se também do trabalho do Grupo de Serviços, a quem também presta assessoria nas negociações para liberalização progressiva dos serviços financeiros. O trabalho desempenhado pelo Grupo de Serviços é coordenado pelos Ministros das Relações exteriores dos Estados-partes, que é a instância decisória e responsável pelo trabalho de viabilizar a realização do compromisso firmado no Protocolo de Montevideo sobre o Comércio de serviços no $\mathrm{Mercosul}^{3}$, no sentido de completar o programa de

3 O Protocolo de Montevidéu responde pelo compromisso fixado no Artigo I do Tratado de Assunção em favor da livre circulação de bens, serviços e fatores produtivos entre os países do Mercosul. 
liberalização progressiva dos serviços, incluindo os serviços financeiros, mediante a adoção progressiva de compromissos específicos nos vários setores.

O processo de liberalização progressiva dos mercados financeiros no Mercosul, desenvolve-se, assim, com a harmonização de critérios para a classificação e definições de setores e subsetores a consignar nas Listas de Compromissos Específicos do Protocolo de Montevideo, as entradas "não consolidado ${ }^{4 \prime \prime}$ e a consolidação do status quo para atualização das listas. Uma vez harmonizados esses entendimentos e atualizadas as listas, são promovidos, na medida do possível, avanços na liberalização dos serviços (BANCO CENTRAL DO BRASIL, 2012).

A este propósito, as Listas de Compromissos firmadas no âmbito das Rodadas de Negociações do Protocolo de Montevideo (BANCO CENTRAL DO BRASIL, 2003; 2004) revelam-se de grande utilidade para avaliação dos níveis de harmonização atingidos até o momento, mostrando que a vasta maioria dos assuntos em pauta para serem harmonizados no âmbito dos serviços bancários transfronteiriços encontram-se ainda com a rubrica "não-consolidado" nas referidas listas. Nas hipóteses em que existe, contudo, algum tipo de regulação sobre o tema, esta apresenta-se em geral com uma série de restrições e requisitos à prestação do serviço em questão.

4 A inscrição "não consolidado" significa juridicamente que um Estado não está ofertando determinado setor ou subsetor, a natureza inicial do exercício consiste em saber o teor da regulamentação restritiva daquela atividade, ou se o setor não está regulamentado.

5 A consolidação do status quo, retratando a realidade normativa existente em cada um dos Estados-partes, significa oficializar junto aos parceiros a legislação sobre serviços efetivamente praticada no país. 
Na última Reunião dos Coordenadores Nacionais (SGT-4 SUBGRUPO DE TRABALHO N. 4 - ASSUNTOS FINANCEIROS, 2012), que teve lugar dos dias 7 a 11 de maio de 2012, foi levado a discussão o informe da Comissão de Sistema Financeiro (CSF), tratando sobre a situação atual em que se encontra a adequação às normas da Basileia entre os Estados do Mercosul. Os standards estabelecidos pelo Comitê concernentes à adequação do capital, aos princípios para uma supervisão bancária eficaz e à supervisão da atividade bancária transfronteiriço tem sido gradualmente implementados no âmbito do Mercosul.

Na reunião em questão, avaliou-se os níveis de implementação dessas normas em cada um dos Estados-partes do Mercosul, revelando sobretudo a discrepância entre os estágios de implementação dessas normas no Brasil e nos demais Estados, estando mais próxima a Argentina e apresentando níveis ainda pouco evoluídos, Paraguai e Uruguai (SGT-4 SUBGRUPO DE TRABALHO N. 4 - ASSUNTOS FINANCEIROS, 2012, p. 6). A Venezuela é também avaliada, mas ainda não apresenta progressos significativos.

A implementação dos novos padrões estabelecidos pelo Comitê de Basileia (Basileia III), para reforço dos mecanismos de prevenção de crises e elevação das exigências de capital mínimo para as instituições bancárias, também é pouco uniforme no âmbito do bloco, considerando que países como Paraguai e Uruguai não conseguiram ainda implementar as exigências dos padrões estabelecidos nos documentos Basileia I e II (BANK FOR INTERNATIONAL SETTLEMENTS, 2012).

O status da implementação dessas normas pelos Estados no âmbito do Mercosul pode também ser verificado a 
partir da análise do Quadro Comparativo de Normas (SGT-4 SUBGRUPO DE TRABALHO N. ${ }^{4}$ - ASSUNTOS FINANCEIROS, 2012, p. 5) ${ }^{6}$, instrumentos por meio dos quais os Estados-partes promovem intercâmbio de informações sobre a emissão de normas que são consolidadas, com data-base em dezembro de cada ano, que, por seu turno, revela ainda grandes assimetrias no tocante à incorporação desses padrões pelos Estados em suas legislações, fator este que dificulta as tentativas de estreitamento dos laços entre os setores bancários desses Estados (BANCO CENTRAL DO BRASIL, 2006; 2007; 2008; 2009; 2010; 2011).

Nessa esteira, observa-se a ausência de regulação tendente à harmonização no setor bancário no âmbito do bloco, permanecendo ainda diversos entraves à circulação desse serviço no âmbito do Mercosul, apontando novamente para a fragmentariedade de seu sistema financeiro. Com efeito, no Mercosul, devido à ausência de um critério de "equilíbrio geral", cada Estado tomou as suas atitudes para introdução de reformas e alterações nos regimes bancário e monetário, sem que fosse levada em conta a funcionalidade do todo. A este fator, soma-se o fato de os fluxos de capital

${ }_{6}$ A versão atualizada do quadro comparativo de normas que avalia os estágios de implementação mais recentes do Novo Acordo de Capital da Basileia, o cumprimento dos 25 Princípios Básicos de Supervisão bancária Eficaz e da harmonização das normas que regulam os sistemas bancários ainda não se encontra disponível no sitio de consulta do Mercosul, mas na XXXIV Reunião Ordinária do SGT-4 Assuntos Financeiros do Mercosul (Mercosul/SGT N. 4/Ata N. 02/2012 de 2012, Anexo VII), que teve lugar em 25 e 26 de outubro de 2012, os representantes, coordenadores nacionais e delegações dos Estados-parte apresentaram a evolução da aplicação das normas, inclusive com especial destaque à integração da Venezuela e aos compromissos por esta assumidos, tendo em vista que passou a integrar o bloco em junho de 2012. Disponível em: <http://www.bcb.gov.br/Rex/SGT4/Ftp/ ata_CSF_02_2012.pdf> e <http://www.bcb.gov.br/Rex/SGT4/Ftp/progr_CN_2013. pdf $>$ Acesso em: 10 dez. 2013. 
entre os Estados do Mercosul revelarem-se ainda muito pequenos, e a intenção de direcionar os investimentos para as trocas no âmbito interno do Mercosul por seus Estados -partes não parece constar de suas agendas de integração.

Devendo cada Estado adaptar-se de acordo com a sua realidade, o Brasil foi o Estado que acabou logrando maior êxito na consolidação de um sistema bancário articulado, tendo sobrevivido com menos danos às crises recentes. Da estrutura estudada, a realidade que se observa em todos os casos é a forte presença de bancos estrangeiros no setor bancário dos Estados do Mercosul, enquanto que os bancos privados nacionais permanecem fracos na Argentina e quase inexistentes no Uruguai. Disso decorre a desaparição do setor bancário destinado a setores específicos, em nichos regionais ou setoriais, deixando desamparados estes mercados. $\mathrm{O}$ Brasil, por seu turno, é o único Estado do bloco que se serve dos instrumentos financeiros de que dispõe de maneira ativa e em grande escala para condução da política industrial, a exemplo da ação do BNDES (Banco Nacional de Desenvolvimento) (FANELLI, 2008, p. 30).

Os resultados e os planos de trabalho do SGT4 que se ocupa das regras do jogo no plano financeiro são pobres e carecem de visibilidade dentro do bloco. De todo modo, nem mesmo no plano multilateral, logrou-se alcançar um posicionamento coordenado da parte dos Estados do Mercosul no cenário internacional, o que se reflete especialmente nas posições em sentidos totalmente opostos de Brasil e Argentina quanto à integração.

A questão que parece colocar-se ainda nesses países não concerne à aceleração do crescimento das finanças do 
Mercosul, ou à falta de iniciativa neste campo, mas sim à maneira pela qual se alcançar um desenvolvimento robusto, capaz de suportar as crises. A resposta para esta pergunta parece estar presente no caso observado na União Europeia, cuja conclusão foi a de que, para tanto, a qualidade da regulação e da supervisão são peças chaves nesse processo (FANELLI, 2008, p. 32), o que, na realidade, parece cada vez mais distante no Mercosul.

Nessa esteira, as linhas integracionistas ainda discutem se a integração financeira não teria potencial para atrair a atenção dos Estados-partes novamente para o processo de integração regional. Fanelli afirma que o aprofundamento da integração financeira poderia melhorar o desenvolvimento do Mercosul, na medida em que seria capaz de reduzir a volatilidade e a probabilidade da ocorrência de crises financeiras (FANELLI, 2008, p. 18). Para justificar a intensão de inverter a ordem que seria "natural" (ordem de integração identificada na União Europeia), argumenta que outros instrumentos de cooperação poderiam ser implementados antes.

Para José María Fanelli (2008, p. 14), se a integração regional oferecesse efetiva oportunidade para aprofundar os mercados financeiros dos Estados-partes do bloco e existisse a possibilidade de desenvolvê-lo a tal nível que não seria atingido isoladamente por cada Estado, haveria maior incentivo, para que desejassem pertencer ao bloco. Afirma, por outro lado, que eventual avanço na integração financeira teria efeitos de "retroalimentação", na medida em que estaria facilitando um processo de integração profunda em um mercado único. 


\section{Deficiências de Regulação no Setor Bancário do Mercosul}

São os mais diversos os pontos de vista identificados nos estudos realizados sobre qual seria a melhor opção para o Mercosul no tocante à regulação do sistema bancário. Como já foi referido neste artigo, a regulação bancária tem caráter sistêmico (CARNEIRO; VIVAN; KRAUSE; 2004, p. 21), exercendo papel primordial para manutenção da estabilidade financeira e para o bom funcionamento da economia. Como ensinam Studart e Hermann (2001, p. 104), a integração acarreta dois efeitos: um efeito quantitativo, que se traduz na ampliação dos mercados envolvidos, e um efeito qualitativo, consistente nas mudanças no perfil de concorrência e inserção externa do setor envolvido.

O que existe de fato atualmente no âmbito do Mercosul é a inter-relação entre quatro sistemas que guardam significativas diferenças entre si. Brasil e Argentina aproximam-se quanto às dimensões do sistema bancário, da mesma forma que ocorre entre Paraguai e Uruguai (MACEDO; GRANDES, 2005, p. 169). Entretanto, as diferenças atingem níveis mais profundos. A diversidade de estruturas identificadas nos quatro Estados do bloco, em especial com relação ao tamanho, à profundidade, à concentração e à importância do mercado de capitais afigura-se significativa (MENDONÇA, 2009). Os Estados compartilham, porém, experiências similares, tendo todos atravessado recentemente processos de liberalização e a crise financeira, que, na maioria dos casos, repercutiram especialmente no setor bancário.

Da análise da evolução do bloco, constata-se que entre os anos 1990 e 2000 a liberalização financeira teve papel 
primordial no desenvolvimento do bloco, na medida em que, aproveitando-se da conjuntura internacional favorável, conseguiu gerar condições favoráveis à estabilização de preços. No entanto, a fase seguinte não logrou em obter os mesmos resultados, de modo que a mobilização eficiente de recursos internos passou a desempenhar importante tarefa no crescimento do bloco. Para Studart, o desenvolvimento da economia do Mercosul, em 2000, estava a depender da capacidade de seus Estados-partes retomarem os níveis de acumulação e demanda interna e reduzirem suas taxas de desemprego (STUDART; HERMANN, 2001, p. 111).

A expectativa de que o setor financeiro fizesse parte desse processo de retomada, contudo, dependia da superação de importantes óbices à sua efetiva integração, ainda não superados no âmbito do Mercosul. Dentre os problemas à época identificados, destaca-se a questão concorrencial entre as instituições financeiras de menor porte e aquelas que adquiriram dimensões internacionais, em razão da existência de disparidades capazes de sustentar a concorrência saudável neste âmbito. Ressalta-se também que todos os sistemas bancários da região passaram por crises recentes, que, sem terem sido objeto de intervenção eficiente no âmbito do bloco pelas instituições competentes, somadas às discrepâncias econômicas entre os Estados-partes, acabaram por resultar em ritmos diferentes de superação desses problemas (STUDART; HERMANN, 2001, p. 114).

Levanta-se ainda o problema referente ao volume significativo de passivos em outra moeda que não a de seus bancos centrais presente no sistema financeiro dos Estados do Mercosul, o que, dentre outros fatores, como a fragilidade de suas moedas no mercado financeiro internacional, acarretaria 
a manutenção do constante risco de crises cambiais e financeiras (STUDART; HERMANN, 2001, p. 114). Aponta-se aqui também como solução a regulação e negociação como vias para evitar que movimentos de capital intensos e de decisão unilateral venham a desestabilizar ainda mais as economias do bloco. Acredita-se que o avanço da integração intrabloco viria a beneficiar o crescimento dessas economias, reforçando assim o processo de integração financeira entre suas instituições.

Para Dorrucci (DORRUCCI; FIRPO; FRATZSCHER; MONGELLI, 2002, p. 9), os baixos índices de integração constatados poderiam ser atribuídos, dentre outros fatores, ao fato de o Mercosul ter optado pela forma intergovernamental, e não pela supranacional, como fez a União Europeia. De um modo geral, adotando-se uma linha de raciocínio de cunho econômico, como propõem Chagas e Baumann (2007, p. 97), argumenta-se ser fundamental que os agentes políticos, no estudo das alternativas disponíveis, procedam à avaliação dos custos e benefícios que cada uma das alternativas será capaz de aportar. Para o autor, a criação de um banco central independente proporcionaria maior credibilidade da política monetária e redução dos custos de transação, o que impulsionaria o comércio e aumentaria a eficiência microeconômica.

Nesse mesmo sentido, ensina Fanelli (2008, p. 36), que uma opção natural para o Mercosul seria a da criação de um banco ou de uma agência de financiamento regional, apontando que, em face das atividades desempenhadas pelo CAF, por exemplo, seria surpreendente que o Mercosul não contasse com tal estrutura. Argumenta que a constituição de um fundo comum entre os Estados-partes reduziria os custos de transação políticos, pois estar-se-ia estabelecendo uma 
garantia solidária sobre o uso de reservas por qualquer de seus Estados. Esta estrutura, contudo, exigiria também uma convergência regulamentar e de supervisão para a manutenção e o correto funcionamento do sistema. Afirma o autor que tal recurso constituiria um passo inicial para o aprofundamento da integração.

Em que pese haja no Mercosul uma tendência à formação de uma regulação harmônica do setor bancário, como pode se depreender a partir da adesão às normas de Basileia, com vistas à sua implementação e adoção de medidas anticrise, o bloco tem ainda muito o que progredir no assunto. Uma das grandes lacunas existentes consiste na carência de um sistema de regulamentação bancária prudencial (CHEGAS; BAUMANN, 2007, p. 111), o que, como foi visto, consistiu justamente o ponto de enfraquecimento do sistema bancário europeu. Naquele bloco, a falta de transparência, resultante na assimetria de informação entre as instituições financeiras, gerou a crise de dimensões transcontinentais a que atualmente se assiste. A existência de mecanismos de controle e de supervisão do risco das instituições bancárias é ferramenta fundamental para a manutenção da estabilidade financeira de qualquer economia (CHEGAS; BAUMANN, 2007, p. 111).

A solução que para Macedo e Grandes (2005, p. 169) seria o estabelecimento de uma governança comum entre os Estados do Mercosul, com vistas à intensificação da integração e norteada pelos progressos obtidos relativamente à estabilidade macroeconômica e à reforma regulatória. Para os autores, um sistema de integração flexível seria uma forma de planejar esta governança, aprimorando, assim, as formas de acompanhamento do processo para supervisão. Esta governança deverá, contudo, ser lenta e gradual, a fim de 
possibilitar o estabelecimento da concorrência leal e a construção de uma regulação efetiva.

Entretanto, diante da análise a que se procedeu no presente estudo, as dificuldades que se apresentam ao Mercosul são grandes para a consolidação de tal projeto, dada a ausência de uma verdadeira reputação financeira, como no caso da União Europeia, nem mesmo em seus membros mais fortes e articulados (Brasil e Argentina). Tentou-se dar aplicabilidade no âmbito do Mercosul a um modelo inspirado no europeu, o que, no entanto, falhou justamente em razão da ausência de transparência de informação e da presença de um controle mais efetivo das instituições bancárias em nível da União.

Coincidentemente, trata-se exatamente do que parece ter sido identificado na ausência de uma autoridade comum, capaz de garantir o efetivo cumprimento dos padrões previstos pelo quadro adotado, e a cooperação entre os Estados para o fornecimento e o acompanhamento desse processo. O Mercosul carece ainda de unidade e de comunhão de esforços para tanto, pois a vontade política dos governantes parece não caminhar no mesmo sentido que o processo de integração do bloco (POSTIGA, 2011, 3o capítulo).

Na ótica de Roberto Rebouzas (REBOUZAS, 2009), a crise financeira que acomete a Europa chegou ao Mercosul em um contexto de paralização das instituições e do processo de integração. Afirma que os processos para a consolidação da União Aduaneira, prevista como etapa de transição pelo Tratado de Assunção, estão estancados, assim como as propostas de reforma em áreas cruciais. Para o autor, as instituições regionais dispõem de poucos instrumentos 
coletivos de política, e alerta que, diante da crise, é possível que venham a se debilitar ainda mais.

A título ilustrativo de suas constatações, menciona que os acordos e esforços de cooperação firmados em resposta à crise não passaram de diálogos bilaterais, não chegando a alcançar o nível regional de uma ação conjunta, sem a participação das instituições responsáveis pelo processo de integração. Ressalta, por ultimo, que a fragilidade da resposta institucional por parte do Mercosul também se refletiria na ausência de iniciativas de articulação de posições comuns para participação de foros internacionais, invocando a ausência de menção ao tema entre os chefes de Estado dos Estados-partes do Mercosul à ocasião dos recentes encontros do Conselho do Mercado Comum.

Na visão do autor, ainda que o Mercosul não dispusesse dos instrumentos necessários, não estando, portanto, apto a dar uma resposta efetiva para a crise, poderia ao menos desempenhar sua função de intuito harmonizador dentro do bloco, disciplinando as respostas nacionais e impedindo que ocorra fragmentação ainda maior dos mercados em seu âmbito. Não estando as instituições regionais preparadas a este propósito, afirma ser bem possível que estas sofram as consequências da crise (REBOUZAS, 2009).

Há estudos mais otimistas (FANELLI, 2008, p. 33), que apontam para o delineamento de uma estratégia futura para a integração financeira no Mercosul. Não obstante os entraves políticos e econômicos que se colocam à implementação de tais mudanças, figurando dentre estas a criação de um instituto para cooperação financeira, iniciativas para harmonização da normativa para aprimoramento das práticas e dos códigos 
no Mercosul, assim como marcos institucionais orientados a melhorar o manejo de reservas e de fundos para o desenvolvimento são encarados como alternativas viáveis para a integração do sistema financeiro (FANELLI, 2008, p. 33).

Entretanto, ainda que condições mais favoráveis do ponto de vista financeiro e macroeconômico tenham sido recentemente constatadas entre os Estados do bloco, acreditase que a intermediação financeira seja necessária, em razão da baixa integração entre os sistemas nacionais no âmbito do Mercosul. Afirma-se ainda que os Estados-partes não empreendem esforços para utilizar as oportunidades que poderiam existir para o aprofundamento da integração no setor, o que no futuro poderia vir a constituir séria restrição sobre o crescimento e a estabilidade da região, a exemplo do que vem se observando na União Europeia (FANELLI, 2008, p. 33).

Aponta-se aqui um requisito faltante no Mercosul para uma integração mais profunda, afirmando que a região não preencheria as condições para ser considerada uma "área monetária ótima". Nem mesmo a presença dos bancos de um Estado-parte nos demais revela-se significativa no âmbito do bloco. Fatores como a pouca mobilidade de mão de obra, grandes diferenças de renda, pouco comércio intrabloco, ciclo de negócios não coordenados e a ausência de uma moeda que pudesse garantir a credibilidade para uma moeda comum constituem os fatores de integração faltantes no Mercosul para o estabelecimento de um sistema bancário (CHAGAS; BAUMANN, 2007, p. 98). Não obstante, como bem ensina Fanelli, esses obstáculos seriam tão significativos quanto os benefícios que poderiam ser alcançados pelo bloco pela integração de seus sistemas financeiros (FANELLI, 2008, p. 28). 


\section{Considerações Finais}

Da análise a que se procedeu, fica evidenciado o fato de que não se pode querer transpor um modelo pronto, como o europeu, para a integração do setor bancário no âmbito do Mercosul, em razão da existência de importantes características de caráter estrutural e também de nível de desenvolvimento verificado entre os Estados do próprio bloco. Podese, contudo, pensar na adoção de medidas próprias dos estágios iniciais da integração, como os princípios de harmonização mínima.

O que se constata, entretanto, é que, no Mercosul, em que pese a considerável melhora da condição econômica geral do bloco, inexistem iniciativas efetivas no sentido de dar prosseguimento ao processo de integração, seja financeiro, seja geral (FANELLI, 2008, p. 28). A tendência é muito maior, nesse sentido, à adequação isolada das normativas nacionais aos padrões estabelecidos pelas disposições internacionais, como ocorreu com relação à adoção das Normas da Basileia, dos Princípios de Supervisão Bancária Consolidada, entre outros instrumentos internacionais.

A ausência de vontade política dos sócios do Mercosul, seja decorrente da incapacidade de vislumbrar os benefícios que seriam colhidos por meio da integração, seja simplesmente pela falta de credibilidade nesse sistema que nos últimos anos não tem apresentado nenhum tipo de progresso quando se fala na atuação conjunta do bloco, permanece, contudo, como maior obstáculo à integração do bloco, sobretudo no tocante ao setor bancário (FANELLI, 2008, p. 15).

Neste âmbito, identifica-se no máximo a atuação de bancos de desenvolvimento para sustentar o crescimento, 
enquanto que o quadro de harmonização das legislações tendente ao aprofundamento da integração financeira reflete-se insipiente e carente de visibilidade. É paradoxal, contudo, esta situação, uma vez que os sistemas financeiros do Mercosul estariam mais baseados nos bancos do que nos mercados, propriamente ditos, sendo estes últimos mais desenvolvidos no Brasil e na Argentina, apenas (FANELLI, 2008, p. 26, p. 30).

Dentre as alternativas propostas, neste estudo, considerou-se razoável o ponto de vista segundo o qual a criação de um fundo comum entre os países do Mercosul, para financiamento de grandes projetos e investimentos no âmbito do bloco, para que seus sócios pudessem juntos atingir maiores níveis econômicos, seria alternativa capaz de estimular a harmonização da regulação e da supervisão do bloco no setor bancário, nos moldes do modelo planejado para a União Europeia.

Inexiste, contudo, atualmente, no Mercosul, nem mesmo um nível mínimo de uniformidade no setor capaz de sustentar uma atuação conjunta. Por esta razão é que se estuda o pressuposto para o funcionamento de um eventual sistema bancário, consistente na integração financeira, que, apesar de também não apresentar os níveis de convergência necessários, poderiam representar um avanço e um benefício maior para as economias do bloco (FANELLI, 2008, p. 30).

Em conclusão, ressalta-se que o momento de crise, aparentemente agravante da situação que foi observada neste estudo, não teve o mesmo efeito no Mercosul que teve na União Europeia, de provocar uma revisão institucional, permanecendo este, ao contrário, inerte, diante dos problemas apresentados. $\mathrm{O}$ mesmo momento deve servir de 
estímulo para mover a vontade política dos sócios do bloco no sentido de começar a implementar iniciativas de aproximação entre os Estados. A exemplo do que vem sendo defendido majoritariamente a nível europeu, acredita-se que os Estados em uma atuação conjunta estariam mais preparados financeiramente e institucionalmente para a coordenação de ações tanto de caráter preventivo quanto de caráter corretivo.

Nesse bojo, porém, dá-se relevo à importância de que os Estados estejam efetivamente dispostos a serem submetidos à fiscalização necessária e a cooperar para a consolidação de um setor financeiro capaz de fornecer estabilidade e segurança aos Estados e aos seus cidadãos, tornando a integração efetiva dentro dos objetivos para os quais fora idealizada. Em vista do pavor que acomete aos Estados mais necessitados, a linha de ação mais coerente no Mercosul, ainda que a longo prazo, é a de bem fazer o seu "dever de casa", na linha do que afirma a chanceler alemã, manifestando-se acerca do contexto europeu (MERKEL, 2012), de modo a colaborar para o reforço da confiança entre os Estados, substrato para a consolidação da integração real.

\section{Referências}

BANCO CENTRAL DO BRASIL. Disponível em: <http://www.bcb. gov.br/Rex/SGT4/port/SGT4_intro_CSF.asp>. Acesso em: 8 jul. 2012. BANCO CENTRAL DO BRASIL. Boletim Mercosul. Disponível em: <http://www.bcb.gov.br/htms/mercosul/evolucao.asp?idpai=bminfosel>. Acesso em: 8 jul. 2012.

BANCO CENTRAL DO BRASIL. Quadros Comparativos. Disponível em: <http://www.bcb.gov.br/Rex/SGT4/port/SGT4_quadros_ comp_CSF.asp>. Acesso em: 8 jul. 2012. 
BANCO CENTRAL DO BRASIL. Resolução № 4.019, de 29 de setembro de 2011. Disponível em: < http://www.bcb.gov.br/pre/ normativos/res/2011/pdf/res_4019.pdf>. Acesso em: 8 jul. 2012.

BANCO CENTRAL DO BRASIL. Rodada de Negociações - Protocolo de Montevidéu. 2003/2004. Disponível em: <http://www.bcb.gov. br/?SGT4LISTAS>. Acesso em: 8 jul. 2012.

BANK FOR INTERNATIONAL SETTLEMENTS. Basel Committee on Banking Supervision - International Convergence of Capital Measurement and Capital Standards - A revised framework. Basel, 2004. Disponível em: <http://www.bis.org/publ/bcbs107. pdf $>$. Acesso em: 8 jul. 2012.

BANK FOR INTERNATIONAL SETTLEMENTS. International Convergence of Capital Measurement and Capital Standards - A Revised Framework, Bank for International Settlements - BIS, Basiléia. Disponível em: <http://www.bis.org/publ/bcbs107.htm>. Acesso em: 8 jul. 2012.

BANK FOR INTERNATIONAL SETTLEMENTS. Progress Report on Basel III Implementation. Basel, 2012. Disponível em: <http://www. bis.org/publ/bcbs215.pdf>. Acesso em: 8 jul. 2012.

CAMPOS, João Mota de; CAMPOS, João Luiz Mota de. Manual de Direito Comunitário. 4. ed. Coimbra: Coimbra, 2004.

CARNEIRO, Fabio Lacerda; VIVAN, Gilneu Francisco Astolfi; KRAUSE, Kathleen. O novo acordo da Basileia: um estudo de caso para o contexto brasileiro. Resenha BMEFF, São Paulo, n. 63, 2004. Disponível em: <http://www4.bcb.gov.br/pre/inscricaoContaB/ trabalhos/O\%20Novo\%20Acordo $\% 20$ de $\% 20$ Basil\%C3\%A9ia um $\% 20$ estudo $\% 20$ de $\% 20$ caso $\% 20$ para $\% 200 \% 20$ contexto $\% 20$ brasileiro.pdf>. Acesso em: 8 jul. 2012.

CHAGAS, Leonardo; BAUMANN, Renato. Integração monetária no Mercosul: ganhos com menores custos de transação? Economia Aplicada, São Paulo, v. 11, n. 1, p. 95-111, 2007.

CONSELHO DO MERCADO COMUM. MERCOSUL/CMC/DEC. № 10/93. Disponível em: <http://www.bcb.gov.br/Rex/SGT4/Ftp/ DEC_10_1993.pdf>. Acesso em: 8 jul. 2012. 
Regulação da Prestação de Serviços Bancários...

CONSELHO DO MERCADO COMUM. MERCOSUL/CMC/DEC. № 12/94. Disponível em: <http://www.bcb.gov.br/Rex/SGT4/Ftp/ DEC_12_1994.pdf>. Acesso em: 8 jul. 2012.

COORDENAÇÃO NACIONAL. XXXIII REUNIÃO ORDINÁRIA DO SUBGRUPO DE TRABALHO N. 4 - "ASSUNTOS FINANCEIROS". MERCOSUR/SGT N.4/ACTA N. 01/2012. Argentina, 2012.

DORRUCCI, Ettore; FIRPO, Stefano; FRATZSCHER, Marcel; MONGELLI, Francesco Paolo. European Integration: what lessons for other regions? The case of Latin America. ECB Working Paper no 185, 2002. Disponível em: <http://www.ecb.europa.eu/pub/pdf/ scpwps/ecbwp185.pdf>. Acesso em: 8 jul. 2012.

FANELLI, José María (Org.). Mercosur: integracion y profundizacion de los mercados financieros. Montevidéo: Red Mercosur de Investigaciones Económicas, 2008.

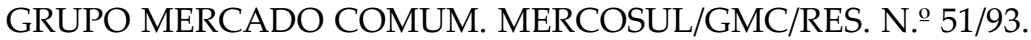
Disponível em: <http://www.mercosur.int/msweb/Normas/normas _web/Resoluciones/PT/GMC_RES_1993-051_PT_ProjetoDecis\%C3\%A3o.PDF>. Acesso em: 8 jul. $20 \overline{1} 2$.

GRUPO MERCADO COMUM. MERCOSUL/GMC/RES. N. 20/95. Disponível em: <http://www.bcb.gov.br/rex/sgt4/Ftp/CD\%20Fluxograma/Resolu\%C3\%A7\%C3\%B5es\%20Mercosul/GMC_1995_ RES_020.pdf $>$. Acesso em: 8 jul. 2012.

GRUPO MERCADO COMUM. MERCOSUL/GMC/RES. N. 이잉. Disponível em: <http://www.bcb.gov.br/rex/sgt4/ftp/res_20_2001. pdf>. Acesso em: 8 jul. 2012.

HELLWIG, Martin F. Systemic risk in the financial sector: an analysis of the subprime-mortgage financial crisis. The Economist, v. 157, n. 2, 2009.

LOBO, Maria Tereza de Cárcomo. Manual de Direito Comunitário: a Ordem Jurídica da União Europeia. Curitiba: Juruá, 2004.

LORENTZ, Adriane Cláudia Melo. Supranacionalidade no Mercosul: A Doutrina, os Governos, a Constituição Federal e os Tratados de Integração. Curitiba: Juruá, 2001.

MACEDO, Jorge Braga; GRANDES, Martin. Argentina and Brazil Risk: A "Eurocentric" Tale. Monetary Policy and Macroeconomic Stabilization in Latin America, 2005. p. 154-172. 
MENDONÇA, Ana Rosa Ribeiro de. Sistemas financeiros no Mercosul: estrutura, financiamento de longo prazo e interpenetração de capitais. Estudos Transversais: Perspectivas do Investimento na Dimensão do Mercosul e da América Latina. Campinas: IE/Unicamp, 2009.

MERCOSUL. Tratado de Assunção. 26.3.1991. Disponível em: <http://www.mercosul.gov.br/tratados-e-protocolos/tratado-de-assuncao-1>. Acesso em: 8 jul. 2012.

MERKEL, Angela. Discurso proferido na Academia Chinesa de Ciências Sociais, em Pequim, no dia 2 de fevereiro de 2012. Disponivel em: <http://www.advivo.com.br/blog/luisnassif/a-europaesta-crescendo-unida-na-crise-diz-merkel>. Acesso em: 8 jul. 2012.

PALOMO, Ricardo; SANCHIS-PALACIO, Joan Ramón; GUTIÉRREZFERNÁNDEZ, Milagros. Efectos de la crisis financera sobre la innovación em la reorganización de los sistemas bancários: los sistemas institucionales de protección em las entidades financeras de ámbito territorial. Revista Innovar, v. 21, n. 39, p. 179-190, jan./mar. 2011.

POSTIGA, Andréa Rocha. A análise da supranacionalidade e da intergovernabilidade como modelos de integração regional na busca do desenvolvimento econômico e social. 2011. Trabalho de Conclusão de Curso (Graduação em Ciências Jurídicas e Sociais - Direito) Pontifícia Universidade Católica do Rio Grande do Sul, Porto Alegre, 2011.

REBOUZAS, Roberto. Respuestas a la crisis y niveles de gobernanza: ¿global, regional o nacional? Observatorio Economico, 2009. Disponível em: <http://oered.org/index.php?option=com_content\&view $=$ article\&id $=42 \% 3$ Arespuestas-a-la-crisis-y-niveles-degobernanza-iglobal-regional-o-nacional\&catid=1\%3Aarticulos\&Itemid=3\&lang=en>. Acesso em: 8 jul. 2012.

SGT-4 SUBGRUPO DE TRABALHO N․․ 4 - ASSUNTOS FINANCEIROS. VI RODADA DE NEGOCIAÇÕES - PROTOCOLO DE MONTEVIDEO. Disponível em: <http://www.bcb.gov.br/rex/SGT4 /Ftp/list_brasil_r6.pdf $>$. Acesso em: 8 jul. 2012.

SGT-4 SUBGRUPO DE TRABALHO N.. 4 - ASSUNTOS FINANCEIROS. COORDENAÇÃO NACIONAL. XXXIII REUNIÃO ORDINÁRIA DO SUBGRUPO DE TRABALHO N. 4 - "ASSUNTOS FINANCEIROS". MERCOSUR/SGT N.ㄴ/ACTA N.. 01/2012. Argentina, 2012. 
Regulação da Prestação de Serviços Bancários...

STUDART, Rogério; HERMANN, Jennifer. Estrutura e Operação dos Sistemas Financeiros no MERCOSUL: Perspectivas a partir das Reformas Institucionais de 1990. IPEA: Brasília, 2001. 144 p. Disponível em: <http://www.ipea.gov.br/pub/td/2001/td_0799.pdf>. Acesso em: 8 jul. 2012.

VIGEVANI, Tullo; FAVARON, Gustavo de Mauro; JÚNIOR, Haroldo Ramanzini; CORREIA, Rodrigo Alves. O papel da integração regional para o Brasil: universalismo, soberania e percepção das elites. Revista Brasileira de Política Internacional, Brasília, v. 51, n. 1, p. 5-27, jul./dez. 2008.

Submissão: $16 / 11 / 2012$

Aceito para Publicação: 14/08/2013 

Nesta obra foram utilizadas as fontes Palatino Linotype e Myriad Pro.

Capa em papel supremo 250g.

Páginas internas em papel offset $75 \mathrm{~g}$.

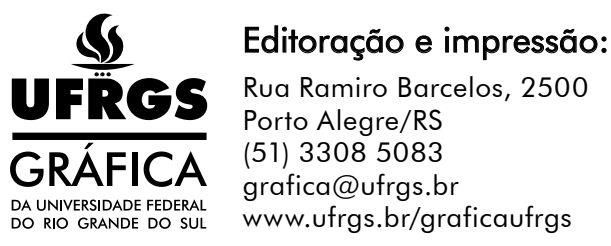

2014 - Realização: Núcleo de Criação, Editoração, Revisão e Web da Gráfica da UFRGS 